THAIS FERREIRA PAMPLONA

Efeito da adição de ácido polifosfórico em ligantes asfálticos de diferentes fontes 



\section{Efeito da adição de ácido polifosfórico em ligantes asfálticos de diferentes fontes}

Dissertação apresentada ao Departamento de Engenharia de Transportes da Escola de Engenharia de São Carlos, da Universidade de São Paulo, como parte dos requisitos para obtenção do título de Mestre em Engenharia Civil

Área de Concentração: Infraestrutura de Transportes Orientador: Prof. Dr. Adalberto Leandro Faxina

São Carlos

Fevereiro

2013 
AUTORIZO A REPRODUCAO TOTAL OU PARCIAL RESTE TRABALHO, DE ESTUDO E PESQUISA, DESDE QUE CITADA A FONTE.

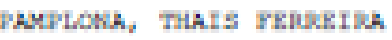

Efeito da adiça de deldo polifasarico en 1iqantea asfalefees de diferentes fontes / Thars reaketha

PReplowh; arientader Draf. Adelberto Inandro Faxina. sac Carlea, 2013.

Disaertaça (Mestrado) - Drograma de Nua-Graduaça en Engenharia de Tranapartes a Arwa de Cancentraça wr Infra-Estrutura de Iransporte m- Racola de Kncknherto de sao Carlos da Unfversidade de Sao Daule, 2013.

1. Ligante asfalefeo. 2. Mnolegia. 3. Grau de desemperiho. 4. Ensalo Meci. 5. Ensalo laks. I. Titulo. 
Candidata: Engenheira THAIS FERREIRA PAMPLONA.

Título da dissertaçăo: "Efeito da adiçầ de ácido polifoalórico em ligantes asfílticos de diferentes fontes",

Data da defosa: $25 / 00 / 2013$

\section{Comigsăo Iulgadora: .}

Prot. De. Adalberto Leandro Faxina (Orientador)

(Escola de Engenharia de Sào Carlos/EESC)

Prof. Dr. Hussain U: Bahia

(Universidade de Wisconsin/USA)

Profi. Dret. Sandra de Aguiar Soares

(Uniwersidade Federal do Ceard/UFC)
Resultado:

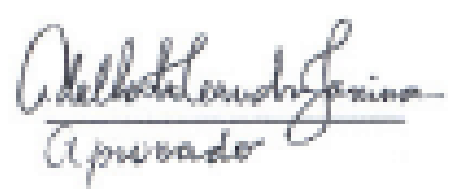

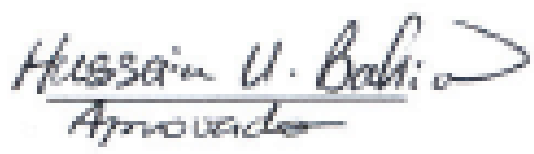

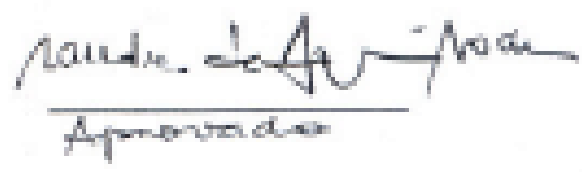

Coordcnador do Programa de Pós-Graduaçāo em Engenharia de Transportes:

Prof. Associado Antônio Nélson Rodrigues da Silva

Presidente da Comissīo de Pós-Graduaçáo:

Prof. Titular Denis Vinicius Coury 
DEDICATÓRIA

Aos meus pais Paulo e Neidinha por todo amor incondicional e apoiarem todos os meus sonhos

DEDICO. 


\section{AGRADECIMENTOS}

Aos meus pais, pelo amor incondicional, por todo o incentivo à minha formação e por acreditarem nos meus sonhos.

Aos meus irmãos Ivo e Bruno por estarem sempre ao meu lado me fortalecendo, por todo carinho e amizade.

Ao professor Adalberto Leandro Faxina, pela orientação, apoio, amizade, confiança e pelas incontáveis intervenções valiosas.

À professora Sandra Soares, por toda a atenção, dedicação e orientação durante esse trabalho e na minha formação acadêmica.

Ao professor Hussain U. Bahia pela atenção, por possibilitar a realização de alguns ensaios e pelas valiosas sugestões.

À CAPES, pela bolsa concedida

Aos professores e funcionários do Departamento de Transporte da Escola de Engenharia de São Carlos.

As minhas amigas irmãs Andrea, Cristina, Juliana e Mariana por mais de 15 anos de amizade, por todos os sonhos que sonhamos juntas e por estarem sempre ao meu lado mesmo que distantes.

As amigas Camila e Cecília por esses anos de convivência, pela amizade, apoio e por tornarem meu dia-a-dia mais prazeroso.

Aos amigos de São Carlos, em especial a Camila, Cecília, Felipe, Jéssica e Suzana pela amizade, todos os bons momentos e por tornarem essa fase da minha vida mais suave. 


\section{SUMÁRIO}

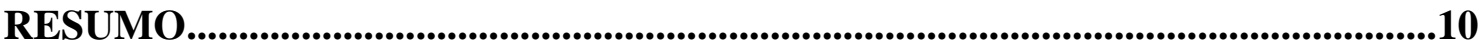

ABSTRACT ……...................................................................................................11

CAPÍTULO 1. INTRODUÇÃO .................................................................25

1.1 DEFINIÇÃO E RELEVÂNCIA DO TEMA ………………….....................25

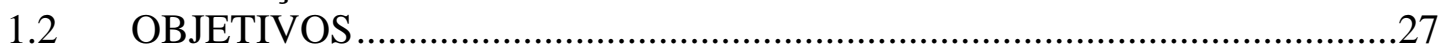

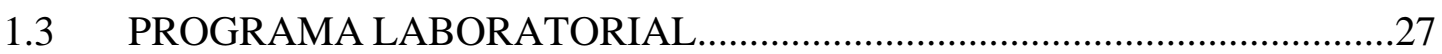

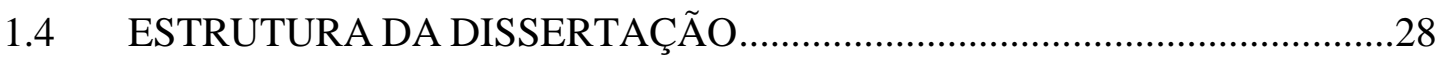

CAPÍTULO 2. REVISÃO BIBLIOGRÁFICA ................................................29

2.1 LIGANTE ASFÁLTICO E SUA COMPOSIÇÃO QUÍMICA..........................29

2.2 ADIÇÃO DE ÁCIDO POLIFOSFÓRICO AO LIGANTE ASFÁLTICO........34

CAPÍTULO 3. MATERIAIS E MÉTODOS...................................................53

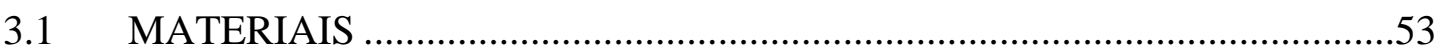

3.1.1 Preparo das amostras......................................................................53

3.2 PROCEDIMENTOS DE ENVELHECIMENTO …………………….........54

3.2.1 Envelhecimento termo-oxidativo em estufa de filme rotativo (RTFOT) .....54

3.2.2 Envelhecimento termo-oxidativo em sistema de vaso de pressão $(P A V)$....54

3.3 REÔMETRO DE CISALHAMENTO DINÂMICO $(D S R) \ldots \ldots \ldots \ldots . . . . . . . . . . . . . . . . . .55$

3.4 MÉTODOS DE ENSAIO ……………………………………………......57

3.4.1 Cromatografia de camada fina com detecção por ionização de chama ......57

3.4.2 Determinação da viscosidade rotacional e da temperatura de compactação e

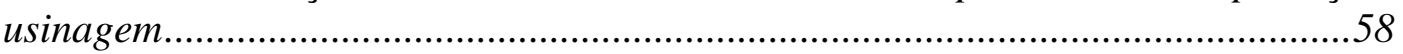

3.4.3 Varredura de frequência ....................................................................59

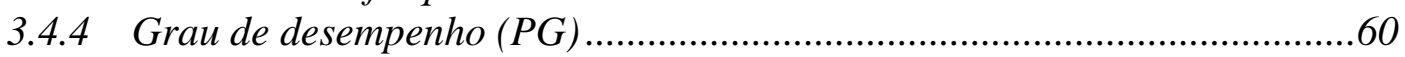

3.4.5 Multiple Stress Creep and Recovery (MSCR) ........................................60

3.4.6 Linear Amplitude Sweep (LAS) ............................................................60

CAPÍTULO 4. CARACTERIZAÇÃO QUÍMICA, GRAU DE DESEMPENHO, RIGIDEZ E ELASTICIDADE DOS LIGANTES ASFÁLTICOS ..............................61

4.1 ANÁLISE DE RESULTADOS .......................................................................61

4.1.1 Cromatografia de camada fina com deteç̧ão por ionização de chama.....61

4.1.2 Grau de Desempenho ........................................................................63

4.1.3 Viscosidade ........................................................................................66

4.1.4 Temperatura de usinagem e compactação …………………………….......67

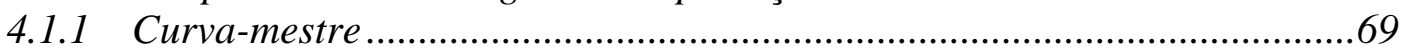

CAPÍTULO 5. ENSAIO DE FLUÊNCIA E RECUPERAÇÃO SOB TENSÕES

MÚLTIPLAS (MSCR) ..................................................................................97

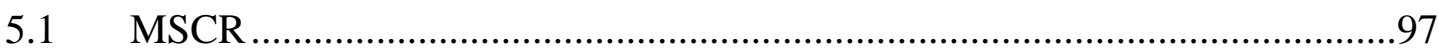

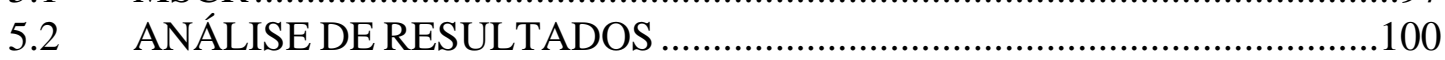

5.2.1 Análise de resultados considerando o grau de desempenho do ligante asfáltico 100

5.2.2 Análise de resultados considerando a temperatura do pavimento ............103

5.2.1 Classificação do nível de tráfego ............................................................116

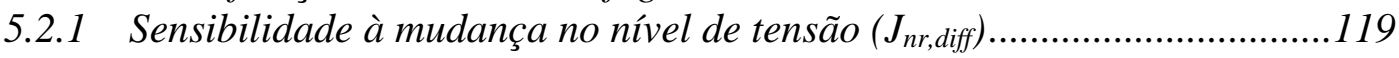

CAPÍTULO 6. FADIGA EM LIGANTES ASFÁLTICOS..................................121

6.1 INTRODUÇÃO DE FADIGA EM LIGANTES ASFÁLTICOS ...................121

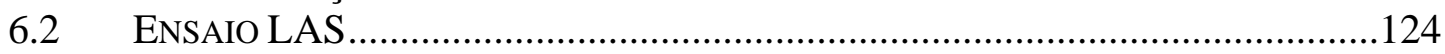




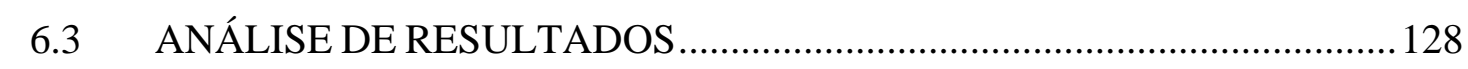

CAPÍTULO 7. CONCLUSÕES E SUGESTÕES DE PESQUISA ...................... 151

REFERÊNCIAS BIBLIOGRÁFICAS ...................................................................... 163 


\section{RESUMO}

PAMPLONA, T. F. Efeito da adição de ácido polifosfórico em ligantes asfálticos de diferentes fontes. 2013. Dissertação (Mestrado) - Escola de engenharia de São Carlos, Universidade de São Paulo, São Carlos, 2013

Aditivos têm sido incorporados ao ligante asfáltico no intuito de melhorar o desempenho dos pavimentos. O enrijecimento do ligante asfáltico provocado pelos aditivos, aumenta a resistência à deformação permanente das misturas asfálticas, mas ainda não se sabe qual o efeito deles sobre a resistência à fadiga e ao trincamento térmico dos ligantes asfálticos. Um dos produtos modernos mais promissores para modificação de ligantes asfálticos é o ácido polifosfórico (PPA). No entanto, o mecanismo de modificação com PPA depende fortemente da composição química do ligante asfáltico de base. Para avaliar o impacto da adição de PPA em ligantes asfálticos de diferentes fontes, dois ligantes asfálticos 50/70 (REDUC e LUBNOR), de diferentes PGs e composição química foram modificados por quatro proporções de PPA $(0,5,1,0,1,5,2,0 \%)$. As frações de saturados, aromáticos, resinas e asfaltenos (SARA) dos ligantes asfálticos puros e modificados foram determinadas por meio da cromatografia de camada fina. Para avaliar o efeito da adição de PPA sobre as propriedades reológicas dos ligantes asfálticos, foram analisados a viscosidade, o grau de desempenho, a rigidez, a elasticidade, a recuperação elástica, a compliância não-recuperável e o comprimento de trinca na ruptura. A viscosidade dos ligantes asfálticos e as temperaturas de usinagem e compactação aumentaram com o aumento do teor de PPA. A temperatura alta do PG aumentou com a proporção de PPA em intensidades diferentes, dependendo do ligante asfáltico de base. A adição de PPA aumenta a rigidez, a elasticidade e a recuperação elástica e diminui a compliância não-recuperável dos ligantes asfálticos. Em termos de tolerância à fadiga, a adição de PPA e o envelhecimento provocaram um aumento na tolerância à fadiga dos ligantes asfálticos. Os resultados apresentados destacam a importância da composição química do ligante asfáltico de base no grau de modificação provocado pela adição de PPA. Recomenda-se a adição de teores baixos de PPA para o LUBNOR (até 1\%) e de teores altos de PPA para o REDUC (superiores a 1,0\%).

Palavras-chave: Ligante asfáltico. Ácido polifosfórico. Reologia. Grau de desempenho. Ensaio MSCR. Ensaio LAS. 


\section{ABSTRACT}

PAMPLONA, T. F. Effect of polyphosphoric acid on asphalt binders from different crude sources. 2013. Dissertação (Mestrado) - Escola de engenharia de São Carlos, Universidade de São Paulo, São Carlos, 2013

Additives have been incorporated to asphalt binder in order to improve the performance of pavements. The stiffening of asphalt binders induced by additives should increases the rut resistance of asphalt concrete, unclear how PPA affects the resistance to fatigue and thermal cracking of asphalt binders. One of the most promising new products for asphalt binders modification is the polyphosphoric acid (PPA). However, the mechanism of PPA modification depends strongly on the chemical composition of the base asphalt binder. To evaluate the impact of the PPA modification in asphalt binders from different sources, two asphalt binders 50/70 penetration grade (REDUC and LUBNOR) from different crude source with different performance grades and chemical composition have been modified by four proportions of PPA $(0.5,10,1.5,2.0 \%)$. Saturated aromatics, resins and asphaltenes (SARA) fractions of neat and modified asphalt binders were determined using the thin-layer chromatography. To evaluate the effect of PPA addition on the rheological properties of asphalt binders it was analyzed the viscosity, the performance grade, the stiffness, the elasticity, the elastic recovery, the non-recoverable compliance and the crack length at failure. The viscosity of asphalt binders and the mixing and compaction temperature increased with increasing levels of PPA. The high temperature of PG increased in different magnitude with the ratio of PPA, depending on the base asphalt binder. The addition of PPA increases the stifiness, the elasticity and the elastic recovery and decrease the non-recoverable compliance of asphalt binders. With regard to the fatigue tolerance, the addition of PPA and the thermooxidative aging induced an increase in the fatigue tolerance of asphalt binders. The presented results show the importance of the chemical composition of the base asphalt binder on the extent of modification caused by the addition of PPA. It is recommended to use low levels of PPA to modify the LUBNOR (to 1\%) and high levels of PPA to modify the REDUC (over $1.0 \%)$

Key-words: Asphalt binder. Polyphosphoric acid. Reology. Performance grade. MSCR test. LAS test.

\section{LISTA DE TABELAS}


Tabela 2.1 - Propriedades dos ligantes asfálticos puros e modificados (FILIPPIS et al., 1995)

Tabela 2.2 - Comparação dos resultados de amostra de ligante asfáltico com e sem tratamento com ácido polifosfórico (LEITE et al., 2004) ....

Tabela 2.3 - Valores de ponto de amolecimento, penetração e viscosidade para os ligantes puro e modificados com PPA (CAO et al., 2011)

Tabela 2.4 - Procedimento experimental e teores dos modificadores SBS e PPA (MALDONADO et al., 2012) .48

Tabela 2.5 - Procedimento experimental desenvolvido para avaliar o efeito da redução de polímero na resistência à fadiga de misturas asfálticas (MALDONADO et al., 2012) ..48

Tabela 2.6 - Resultados do ensaio Lotman modificado (FERNANDES, 2011) .51

Tabela 3.1- Formulação e PG dos ligantes asfálticos 54

Tabela 4.1 - Composição química dos ligantes asfálticos puros e modificados com PPA62

Tabela 4.2 - Índice de instabilidade coloidal dos ligantes asfálticos puros e modificados com PPA. .62

Tabela 4.3 - Quantidade de PPA necessária para aumentar o PG nas temperaturas altas65

Tabela 4.4 - Viscosidades do LUBNOR e do REDUC puro e modificados em função de temperatura

Tabela 4.5 - Temperatura de usinagem e compactação dos ligantes asfálticos puros e modificados .68

Tabela 4.6 - Variações dos valores de $\mathrm{G}^{*}$ para o LUBNOR puro e modificados com PPA, a $25^{\circ} \mathrm{C}$, na condição virgem

Tabela 4.7 - Variações dos valores de $\mathrm{G}^{*}$ para o REDUC puro e modificados com PPA, a $25^{\circ} \mathrm{C}$, na condição virgem. .87

Tabela 4.8 - Variações dos valores de $\mathrm{G}^{*}$ para o LUBNOR puro e modificados com PPA, a $25^{\circ} \mathrm{C}$, envelhecido no RTFOT .88

Tabela 4.9 - Variações dos valores de $\mathrm{G}^{*}$ para o REDUC puro e modificados com PPA, a $25^{\circ} \mathrm{C}$, envelhecido no RTFOT .

Tabela 4.10 - Variações dos valores de $\mathrm{G}^{*}$ para o LUBNOR puro e modificados com PPA, a $25^{\circ} \mathrm{C}$, envelhecido no PAV 
Tabela 4.11 - Variações dos valores de G* para o REDUC puro e modificados com PPA, a $25^{\circ} \mathrm{C}$, envelhecido no PAV

Tabela 4.12 - Variações dos valores de $\mathrm{G}^{*}$ para o LUBNOR puro e modificados , a $25^{\circ} \mathrm{C}$, em função do envelhecimento

Tabela 4.13 - Variações dos valores de $\mathrm{G}^{*}$ para o REDUC puro e modificados , a $25^{\circ} \mathrm{C}$, em função do envelhecimento

Tabela 4.14 - Variações dos valores de G*/sen $\delta$ para o LUBNOR e o REDUC puros e modificados, a $10 \mathrm{rad} / \mathrm{s}$, envelhecidos no RTFOT, em função da temperatura

Tabela 4.15 - Variações dos valores de $G^{*}$.sen $\delta$ para o LUBNOR e o REDUC puros e modificados, a $10 \mathrm{rad} / \mathrm{s}$, envelhecidos no PAV, em função da temperatura 95

Tabela 5.1 - Classificação quanto ao valor de Jnr (AASHTO M320) 99

Tabela 5.2 - Valores de percentual de recuperação recomendado pelo FHWA (D’ANGELO, 2010) 99

Tabela 5.3 - Variações dos valores de \%R, a 100Pa, para o REDUC e LUBNOR em função da temperatura 109

Tabela 5.4 - Variações dos valores de \%R, a 3.200Pa, para o REDUC e LUBNOR em função da temperatura 109

Tabela 5.5 - Teores mínimos de PPA para obter a recuperação elástica mínima de 30\%109

Tabela 5.6 - Variações dos valores de Jnr, a 100Pa, para o REDUC e LUBNOR em função da temperatura.

Tabela 5.7 - Variações dos valores de Jnr, a 3.200Pa, para o REDUC e LUBNOR em função da temperatura 115

Tabela 5.8 - Teores mínimos de PPA para obter a compliância não-recuperável máxima de $2 \mathrm{kPa}-1$

Tabela 5.9 - Classificação do nível de tráfego dos ligantes asfálticos quanto ao valor do Jnr

Tabela 5.10 - Jnr,diff do LUBNOR puro e modificados com PPA

Tabela 5.11 - Jnr,diff do REDUC puro e modificados com PPA

Tabela 6.1 - Comprimento da trinca na ruptura (af) para todos os ligantes asfálticos. 132

Tabela 6.2 - Parâmetro A35 para todos os ligantes asfálticos.....

Tabela 6.3 - Parâmetro B para todos os ligantes asfálticos 


\section{LISTA DE FIGURAS}

Figura 2.1- Esquema da separação química do ligante asfáltico (CORBETT, 1969) ....30

Figura 2.2 - Influência da origem na composição química SHULGA et al., (2012)......31

Figura 2.3 - Fração SARA para vários ligantes asfálticos antes e após 85 min e 340 min no envelhecimento no RTFOT (LESUEUR, 2009) 32

Figura 2.4 - Representação esquemática de ligantes do tipo SOL e GEL (adaptado de SHELL, 2003). 33

Figura 2.5 - Mecanismo hipotético de ação proposto para a reação entre o ácido polifosfórico e o ligante asfáltico (ORANGE et al., 2004). 36

Figura 2.6 - Reação de fosforilação do PPA com ligante asfáltico (BAUMGARDNER et al., 2005) 37

Figura 2.7 - Reações secundárias do PPA com o ligante asfáltico (Baumgardner et al., 2005) 37

Figura 2.8 - Efeito do PPA no grau de desempenho (FEE et al., 2010) .39

Figura 2.9 - Efeito da adição de PPA na temperatura alta do grau de desempenho de ligantes asfálticos de diferentes fontes (D'ANGELO, 2012)

Figura 2.10 - Variações na temperatura alta do PG em função do teor de PPA para diferentes tipos de ligantes asfálticos (D’ANGELO, 2012). 40

Figura 2.11 - Variação do parâmetro $\mathrm{G}^{*} / \operatorname{sen} \delta$ em função da adição de PPA para ligantes asfálticos de diferentes fontes (SHULGA et al., 2012) 41

Figura 2.12 - Curva mestre do $\mathrm{G}^{*}$ em função da frequência de carregamento dos ligantes asfálticos puros e modificados (FERNANDES, 2011)

Figura 2.13 - Curva mestra da tan $\square$ em função da frequência de carregamento dos ligantes asfálticos puros e modificados (FERNANDES, 2011)

Figura 2.14 - Resultados da (a) penetração e do (b) ponto de amolecimento dos ligantes asfálticos puros e modificados (FERNANDES, 2011)

Figura 2.15 - Viscosidade em função da temperatura do ligante puro e dos ligantes modificados (FERNANDES, 2011).

Figura 2.16 - Efeito do polímero, do PPA e do agente melhorador de adesividade na compliância não-recuperável dos ligantes asfálticos (FEE et al., 2010) . 
Figura 2.17 - Efeito do polímero, do PPA e do agente melhorador de adesividade no percentual de recuperação dos ligantes asfálticos (FEE et al., 2010).

Figura 2.18 - Resultados de vida de fadiga de misturas asfálticas para amostras de vigas envelhecidas a curto prazo (BENNERT et al., 2012)

Figura 2.19 - Resultados de deformação permanente sob carga repetida RTFOT (BENNERT et al., 2012). 50

Figura 2.20 - Resultados de MSCR, a 3.200Pa, dos ligantes asfálticos envelhecidos no RTFOT (BENNERT et al., 2012)

Figura 2.21 - Absorção de água em mástiques (ARNOLD et al., 2012). 51

Figura 3.1- Representação gráfica do modo de aplicação das tensões ou deformações cisalhantes, dos parâmetros e resultados obtidos com o DSR (BERNUCCI et al., 2007)56

Figura 3.2 - Determinação das temperatura de usinagem e compactação (TUC) 59

Figura 4.1 - Grau contínuo dos ligantes asfálticos puros e modificados com 1,5\% de PPA .64

Figura 4.2 - Grau contínuo dos ligantes asfálticos em função da proporção de PPA ....65

Figura 4.3 - Viscosidade rotacional do LUBNOR puro e modificados com PPA .........66

Figura 4.4 Viscosidade rotacional do REDUC puro e modificados com PPA .67

Figura 4.5 - Variação de $\mathrm{G}^{*}$ em função da frequência para LUBNOR não-envelhecidos, modificados com cinco teores de PPA .70

Figura 4.6 - Variação de $\mathrm{G}^{*}$ em função da frequência para LUBNOR envelhecidos no RTFOT, modificados com cinco teores de PPA

Figura 4.7 - Variação de G* em função da frequência para LUBNOR envelhecidos no PAV, modificados com cinco teores de PPA

Figura 4.8 - Variação de $G^{*}$ em função da frequência para LUBNOR não-envelhecido e envelhecido no RTFOT e PAV

Figura 4.9 - Variação de $\mathrm{G}^{*}$ em função da frequência para LUBNOR, modificados com $0.5 \%$ de PPA, não-envelhecido e envelhecidos no RTFOT e PAV

Figura 4.10 - Variação de $\mathrm{G}^{*}$ em função da frequência para LUBNOR, modificados com 1,0\% de PPA, não-envelhecido e envelhecidos no RTFOT e PAV 73

Figura 4.11 - Variação de $\mathrm{G}^{*}$ em função da frequência para LUBNOR, modificados com $1.5 \%$ de PPA, não-envelhecido e envelhecidos no RTFOT e PAV 
Figura 4.12 - Variação de $G^{*}$ em função da frequência para LUBNOR, modificados com 2,0\% de PPA, não-envelhecido e envelhecidos no RTFOT e PAV

Figura 4.13 - Variação de $G^{*}$ em função da frequência para REDUC não-envelhecidos, modificados com cinco teores de PPA

Figura 4.14 - Variação de $\mathrm{G}^{*}$ em função da frequência para REDUC envelhecidos no RTFOT, modificados com cinco teores de PPA

Figura 4.15 - Variação de $\mathrm{G}^{*}$ em função da frequência para REDUC envelhecidos no PAV, modificados com cinco teores de PPA

Figura 4.16 - Variação de $G^{*}$ em função da frequência para REDUC não-envelhecido e envelhecido no RTFOT e PAV .76

Figura 4.17 - Variação de $\mathrm{G}^{*}$ em função da frequência para REDUC, modificados com $0.5 \%$ de PPA, não-envelhecido e envelhecidos no RTFOT e PAV

Figura 4.18 - Variação de G* em função da frequência para REDUC, modificados com 1.0\% de PPA, não-envelhecido e envelhecidos no RTFOT e PAV

Figura 4.19 - Variação de $\mathrm{G}^{*}$ em função da frequência para REDUC, modificados com 1.5\% de PPA, não-envelhecido e envelhecidos no RTFOT e PAV

Figura 4.20 - Variação de $\mathrm{G}^{*}$ em função da frequência para REDUC, modificados com $2.0 \%$ de PPA, não-envelhecido e envelhecidos no RTFOT e PAV

Figura 4.21 - Variação de $\delta$ em função da frequência para LUBNOR não-envelhecidos, modificados com cinco teores de PPA .78

Figura 4.22 - Variação de $\delta$ em função da frequência para LUBNOR envelhecidos no RTFOT, modificados com cinco teores de PPA

Figura 4.23 - Variação de $\delta$ em função da frequência para LUBNOR envelhecidos no PAV, modificados com cinco teores de PPA

Figura 4.24 - Variação de $\delta$ em função da frequência para LUBNOR não-envelhecido e envelhecidos no RTFOT e PAV.... 80

Figura 4.25 - Variação de $\delta$ em função da frequência para LUBNOR, modificado com $0,5 \%$ de PPA, não-envelhecido e envelhecidos no RTFOT e PAV

Figura 4.26 - Variação de $\delta$ em função da frequência para LUBNOR, modificado com 1,0\% de PPA, não-envelhecido e envelhecidos no RTFOT e PAV

Figura 4.27 - Variação de $\delta$ em função da frequência para LUBNOR, modificado com 1,5\% de PPA, não-envelhecido e envelhecidos no RTFOT e PAV 
Figura 4.28 - Variação de $\delta$ em função da frequência para LUBNOR, modificado com 2,0\% de PPA, não-envelhecido e envelhecidos no RTFOT e PAV

Figura 4.29 - Variação de $\delta$ em função da frequência para REDUC, não-envelhecidos, modificados com cinco teores de PPA

Figura 4.30 - Variação de $\delta$ em função da frequência para REDUC, envelhecidos no RTFOT, modificados com cinco teores de PPA

Figura 4.31 - Variação de $\delta$ em função da frequência para REDUC, envelhecidos no PAV, modificados com cinco teores de PPA

Figura 4.32 - Variação de $\delta$ em função da frequência para REDUC não-envelhecido e envelhecidos no RTFOT e PAV

Figura 4.33 - Variação de $\delta$ em função da frequência para REDUC, modificado com $0,5 \%$ de PPA, não-envelhecido e envelhecidos no RTFOT e PAV.

Figura 4.34 - Variação de $\delta$ em função da frequência para REDUC, modificado com 1,0\% de PPA, não-envelhecido e envelhecidos no RTFOT e PAV

Figura 4.35 - Variação de $\delta$ em função da frequência para REDUC, modificado com 1,5\% de PPA, não-envelhecido e envelhecidos no RTFOT e PAV

Figura 4.36 - Variação de $\delta$ em função da frequência para REDUC, modificado com $2,0 \%$ de PPA, não-envelhecido e envelhecidos no RTFOT e PAV

Figura 5.1 - Percentual de recuperação dos ligantes asfálticos puro e modificados, a 100Pa

Figura 5.2 - Percentual de recuperação dos ligantes asfálticos puro e modificados, a 3.200Pa

Figura 5.3 - Compliância não-recuperável dos ligantes asfálticos puro e modificados, a 100Pa 102

Figura 5.4 - Compliância não-recuperável dos ligantes asfálticos puro e modificados, a $3.200 \mathrm{~Pa}$

Figura 5.5 - Percentual de recuperação a $100 \mathrm{~Pa}$, a $52^{\circ} \mathrm{C}$

Figura 5.6 - Percentual de recuperação a $100 \mathrm{~Pa}$, a $58^{\circ} \mathrm{C}$ 104

Figura 5.7 - Percentual de recuperação a $100 \mathrm{~Pa}$, a $64^{\circ} \mathrm{C}$ 105

Figura 5.8 - Percentual de recuperação a $100 \mathrm{~Pa}$, a $70^{\circ} \mathrm{C}$ 105

Figura 5.9 - Percentual de recuperação a $100 \mathrm{~Pa}$, a $76^{\circ} \mathrm{C}$ 106

Figura 5.10 - Percentual de recuperação a $3.200 \mathrm{~Pa}$, a $52^{\circ} \mathrm{C}$ 106 
Figura 5.11- Percentual de recuperação a $3.200 \mathrm{~Pa}$, a $58^{\circ} \mathrm{C}$

Figura 5.12 - Percentual de recuperação a $3.200 \mathrm{~Pa}$, a $64^{\circ} \mathrm{C}$

Figura 5.13 - Percentual de recuperação a $3.200 \mathrm{~Pa}$, a $70^{\circ} \mathrm{C}$ 108

Figura 5.14 - Percentual de recuperação a $3.200 \mathrm{~Pa}$, a $76^{\circ} \mathrm{C}$ 108

Figura 5.15 - Compliância não-recuperável a 100 Pa, a $52^{\circ} \mathrm{C}$ 110

Figura 5.16 - Compliância não-recuperável a $100 \mathrm{~Pa}$, a $58^{\circ} \mathrm{C}$ 110

Figura 5.17 - Compliância não-recuperável a $100 \mathrm{~Pa}$, a $64^{\circ} \mathrm{C}$ 111

Figura 5.18 - Compliância não-recuperável a $100 \mathrm{~Pa}$, a $70^{\circ} \mathrm{C}$ 111

Figura 5.19 - Compliância não-recuperável a $100 \mathrm{~Pa}$, a $76^{\circ} \mathrm{C}$ 112

Figura 5.20 - Compliância não-recuperável a $3.200 \mathrm{~Pa}$, a $52^{\circ} \mathrm{C}$ 112

Figura 5.21 - Compliância não-recuperável a $3.200 \mathrm{~Pa}$, a $58^{\circ} \mathrm{C}$ 113

Figura 5.22 - Compliância não-recuperável a 3.200 Pa, a $64^{\circ} \mathrm{C}$ 113

Figura 5.23 - Compliância não-recuperável a $3.200 \mathrm{~Pa}$, a $70^{\circ} \mathrm{C}$ 114

Figura 5.24 - Compliância não-recuperável a $3.200 \mathrm{~Pa}$, a 76 $\mathrm{C}$ 114

Figura 5.25 - Grau de desempenho sugerido para ligantes asfálticos por regiões do Brasil (Cunha, 2007). 118

Figura 5.26 - Grau de desempenho sugeridos para ligantes asfálticos por regiões dos Estados Unidos (Asphalt Institute, 2010) 118

Figura 6.1 - Incremento da deformação (em degraus) no ensaio LAS (JOHNSON, 2010)

Figura 6.2 - Modelo de fadiga (JOHNSON, 2010) 125

Figura 6.3 Curva do dano acumulado em função de G*/sen $\delta$ (JOHNSON, 2010) .......126

Figura 6.4 - Incremento linear de deformação no ensaio LAS modificado (HINTZ, 2012)

Figura 6.5 - Correlação entre resultados do LAS modificado e do time sweep (HINTZ, 2012)

Figura 6.6 - Variação do aumento da trinca em função do número de ciclos versus o comprimento da trinca para o LUBNOR envelhecido no PAV, a $25^{\circ} \mathrm{C}$ 128 
Figura 6.7 - Variação do aumento da trinca em função do número de ciclos versus o comprimento da trinca para o LUBNOR envelhecido no RTFOT, a $25^{\circ} \mathrm{C}$

Figura 6.8 - Variação do aumento da trinca em função do número de ciclos versus o comprimento da trinca para o REDUC envelhecido no PAV, a $25^{\circ} \mathrm{C}$

Figura 6.9 - Variação do aumento da trinca em função do número de ciclos versus o comprimento da trinca para o REDUC envelhecido no RTFOT, a $25^{\circ} \mathrm{C}$

Figura 6.10 - Variação do aumento da trinca em função do número de ciclos versus o comprimento da trinca para o LUBNOR envelhecido no PAV, a $35^{\circ} \mathrm{C}$

Figura 6.11 - Variação do aumento da trinca em função do número de ciclos versus o comprimento da trinca para o LUBNOR envelhecido no RTFOT, a $35^{\circ} \mathrm{C}$

Figura 6.12 - Variação do aumento da trinca em função do número de ciclos versus o comprimento da trinca para o REDUC envelhecido no PAV aged, a $35^{\circ} \mathrm{C}$

Figura 6.13 - Variação do aumento da trinca em função do número de ciclos versus o comprimento da trinca para o REDUC envelhecido no RTFOT, a $35^{\circ} \mathrm{C}$

Figura 6.14 - Variação do número de ciclos na ruptura em função da amplitude de deformação para os ligantes asfálticos da LUBNOR envelhecidos no PAV, à $25^{\circ} \mathrm{C} \ldots 134$

Figura 6.15 - Variação do número de ciclos na ruptura em função da amplitude de deformação para os ligantes asfálticos da LUBNOR envelhecidos no RTFOT, à $25^{\circ} \mathrm{C} 135$

Figura 6.16 - Variação do número de ciclos na ruptura em função da amplitude de deformação para os ligantes asfálticos da REDUC envelhecidos no $\mathrm{PAV}$, à $25^{\circ} \mathrm{C} \ldots . . .136$

Figura 6.17 - Variação do número de ciclos na ruptura em função da amplitude de deformação para os ligantes asfálticos da REDUC envelhecidos no RTFOT, à $25^{\circ} \mathrm{C} .136$

Figura 6.18 - Variação do número de ciclos na ruptura em função da amplitude de deformação para os ligantes asfálticos da LUBNOR envelhecidos no PAV, à $35^{\circ} \mathrm{C} \ldots 137$

Figura 6.19 Variação do número de ciclos na ruptura em função da amplitude de deformação para os ligantes asfálticos da LUBNOR envelhecidos no RTFOT, à $35^{\circ} \mathrm{C}$.

Figura 6.20 - Variação do número de ciclos na ruptura em função da amplitude de deformação para os ligantes asfálticos da REDUC envelhecidos no PAV, à $35^{\circ} \mathrm{C}$...... 138

Figura 6.21 - Variação do número de ciclos na ruptura em função da amplitude de deformação para os ligantes asfálticos da REDUC envelhecidos no RTFOT, à $35^{\circ} \mathrm{C} .138$

Figura 6.22 - Efeito do envelhecimento na variação do número de ciclos na ruptura em função da amplitude de deformação para o LUBNOR puro, a $25^{\circ} \mathrm{C}$. 
Figura 6.23 - Efeito do envelhecimento na variação do número de ciclos na ruptura em função da amplitude de deformação para o LUBNOR $+0,5 \%$ PPA, a $25^{\circ} \mathrm{C}$

Figura 6.24 - Efeito do envelhecimento na variação do número de ciclos na ruptura em função da amplitude de deformação para o LUBNOR $+1,0 \%$ PPA, a $25^{\circ} \mathrm{C}$ 140

Figura 6.25 - Efeito do envelhecimento na variação do número de ciclos na ruptura em função da amplitude de deformação para o LUBNOR $+1,5 \%$ PPA, a $25^{\circ} \mathrm{C}$

Figura 6.26 - Efeito do envelhecimento na variação do número de ciclos na ruptura em função da amplitude de deformação para o LUBNOR $+2,0 \% \mathrm{PPA}$, a $25^{\circ} \mathrm{C}$

Figura 6.27 - Efeito do envelhecimento na variação do número de ciclos na ruptura em função da amplitude de deformação para o REDUC puro, a $25^{\circ} \mathrm{C}$.

Figura 6.28 - Efeito do envelhecimento na variação do número de ciclos na ruptura em função da amplitude de deformação para o REDUC + 0,5\% PPA, a $25^{\circ} \mathrm{C}$ 142

Figura 6.29 - Efeito do envelhecimento na variação do número de ciclos na ruptura em função da amplitude de deformação para o REDUC $+1,0 \%$ PPA, a $25^{\circ} \mathrm{C}$

Figura 6.30 - Efeito do envelhecimento na variação do número de ciclos na ruptura em função da amplitude de deformação para o REDUC $+1,5 \%$ PPA, a $25^{\circ} \mathrm{C}$ 143

Figura 6.31 - Efeito do envelhecimento na variação do número de ciclos na ruptura em função da amplitude de deformação para o REDUC $+2,0 \%$ PPA, a $25^{\circ} \mathrm{C}$

Figura 6.32 - Efeito do envelhecimento na variação do número de ciclos na ruptura em função da amplitude de deformação para o Lubnor puro, a $35^{\circ} \mathrm{C}$

Figura 6.33 - Efeito do envelhecimento na variação do número de ciclos na ruptura em função da amplitude de deformação para o Lubnor $+0,5 \% \mathrm{PPA}$, a $35^{\circ} \mathrm{C}$ .145

Figura 6.34- Efeito do envelhecimento na variação do número de ciclos na ruptura em função da amplitude de deformação para o Lubnor $+1,0 \%$ PPA, a $35^{\circ} \mathrm{C}$.

Figura 6.35 - Efeito do envelhecimento na variação do número de ciclos na ruptura em função da amplitude de deformação para o Lubnor $+1,5 \%$ PPA, a $35^{\circ} \mathrm{C}$

Figura 6.36 - Efeito do envelhecimento na variação do número de ciclos na ruptura em função da amplitude de deformação para o Lubnor $+2,0 \%$ PPA, a $35^{\circ} \mathrm{C}$ .146

Figura 6.37 - Efeito do envelhecimento na variação do número de ciclos na ruptura em função da amplitude de deformação para o Reduc puro, a $35^{\circ} \mathrm{C}$.....

Figura 6.38 - Efeito do envelhecimento na variação do número de ciclos na ruptura em função da amplitude de deformação para o Reduc $+0,5 \%$ PPA, a $35^{\circ} \mathrm{C}$. 
Figura 6.39 - Efeito do envelhecimento na variação do número de ciclos na ruptura em função da amplitude de deformação para o Reduc $+1,0 \% \mathrm{PPA}$, a $35^{\circ} \mathrm{C}$ 148

Figura 6.40 - Efeito do envelhecimento na variação do número de ciclos na ruptura em função da amplitude de deformação para o Reduc $+1,5 \%$ PPA, a $35^{\circ} \mathrm{C}$ 148

Figura 6.41 - Efeito do envelhecimento na variação do número de ciclos na ruptura em função da amplitude de deformação para o Reduc $+2,0 \%$ PPA, a $35^{\circ} \mathrm{C}$ 


\section{LISTA DE SIGLAS E SÍMBOLOS}

$\% \mathrm{R}$ - Percentual de recuperação

A - Asfaltenos

$a_{f}-$ Comprimento da trinca na ruptura

ANOVA - Statistical Analysis of One-Way Variance

$\mathrm{Ar}$ - Aromáticos

BBF - Bending Beam Fatigue

BBR - Reômetro de flexão em viga

CAP - Cimento asfáltico de petróleo

CNT - Confederação Nacional do Transporte

$\mathrm{D}(\mathrm{t})$ - Dano acumulado

DSR - Reômetro de cisalhamento dinâmico

E - Extremely heavy

$f$ - Frequência

FHWA - Administração Rodoviária Federal dos Estados Unidos

G* - Módulo complexo

$\mathrm{G}^{*}$.sen $\delta$ - Parâmetro de fadiga Superpave

G*/sen $\delta$ - Parâmetro de deformação permanente Superpave

G' - Módulo de armazenamento

G” - Módulo de perda

$\mathrm{H}$ - Heavy

$\mathrm{I}_{\mathrm{c}}$ - Índice de instabilidade coloidal

$\mathrm{J}_{\mathrm{nr}}$ - Compliância não-recuperável

$\mathrm{J}_{\mathrm{nr}, \text { diff }}$ - Sensibilidade à mudança no nível de tensão

LAS - Linear Amplitude Sweep

LCC - Líquido da castanha de caju

MSCR - Ensaio de fluência e recuperação sob tensão múltipla

NCHRP 9-10 - National Cooperative Highway Research Program

$\mathrm{N}_{\mathrm{f}}$ - Vida de fadiga

PA - Ponto de amolecimento

PAV - Pressure Aging Vessel

PEN - Penetração

PG - Grau de desempenho

PPA - ácido polifosfórico

$\mathrm{R}$ - resinas 
RTFOT - Roling Thin Film Oven Test - RTFOT)

RTRT - Ensaio de fluência repetida e recuperação

$\mathrm{S}-$ Saturados

$\mathrm{S}-$ Standard

SHRP - Strategic Highway Research Program

Superpave - Superior Performing Asphalt Pavements

TUC - temperatura de usinagem e compactação

$\mathrm{V}$ - Very heavy

VECD - Viscoelastic Continuum Damage

WRI - Instituto de Pesquisa de Western

$\gamma$ max - deformação máxima

$\delta$ - angulo de fase 



\section{CAPÍTULO 1. INTRODUÇÃO}

\subsection{DEFINIÇÃO E RELEVÂNCIA DO TEMA}

De acordo com a pesquisa da Confederação Nacional do Transporte (CNT) de Rodovias 2012, que se propõe a avaliar a situação das rodovias brasileiras a partir da perspectiva dos seus usuários, 9,9\% das rodovias avaliadas são consideradas como ótimas, $27,4 \%$ como boas, $33,4 \%$ são regulares, $20,3 \%$ estão ruins e $9 \%$ estão consideradas como péssimas. A pesquisa avaliou $95.707 \mathrm{~km}$ em todo o território brasileiro. Se comparados com os dados da pesquisa de 2011, houve uma piora na qualidade das estradas nacionais. No ano passado, 57,4\% foram classificadas como regulares, ruins ou péssimas, contra $62,7 \%$ este ano. $\mathrm{O}$ alto custo de manutenção das estradas e o crescente aumento da frota de bitrens em circulação no país tornou grande parte das rodovias precárias, causando insegurança e grandes prejuízos econômicos. Para suportar este desgaste sofrido pelo aumento do volume de tráfego, revestimentos asfálticos mais resistentes são necessários.

A construção de estradas mais resistentes requer conhecimentos de vários campos da engenharia, e de áreas básicas como a química, envolvendo técnicas de execução e o estudo de cada material envolvido como solos, agregados e materiais asfálticos. Entre esses materiais de pavimentação está o ligante asfáltico, oriundo do refinamento do petróleo.

A utilização do ligante asfáltico em pavimentação se justifica por diversas razões, dentre elas: (i) forte coesão dos agregados, permitindo uma flexibilidade controlável; (ii) durabilidade; (iii) resistência; (iv) baixa reatividade; (v) impermeabilidade; (vi) além de poder ser utilizado aquecido ou emulsionado, com ou sem a presença de aditivos. Como o ligante é um material termoviscoelástico, suas características influenciam diretamente a resposta das misturas asfálticas aos pulsos de carga associados à passagem do tráfego nos pavimentos.

A ciência dos ligantes asfálticos para pavimentação tem se desenvolvido, desde o início do século 20, com base na utilização de ligantes asfálticos puros e, mais tarde, na incorporação de diferentes modificadores com o objetivo de gerar um produto mais versátil e mais durável para resistir aos efeitos ambientais e das cargas excessivas do tráfego. O ligante asfáltico apresenta um comportamento de fluido viscoso em altas 
temperaturas e/ou durante carregamento lento e torna-se semi-sólido e quebradiço em baixas temperaturas e/ou durante carregamento rápido, podendo causar deformação permanente, trinca por fadiga e trinca por origem térmica no pavimento, limitando assim a sua aplicação. A complexa composição química do ligante asfáltico tem influência no desempenho físico e mecânico das misturas asfálticas, que consistem da junção do ligante com agregados graúdos e miúdos (por exemplo, pedra, areia, pó-depedra, cal).

Com o aumento no volume de tráfego e na frequência de carga, tem sido cada vez mais necessário o uso de modificadores das propriedades do ligante asfáltico, a fim de gerar um revestimento asfáltico mais resistente. Ligantes asfálticos modificados são obtidos a partir de uma mistura entre o ligante e o aditivo. Suas características finais dependem do ligante asfáltico utilizado, do teor e do tipo de aditivo. Os aditivos mais comuns são polímeros, fíleres minerais, asfaltos naturais, óleos aromáticos, ácidos e materiais reciclados como a borracha de pneus inservíveis e outros produtos à base de polímeros.

O ácido polifosfórico tem sido empregado nos Estados Unidos desde a década de 1970 e se supõe que atue como defloculante da fração de asfaltenos, retardando ou evitando a associação deles. O que se sabe é que o mecanismo de modificação do ligante asfáltico com ácido polifosfórico depende das características químicas do ligante asfáltico (BAUMGARDNER et al., 2005; MARTIN e BAUMGARDNER, 2006), porém não se sabe exatamente como este fenômeno se dá. Baumgardner et al. (2005) propuseram alguns possíveis mecanismos de enrijecimento do ligante asfáltico mediante a adição de ácido polifosfórico.

O ácido polifosfórico tem sido defendido pela indústria como um redutor da proporção de polímero, aparentemente com motivações econômicas, já que o custo do ácido é menor que o do polímero. O ácido polifosfórico parece preservar algumas características esperadas de um ligante asfáltico modificado com uma determinada proporção de polímero mesmo quando esta proporção é reduzida. Estudos têm mostrado o impacto da combinação do ácido polifosfórico com polímeros sintéticos: ele permite reduzir a proporção de polímero adicionada ao ligante asfáltico, o que provoca redução da viscosidade, mas proporcionando propriedades reológicas tão adequadas quanto às do ligante asfáltico modificado apenas com o polímero (MARTIN e BAUMGARDNER, 2006), além de melhorar a trabalhabilidade da mistura asfáltica e a 
estocagem do ligante asfáltico. A patente US 2006/0250886 indica que a combinação do asfalto-borracha com ácido polifosfórico permite melhorar tanto as propriedades reológicas do ligante asfáltico quanto das misturas asfálticas. Há informações muito limitadas sobre como a modificação do ácido afeta o desempenho da mistura asfáltica. O desafio dos pesquisadores e construtores é saber se a adição do ácido prejudicará ou não o desempenho da mistura asfáltica a longo prazo.

\subsection{OBJETIVOS}

A proposta deste trabalho é avaliar o efeito do teor de ácido polifosfórico (0,0, $0,5,1,0,1,5$ e 2,0\%) em ligantes asfálticos de composição química diferentes (LUBNOR e REDUC), classificados como penetração 50/70 e grau de desempenho diferentes. São consideradas a resistência à deformação permanente, avaliada por meio do ensaio de fluência e recuperação (MSCR), e a resistência à fadiga, avaliada por meio do ensaio acelerado de fadiga de ligantes asfálticos (LAS). São utilizados materiais em suas condições virgens e envelhecida a curto prazo na estufa de filme rotativo e a longo prazo no vaso de pressão. A caracterização dos ligantes asfálticos foi complementada por meio da construção de curvas-mestre e do ensaio de viscosidade rotacional.

\subsection{PROGRAMA LABORATORIAL}

Desenvolveu-se um programa experimental que englobou o ensaio de 10 amostras de ligantes asfálticos: duas amostras de ligantes puros (LUBNOR e REDUC), 4 amostras de ligante asfáltico proveniente da refinaria LUBNOR modificados com ácido polifosfórico e 4 amostras de ligante asfáltico proveniente da refinaria REDUC modificados com o mesmo ácido polifosfórico, nas condições virgens e envelhecidas a curto e a longo prazo. As amostras virgens foram submetidas à caracterização química por meio da cromatografia de camada fina, utilizando o equipamento IATROSCAN MK-6As, com intuito de determinar as frações de saturados, aromáticos, resinas e asfaltenos (SARA). A viscosidade rotacional dos ligantes asfálticos virgens foi determinada por meio do viscosímetro Brookfield, nas temperaturas de 135, 143, 150, 163 e $177^{\circ} \mathrm{C}$. A temperatura alta do grau de desempenho dos ligantes asfálticos foi determinada com base nos valores do parâmetro $\mathrm{G} / \operatorname{sen} \delta$ das amostras virgens, de acordo com o novo critério da especificação Superpave. As propriedades reológicas 
(rigidez e elasticidade) dos ligantes asfálticos foram determinadas por meio do ensaio de varredura de frequência (entre 0,1 e $100 \mathrm{rad} / \mathrm{s}$ ), nas temperaturas de 4, 16, 28, 40, 52, $64,76,88^{\circ} \mathrm{C}$. A determinação da rigidez e de elasticidade foi realizada para os ligantes asfálticos puros e modificados, nas três condições de envelhecimento (virgem, envelhecido a curto prazo e envelhecido a longo prazo). $\mathrm{O}$ desempenho dos ligantes asfálticos em relação à resistência à deformação permanente foi determinado por meio do ensaio de fluência e recuperação sob tensões múltiplas (MSCR). O ensaio de MSCR foi conduzido nas amostras puras e modificadas envelhecidas a curto prazo, na temperatura alta do grau de desempenho de cada ligante asfáltico. O desempenho dos ligantes asfálticos quanto à resistência à fadiga foi determinado por meio do ensaio acelerado de fadiga de ligantes asfálticos (LAS) nas temperaturas de 25 e $35^{\circ} \mathrm{C}$. O ensaio LAS foi conduzido nas amostras puras e modificadas envelhecidas a curto e a longo prazos.

\subsection{ESTRUTURA DA DISSERTAÇÃO}

No Capítulo 1 é discutido o problema e a relevância do tema de pesquisa, os objetivos, o programa laboratorial e ainda a estrutura do presente trabalho. O Capítulo 2 traz uma revisão bibliográfica sobre a composição química dos ligantes asfálticos, teorias sobre o mecanismo de ação do PPA em ligantes asfálticos, o uso de PPA em ligantes asfálticos e misturas asfálticas e a influência da composição química dos ligantes asfálticos no desempenho dos ligantes asfálticos modificados. O Capítulo 3 apresenta os materiais utilizados neste trabalho, bem como uma breve explicação dos experimentos realizados para testar tais materiais. O Capítulo 4 apresenta os resultados da adição de PPA na rigidez, na elasticidade e na viscosidade. O Capítulo 5 traz uma revisão bibliográfica sobre o ensaio de fluência e recuperação (MSCR), bem como os resultados do efeito do PPA na compliância não-recuperável e no percentual de recuperação dos ligantes asfálticos, a fim de avaliar o efeito do PPA na resistência à deformação permanente. No Capítulo 6 são discutidos os ensaios de caracterização do comportamento à fadiga dos ligantes asfálticos, além dos resultados de tolerância à fadiga das amostras puras e modificadas com PPA, obtidos por meio do ensaio acelerado de fadiga (LAS). Finalmente, o Capítulo 7 contém as conclusões resultantes desta realização da investigação e sugestões para estudos futuros nesta mesma linha de pesquisa. 


\section{CAPÍTULO 2. REVISÃO BIBLIOGRÁFICA}

Neste capítulo é feita uma revisão bibliográfica sobre a composição química dos ligantes asfálticos e são apresentadas as teorias propostas por pesquisadores sobre o mecanismo de ação de PPA em ligantes asfálticos. Também é feita uma revisão bibliografia dos efeitos da adição de PPA em ligantes asfálticos, da importância da composição química dos ligantes asfálticos nestes efeitos e da influência do PPA no desempenho das misturas asfálticas.

\subsection{LIGANTE ASFÁLTICO E SUA COMPOSIÇÃO QUÍMICA}

O ligante asfáltico é definido como um material praticamente não volátil, impermeável e livre de água, derivado do petróleo bruto. É completamente ou quase completamente solúvel em tolueno, e muito viscoso, ou próximo ao comportamento sólido, em temperaturas ambientes. O ligante asfáltico é constituído de hidrocarbonetos de massa molar e estrutura química diferentes. Em sua composição estão presentes principalmente heteroátomos como enxofre ( 0 a $9 \%)$, nitrogênio $(0$ a $2 \%)$ e oxigênio $(0$ a $2 \%$ ). Traços de metais também são encontrados. Em maior número estão o vanádio (mais que 2000 partes por milhão) e o níquel (mais de 200 partes por milhão) (LESUEUR, 2009). A natureza química do ligante asfáltico é geralmente descrita como parafínico, naftênico ou aromático, se a maior fração for de compostos saturados, cíclicos ou aromáticos, respectivamente (LESUEUR, 2009).

Devido à complexidade de sua composição química, alguns métodos de separação das frações dos ligantes asfálticos foram elaborados. O método mais utilizado é o do químico Corbett (1969), o qual assume que o ligante asfáltico é um material formado basicamente por quatro frações: saturados, aromáticos, resinas e asfaltenos, conhecidos como as frações SARA. Saturados, aromáticos e resinas constituem a fração maltênica, que possui baixa massa molar e polaridade e é solúvel em n-heptano. Os asfaltenos constituem a fração asfaltênica, que é a fração mais pesada e polar e insolúvel em n-heptano. A Figura 2.1 apresenta o esquema de separação química das frações do ligante asfáltico idealizada por Cobertt (1969). No entanto, a composição química dos asfaltos não pode ser definida com exatidão, por ser extremamente complexa e variável, dependendo do tipo do petróleo do qual se extrai o asfalto e de modificações decorrentes de tratamentos durante o refino ou durante sua vida de serviço. 


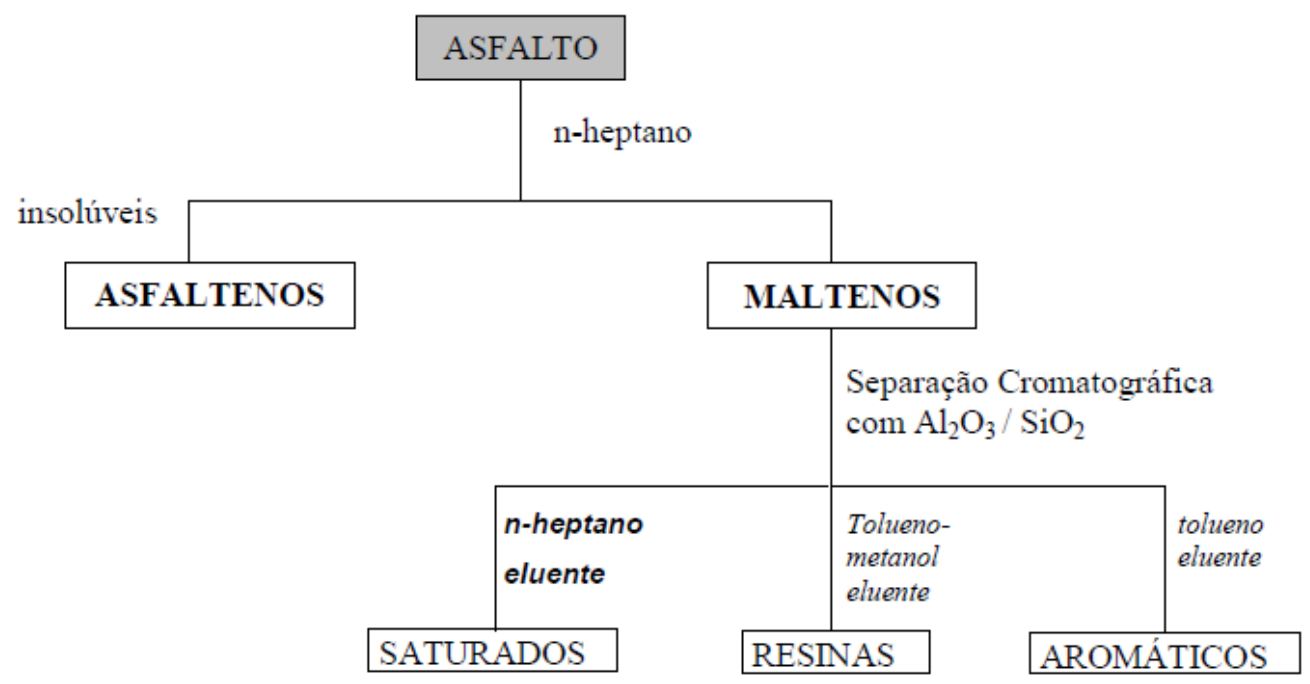

Figura 2.1- Esquema da separação química do ligante asfáltico (CORBETT, 1969)

Os saturados constituem certa de 5 a $15 \%$ do ligante asfáltico. Eles formam um liquido incolor ou de pouca coloração em temperatura ambiente, em função da temperatura de transição vítrea muito baixa $\left(-70^{\circ} \mathrm{C}\right)$ (LESUEUR, 2009). Os saturados são cadeias retas e ramificadas de hidrocarbonetos. Os componentes aromáticos são de baixa massa molar (600 g/mol) e em maior proporção no asfalto. Os aromáticos são os constituintes do ligante asfáltico, juntamente com as resinas, mais abundantes no ligante asfáltico, uma vez que a sua quantidade varia de 30 a 45\%. Essa fração forma um liquido de cor amarelada a avermelhada na temperatura ambiente. Os aromáticos são mais viscosos que os saturados, na temperatura ambiente, devido a alta temperatura de transição vítrea (aproximadamente $-20^{\circ}$ ).

As resinas, também conhecidas por aromáticos polares, também constituem a fração mais numerosa do ligante asfáltico (30 a 45\%). Se a frações de saturados e aromáticos têm a aparência de um óleo na temperatura ambiente, as resinas se comportam como um sólido preto em temperatura ambiente e não é claro se esta fração exibe uma temperatura de transição vítrea. As resinas são compostas de hidrogênio e carbono, com pequena proporção de oxigênio, enxofre e nitrogênio. São de natureza polar e fortemente adesiva. Koots e Speight $^{1}$ (1975) apud Lesueur (2009) mostraram que a composição das resinas é próxima à composição dos asfaltenos, exceto pela baixa massa molar e uma relação hidrogênio/carbono maior.

\footnotetext{
${ }^{1}$ Koots, J. A. e Speight, J. G. (1975). Relation of Petroleum Resins to Asphaltenes. Fuel, v.54, p.179-84.
} 
Os asfaltenos constituem de 5 a $20 \%$ do ligante asfáltico e é a fração mais estudada devido ao seu papel no comportamento da viscosidade (BRANTHAVER et al., 1994). Eles também são de grande interesse para os químicos de petróleo devido à sua importância no processamento do petróleo bruto. Os asfaltenos representam a classe de moléculas de baixa solubilidade do ligante asfáltico. São definidos como a parte insolúvel em n-heptano do ligante asfáltico, mas solúvel em tolueno. Os asfaltenos comportam-se como um pó preto em temperatura ambiente e são os principais responsáveis pela coloração preta do ligante asfáltico (LESUEUR, 2009).

A quantidade das frações dos ligantes asfálticos varia de acordo com a fonte do petróleo de base e com o processamento do ligante asfáltico. Shulga et al. (2012) avaliaram a composição química dos ligantes asfálticos de diferentes fontes do mundo (China, Venezuela, Canadá e Rússia) por meio do método SARA e observaram que as frações de saturados, aromáticos, resinas e asfaltenos varia significantemente para cada ligante asfáltico (Figura 2.2). Observa-se também que há uma variação na composição química do ligante asfáltico provocada pelo envelhecimento (Figura 2.3).

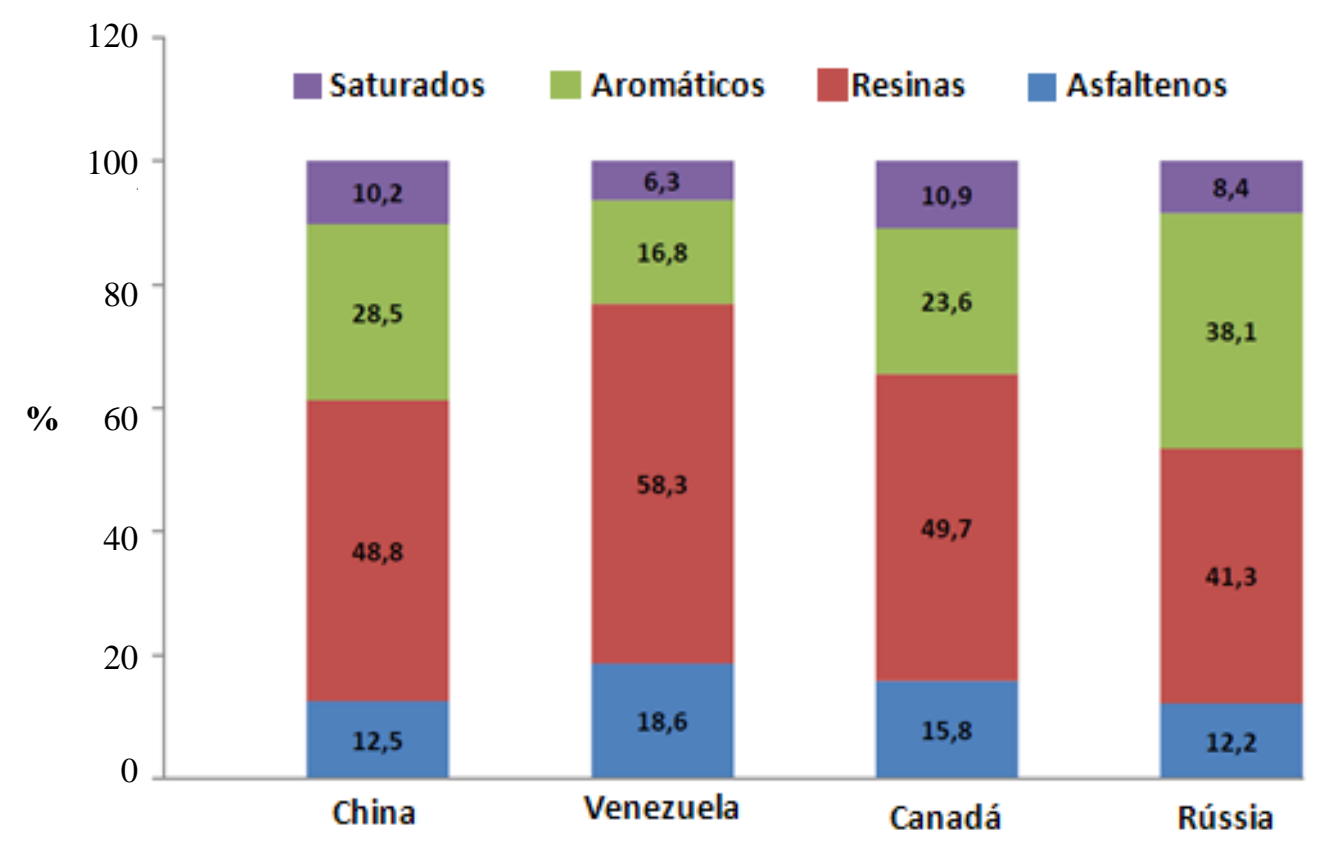

Figura 2.2 - Influência da origem na composição química SHULGA et al., (2012) 

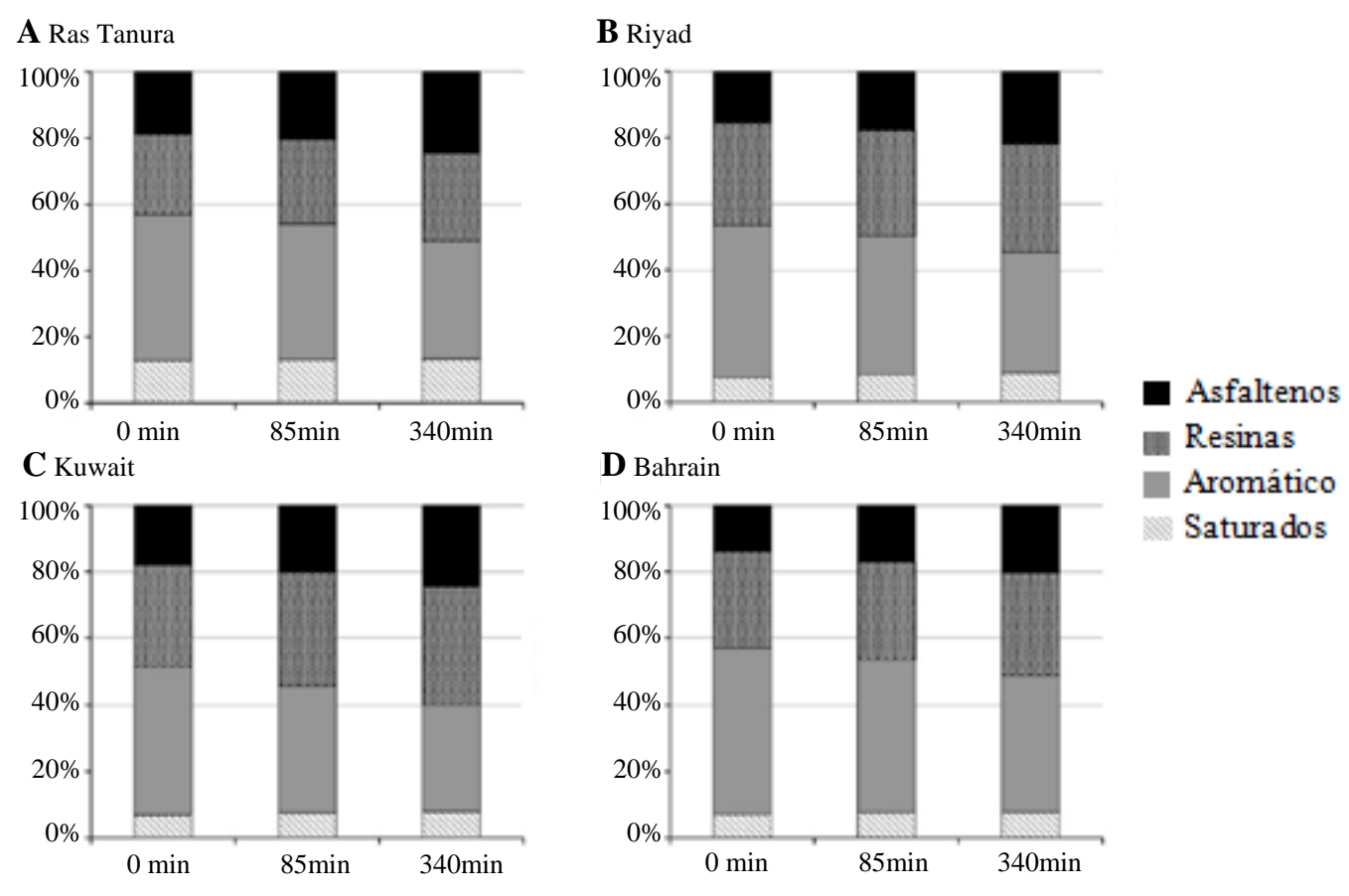

Figura 2.3 - Fração SARA para vários ligantes asfálticos antes e após 85 min e 340 min no envelhecimento no RTFOT (LESUEUR, 2009)

Rosinger (1914) $)^{2}$ apud Lesueur (2009) sugeriu uma estrutura coloidal para o ligante asfáltico. Os autores concluíram que os asfaltenos e o carbono livre apresentavam estruturas químicas muito parecidas e que os asfaltenos formavam uma suspensão coloidal na fase maltênica. As propriedades químicas, físicas e reológicas do ligante asfáltico dependem basicamente da sua estrutura coloidal e ligações entre os componentes. Cada um dos compostos presentes no ligante asfáltico exerce uma influência no comportamento do ligante asfáltico: (i) os saturados agem influenciando negativamente a suscetibilidade térmica, (ii) os aromáticos atuam no ligante provendo uma melhoria nas propriedades físicas, (iii) as resinas melhoram a ductibilidade do ligante e (iv) os asfaltenos contribuem aumentando a viscosidade e tornando os ligantes asfálticos menos susceptíveis a variações de temperatura (MORALES et al., 2004). Quanto maior o percentual de asfaltenos, mais duro e mais viscoso será o ligante asfáltico.

Os ligantes asfálticos podem ser classificados de três maneiras: tipo SOL, tipo GEL ou tipo SOL-GEL. As proporções de resinas e asfaltenos governam o comportamento como solução (SOL) ou como um gel (GEL) do CAP (Figura 2.4). Os ligantes asfálticos do tipo sol apresentam um comportamento newtoniano, enquanto os ligantes asfálticos do tipo gel

\footnotetext{
${ }^{2}$ Rosinger A. Beiträge zur Kolloidchemie des Asphalts. Kolloid-Z 1914;15:177-9.
} 
apresentam um comportamento não-newtoniano (GIAVARINI et al., 2000; POLACCO et al., 2006; LESUEUR, 2009 e HUANG, 2011).

Em termos de estrutura, o comportamento tipo SOL ocorre quando as micelas de asfaltenos estão completamente dispersas e não interagem com os demais componentes. A estrutura do tipo GEL resultaria em um patamar do módulo em função da temperatura e frequência, o que nunca foi observado em ligantes asfálticos. Grande parte dos ligantes asfálticos apresenta comportamento intermediário, uma vez que sua estrutura é uma mistura das micelas existentes no ligante asfáltico do tipo SOL e a estrutura do ligante asfáltico tipo GEL. Eles ligantes asfálticos são classificados como ligantes GEL-SOL ou soluções coloidais elásticas. (LESUEUR, 2009). A maioria dos resíduos de vácuo e os asfaltos para pavimentação são do tipo "SOL-GEL", ao passo que os asfaltos oxidados ou soprados são do tipo "GEL".

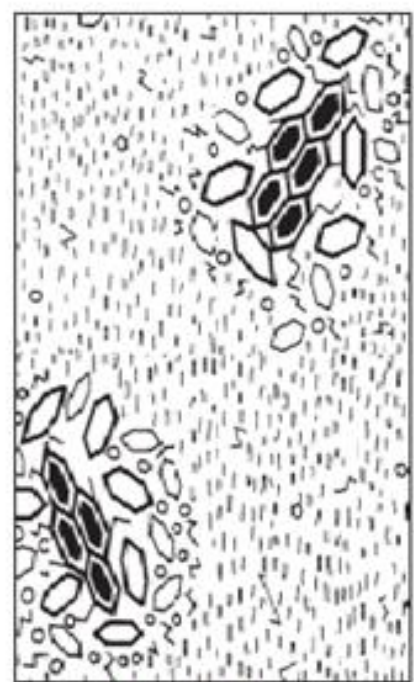

Ligante SOL

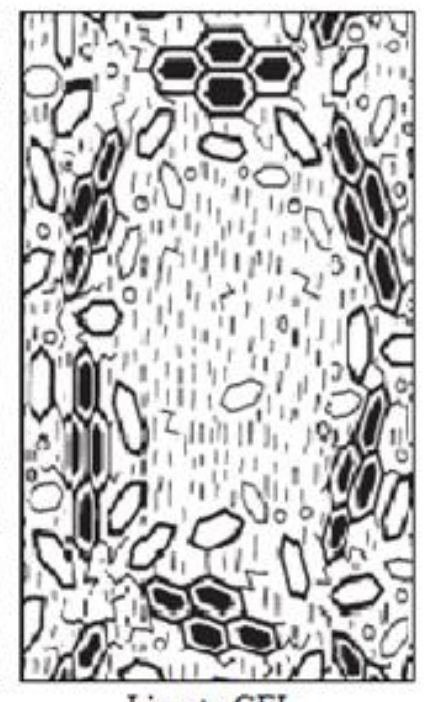

Ligante GEL

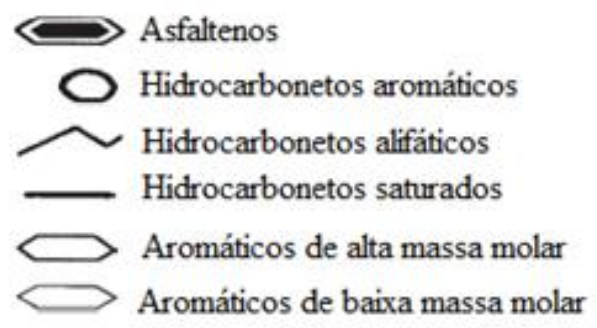

Figura 2.4 - Representação esquemática de ligantes do tipo SOL e GEL (adaptado de SHELL, 2003).

Em 2005, o Instituto de Pesquisa de Western (WRI) avaliou a relação entre a estrutura coloidal do ligante asfáltico e o mecanismo de ação do PPA em ligantes asfálticos. Os autores observaram que a adição de PPA aumenta a característica GEL do ligante asfáltico e que o impacto da adição de PPA nas propriedades reológicas dos ligantes asfálticos está diretamente relacionado com a característica SOL-GEL do ligante asfáltico de base (ROBERTSON et al., 2005). Bonemazzi e Giavarini (1999) também avaliaram que a adição de PPA modifica a estrutura do ligante asfáltico, do tipo SOL para o tipo GEL. Geralmente, a diferença entre os 
ligantes asfálticos do tipo SOL e os ligantes asfálticos do tipo GEL é que o ligante asfáltico do tipo GEL apresenta uma maior fração de asfaltenos. Ligantes asfálticos do tipo GEL são mais susceptíveis ao envelhecimento termo-oxidativo, enquanto os ligantes asfálticos tipo SOL não possuem uma grande fração de asfaltenos e são menos susceptíveis ao envelhecimento (HUANG, 2011).

Apesar dos problemas relativos à determinação da estrutura química do asfalto e das controvérsias vigentes, um aspecto positivo merece menção. O comportamento dos asfaltos modificados por polímeros, embora morfologicamente mais complexo que o de um asfalto convencional, é paradoxalmente mais simples de ser interpretado, uma vez que é bastante influenciado pelas características do polímero, que são sempre mais bem conhecidas que as dos asfaltos (POLACCO et al., 2006).

O ligante asfáltico é afetado por diversos fatores, entre eles, a presença de oxigênio e a variação de temperatura. A reatividade do ligante asfáltico com o oxigênio é fortemente influenciada pela temperatura, onde os asfaltenos apresentam maior reatividade, seguidos das resinas, aromáticos e saturados. O efeito da oxidação é o aumento na consistência do ligante, o que pode diminuir a vida útil do pavimento. O ligante asfáltico usado em misturas asfálticas à quente sofre envelhecimento em três etapas: (i) usinagem da mistura asfáltica, que é a etapa de maior impacto no envelhecimento devido às elevadas temperaturas de usinagem, (ii) estocagem, transporte, espalhamento e compactação, ainda associada a temperaturas elevadas, e (iii) vida útil do pavimento, que representa o pavimento em serviço, sendo o envelhecimento causado pela ação do meio ambiente. O envelhecimento do ligante afeta diretamente as suas propriedades químicas e reológicas. Para eliminar os riscos de envelhecimento precoce, o ligante deve ser manuseado e estocado à temperatura mais baixa possível, mantendo fluidez suficiente, e deve-se evitar o alto teor de vazios na estrutura da mistura asfáltica, de modo a minimizar a oxidação.

\subsection{ADIÇÃo DE ÁCIDO POLIFOSFÓRICO AO LIGANTE ASFÁLTICO}

O ácido polifosfórico (PPA) é um oligômero (conjunto de cadeias) do ácido fosfórico, sendo que a produção de PPA com alto grau de pureza pode ser feita tanta pela desidratação do ácido fosfórico ou pelo aquecimento de pentóxido de fósforo disperso em ácido fosfórico. A modificação de ligantes asfálticos por ácido polifosfórico não é uma prática recente (BAUMGARDNER et al., 2005). Desde a década de 1970, ligantes asfálticos têm sido 
modificados com ácido polifosfórico, na tentativa de aumentar a viscosidade sem reduzir substancialmente a penetração, com o objetivo de obter ligantes asfálticos com maior resistência à deformação permanente, sem prejudicar a resistência à formação de trincas de origem térmica, além de produzir um ligante asfáltico de menor suscetibilidade térmica (BAUMGARDNER, 2012).

Mais recentemente, o ácido polifosfórico tem sido empregado para ampliar a faixa de temperatura de trabalho dos ligantes asfálticos, isto é, o grau de desempenho segundo a especificação SUPERPAVE (Superior Performing Asphalt Pavements). A adição de ácido polifosfórico pode proporcionar melhoria das propriedades reológicas do ligante asfáltico nas temperaturas altas, sem afetar o PG do material nas temperaturas baixas (BAUMGARDNER et al., 2005; KODRAT et al., 2007). No entanto, sabe-se que o mecanismo de modificação com o ácido polifosfórico depende das características químicas do ligante asfáltico (BAUMGARDNER et al., 2005; BAUMGARDNER, 2012), logo os benefícios obtidos pela adição do ácido não são os mesmos para todos os tipos de ligante asfáltico.

Sabe-se é que o mecanismo de modificação do ligante asfáltico com ácido polifosfórico depende das características químicas do ligante asfáltico (BAUMGARDNER et al., 2005; MARTIN e BAUMGARDNER, 2006), porém não se sabe exatamente como este fenômeno se dá. Orange et al. (2004) avaliaram dois ligantes asfálticos distintos: um parafínico (70/100) e outro naftênico (50/70), ambos com PG 64-77. Os resultados indicaram que ocorre uma reação química entre o PPA e o ligante asfáltico e que os produtos da reação são compostos insolúveis em meio polar, explicando assim o alto teor de asfaltenos após à adição do PPA. Os autores indicam que a adição de ácido polifosfórico tem impacto significativamente maior sobre as propriedades reológicas de ligantes asfálticos de natureza predominantemente aromáticos-naftênicos (ORANGE et al., 2004), uma vez que estes ligantes asfálticos apresentam um maior teor de asfaltenos (LEITE et al., 2004).

Orange et al. (2004) supõem que o PPA atue como defloculante da fração asfaltenos, levando ao aumento da concentração e da superfície de interação dos asfaltenos com a fase maltênica do ligante asfáltico (Figura 2.5), formando um complexo (asfalteno-PPA-resina). A dispersão da fração de asfaltenos faz com que a quantidade desta fração aumente, uma vez que há a conversão de resinas em asfaltenos e de aromáticos em resinas, havendo uma mudança na estrutura coloidal do ligante asfáltico (ORANGE et al., 2004 e LEITE et al., 2004). O aumento da proporção de asfaltenos não está relacionado ao típico processo de oxidação do ligante asfáltico, mas sim a um aumento de polaridade do complexo asfalteno- 
PPA-resina (HUANG et al., 2008). Baumgardner et al. (2005) também observaram um aumento da concentração de asfaltenos. Os autores analisaram os asfaltenos de dois ligantes asfálticos distintos (Arábico e Venezuelano) por meio da técnica de ressonância magnética nuclear. Nos ligantes puros, não foi observada a presença de compostos fosforados na fração de asfaltenos, enquanto nos ligantes modificados, a presença de compostos fosforados foi observada no precipitado, indicando que o PPA reage preferencialmente com a fração asfaltênica dos ligantes asfálticos

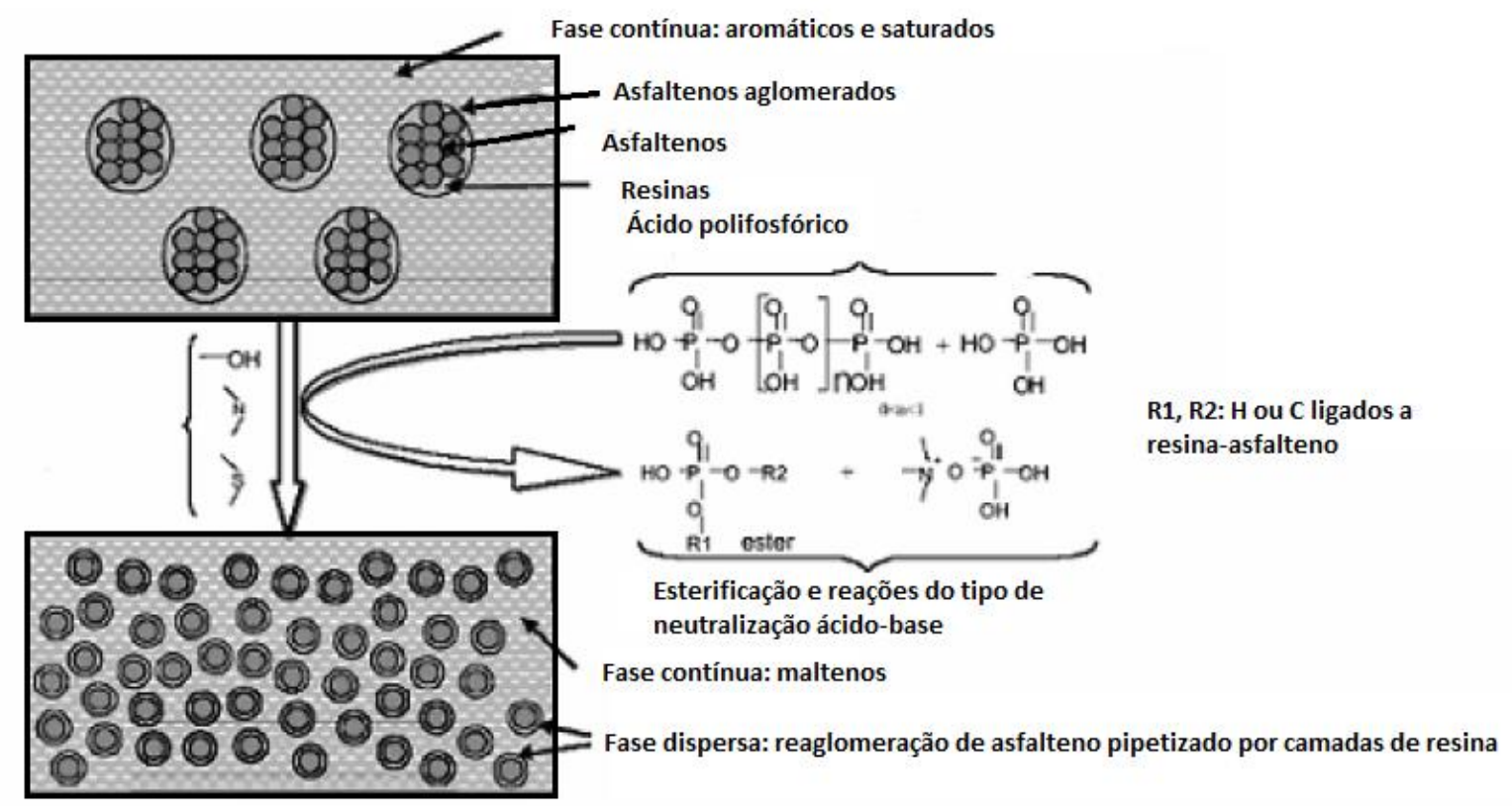

Figura 2.5 - Mecanismo hipotético de ação proposto para a reação entre o ácido polifosfórico e o ligante asfáltico (ORANGE et al., 2004)

Masson (2008) aponta que o ácido polifosfórico é um polímero de cadeia curta, cuja reação com o ligante asfáltico é pouco entendida. Como a composição química do ligante asfáltico apresenta compostos muito variados, as reações do mecanismo de ação do PPA em ligantes asfálticos são extremamente complexas (ORANGE et al., 2004, BAUMGARDNER et al., 2005). A fosforilação é a principal reação do mecanismo. Nesta reação, o PPA protona sítios básicos do ligante asfáltico, induzindo a uma perda da ligação de hidrogênio e uma desagregação das moléculas de asfaltenos. Dessa forma, há uma maior disperação de asfaltenos de domínios menores (Figura 2.6). 


\section{Fosforilação}

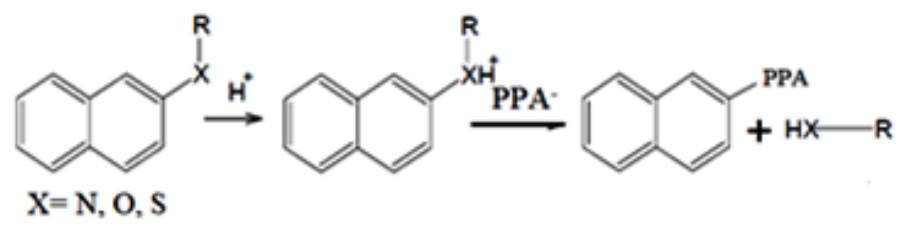

Figura 2.6 - Reação de fosforilação do PPA com ligante asfáltico (BAUMGARDNER et al., 2005)

No entanto, a reação de fosforilação não é a única reação que ocorre quando há adição de PPA ao ligante asfáltico. Deslocamento nucleofílico nos saturados, alquilação de aromáticos com sulfetos ou álcoois e alquilação de aromáticos com alcanos são alguns exemplos de reações secundárias (BAUMGARDNER et al., 2005) (Figura 2.7)

(a) Deslocamento nucleofilico nos saturados<smiles>[R]CS[R17]([R17])C[R]</smiles>

(b) Alquilação de aromáticos com sulfetos, álccois

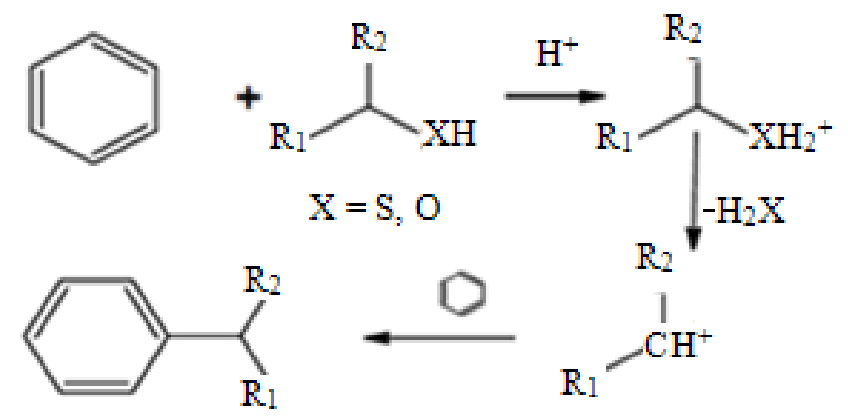

(c) Alquilação de aromáticos comalcanos

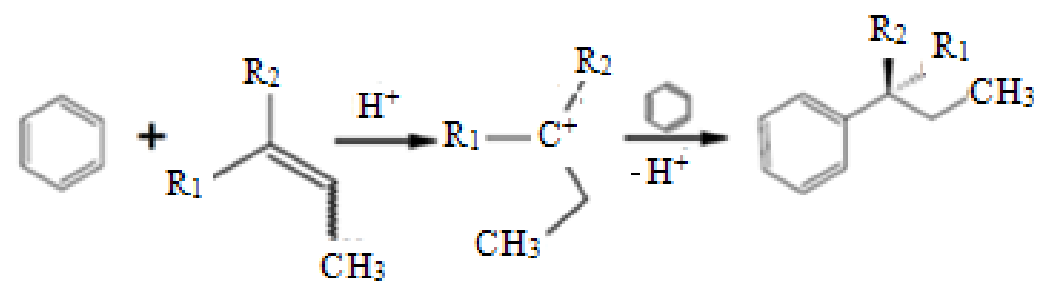

Figura 2.7 - Reações secundárias do PPA com o ligante asfáltico (Baumgardner et al., 2005) 
No que se refere à incorporação de PPA ao ligante asfáltico, Kodrat et al. (2007) apontam que a adição de PPA pode ser feita de três maneiras: (i) como catalizador na modificação dos ligantes asfálticos no processo de sopragem, processo no qual o ligante asfáltico é submetido a aquecimento e mistura na presença de um gás (ar, oxigênio ou oxigênio e um gás inerte); (ii) como um aditivo puro, sem a modificação do ligante asfáltico por sopragem; e (iii) como um acelerador da reação química entre terpolímero reativo (polímero formado por três monômeros diferentes, por exemplo, Evaloy) e o ligante asfáltico, acarretando a redução no teor de polímero. Pesquisas recentes (FAXINA e SUÁREZ, 2011; DOMINGOS, 2011; DOMINGOS e FAXINA, 2011a,b; FAXINA, 2011; FAXINA, 2010) têm avaliado o impacto da adição de PPA a ligantes asfálticos modificados por polímeros puros e por borracha de pneu descartados, com os objetivos de reduzir a proporção de polímeros ou borracha moída e melhorar a estabilidade à estocagem dos ligantes asfálticos modificados.

Fee et al. (2010) avaliaram que a adição de PPA no grau de desempenho dos ligantes asfálticos e observaram que a adição de PPA promove um aumento significativo na temperatura alta do PG e mantém praticamente inalterada a temperatura baixa do PG (Figura 2.8). D’Angelo (2012) avaliou o efeito de diferentes teores de ácido polifosfórico em ligantes asfálticos de diferentes fontes e observou que os ligantes asfálticos se comportam de maneira distinta à modificação pelo ácido. O autor adicionou 0,5\% de PPA $105 \%$ em dois ligantes asfálticos muito diferentes quimicamente: da Venezuela (PG 70-22) e da Arábia (PG64-22). O autor observou um aumento significativo na temperatura alta do grau de desempenho dos ligantes asfálticos, mas o ligante asfáltico da Venezuela apresentou maior sensibilidade à adição de PPA (Figura 2.9).

Testes feitos pela Administração Rodoviária Federal dos Estados Unidos (FHWA) também indicaram uma variação significativa no aumento de rigidez provocada pela adição de PPA de ligantes asfálticos de diferentes fontes (D’ANGELO, 2012). Os resultados dos testes estão mostrados na Figura 2.10. Os resultados mostram que a adição de PPA não é muito expressiva para o ligante asfáltico da Califórnia (ABM-1), mesmo para teores maiores que 3\%. Já o ligante asfáltico de Boston (AAK-1) apresenta um aumento de rigidez significativo com a adição de 3\% de PPA. Enquanto o ABM-1 aumenta 3 graus na temperatura alta do grau de desempenho do ligante asfáltico, o AAK-1 aumenta 47 graus. 


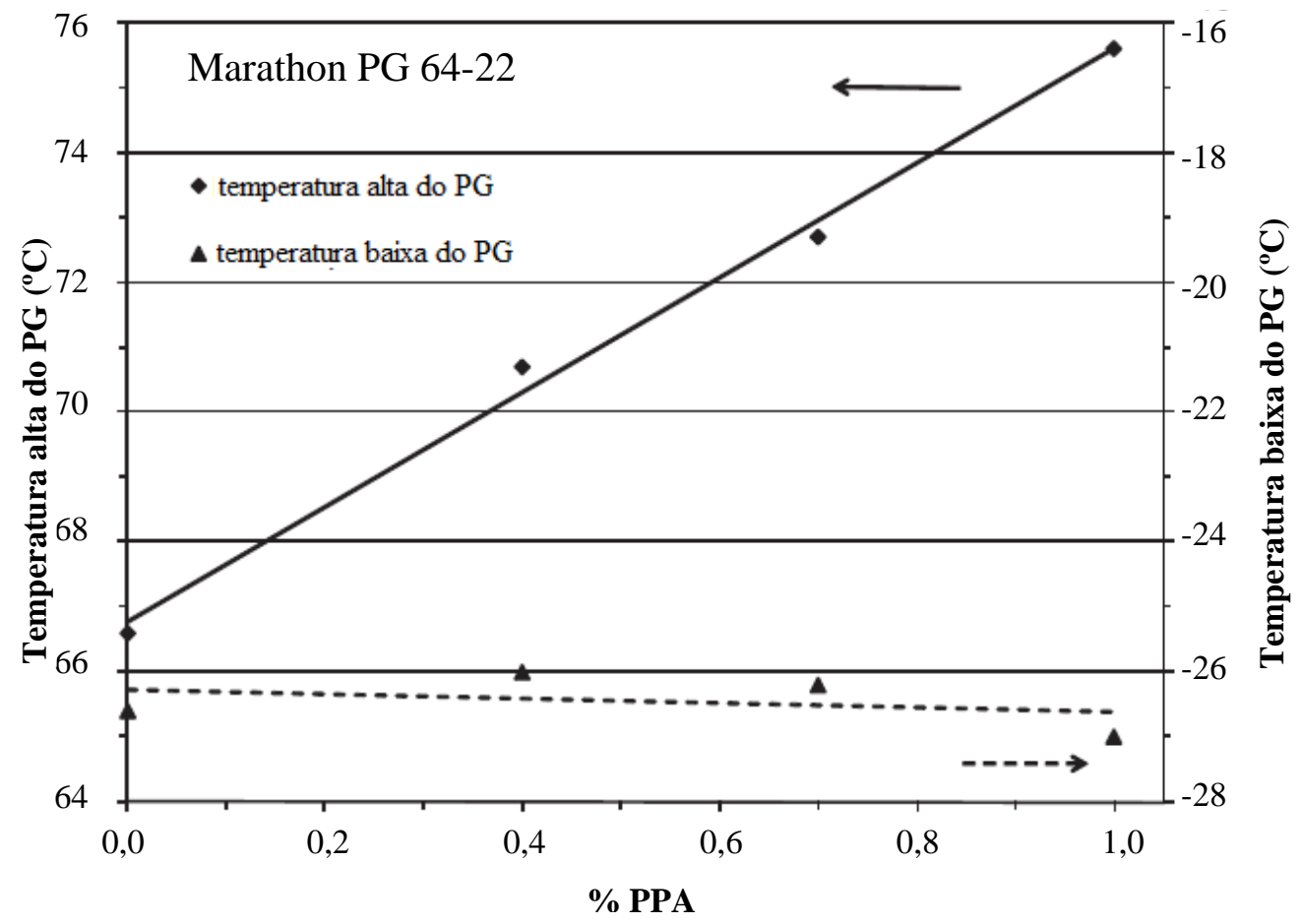

Figura 2.8 - Efeito do PPA no grau de desempenho (FEE et al., 2010)

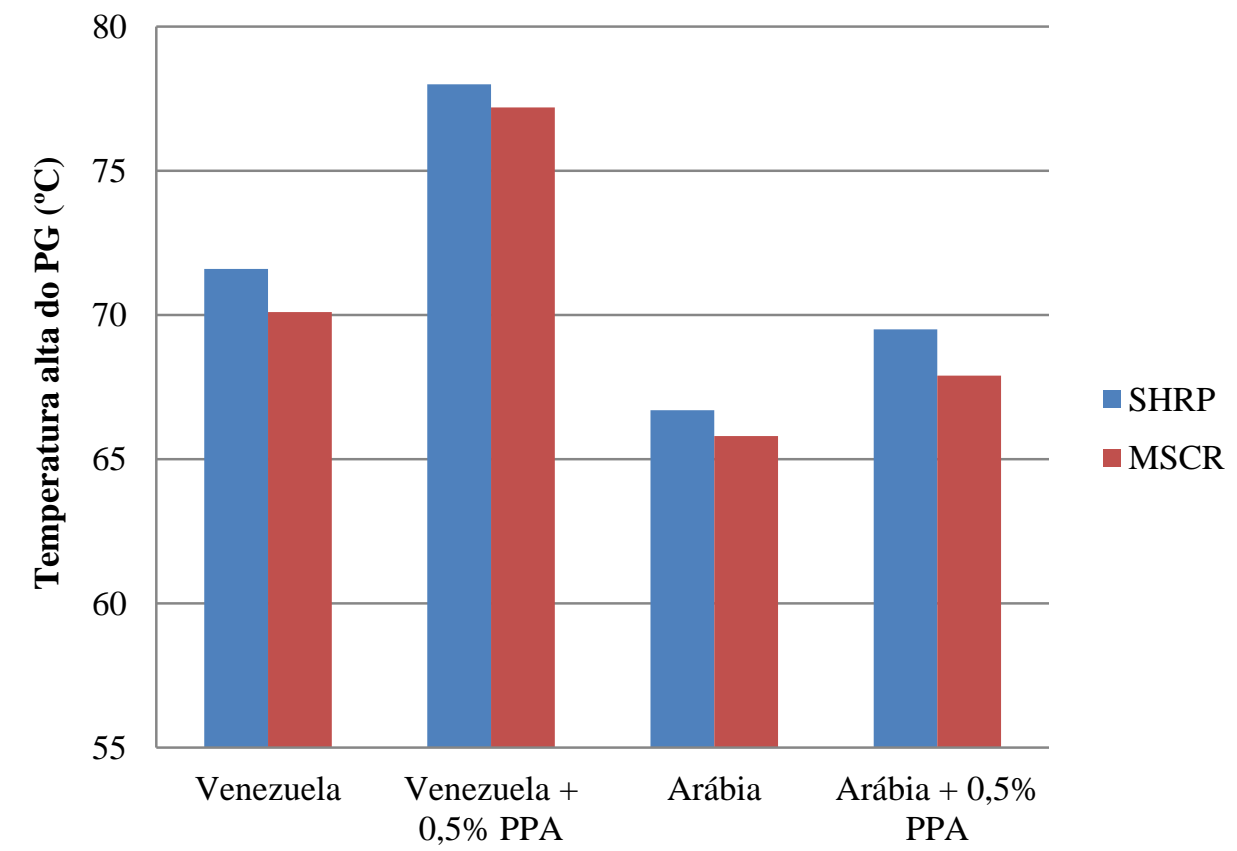

Figura 2.9 - Efeito da adição de PPA na temperatura alta do grau de desempenho de ligantes asfálticos de diferentes fontes (D'ANGELO, 2012) 


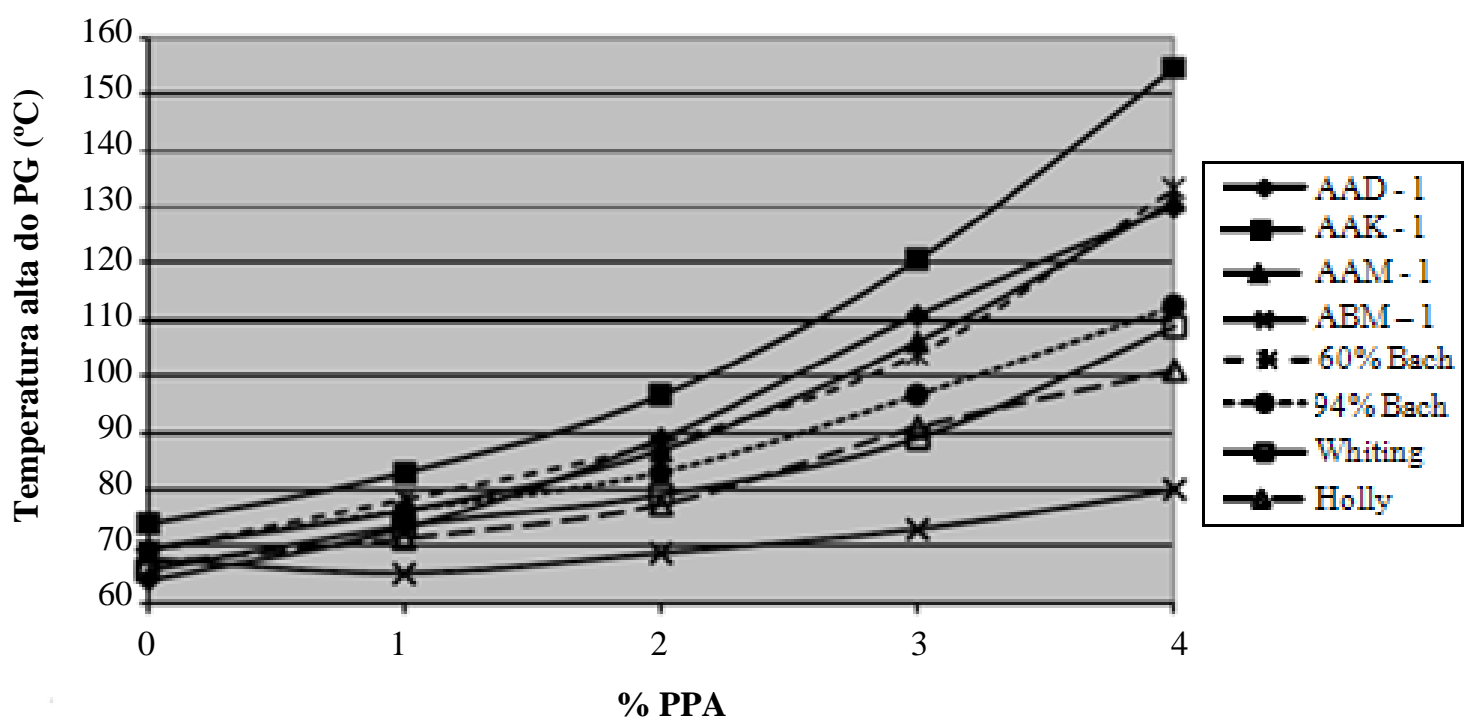

Figura 2.10 - Variações na temperatura alta do PG em função do teor de PPA para diferentes tipos de ligantes asfálticos (D’ANGELO, 2012)

Segundo Orange et al. (2004), o efeito da adição de PPA na modificação de ligantes asfálticos também promove um acréscimo no ponto de amolecimento, um aumento na temperatura alta do grau de desempenho, um decréscimo na penetração e uma melhoria na elasticidade e rigidez dos ligantes asfálticos. Shulga et al. (2012) avaliaram o efeito da adição de PPA em ligantes asfálticos de diferentes países (China, Venezuela, Canadá e Rússia) e observaram uma diminuição na penetração e um aumento na viscosidade, na rigidez e no ponto de amolecimento dos ligantes asfálticos. Apenas o ligante asfáltico proveniente do Canadá não apresentou modificações nos resultados de ponto de amolecimento após a adição de PPA. Shulga et al. (2012) também avaliaram a suscetibilidade ao envelhecimento de ligantes asfálticos de diferentes fontes modificados com PPA e observaram que a adição de PPA aumenta a penetração retida dos ligantes asfálticos, o que indica uma menor suscetibilidade ao envelhecimento. Os autores observam que a adição de PPA melhora as propriedades dos ligantes asfálticos tanto em temperaturas altas quanto em temperaturas baixas. De acordo com os autores, a adição de 0,5\% de PPA foi suficiente para aumentar a temperatura alta do grau de desempenho dos ligantes asfálticos provenientes da Venezuela e da Rússia. Mas, para os ligantes asfálticos da China e do Canadá, seria necessário um maior teor de PPA para aumentar o nível do PG (Figura 2.11). Os autores também concluíram que o teor de ácido polifosfórico deve ser escolhido individualmente para cada tipo de ligante asfáltico, levando em consideração sua composição química. 


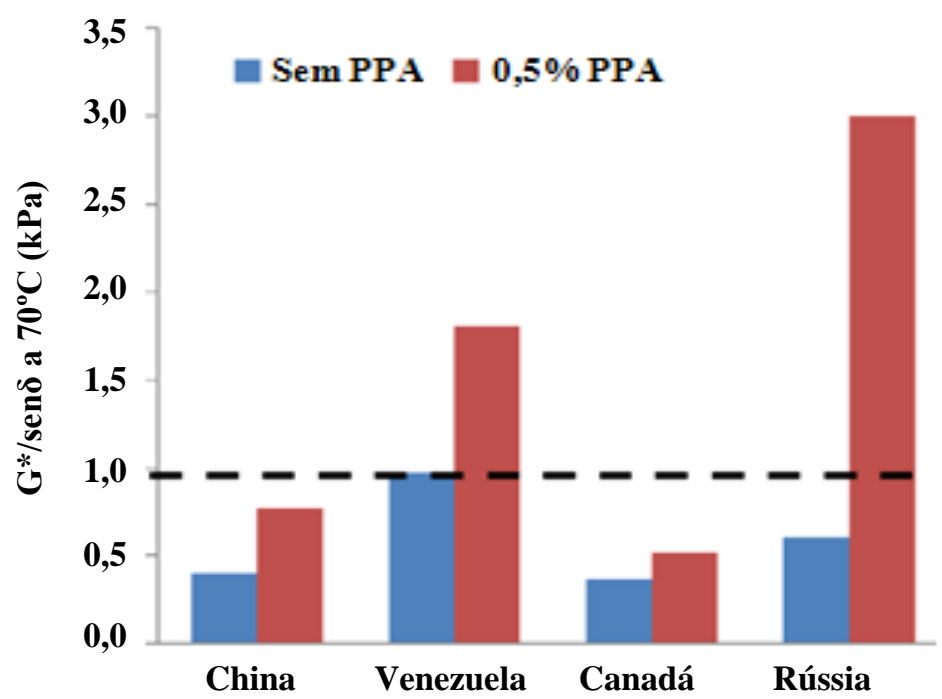

Figura 2.11 - Variação do parâmetro G*/sen $\delta$ em função da adição de PPA para ligantes asfálticos de diferentes fontes (SHULGA et al., 2012)

Tabela 2.1 - Propriedades dos ligantes asfálticos puros e modificados (FILIPPIS et al., 1995)

\begin{tabular}{|c|c|c|c|c|c|c|}
\hline \multirow{2}{*}{ ligante asfáltico } & \multirow{2}{*}{ aditivo } & \multirow{2}{*}{$\operatorname{PEN}^{*}$ (dmm) } & \multirow{2}{*}{$\mathbf{P A}^{* *} \circ \mathbf{C}$} & \multicolumn{2}{|c|}{ Viscosidade (Pa.s) } & \multirow{2}{*}{ Envelhecimento (\%) } \\
\hline & & & & Inicial & Após RTFOT & \\
\hline \multirow{5}{*}{ SR-5 } & & 147 & 44 & 24,5 & 118 & 382 \\
\hline & $\mathrm{H} 3 \mathrm{PO} 4$ & 70 & 52 & 62,5 & 118 & 89 \\
\hline & (HPO3)n & 62 & 58 & 107 & 235 & 119 \\
\hline & $\mathrm{P} 2 \mathrm{O} 5$ & 115 & 47 & 34,5 & 65 & 88 \\
\hline & $\mathrm{PCl} 3 \mathrm{O}$ & 50 & 54 & 105 & 108 & 3 \\
\hline \multirow{5}{*}{ SR-6 } & & 160 & 43 & 23 & 73 & 217 \\
\hline & H3PO4 & 93 & 50 & 45 & 128 & 184 \\
\hline & (HPO3)n & 82 & 53 & 66 & 149 & 126 \\
\hline & P2O5 & 173 & 44 & 28 & 45 & 60 \\
\hline & $\mathrm{PBr} 3$ & 54 & 56 & 86 & 153 & 78 \\
\hline \multirow{5}{*}{ SR-7 } & & 180 & 39 & 27 & 91 & 237 \\
\hline & H3PO4 & 116 & 47 & 50 & 140 & 180 \\
\hline & (HPO3)n & 68 & 58 & 104 & 242 & 132 \\
\hline & $\mathrm{P} 2 \mathrm{O} 5$ & 177 & 42 & 31,5 & 83 & 163 \\
\hline & $\mathrm{PCl} 5$ & 113 & 47 & 54,5 & 108 & 98 \\
\hline \multirow{3}{*}{ SR-8 } & & 133 & 44 & 60 & 153 & 155 \\
\hline & $\mathrm{H} 3 \mathrm{PO} 4$ & 71 & 53 & 140 & 150 & 7 \\
\hline & I2 & 108 & 49 & 200 & 420 & 110 \\
\hline
\end{tabular}

**PA $=$ Ponto de amolecimento 
Filippis et al. (1995) observaram que a adição de ácido polifosfórico a resíduos de vácuo é similar ao efeito induzido pelo processo de sopragem, mas mais econômico, uma vez que a modificação por ácido é um processo de menor custo quando comparado à sopragem. Os autores observaram um aumento no ponto de amolecimento, na viscosidade e na resistência ao envelhecimento e uma diminuição na penetração (Tabela 2.1). Leite et al. (2004) avaliaram o efeito da adição de três teores de PPA $(0,7,1$ e 1,2\%) no resíduo de vácuo e observaram um decréscimo na penetração com o acréscimo no teor de ácido. Os autores também observaram um aumento no ponto de amolecimento e na viscosidade e um aumento na temperatura alta do PG e na suscetibilidade térmica dos ligantes asfálticos (Tabela 2.2).

Tabela 2.2 - Comparação dos resultados de amostra de ligante asfáltico com e sem tratamento com ácido polifosfórico (LEITE et al., 2004)

\begin{tabular}{|c|c|c|c|c|c|}
\hline Ensaio & Resíduo de vácuo & & ostras m & ficadas & PA \\
\hline Teor de PPA $(\% \mathrm{~m} / \mathrm{m})$ & & 0,7 & 1 & 1 & 1,2 \\
\hline Compatibilidade $48 \mathrm{~h}(\Delta \circ \mathrm{C})$ & & 1,2 & 0,2 & 0 & \\
\hline Teor de asfalteno $(\% \mathrm{~m} / \mathrm{m})$ & 6,2 & & & & 11,2 \\
\hline Nitrogênio báscio total & 0,25 & & & & 0,26 \\
\hline Penetração a $25{ }^{\circ} \mathrm{C}(\mathrm{dmm})$ & 142 & 118 & 100 & 104 & 90 \\
\hline Viscosidade a $135^{\circ} \mathrm{C}(\mathrm{cP})$ & & & 303 & & \\
\hline IST & $-1,4$ & $-0,1$ & $-0,5$ & $-0,2$ & 0 \\
\hline Ponto de amolecimento $\left({ }^{\circ} \mathrm{C}\right)$ & 40 & 45,3 & 46 & 46,6 & 48,6 \\
\hline Viscosidade a $60^{\circ} \mathrm{C}, \mathrm{P}$ & 530 & 1101 & 1987 & 1482 & \\
\hline Cisalhamento $\mathrm{G}^{*} / \operatorname{sen} \delta,{ }^{\circ} \mathrm{C}$ & 46 & 58 & & 58 & 58 \\
\hline Perda de massa, \% & 0,02 & 0,08 & 0,09 & 0,08 & 0,069 \\
\hline Ductilidade a $25^{\circ} \mathrm{C}, \mathrm{cm}$ & $>100$ & 146,5 & 135 & 126 & \\
\hline Viscosidade a $60^{\circ} \mathrm{C}, \mathrm{P}$ & 760 & 2145 & 4575 & 3263 & \\
\hline Cisalhamento $\mathrm{G}^{*} / \mathrm{sen} \delta,{ }^{\circ} \mathrm{C}$ & & 58 & & 58 & 58 \\
\hline Cisalhamento $\mathrm{G}^{*} \cdot \operatorname{sen} \delta,{ }^{\circ} \mathrm{C}$ & & 10 & & 16 & 16 \\
\hline Fluência - BBR, ${ }^{\circ} \mathrm{C}$ & -18 & -18 & & -12 & -12 \\
\hline TIPO DE CAP - ANP & nenhum & CAP 7 & $85 / 100$ & CAP 7 & CAP 7 \\
\hline Grau de desempenho PG X-Y & $46-28$ & $58-28$ & & $58-22$ & $58-22$ \\
\hline $\begin{array}{l}\text { Faixa de plasticidade }(\mathrm{X}-\mathrm{Y}) \text {, } \\
{ }^{\circ} \mathrm{C}\end{array}$ & 74 & 86 & & 80 & 80 \\
\hline
\end{tabular}

Cao et al., (2011) modificaram o ligante asfáltico classificado como penetração 60/80 com quatro teores de ácido polifosfórico $(0,6,1,0,1,5$ e 2,0\%) e avaliaram o efeito da proporção de PPA por meio de análise de variância (Statistical Analysis of One-Way Variance - ANOVA). Os autores observaram um aumento no ponto de amolecimento, redução na penetração e aumento na viscosidade rotacional do ligante asfáltico, sendo que estes efeitos foram maiores para os teores mais elevados de modificador (Tabela 2.3). Os autores também observaram que as viscosidades a $135^{\circ} \mathrm{C}$ não superaram o limite estabelecido pela especificação Superpave (3,0 Pa.s), concluindo que a adição de PPA aumenta a 
viscosidade dos ligantes asfálticos, porém a sua trabalhabilidade não é comprometida. Os autores também observaram, por meio dos resultados obtidos no reômetro de flexão em viga (BBR), que a adição de PPA acarretou um pequeno aumento na rigidez dos ligantes asfálticos sob baixas temperaturas (Tabela 2.3).

Tabela 2.3 - Valores de ponto de amolecimento, penetração e viscosidade para os ligantes puro e modificados com PPA (CAO et al., 2011)

\begin{tabular}{|c|c|c|c|c|c|c|c|}
\hline \multirow{2}{*}{$\%$ PPA } & \multirow{2}{*}{$\begin{array}{l}\text { ponto de amolecimento } \\
\qquad\left({ }^{\circ} \mathrm{C}\right)\end{array}$} & \multicolumn{3}{|c|}{ penetração (dmm) } & \multicolumn{2}{|c|}{ viscosidade $(\mathbf{m P a} \cdot \mathbf{s})$} & \multirow{2}{*}{$\begin{array}{c}\text { Rigidez a baixa } \\
\text { temperatura } \\
\text { (MPa) }\end{array}$} \\
\hline & & $15^{\circ} \mathrm{C}$ & $25^{\circ} \mathrm{C}$ & $30^{\circ} \mathrm{C}$ & $60^{\circ} \mathrm{C}$ & $135^{\circ} \mathrm{C}$ & \\
\hline $\mathbf{0}$ & 51,8 & 21,2 & 71,4 & 156,3 & 310500 & 496 & 315,3 \\
\hline 0,6 & 53,1 & 19,7 & 59,8 & 118,6 & 420500 & 620 & 319,7 \\
\hline 1 & 54,8 & 18,9 & 56,7 & 112,4 & 473000 & 635 & 321,3 \\
\hline 1,5 & 58,2 & 18,1 & 51,2 & 95,9 & 720000 & 807 & 326,3 \\
\hline 2 & 62,8 & 17,3 & 49,2 & 90,3 & 1570000 & 1150 & 328,7 \\
\hline
\end{tabular}

Fernandes (2011) observou que o ligante + PPA apresentou melhor desempenho que o ligante puro evidenciado pelo aumento do módulo complexo (Figura 2.12) e pelo aumento da elasticidade, evidenciado pela redução da tanઈ (Figura 2.13), além do aumento no ponto de amolecimento e na redução da penetração (Figura 2.14). O autor também avaliou o efeito da adição do líquido da castanha do caju (LCC) nos ligantes asfálticos com e sem PPA. O autor observou aumento do módulo complexo (Figura 2.12) e pelo aumento da elasticidade (Figura 2.13), mas os efeitos do LCC foram menos pronunciados do que efeitos causados pelo PPA.

Fernandes (2011) observou que a adição de LCC ao ligante asfáltico + PPA promoveu uma redução na viscosidade do ligante asfáltico (Figura 2.15) e consequentemente na temperatura de usinagem e compactação, melhorando a trabalhabilidade do ligante asfáltico, além de promover uma redução nos custos de processamento e na emissão dos voláteis. No entanto, a adição de LCC ao ligante asfáltico + PPA promoveu o aumento da penetração e a diminuição do ponto de amolecimento (Figura 2.14).

Com relação ao desempenho dos ligantes asfálticos levando em consideração a recuperação elástica e a compliância não-recuperável, FEE et al., (2010) avaliaram ligantes asfálticos modificados com PPA em comparação com o ligante asfáltico puro e o ligante asfáltico modificado com agentes melhoradores de adesividade (phosphat ester e amine) e com os polímeros SBS e Elvaloy. Os autores observaram que a adição de PPA reduziu a 
compliância não-recuperável e aumentou o percentual de recuperação dos ligantes asfálticos (Figura 2.16 e 2.17).

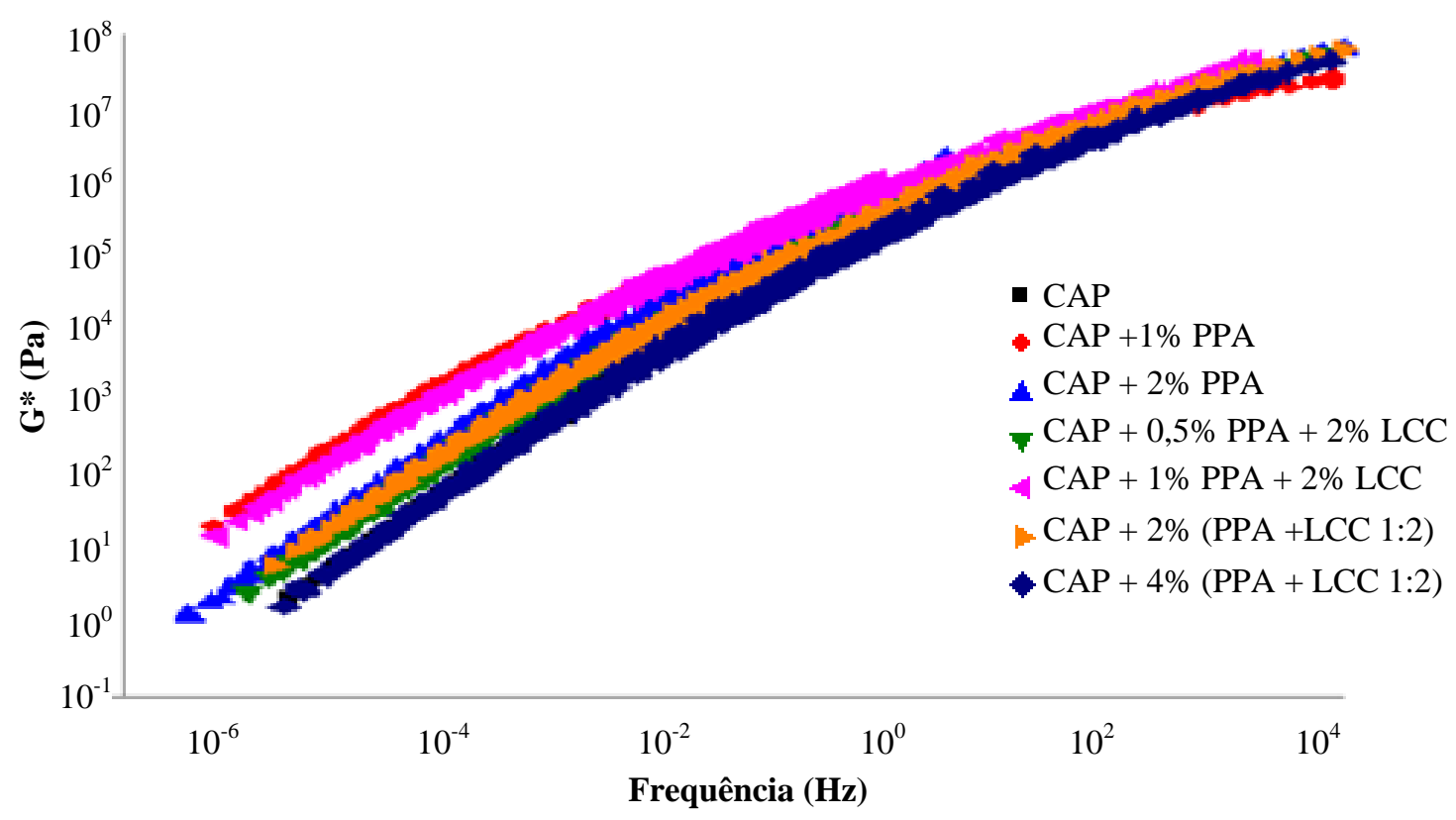

Figura 2.12 - Curva mestre do $G^{*}$ em função da frequência de carregamento dos ligantes asfálticos puros e modificados (FERNANDES, 2011)

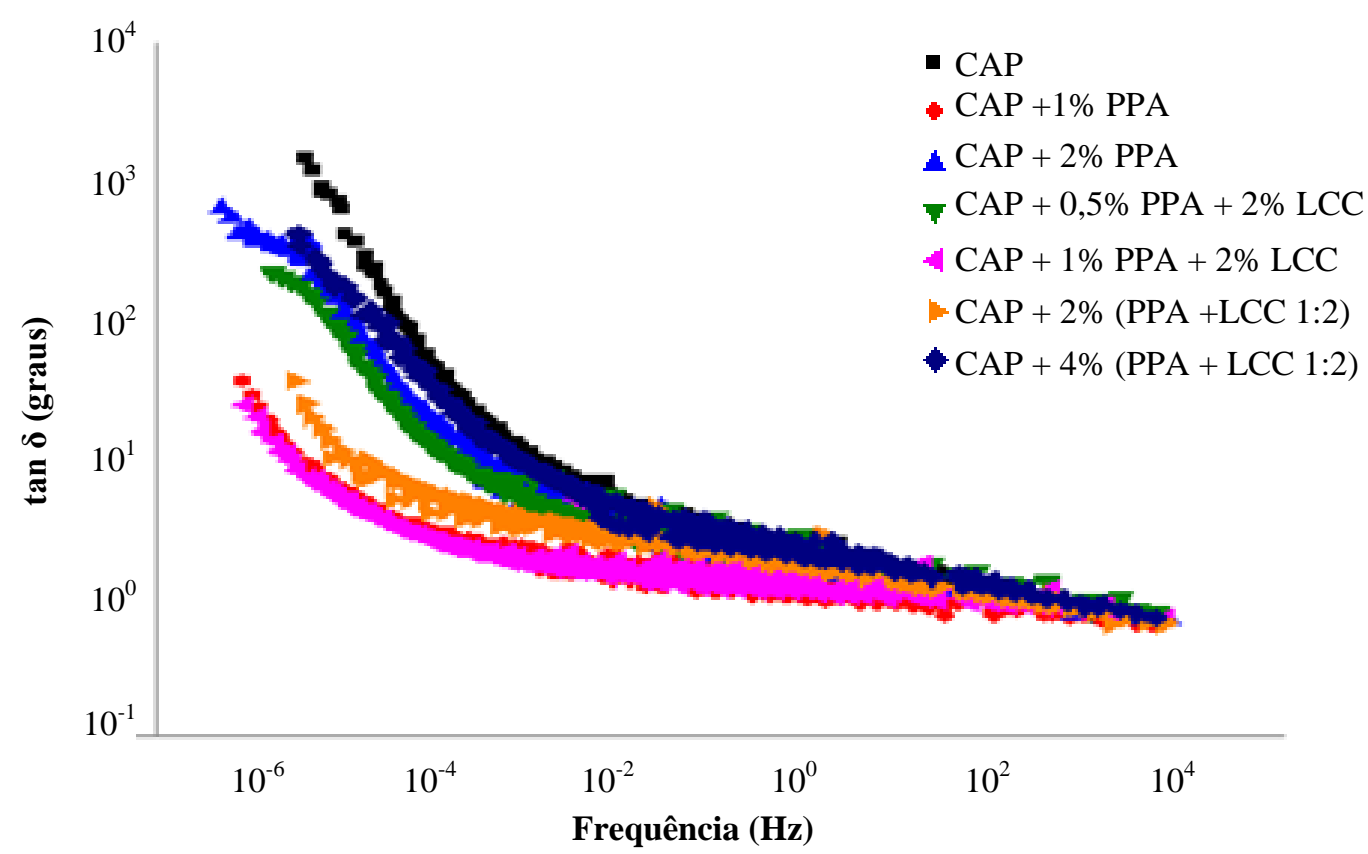

Figura 2.13 - Curva mestra da $\tan \delta$ em função da frequência de carregamento dos ligantes asfálticos puros e modificados (FERNANDES, 2011) 


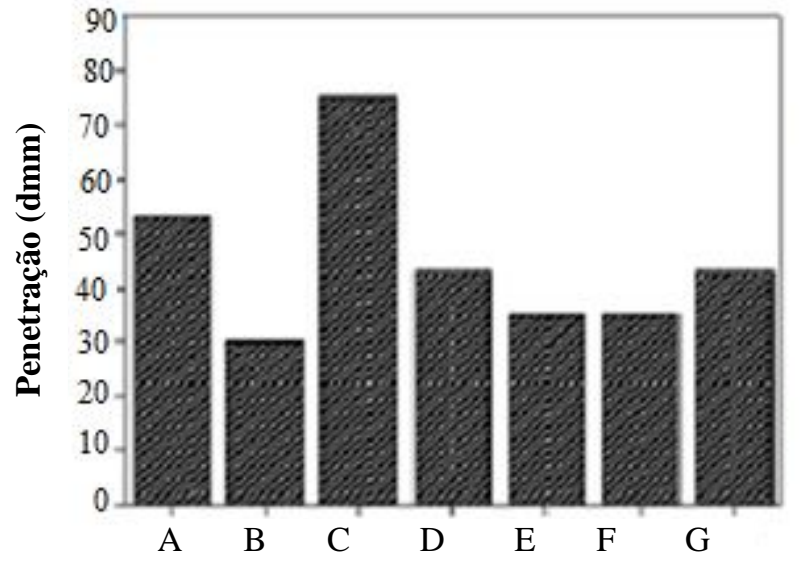

(a)

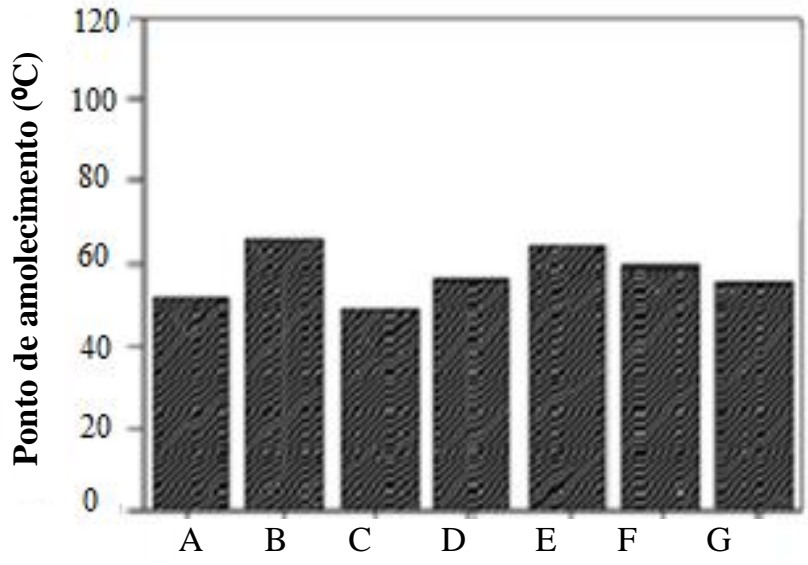

(b)

$\mathrm{A}-\mathrm{CAP}$

$\mathrm{B}-\mathrm{CAP}+1 \% \mathrm{PPA}$

$\mathrm{C}-\mathrm{CAP}+2 \% \mathrm{LCC}$

$\mathrm{D}-\mathrm{CAP}+0,5 \% \mathrm{PPA}+2 \% \mathrm{LCC}$

Figura 2.14 - Resultados da (a) penetração e do (b) ponto de amolecimento dos ligantes asfálticos puros e modificados (FERNANDES, 2011)

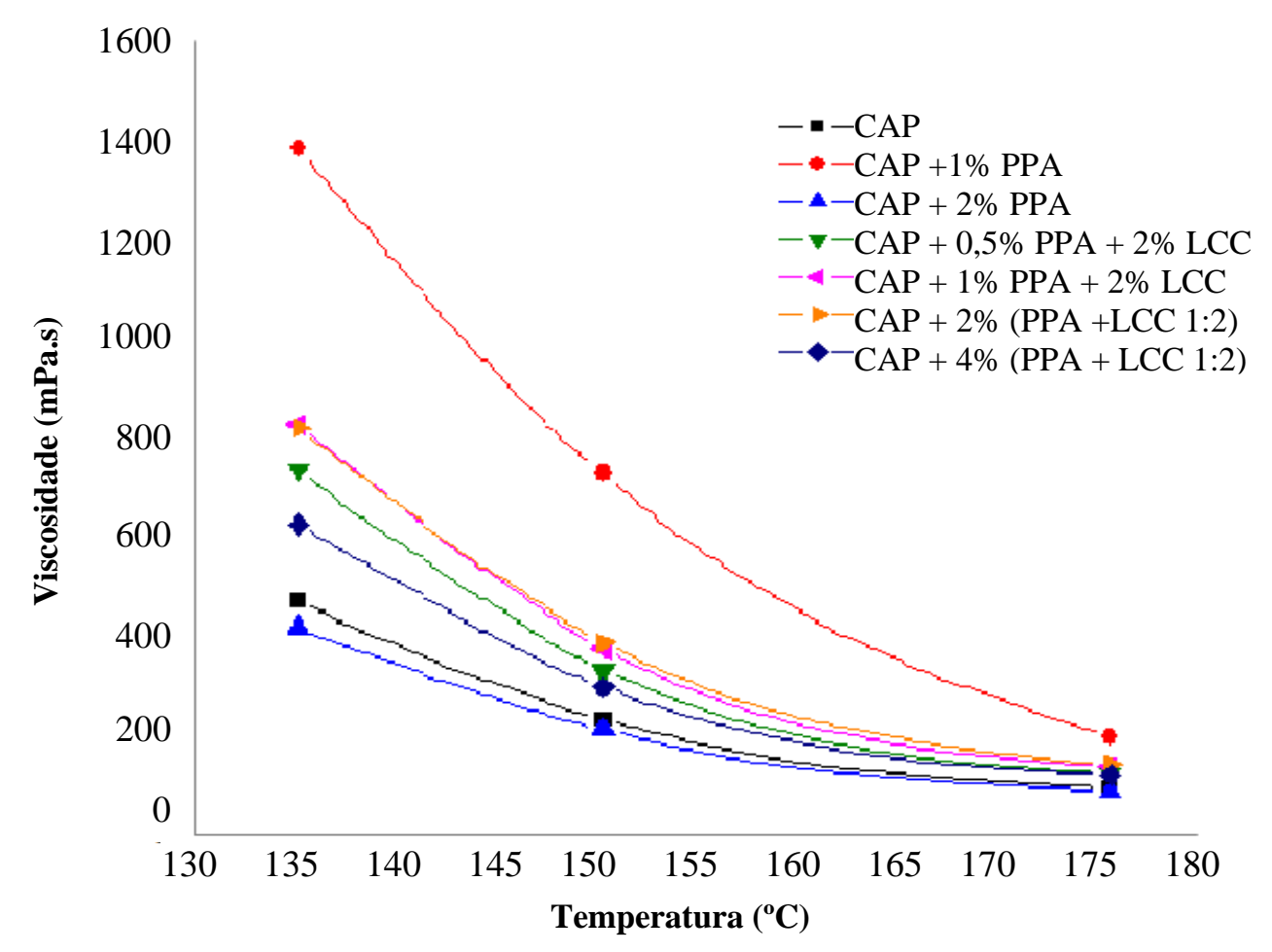

Figura 2.15 - Viscosidade em função da temperatura do ligante puro e dos ligantes modificados (FERNANDES, 2011)

Segundo Fee et al. (2010) a adição dos agentes melhoradores de adesividade ao ligante asfáltico + PPA aumentou o $\mathrm{J}_{\mathrm{nr}}$ e o ligante asfáltico modificado com $1 \%$ de SBS + 
0,3\% de PPA apresentou um $\mathrm{J}_{\mathrm{nr}}$ similar o ligante asfáltico modificado apenas com $2 \%$ de SBS (Figura 2.16). Os resultados do percentual de recuperação (Figura 2.17) identificam claramente o benefício causado pela adição de polímero Todos os ligantes asfálticos modificados com polímero apresentaram um percentual de recuperação maior que $30 \%$. O efeito da adição dos agentes melhoradores de adesividade foi inexpressivo em termos de percentual de recuperação e a adição de PPA (com ou sem o agente melhorador de adesividade) promoveu um pequeno aumento no percentual de recuperação (Figura 2.17).

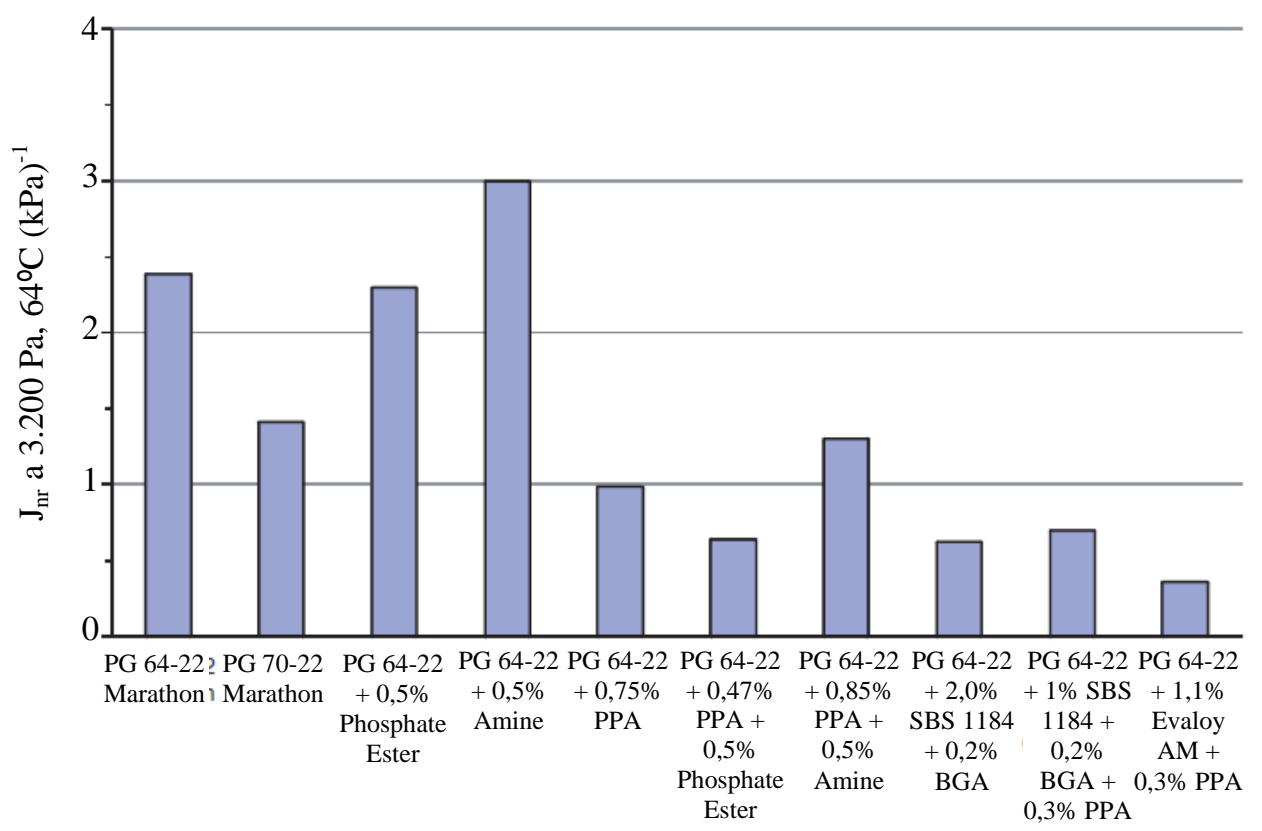

Figura 2.16 - Efeito do polímero, do PPA e do agente melhorador de adesividade na compliância nãorecuperável dos ligantes asfálticos (FEE et al., 2010)

Domingos (2011) avaliou o ligante asfáltico modificado apenas com PPA e os ligantes asfálticos modificados com diferentes polímeros (evaloy, borracha, SBS, EVA, Polietileno e SBR) aditivados ou não. As formulações dos ligantes asfálticos foram ajustadas para obter produtos com PG 76 - XX, partindo de um CAP de base com PG 64 - XX. Para manter o mesmo PG, os ligantes asfálticos modificados com polímero + PPA e borracha + PPA sofreram redução do percentual de polímero ou borracha adicionado, em relação aos seus correspondentes sem PPA. O autor observou que as formulações com PPA e polímero apresentaram uma menor viscosidade e penetração e um maior ponto de amolecimento quando comparadas ao ligante asfáltico modificado apenas com o respectivo polímero. Em relação à recuperação elástica e à compliância não-recuperável, o autor observou que a incorporação dos modificadores acarretou aumento da recuperação elástica, o que se traduz 
em uma maior recuperação do ligante asfáltico após a retirada da carga, e diminuição da compliância não recuperável, o que se reflete a um menor potencial à deformação permanente. No entanto, a presença do PPA só foi vantajosa, em termos de recuperação elástica e de compliância não-recuperável, para as formulações com os polímeros evaloy, borracha, Polietileno e SBR.

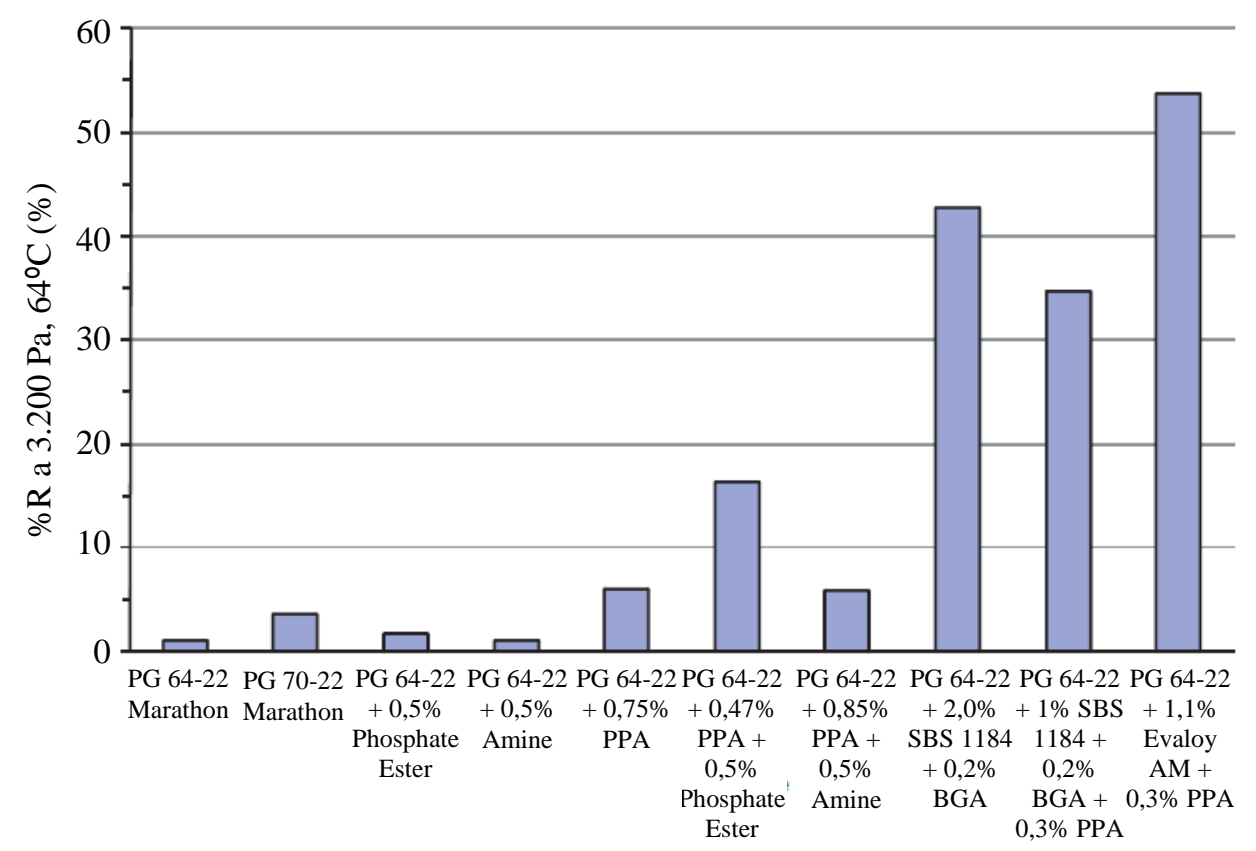

Figura 2.17 - Efeito do polímero, do PPA e do agente melhorador de adesividade no percentual de recuperação dos ligantes asfálticos (FEE et al., 2010).

Maldonado et al., (2012) avaliaram o desempenho de ligantes asfálticos modificados com SBS + PPA. Os autores utilizaram ligantes asfálticos (PG 58-28) de três fontes diferentes, modificados com PPA $(0,8 \%)$ e dois tipos diferentes de SBS: (i) SBS D1101 tradicional, e (ii) SBS MD 0243. A Tabela 2.4 apresenta o procedimento experimental utilizado pelos autores e os teores de SBS e PPA utilizados na preparação dos ligantes asfálticos modificados.

Os autores concluíram que o ligante asfáltico da Paramount é o mais sensível à adição de PPA, enquanto o ligante asfáltico da BP é o menos sensível. Os autores também observaram que a adição de PPA melhora significativamente os resultados de recuperação elástica, o grau de desempenho dos ligantes asfálticos sob altas temperaturas, sem afetar significativamente o grau de desempenho sob baixas temperaturas, além de diminuir a compliância não-recuperável (diminuindo o potencial a sofrer deformação permanente) e de 
aumentar o percentual de recuperação. A adição de PPA também diminui a separação de fases quando estocado entre o ligante asfáltico e o polímero SBS D1101. A partir dos resultados de MSCR, os autores observaram que o ligante asfáltico modificado com $2 \%$ de SBS $+0,8 \%$ de PPA apresenta melhor desempenho do que os ligantes asfálticos modificados apenas com $0,8 \%$ de PPA ou $3 \%$ de SBS.

Tabela 2.4 - Procedimento experimental e teores dos modificadores SBS e PPA (MALDONADO et al., 2012)

\begin{tabular}{|c|c|c|c|c|c|}
\hline \multirow{3}{*}{$\begin{array}{l}\text { Ligante asfáltico PG 58-28 } \\
\text { Tipo de SBS (Kraton) } \\
\text { \% PPA }\end{array}$} & \multicolumn{5}{|c|}{ Petróleo Paramount, BP e NuStar Energy } \\
\hline & \multicolumn{2}{|c|}{ MD243 } & \multicolumn{2}{|c|}{ D1101 } & \multirow{2}{*}{$\begin{array}{c}\text { Nenhum } \\
0,8\end{array}$} \\
\hline & 0,8 & - & 0,8 & - & \\
\hline$\% \mathrm{SSB}$ & 2 & 3 & 2 & 3 & - \\
\hline Cross-Linking, \% enxofre & - & - & 0,04 & 0,06 & - \\
\hline MSCR, \%R a 3.200Pa, 64 ${ }^{\circ} \mathrm{C}$ & $\mathrm{x}$ & $\mathrm{x}$ & $\mathrm{x}$ & $\mathrm{X}$ & $\mathrm{x}$ \\
\hline MSCR, Jnr a 3.200Pa, $64 \circ \mathrm{C}$ & $\mathrm{x}$ & $\mathrm{x}$ & $\mathrm{x}$ & $\mathrm{X}$ & $\mathrm{x}$ \\
\hline Recuperação elástica a $25^{\circ} \mathrm{C}$ & $\mathrm{x}$ & $\mathrm{x}$ & $\mathrm{x}$ & $\mathrm{X}$ & $\mathrm{x}$ \\
\hline Grau de desempenho (PG) & $\mathrm{x}$ & $\mathrm{x}$ & $\mathrm{x}$ & $\mathrm{X}$ & $\mathrm{x}$ \\
\hline Grau de desempenho contínuo & $\mathrm{x}$ & $\mathrm{x}$ & $\mathrm{x}$ & $\mathrm{X}$ & $\mathrm{x}$ \\
\hline Estabilidade à estocagem & - & - & $\mathrm{x}$ & $\mathrm{X}$ & - \\
\hline
\end{tabular}

Maldonado et al. (2012) também avaliaram o efeito da adição de PPA na resistência à fadiga de misturas asfálticas. Para determinar isso, os autores realizaram um estudo de fadiga à deformação controlada, realizando o ensaio de BBF (Bending Beam Fatigue). Três ligantes asfálticos foram utilizados no preparo das misturas asfálticas, conforme indicado na Tabela 2.5. Os autores não observaram nenhuma mudança significativa na resistência à fadiga das misturas asfálticas devida à redução do teor de SBS.

Tabela 2.5 - Procedimento experimental desenvolvido para avaliar o efeito da redução de polímero na resistência à fadiga de misturas asfálticas (MALDONADO et al., 2012)

\begin{tabular}{ccccccc}
\hline Ligante asfáltico & \% SBS & $\begin{array}{c}\text { temperatura } \\
\text { de mistura }\end{array}$ & $\begin{array}{c}\text { tempo de } \\
\text { mistura }\end{array}$ & $\begin{array}{c}\text { ligante asfáltico } \\
\text { de base }\end{array}$ & $\begin{array}{c}\text { \% } \\
\text { PPA }\end{array}$ & $\begin{array}{c}\text { Cross- } \\
\text { Linking }\end{array}$ \\
\hline Ligante asfáltico 1 & 4,00 & 188 & 2 & & & Sim \\
Ligante asfáltico 2 & 3,00 & 200 & 6 & Nustar & $0.5 \%$ & \\
Ligante asfáltico 3 & 2,33 & 200 & 6 & PG 58-28 & & Não \\
\hline
\end{tabular}


Muitos pesquisadores estudam a influência do PPA nas propriedades das misturas asfálticas e afirmam que o ácido promove um aumento da resistência à compressão, melhorando as condições do pavimento de suportar as solicitações provocadas pelo tráfego, que podem provocar defeitos no pavimento. Bennert e Martin (2012) observaram que misturas asfálticas compostas com ligante asfáltico modificado com SBS+PPA e compostas com ligante asfáltico modificado apenas com SBS forneceram resistências à fadiga equivalentes (Figura 2.18). Resistências equivalentes à deformação permanente também foram observadas para estas misturas asfálticas (Figura 2.19), embora os resultados do ensaio MSCR indicassem que o ligante asfáltico modificado apenas com SBS apresentou maior resistência à deformação permanente mesmo em temperatura mais baixa (Figura 2.20).

Bennert et al. (2012) também constataram que a relação de resistências à tração das misturas compostas com ligante asfáltico modificado com SBS+PPA é maior que a obtida para a mistura composta com ligante asfáltico modificado apenas com SBS, indicando que a primeira mistura apresenta maior resistência ao dano por umidade.

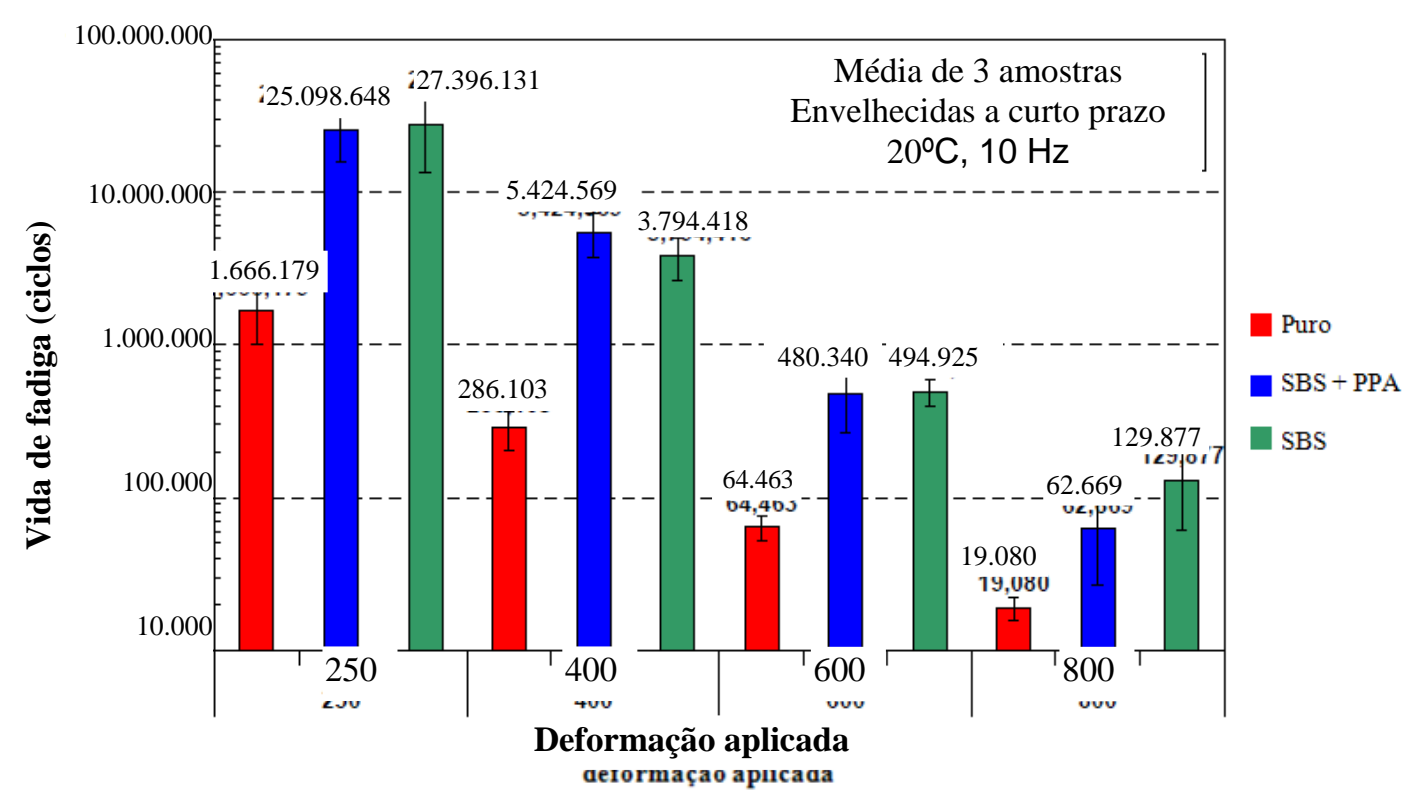

Figura 2.18 - Resultados de vida de fadiga de misturas asfálticas para amostras de vigas envelhecidas a curto prazo (BENNERT et al., 2012)

Arnold et al. (2012) verificaram que a sensibilidade à umidade tanto de ligantes asfálticos como de mástiques diminuiu com o aumento da proporção de ácido, porém apenas para teores abaixo de $0,7 \%$. Em níveis mais altos de PPA, a sensibilidade à umidade dos 
ligantes asfálticos e dos mástiques aumentou com o aumento da proporção de PPA (Figura 2.21). Os autores também constataram que misturas asfálticas compostas com agregados tratados com cal e ligante asfáltico modificado com ácido polifosfórico não mostraram potencial de dano induzido pela água.

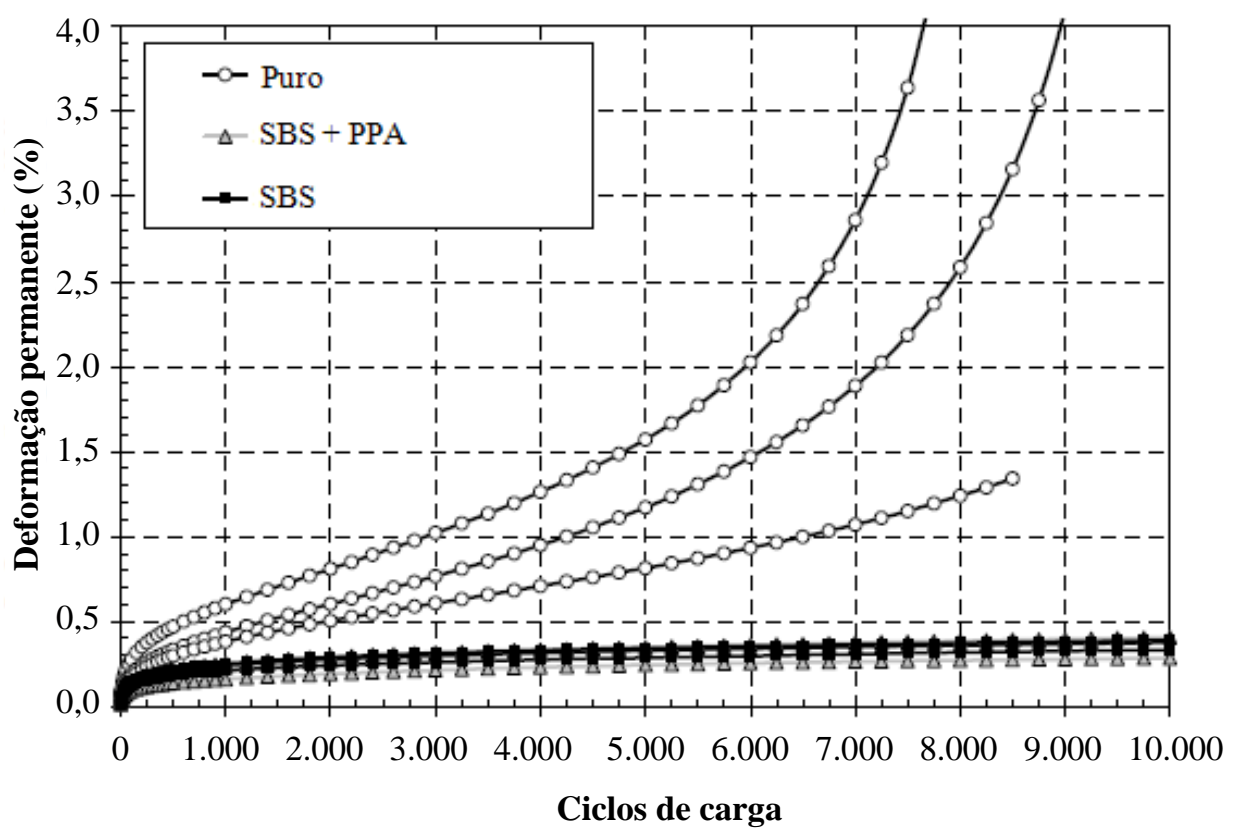

Figura 2.19 - Resultados de deformação permanente sob carga repetida RTFOT (BENNERT et al., 2012)

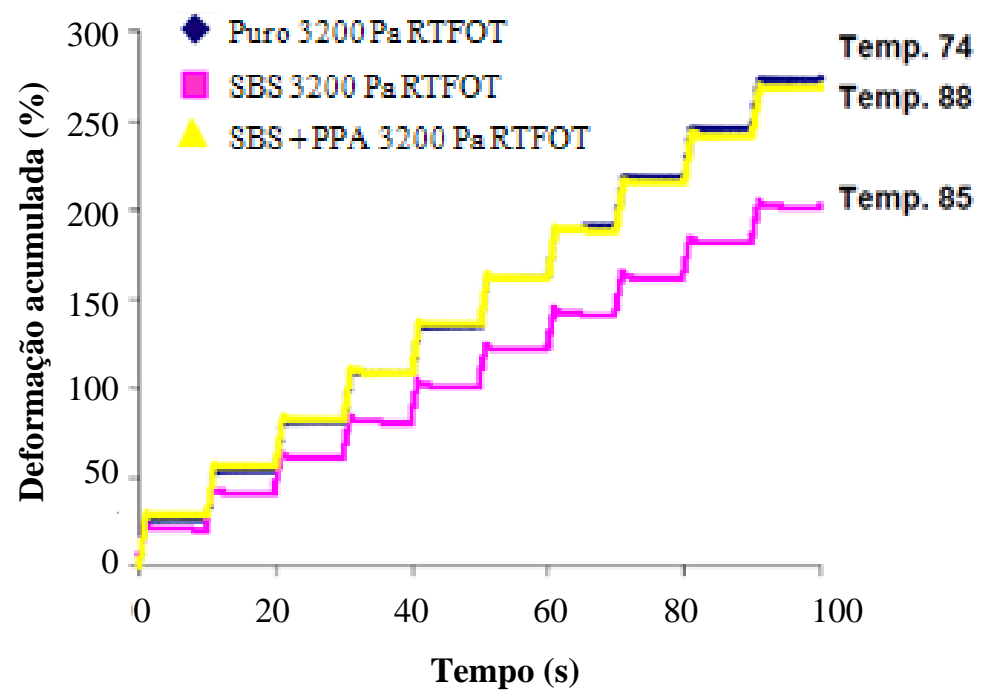

Figura 2.20 - Resultados de MSCR, a 3.200Pa, dos ligantes asfálticos envelhecidos no RTFOT (BENNERT et al., 2012) 


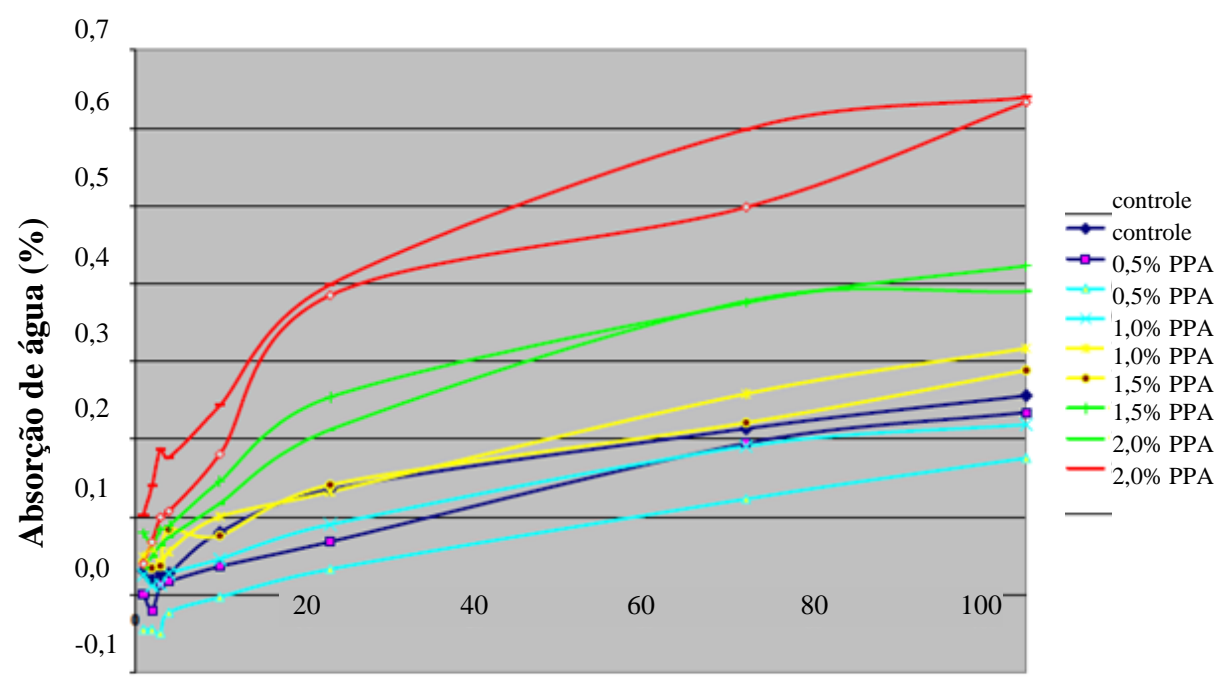

Dias sob imersão

Figura 2.21 - Absorção de água em mástiques (ARNOLD et al., 2012)

Grande (2011) avaliou os efeitos do ácido polifosfórico nas propriedades mecânicas e suscetibilidade à umidade de misturas asfálticas densas e observou que o aumento da concentração de PPA melhora a rigidez, a flexibilidade e a suscetibilidade ao dano por umidade e aumenta a resistência à tração. Maldonado e Fee (2008) observaram que, em misturas asfálticas com agregados do tipo granítico, a adição de PPA promove aumento da adesão e da resistência à umidade e, em misturas asfálticas com agregados calcários, a adição de baixos teores de PPA (menores que 1\%) melhora o desempenho ao dano por umidade das misturas asfálticas. Fernandes (2011) observou que a adição de 1,0\% de PPA aumentou o teor de projeto em $0,5 \%$ e as misturas compostas com ligantes asfálticos modificados com PPA apresentaram uma maior relação de resistências à tração e uma melhor adesividade com os agregados minerais (Tabela 2.6).

Tabela 2.6 - Resultados do ensaio Lotman modificado (FERNANDES, 2011)

\begin{tabular}{|c|c|c|c|c|c|c|c|}
\hline \multirow[b]{3}{*}{$\begin{array}{c}\text { Mistura } \\
\text { Asfáltica/agregado }\end{array}$} & \multicolumn{6}{|c|}{ Resistência à Tração (RT) } & \multirow[b]{3}{*}{$\begin{array}{r}\text { RRT } \\
(\%) \\
\end{array}$} \\
\hline & \multicolumn{3}{|c|}{ Não Condicionado } & \multicolumn{3}{|c|}{ Condicionado } & \\
\hline & $\begin{array}{l}\text { Média } \\
\text { (MPa) }\end{array}$ & $\begin{array}{c}\text { Desvio } \\
\text { Padrão } \\
\text { (MPa) }\end{array}$ & $\begin{array}{l}\mathrm{CV} \\
(\%)^{*}\end{array}$ & $\begin{array}{l}\text { Média } \\
\text { (MPa) }\end{array}$ & $\begin{array}{c}\text { Desvio } \\
\text { Padrão } \\
\text { (MPa) }\end{array}$ & $\begin{array}{l}\text { CV } \\
(\%)\end{array}$ & \\
\hline CAP puro & 0,66 & 0,05 & 8 & 0,50 & 0,06 & 11 & 76 \\
\hline $\mathrm{CAP}+2 \% \mathrm{LCC}$ & 0,65 & 0,05 & 8 & 0,76 & 0,06 & 9 & 86 \\
\hline $\mathrm{CAP}+1 \% \mathrm{PPA}$ & 0,63 & 0,04 & 5 & 0,74 & 0,05 & 4 & 85 \\
\hline
\end{tabular}


O ácido polifosfórico tem sido defendido pela indústria como um redutor da proporção de polímero, aparentemente com motivações econômicas, já que o custo do ácido é menor que o do polímero. O ácido polifosfórico parece preservar algumas características esperadas de um ligante asfáltico modificado com uma determinada proporção de polímero mesmo quando esta proporção é reduzida. Estudos têm mostrado o impacto da combinação do ácido polifosfórico com polímeros sintéticos: ele permite reduzir a proporção de polímero adicionada ao ligante asfáltico, o que provoca redução da viscosidade, mas proporcionando propriedades reológicas tão adequadas quanto às do ligante asfáltico modificado apenas com o polímero (MARTIN e BAUMGARDNER, 2006), além de melhorar a trabalhabilidade da mistura asfáltica e a estocagem do ligante asfáltico. A patente US 2006/0250886 indica que a combinação do asfalto-borracha com ácido polifosfórico permite melhorar tanto as propriedades reológicas do ligante asfáltico quanto das misturas asfálticas. O desafio dos pesquisadores e construtores é saber se a adição do ácido prejudicará ou não o desempenho da mistura asfáltica a longo prazo.

O Estado de Luisiana, nos Estados Unidos, tem utilizado ligantes asfálticos modificados por polímero em larga escala no seu sistema de pavimentação. As misturas asfálticas utilizadas naquele Estado são produzidas com uma grande variedade de agregados minerais que vão desde calcário até agregados graníticos. O teor de asfaltenos dos ligantes asfálticos fornecidos ao Estado varia bastante. Os pavimentos produzidos com ligantes asfálticos modificados com PPA não apresentam nenhum defeito até a presente data (ABADIE e D’ANGELO, 2012). De 2000 a 2005, o Estado de Arkansas, Estados Unidos, reconstruiu grande parte das rodovias interestaduais utilizando ligantes asfálticos de PG 7622. Para atingir este grau de desempenho, o ligante asfáltico foi modificado com PPA + SBS.

Segundo o Departamento de Transporte do Estado de Arkansas, em 1999, 37\% do sistema rodoviário apresentava um índice de rugosidade (IRI) ruim e 33\% apresentava um IRI medíocre. Em 2006, depois da reconstrução, mais de 73\% do sistema rodoviário interestadual apresentava boa condição. O sistema de gerência de pavimentos do Estado de Arkansas prevê que, em 2016, 53\% dos pavimentos estarão em boas condições, sem que nenhum trabalho adicional seja realizado. Desta forma, o ligante asfáltico modificado com PPA + SBS apresentará um bom desempenho por mais de 10 anos, com nenhum defeito no sistema rodoviário do Estado relacionado ao ligante asfáltico (WESTERMAN e D’ANGELO, 2012). 


\section{CAPÍTULO 3. MATERIAIS E MÉTODOS}

Os materiais e ensaios utilizados no desenvolvimento desta pesquisa estão brevemente descritos neste capítulo. Os procedimentos de envelhecimento a curto e longo prazo são apresentados. É destacado o reômetro de cisalhamento dinâmico, o qual é utilizado na obtenção de importantes propriedades reológicas como a rigidez e elasticidade dos ligantes asfálticos, bem como na avaliação do desempenho dos ligantes asfálticos quanto a deformação permanente (parâmetros $\% \mathrm{R}$ e $\mathrm{J}_{\mathrm{nr}}$ ) e a trincas por fadiga $\left(\mathrm{a}_{\mathrm{f}}\right)$. Também são apresentados neste capítulo os ensaios: (i) caracterização da composição química dos ligantes asfálticos; (ii) viscosidade rotacional; (iii) determinação da temperatura alta do grau de desempenho; (iv) varredura de frequência, que envolve a obtenção das propriedades de rigidez $\left(\mathrm{G}^{*}\right)$ e elasticidade $(\delta)$ dos ligantes asfálticos, (v) fluência e recuperação (MSCR), envolvendo os parâmetros percentual de recuperação (\%R), compliância não-recuperável ( $\left.\mathrm{J}_{\mathrm{nr}}\right)$ e o parâmetro $\mathrm{J}_{\mathrm{nt} \text {,diff }}$ e (vi) ensaio acelerado de fadiga de ligantes asfálticos, utilizado para avaliar o comprimento da trinca $\left(\mathrm{a}_{\mathrm{f}}\right)$ na ruptura por fadiga.

\subsection{MATERIAIS}

Dois ligantes asfálticos classificados de penetração 50/70 foram utilizados no preparo das amostras modificadas com PPA. Os ligantes asfálticos foram fornecidos por duas refinarias da Petrobras: LUBNOR (predominantemente aromáticos-naftênicos), localizada em Fortaleza, Ceará e REDUC (predominantemente aromático), localizada em Duque de Caxias, Rio de Janeiro. O PPA com designação comercial de Innovalt E200, foi fornecido pela Innophos Inc e as proporções utilizadas foram: 0,0, 0,5, 1,0, 1,5 e 2,0\%

\subsubsection{Preparo das amostras}

O ligante asfáltico e o PPA foram misturados em um misturador de baixo cisalhamento da marca Fisatom, a uma temperatura de $130^{\circ}$, durante 30 minutos. As proporções dos ligantes asfálticos e PPA utilizadas para produzir os ligantes asfálticos modificados e os respectivos graus de desempenho estão apresentadas na Tabela 3.1. 
Tabela 3.1- Formulação e PG dos ligantes asfálticos

\begin{tabular}{cccc}
\hline amostra & PG & ligante asfáltico (\%) & PPA (\%) \\
\hline LUBNOR1 & $70-X X$ & 100.0 & 0.0 \\
LUBNOR2 & $76-X X$ & 99.5 & 0.5 \\
LUBNOR3 & $76-X X$ & 99.0 & 1.0 \\
LUBNOR4 & $88-X X$ & 98.5 & 1.5 \\
LUBNOR5 & $88-X X$ & 98.0 & 2.0 \\
REDUC1 & $64-X X$ & 100.0 & 0.0 \\
REDUC2 & $70-X X$ & 99.5 & 0.5 \\
REDUC3 & $70-X X$ & 99.0 & 1.0 \\
REDUC4 & $70-X X$ & 98.5 & 1.5 \\
REDUC5 & $82-X X$ & 98.0 & 2.0 \\
\hline
\end{tabular}

\subsection{PROCEDIMENTOS DE ENVELHECIMENTO}

\subsubsection{Envelhecimento termo-oxidativo em estufa de filme rotativo (RTFOT)}

O ligante asfáltico foi envelhecido utilizando uma estufa de filme rotativo (Roling Thin Film Oven Test-RTFOT). Este método simula o envelhecimento a curto prazo que o material pode sofrer durante a usinagem a $150{ }^{\circ} \mathrm{C}$ de acordo com a norma ASTM D 2872-97. Tal efeito é verificado por meio das variações sofridas nas propriedades reológicas dos ligantes asfálticos puro e modificados após o envelhecimento em relação ao ligante asfáltico virgem.

Neste ensaio, uma película fina de ligante asfáltico de $35 \mathrm{~g}$ é continuamente girada dentro de um recipiente de vidro apropriado a $163{ }^{\circ} \mathrm{C}$ por 85 minutos, com uma injeção de ar a cada 3 a 4 segundos. Em seguida são resfriadas à temperatura ambiente e depois pesadas para determinação da perda de massa.

\subsubsection{Envelhecimento termo-oxidativo em sistema de vaso de pressão (PAV)}

O ligante asfáltico foi testado utilizando um vaso de pressão (Pressure Aging Vessel $P A V)$. Este método simula o endurecimento oxidativo que ocorre no ligante asfáltico ao longo da vida útil do pavimento. O envelhecimento a longo prazo é verificado por meio das variações entre as propriedades reológicas do ligantes asfálticos virgens e envelhecidos.

Como o asfalto aplicado do campo deve ser primeiramente usinado, esse ensaio no PAV é precedido do ensaio na estufa RTFOT. Desta forma, $50 \mathrm{~g}$ da amostra retirada após o ensaio no RTFOT são colocadas em placas rasas de aço inox e envelhecidas à $100^{\circ} \mathrm{C}$ por $20 \mathrm{~h}$ em 
um vaso pressurizado com 2,10 MPa de ar. Em seguida, a amostra é colocada em uma estufa a vácuo para desarear.

\subsection{REÔMETRO DE CISALHAMENTO DINÂMICO (DSR)}

As determinações dos parâmetros reológicos como módulo complexo $\left(\mathrm{G}^{*}\right)$ e ângulo de fase $(\delta)$ são realizadas por meio do rêometro de cisalhamento dinâmico, empregando regime oscilatório. Nesse equipamento, a amostra é colocada entre duas placas paralelas, das quais uma gira e a outra se mantém fixa, sendo submetida a ciclos de tensão ou deformação senoidais, dependendo do tipo de carregamento. Tanto $\mathrm{G}^{*}$ como $\delta$ são funções do tempo de carregamento e da temperatura. $O$ ângulo de fase $(\delta)$ possibilita avaliar a razão entre a resposta elástica e a viscosa durante o processo de cisalhamento, enquanto o módulo complexo $\left(\mathrm{G}^{*}\right)$ indica a rigidez do material. $\mathrm{O} \mathrm{G}^{*}$ é definido como a razão entre a tensão máxima de cisalhamento e a deformação máxima (Equação 3.1). Contém um componente elástico (G'), designado como o módulo de armazenamento, e um componente viscoso (G”), designado como módulo de perda.

$$
G^{*}=\frac{\tau_{\operatorname{máx}}}{\gamma_{\operatorname{máx}}}
$$

O módulo de armazenamento indica a parcela de energia proveniente da tensão aplicada, temporariamente armazenada durante o teste, e que pode ser recuperada posteriormente. G' é definido matematicamente pela equação 3.2:

$$
G^{\prime}=G^{*} \cdot \cos \delta=\left(\frac{\tau_{\text {máx }}}{\gamma_{\text {máx }}}\right) \cdot \cos \delta
$$

O módulo de perda indica a parcela de energia utilizada para dar início ao escoamento e que foi transferida de maneira irreversível em forma de calor, sendo definido matematicamente pela equação 3.3:

$$
G^{\prime \prime}=G^{*} \cdot \operatorname{sen} \delta=\left(\frac{\tau_{\text {máx }}}{\gamma_{\text {máx }}}\right) \cdot \operatorname{sen} \delta
$$


A Figura 3.1 apresenta os parâmetros $G^{*}$ e $\delta$ obtidos no ensaio com o DSR. A forma esquemática da aplicação de carga, seja à tensão controlada ou à deformação controlada, está representada Figura 3.1(a). A resposta em forma de deformação cisalhante do ligante asfáltico está defasada por um período tempo $(\Delta \mathrm{t})$ em relação à tensão aplicada na amostra conforme indicado na Figura 3.1(b). Esse intervalo de tempo $(\Delta \mathrm{t})$ representa o atraso na deformação obtida e ao ser multiplicado pela frequência angular (w) nos dá a fase em atraso representada pelo ângulo de fase $(\delta)$.
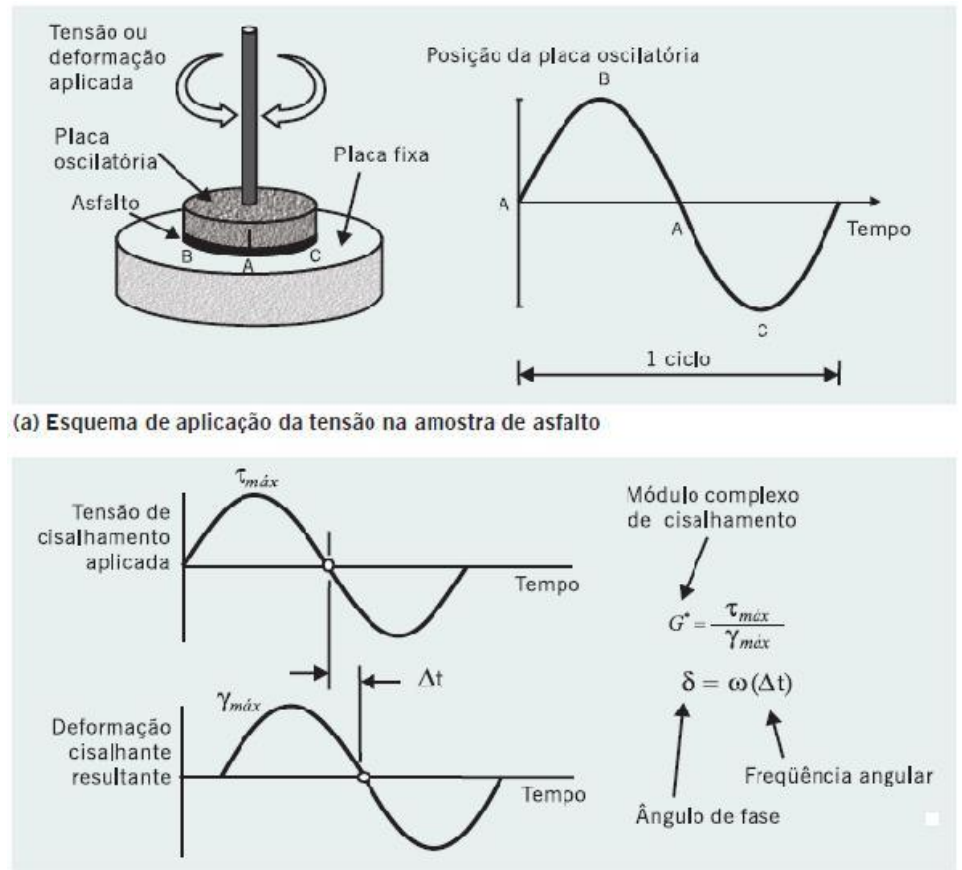

(b) Defasagem entre tensão e deformação

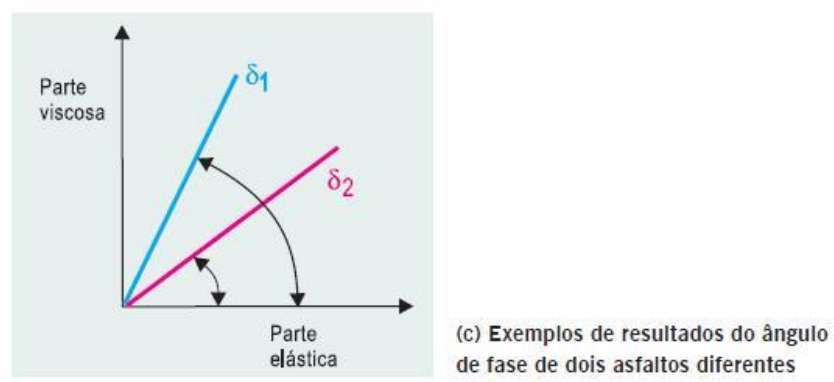

Figura 3.1- Representação gráfica do modo de aplicação das tensões ou deformações cisalhantes, dos parâmetros e resultados obtidos com o DSR (BERNUCCI et al., 2007)

Quando não houver atraso entre a tensão aplicada e a deformação obtida, $\delta$ é igual a $0^{\circ}$. Isso acontece para materiais completamente elásticos. Nesse caso o módulo de perda é zero $\left(G^{\prime \prime}=0\right)$ e, consequentemente, o módulo complexo é igual ao módulo de armazenamento. Quando o material é totalmente viscoso, a deformação obtida a partir da tensão aplicada é 
completamente defasada. Nesse caso $\delta$ é igual a $90^{\circ}$ e seu módulo de armazenamento é zero $\left(G^{\prime}=0\right)$, consequentemente, o módulo complexo é igual ao módulo de perda, $G^{*}=G^{\prime}$ (BRINGEL, 2007).

Para materiais viscoelásticos, como é o caso do ligante asfáltico, o ângulo de fase $\delta$ varia entre $0^{\circ}$ e $90^{\circ}$. Quanto mais próximo de $0^{\circ}$ for o ângulo de fase $(\delta)$ da amostra de ligante, mais elástica será o material. O ângulo de fase varia tanto com o tipo de ligante como com a temperatura de ensaio. A Figura 3.1(c) representa um mesmo ligante asfáltico em diferentes temperaturas, onde a temperatura 2 é menor que a temperatura 1 . O ângulo de fase tende a $90^{\circ} \mathrm{em}$ altas temperaturas e, em baixas temperaturas, tende a $0^{\circ}$ (FAXINA, 2006; BRINGEL, 2007). A Figura 3.1(c) também pode representar dois ligantes asfálticos distintos, na mesma temperatura de ensaio, onde $\delta_{2}<\delta_{1}$, mostrando que o ligante asfáltico 1 é mais viscoso que o 2 (BERNUCCI et al., 2007).

O reômetro de cisalhamento pode ser tanto de tensão controlada como de deformação controlada. No modo de tensão controlada há a aplicação de uma tensão fixa e se mede a deformação correspondente obtida. No modo de deformação controlada, aplica-se uma tensão variável correspondente a uma deformação fixa e devidamente especificada no início do ensaio.

\subsection{MÉTODOS DE ENSAIO}

\subsubsection{Cromatografia de camada fina com detecção por ionização de chama}

As frações de saturados, aromáticos, resinas e asfaltenos (SARA) foram determinadas por meio da cromatografia de camada fina utilizando o equipamento IATROSCAN MK-6, com sistema de detecção FID, fluxos de $\mathrm{H}_{2}$ de $160 \mathrm{~mL} / \mathrm{min}$ e fluxo de ar de $2 \mathrm{~mL} / \mathrm{min}$, sensibilidade de $50 \mathrm{mV}$ e velocidade de varredura de $30 \mathrm{~s} / \mathrm{rod}$.

Neste procedimento, alíquotas de $1 \mu \mathrm{L}$ foram aplicadas nos rods de quartzo revestidos por fina camada de sílica. O suporte contendo os rods foi colocado sequencialmente em cubas contendo três solventes de diferentes polaridades: n-hexano, tolueno e diclorometano: metanol na proporção de 57:3. Os tempos de eluição em cada cuba foram de aproximadamente 40, 15 e 3 minutos, respectivamente. Depois de cada eluição, o suporte contendo os rods foi colocado em forno por $2 \min$ à $150{ }^{\circ} \mathrm{C}$ para completa evaporação dos solventes. 
O índice de instabilidade coloidal (Ic) (GAESTEL et al.,1971) é utilizado para caracterizar o equilíbrio coloidal entre fases e é calculado de acordo com a equação 3.1. O índice de instabilidade coloidal varia entre 0,5 e 2,7 .

$I_{C}=\frac{S+A}{R+A r}$

Onde, Ic = Índice de Instabilidade Coloidal; $\mathrm{S}=$ Saturados; $\mathrm{A}=$ Asfaltenos; $\mathrm{R}=$ Resinas e $\mathrm{Ar}=$ Aromáticos.

\subsubsection{Determinação da viscosidade rotacional e da temperatura de compactação e usinagem}

As viscosidades absolutas dos ligantes asfálticos puros e modificados foram determinadas utilizando o viscosímetro Brookfield modelo DVII+Pro acoplado a um controlador de temperatura THERMOSEL, utilizando o spindle 21. A viscosidade é medida a partir do torque necessário para rodar o spindle imerso em uma amostra de ligante asfáltico a uma velocidade constante. O ensaio foi realizado nas temperaturas de 135, 144, 150, 163 e $175^{\circ} \mathrm{C}$. As viscosidades finais de cada ligante asfáltico foram calculadas pela média dos valores obtidos em todas as réplicas. As temperaturas, as velocidades de rotação e a taxa de cisalhamento estão indicadas na Tabela 3.2. A escolha destas velocidades foi feita com o objetivo de realizarem medições dentro dos limites de porcentagem de torque (10 a 98\%) estipulados pela norma ASTM D4402.

Tabela 3.2 - Dados do ensaio de viscosidade rotacional

\begin{tabular}{ccc}
\hline Temperatura ( $\left.{ }^{\mathbf{O}} \mathbf{C}\right)$ & Velocidade $(\mathbf{R P M})$ & Taxa de cisalhamento $\left(\mathbf{s}^{-\mathbf{1}}\right)$ \\
\hline 135 & 10 & 9 \\
144 & 15 & 14 \\
150 & 20 & 19 \\
163 & 30 & 28 \\
177 & 50 & 47 \\
\hline
\end{tabular}


As temperaturas de compactação e de usinagem dos ligantes asfálticos podem ser determinadas a partir dos resultados de viscosidade rotacional. Estas temperaturas são estimadas com base em intervalos de temperaturas, a fim de normalizar o efeito da rigidez do ligante asfáltico nas propriedades volumétricas da mistura asfáltica. Segundo a especificação Superpave, a temperatura de usinagem é aquela na qual o ligante asfáltico apresenta uma viscosidade de 0,17 \pm 0,02 Pa.s e a temperatura de compactação é aquela em que o ligante asfáltico apresenta uma viscosidade de 0,28 \pm 0,03 Pa.s (Figura 3.2).

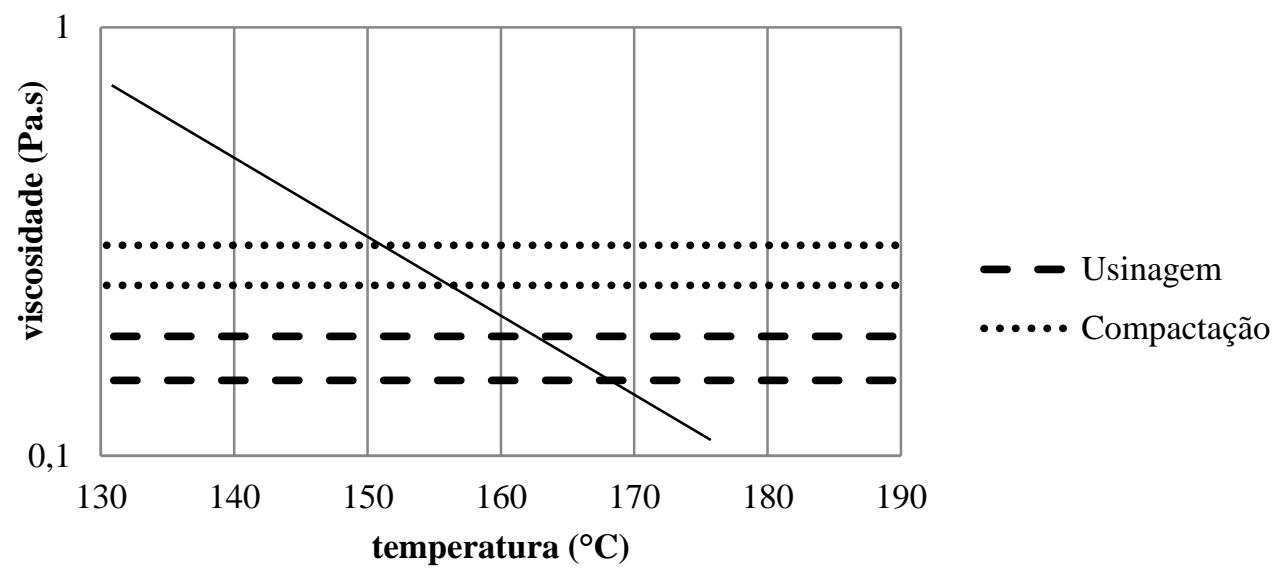

Figura 3.2 - Determinação das temperatura de usinagem e compactação (TUC)

\subsubsection{Varredura de frequência}

Anteriormente à realização dos ensaios de varredura de frequência, as amostras foram submetidas à varredura de tensão, nas temperaturas de ensaio, para a determinação dos valores de tensão que solicitariam o material dentro de faixa de viscoelasticidade linear. As amostras foram então submetidas a uma varredura de frequência de 0,1 a $100 \mathrm{rad} / \mathrm{s}$. O experimento é dividido em duas etapas: (i) a primeira é realizada nas temperaturas de 4, 16, 28 e $40^{\circ} \mathrm{C}$ (baixas temperaturas) e (ii) a segunda nas temperaturas de $52,64,76$ e $88^{\circ} \mathrm{C}$ (altas temperaturas). As amostras foram moldadas em um molde de silicone com aproximadamente $2 \mathrm{~mm}$ de espessura e $8 \mathrm{~mm}$ de diâmetro para a primeira etapa (temperaturas abaixo de $40^{\circ} \mathrm{C}$ ) e $1 \mathrm{~mm}$ de espessura e $25 \mathrm{~mm}$ de diâmetro para a segunda etapa (temperaturas acima de $40^{\circ} \mathrm{C}$ ). As amostras foram testadas com spindles de placas paralelas e diâmetros de, respectivamente, 8 e $25 \mathrm{~mm}$. Neste ensaio as propriedades de rigidez $\left(\mathrm{G}^{*}\right)$ e elasticidade $(\delta)$ dos ligantes asfálticos são monitoradas. 


\subsubsection{Grau de desempenho (PG)}

O grau de desempenho das amostras foi obtido utilizando Reômetro de Cisalhamento Dinâmico AR 2000ex - TA Instruments ${ }^{\circledR}$, onde foi realizada uma varredura do parâmetro $\mathrm{G}^{*} / \operatorname{sen} \delta$ em função da temperatura $\left(52,58,64,70,76,82\right.$ e $\left.88^{\circ} \mathrm{C}\right) . \mathrm{O}$ PG corresponde à temperatura múltipla de 6 imediatamente inferior à temperatura em que $\mathrm{G}^{*} / \mathrm{sen} \delta$ é igual a 1,0 $\mathrm{kPa}$, de acordo com o novo critério da especificação Superpave.

\subsubsection{Multiple Stress Creep and Recovery (MSCR)}

O ensaio foi realizado utilizando o Reômetro de Cisalhamento Dinâmico AR 2000ex TA Instruments ${ }^{\circledR}$, na geometria de placas paralelas de $25 \mathrm{~mm}$, com o gap de $1 \mathrm{~mm}$ entre as placas. O ensaio é feito a tensão controlada de acordo com a norma ASTM D7405 (2010), onde a amostra é submetida a uma carga constante durante 1s e, sem seguida, a carga é retirada, permitindo que a amostra permaneça em repouso durante 9s. Dez ciclos de fluência e recuperação são rodados em cinco temperaturas de ensaio $\left(52,58,64,70\right.$ e $\left.76^{\circ} \mathrm{C}\right)$, a uma tensão de $0,1 \mathrm{kPa}$, seguido por dez ciclos em cada temperatura, a uma tensão de $3.200 \mathrm{kPa}$. Os tempos de carregamento e repouso e o número de ciclos em cada nível de tensão são mantidos. Neste ensaio são monitorados os parâmetros: (i) percentual de recuperação (\%R), utilizado para fornecer uma indicação da resposta elástica retardada do ligante asfáltico; (ii) compliância não-recuperável $\left(\mathrm{J}_{\mathrm{nr}}\right)$, utilizado para avaliar o potencial do ligante asfáltico a

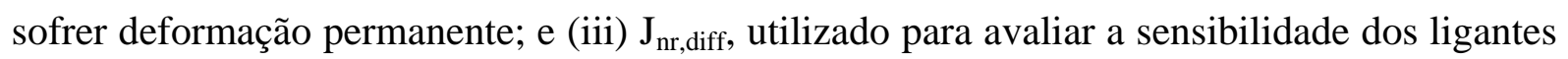
asfálticos a mudanças no nível de tensão.

\subsubsection{Linear Amplitude Sweep (LAS)}

O ensaio é realizado utilizando o Reômetro de Cisalhamento Dinâmico Physica MCR 301 - Anton Paar $^{\circledR}$, na geometria de placas paralelas de $8 \mathrm{~mm}$, com o gap de $2 \mathrm{~mm}$ entre as placas. Este ensaio é dividido em duas etapas: (i) uma varredura de frequência de $0,1-30 \mathrm{~Hz}$, a uma amplitude de deformação de $0,1 \%$ e (ii) uma varredura de amplitude de deformação a uma amplitude de 0,1 - 30\% de deformação, a uma frequência fixa de $10 \mathrm{~Hz}$. Os ensaios foram realizados a uma temperatura de 25 e $35^{\circ} \mathrm{C}$. Neste ensaio o comprimento da trinca $\left(\mathrm{a}_{\mathrm{f}}\right)$ na ruptura por fadiga é monitorado. 


\section{CAPÍTUlo 4. CARACTERIZAÇÃo QUímicA, GRAU DE DESEMPENHO, RIGIDEZ E ELASTICIDADE DOS LIGANTES ASFÁLTICOS}

Neste capítulo estão apresentados os resultados dos ensaios de caracterização química dos ligantes asfálticos puros e modificados, na condição virgem, do grau de desempenho dos ligantes asfálticos puros e modificados, na condição virgem, e os resultados da caracterização reológica dos ligantes asfálticos puros e modificados nas três condições de envelhecimento (virgem, envelhecido a curto prazo e envelhecido a longo prazo). São apresentadas as análises destes resultados e a comparação entre os ligantes asfálticos, destacando a influência da composição química no efeito causado pela adição de ácido polifosfórico.

\subsection{ANÁLISE DE RESULTADOS}

\subsubsection{Cromatografia de camada fina com detecção por ionização de chama}

O efeito da adição do PPA sobre a composição química dos ligantes asfálticos puros foi estudado por TLC-FID (Thin-layer chromatography with flame ionization detection). A partir dos valores médios das quatro frações do ligante asfáltico (saturados, aromáticos, resinas e asfaltenos), o índice de instabilidade coloidal $\left(\mathrm{I}_{\mathrm{c}}\right)$ das amostras foi calculado e utilizado como critério para caracterização do ligante asfáltico em tipo SOL (viscoso e menos estruturado) ou em tipo GEL (elástico e mais estruturado) (GAESTEL et al., 1971 e LESUEUR, 2009). A Tabela 4.1 mostra as frações SARA dos ligantes asfálticos puro e modificados, na condição virgem, e a Tabela 4.2 mostra os valores de $I_{c}$ destes ligantes asfálticos.

Os ligantes asfálticos do tipo GEL são mais resistentes à aplicação de cargas, consequentemente, são menos propensos ao trincamento e apresentam baixa elasticidade. Já os ligantes asfálticos do tipo SOL apresentam maior suscetibilidade térmica por terem óleos intermicelares aromáticos, o que os torna mais moles, e apresentam alta elasticidade (LESUEUR, 2009). Segundo Huang et al. (2011), os ligantes asfálticos do tipo GEL são mais susceptíveis ao envelhecimento termo-oxidativo, enquanto os ligantes asfálticos do tipo SOL não são tão susceptíveis ao envelhecimento. 
Tabela 4.1 - Composição química dos ligantes asfálticos puros e modificados com PPA

\begin{tabular}{ccccc}
\hline Amostra & $\begin{array}{c}\text { Saturados } \\
(\boldsymbol{\%})\end{array}$ & $\begin{array}{c}\text { Aromáticos } \\
(\boldsymbol{\%})\end{array}$ & $\begin{array}{c}\text { Resinas } \\
(\boldsymbol{\%})\end{array}$ & $\begin{array}{c}\text { Asfaltenos } \\
(\boldsymbol{\%})\end{array}$ \\
\hline LUBNOR & 15,57 & 31,78 & 26,29 & 26,37 \\
LUBNOR + 0,5\% PPA & 16,94 & 38,45 & 18,19 & 26,43 \\
LUBNOR + 1,0\% PPA & 19,27 & 37,82 & 20,00 & 22,91 \\
LUBNOR + 1,5\% PPA & 17,54 & 41,43 & 20,59 & 20,44 \\
LUBNOR + 2,0\% PPA & 15,56 & 41,27 & 20,96 & 22,21 \\
REDUC & 10,27 & 38,41 & 33,42 & 17,94 \\
REDUC + 0,5\% PPA & 3,23 & 60,44 & 23,08 & 13,25 \\
REDUC + 1,0\% PPA & 8,83 & 43,75 & 29,87 & 17,54 \\
REDUC + 1,5\% PPA & 15,79 & 41,57 & 26,48 & 16,168 \\
REDUC + 2,0\% PPA & 12,80 & 39,17 & 30,10 & 17,94 \\
\hline
\end{tabular}

Tabela 4.2 - Índice de instabilidade coloidal dos ligantes asfálticos puros e modificados com PPA

\begin{tabular}{cc}
\hline amostra & $\mathbf{I}_{\mathbf{c}}$ \\
\hline LUBNOR & 0,72 \\
LUBNOR + 0,5\% PPA & 0,77 \\
LUBNOR + 1,0\% PPA & 0,73 \\
LUBNOR + 1,5\% PPA & 0,61 \\
LUBNOR + 2,0\% PPA & 0,61 \\
REDUC & 0,38 \\
REDUC + 0,5\% PPA & 0,20 \\
REDUC + 1,0\% PPA & 0,36 \\
REDUC + 1,5\% PPA & 0,47 \\
REDUC + 2,0\% PPA & 0,44 \\
\hline
\end{tabular}

Os resultados da adição sucessiva de PPA ao ligante asfáltico da REDUC mostram uma tendência do ligante asfáltico adquirir um comportamento cada vez mais característico do tipo SOL (menos estruturado). De modo diverso, a tendência do ligante asfáltico da LUBNOR com a adição de PPA é tornar-se cada vez mais estruturado (tipo GEL). Dois 
mecanismos decorrentes da adição de PPA parecem ser predominantes em cada caso: (1) um mecanismo que induz a agregação dos asfaltenos, que pode ocorrer por meio de uma associação intermolecular, ou (2) um mecanismo que levaria a uma dispersão dos asfaltenos. Assim sendo, os dados apresentados sugerem que o ligante asfáltico da REDUC quando modificado com PPA formaria, predominantemente, associações intermoleculares, enquanto que a dispersão dos asfaltenos seria preferencial no caso da adição de PPA ao ligante asfáltico da LUBNOR. As características diversas apresentadas pelos dois ligantes são devidas às proporções relativas das frações SARA - particularmente, dos teores de asfaltenos e de resinas em cada caso.

De um modo bastante simplificado, é possível dizer que os ligantes asfálticos quando modificados podem tornar-se mais "rígidos" ou mais "moles". O aumento de "rigidez" $($ REDUC + PPA) poderia ser explicado pela formação de pontes de nitrogênio $(\mathrm{N}-\mathrm{N})$, que provoca aumento da massa molar e elevação da transição vítrea (redução da mobilidade) do ligante asfáltico. Um mecanismo provável para explicar a tendência do LUBNOR + PPA ao comportamento cada vez mais estruturado (tipo GEL) seria a redução das ligações de hidrogênio $(\mathrm{H}-\mathrm{H})$ com a possibilidade de fosforilação. Neste caso, ocorreria uma redução da massa molar e uma redução da transição vítrea do ligante asfáltico.

Observa-se que o ligante asfáltico proveniente da LUBNOR apresenta um comportamento de um ligante asfáltico bem estruturado do tipo GEL ( $\mathrm{I}_{\mathrm{c}}$ superior a 0,5$)$. Já o ligante asfáltico da REDUC apresenta um comportamento do tipo SOL-GEL ( $\mathrm{I}_{\mathrm{c}}$ entre 0,1 e 0,5), ou seja, o ligante asfáltico da REDUC apresenta um comportamento intermediário entre o tipo SOL e GEL. O REDUC apresenta um maior potencial a sofrer deformação permanente e é menos sensível ao envelhecimento. Esses resultados foram confirmados por meio dos resultados de compliância não-recuperável, que se mostraram maiores para o REDUC que para o LUBNOR, e pela variação na rigidez $\left(\mathrm{G}^{*}\right)$ em função do envelhecimento, que foi menor para o REDUC que para o LUBNOR.

\subsubsection{Grau de Desempenho}

Como indicado na literatura, proporções de ácido de 1,0 até 1,5\% são suficientes para alterar em um ou dois níveis o grau de desempenho do ligante asfáltico em temperaturas altas. 
Neste sentido, a Figura 4.1 apresenta uma comparação entre o grau de desempenho contínuo (continuous grade) dos ligantes asfálticos modificados com 1,5\% de PPA e o grau de desempenho contínuo dos ligantes asfálticos de base. O grau de desempenho das amostras foi obtido com base nos valores do parâmetro $\mathrm{G}^{*} / \operatorname{sen} \delta$ das amostras virgens, de acordo com o novo critério da especificação Superpave. A adição de 1,5\% de PPA é suficiente para elevar o PG do CAP LUBNOR de 70 para 88 (3 níveis), enquanto o PG do CAP REDUC aumentou de 64 para 70 (apenas 1 nível). Estes resultados reforçam o fato de quão dependente é o efeito da adição de PPA da composição química do ligante asfáltico de base. O CAP REDUC se mostrou o menos efetivo à adição de PPA para a proporção de $1,5 \%$. O CAP LUBNOR atingiu um valor mais alto de PG, pois parte de um PG mais elevado que o REDUC.

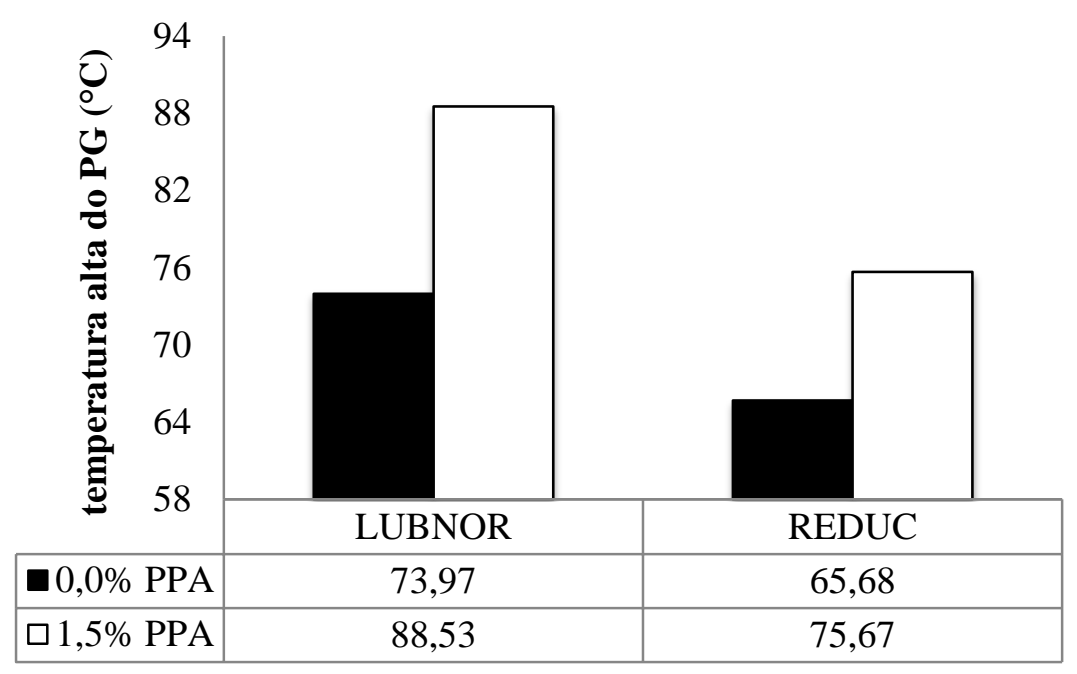

Figura 4.1 - Grau contínuo dos ligantes asfálticos puros e modificados com 1,5\% de PPA

A Figura 4.2 apresenta o grau contínuo dos ligantes asfálticos em função da proporção de PPA. É evidente que alguns ligantes asfálticos requerem uma maior proporção de ácido em relação a outros para elevar o grau de desempenho em um, dois ou três níveis. O ligante asfáltico da REDUC apresentou um grau de desempenho equivalente para baixas proporções de PPA (0,5\%, por exemplo). No entanto, o ligante asfáltico proveniente da LUBNOR apresentou um aumento mais expressivo no grau de desempenho à medida que a proporção de PPA aumentou.

A quantidade de PPA necessária para elevar a temperatura alta do PG de cada ligante asfáltico de base em um, dois ou três níveis está mostrada na Tabela 4.3. Para elevar a temperatura alta do PG em um nível, é necessário adicionar $0,35 \%$ de PPA no CAP da 
LUBNOR (PG 70 para 76) e 0,30\% de PPA no CAP da REDUC (PG 64 para 70). Para elevar a temperatura alta do PG em dois níveis é necessário adicionar 1,05 e 1,55 de PPA nos ligantes asfálticos da LUBNOR (PG 70 para 82) e da REDUC (PG 64 para 76), respectivamente. Para elevar a temperatura alta do PG em três níveis, as proporções de PPA necessárias seriam de 1,45 e 2,00 para os ligantes asfálticos da LUBNOR (PG 70 para 88) e da REDUC (PG 64 para 82), respectivamente. O CAP da LUBNOR se mostrou o mais sensível à adição de PPA, aumentando a temperatura alta do PG com o menor teor de PPA necessário.

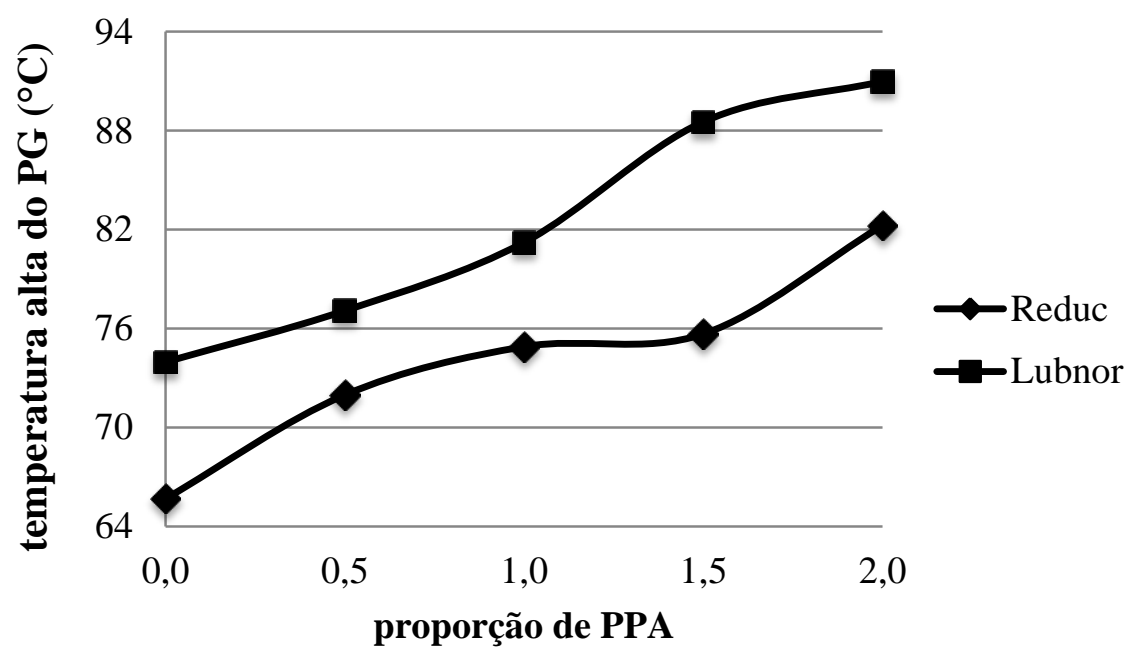

Figura 4.2 - Grau contínuo dos ligantes asfálticos em função da proporção de PPA

Tabela 4.3 - Quantidade de PPA necessária para aumentar o PG nas temperaturas altas

\begin{tabular}{ccccc}
\hline Ligante Asfáltico & PG 70 & PG 76 & PG 82 & PG 88 \\
\hline LUBNOR & 0,00 & 0,35 & 1,05 & 1,45 \\
REDUC & 0,30 & 1,55 & 2,00 & - \\
\hline
\end{tabular}

É importante lembrar que o grau de desempenho dos ligantes asfálticos é apenas um critério de classificação baseado no nível de rigidez das amostras nas temperaturas de ocorrência de deformação permanente. Esse critério serve para indicar que os ligantes asfálticos modificados são mais rígidos do que seus ligantes asfálticos de base, mas não pode ser utilizado para classificar ou ordenar diferentes ligantes asfálticos em termos de resistência à deformação permanente. Para isto, o ensaio MSCR deve ser realizado a fim de verificar a 
real contribuição que o PPA confere aos ligantes asfálticos modificados, em termos de recuperação elástica e deformação não-recuperável.

\subsubsection{Viscosidade}

As Figuras 4.3 e 4.4 apresentam o comportamento da viscosidade rotacional em função de temperatura do LUBNOR e do REDUC, respectivamente, a 135, 144, 150, 163 e $177^{\circ} \mathrm{C}$. A Tabela 4.4 apresenta os valores das viscosidades rotacional do LUBNOR e do REDUC a $135,144,150,163$ e $177^{\circ} \mathrm{C}$. Como encontrado na literatura, a adição de PPA aumenta a viscosidade do ligante asfáltico. Como o LUBNOR é mais viscoso que o REDUC, a viscosidade das amostras preparadas com o LUBNOR e PPA são mais viscosas que as respectivas preparadas com o REDUC e PPA, em todas as temperaturas.

\section{LUBNOR}

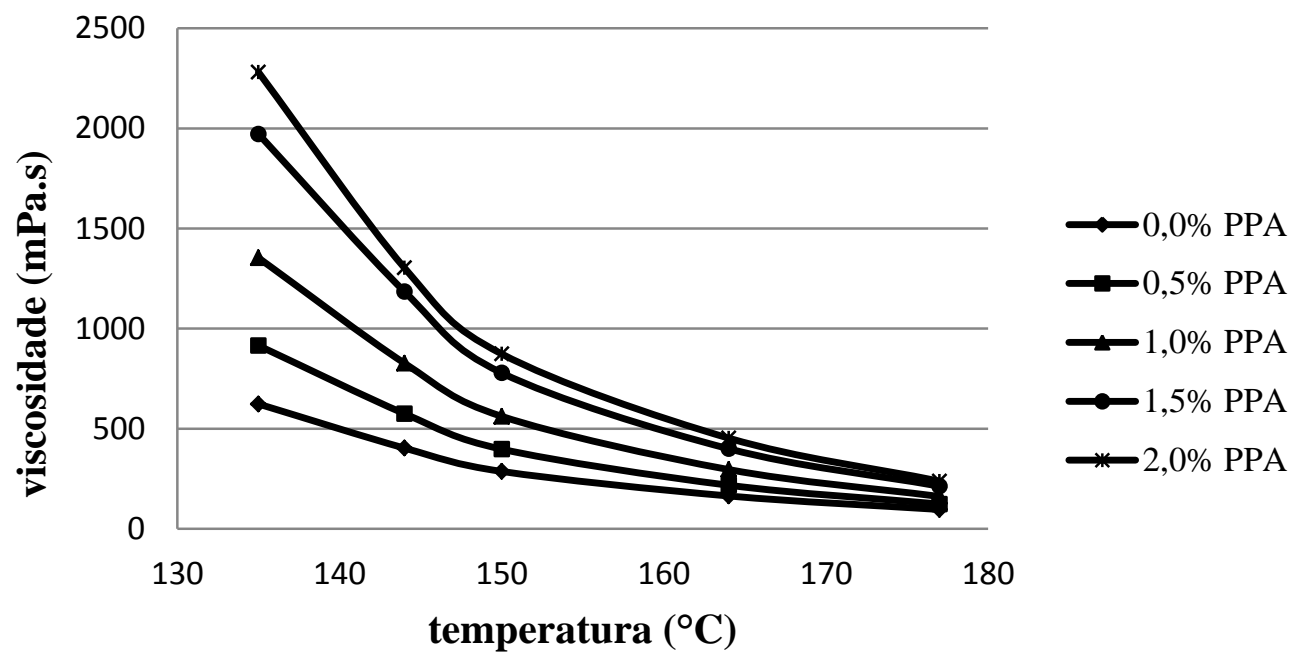

Figura 4.3 - Viscosidade rotacional do LUBNOR puro e modificados com PPA

De uma forma geral, o LUBNOR é mais sensível a adição de PPA do que o REDUC. O REDUC é mais sensível apenas para a adição de teores muito elevados de PPA (2,0\%). O efeito da adição de PPA é mais expressivo nas temperaturas mais baixas para os dois ligantes asfálticos. Tendo em vista como referência a limitação imposta pela especificação Superpave, que limita a viscosidade ao máximo de $3 \mathrm{~Pa} . \mathrm{s}$ a $135^{\circ} \mathrm{C}$, nenhum dos ligantes asfálticos modificados ultrapassou este limite. Logo, o aumento da viscosidade rotacional provocado 
pela adição de PPA não se mostrou grande o suficiente a pronto de prejudicar atividades como o bombeamento do material modificado.

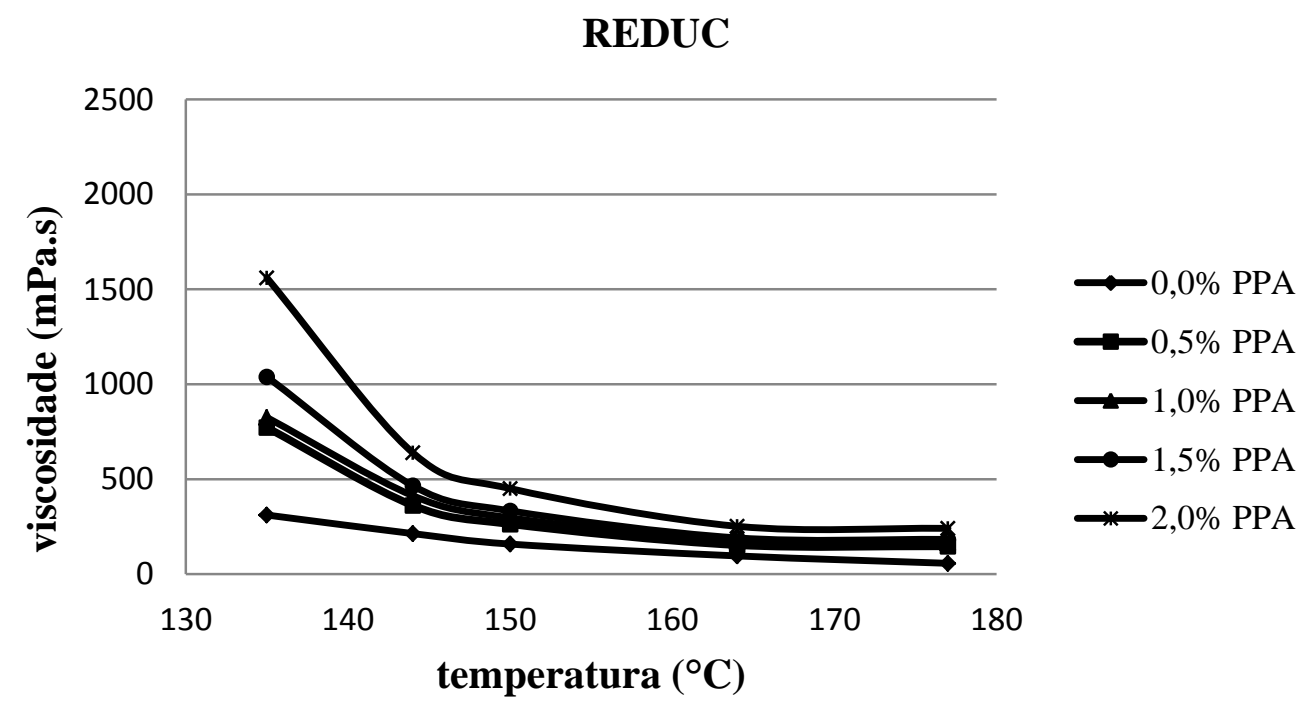

Figura 4.4 Viscosidade rotacional do REDUC puro e modificados com PPA

Tabela 4.4 - Viscosidades do LUBNOR e do REDUC puro e modificados em função de temperatura

\begin{tabular}{cccccc}
\hline \multirow{2}{*}{ Amostra } & \multicolumn{5}{c}{ Viscosidade (mPa.s) } \\
& $\mathbf{1 3 5}^{\mathbf{}} \mathbf{C}$ & $\mathbf{1 4 4}^{\mathbf{}} \mathbf{C}$ & $\mathbf{1 5 0}^{\mathbf{}} \mathbf{C}$ & $\mathbf{1 6 4}^{\mathbf{}} \mathbf{C}$ & $\mathbf{1 7 7}^{\mathbf{}} \mathbf{C}$ \\
\hline LUBNOR & 624 & 404 & 287 & 164 & 97 \\
LUBNOR + 0,5\% PPA & 915 & 576 & 398 & 218 & 124 \\
LUBNOR + 1,0\% PPA & 1353 & 828 & 562 & 296 & 162 \\
LUBNOR + 1,5\% PPA & 1972 & 1186 & 779 & 400 & 213 \\
LUBNOR + 2,0\% PPA & 2280 & 1304 & 874 & 453 & 238 \\
REDUC & 311 & 214 & 158 & 96 & 57 \\
REDUC + 0,5\% PPA & 772 & 362 & 264 & 153 & 147 \\
REDUC + 1,0\% PPA & 825 & 413 & 297 & 171 & 164 \\
REDUC + 1,5\% PPA & 1039 & 466 & 333 & 191 & 183 \\
REDUC + 2,0\% PPA & 1560 & 639 & 451 & 252 & 241 \\
\hline
\end{tabular}

\subsubsection{Temperatura de usinagem e compactação}

As temperaturas de usinagem e compactação dos ligantes asfálticos foram obtidas a partir dos resultados de viscosidade rotacional. Os cálculos das temperaturas de compactação 
e usinagem dos ligantes asfálticos virgens foram realizados com base nos limites tradicionais de viscosidade rotacional: $0,17 \pm 0,02 \mathrm{~Pa}$.s para a temperatura de usinagem e 0,28 $\pm 0,03$ Pa.s para a temperatura de compactação. Estas temperaturas são estimadas com base em intervalos de viscosidades, a fim de normalizar o efeito da rigidez do ligante asfáltico nas propriedades volumétricas da mistura asfáltica.

A Tabela 4.5 apresenta as temperaturas de usinagem de e compactação dos ligantes asfálticos puros e modificados. As temperaturas de usinagem e de compactação do LUBNOR modificado com altos teores de PPA são muito elevadas, o que prejudica a trabalhabilidade do ligante asfáltico, além do alto consumo de energia necessário para atingir as temperaturas de usinagem e de compactação e a liberação de voláteis prejudiciais à saúde, podendo inviabilizar a utilização deste ligante asfáltico.

Tabela 4.5 - Temperatura de usinagem e compactação dos ligantes asfálticos puros e modificados

\begin{tabular}{ccc}
\hline Ligante asfáltico & $\begin{array}{c}\text { Temperatura de usinagem } \\
\left({ }^{\circ} \mathbf{C}\right)\end{array}$ & $\begin{array}{c}\text { Temperatura de } \\
\text { compactação }\left({ }^{\circ} \mathbf{C}\right)\end{array}$ \\
\hline LUBNOR + 0,0\% PPA & $160-166$ & $148-153$ \\
LUBNOR + 0,5\% PPA & $167-172$ & $155-161$ \\
LUBNOR + 1,0\% PPA & $175-180$ & $162-167$ \\
LUBNOR + 1,5\% PPA & $180-185$ & $169-174$ \\
LUBNOR + 2,0\% PPA & $183-188$ & $172-178$ \\
REDUC + 0,0\% PPA & $147-151$ & $146-140$ \\
REDUC + 0,5\% PPA & $158-165$ & $149-155$ \\
REDUC + 1,0\% PPA & $162-168$ & $152-157$ \\
REDUC + 1,5\% PPA & $165-170$ & $159-164$ \\
REDUC + 2,0\% PPA & $172-178$ & \\
\hline
\end{tabular}


Observa-se que a adição de PPA aumenta a temperatura de usinagem e de compactação dos ligantes asfálticos, uma vez que a viscosidade dos ligantes asfálticos tornase maior com a adição de PPA. As temperaturas de usinagem e compactação dos ligantes asfálticos da LUBNOR modificados com PPA são mais elevadas do que as temperaturas de usinagem e compactação dos ligantes asfálticos da REDUC modificados com PPA uma vez que o LUBNOR apresenta uma viscosidade mais elevada que o REDUC.

Além disso, a diferença entre as temperaturas de usinagem e de compactação do LUBNOR + 1,5\% PPA e do LUBNOR + 2,0\% PPA é muito pequena, logo a adição de teores de PPA maiores que $1,5 \%$ ao LUBNOR não é recomendada.

\subsubsection{Curva-mestre}

A caracterização completa de um ligante asfáltico deveria compreender ensaios reológicos ao longo de toda a faixa de temperaturas ou de tempos de carregamento à qual o pavimento estaria submetido ao longo da sua vida de serviço. As curvas-mestre são uma representação do comportamento reológico do material, em função da frequência (ou do tempo) de carregamento, empregando uma função reológica qualquer, para uma única temperatura, denominada temperatura de referência, em um espectro de frequências ou tempos de carregamento. $\mathrm{O}$ tempo e a temperatura têm efeitos que podem ser intercambiados, ou seja, um determinado aumento na temperatura é equivalente a uma determinada redução na frequência de carregamento. A separação dos efeitos do tempo e da temperatura caracteriza materiais cujo comportamento é denominado termorreologicamente simples. Ao analisar uma curva-mestre, o efeito da frequência alta é equivalente ao da temperatura baixa e o efeito da frequência baixa é equivalente ao da temperatura alta.

As Figuras 4.5, 4.6 e 4.7 apresentam o efeito da adição de diferentes teores de PPA no ligante asfáltico da LUBNOR, não-envelhecido, envelhecido no RTFOT e envelhecido no PAV respectivamente. Observa-se que os ligantes asfálticos apresentaram um comportamento reológico típico, caracterizado pelo aumento de rigidez com o aumento da frequência de carregamento, destacando o enrijecimento dos materiais com a redução do tempo de aplicação de carga ou da temperatura. O aumento de $\mathrm{G}^{*}$ é proporcional ao aumento do teor de PPA. A adição de PPA provoca um enrijecimento dos ligantes asfálticos mais expressivo na região de baixas frequências (temperatura alta). $\mathrm{O}$ aumento de $\mathrm{G}^{*}$ do ligante asfáltico é desejável, pois contribui com o aumento da resistência à deformação permanente das misturas asfálticas. Na região de altas frequências, os ligantes asfálticos puro e modificados tendem a um patamar de 
rigidez, onde o ligante asfáltico teria um comportamento vítreo, não sendo observado efeito significativo da adição de PPA. Isto se reflete em um efeito inexpressivo sobre a resistência ao trincamento térmico, ou seja, a adição de PPA não contribui nem prejudica a resistência ao trincamento térmico.

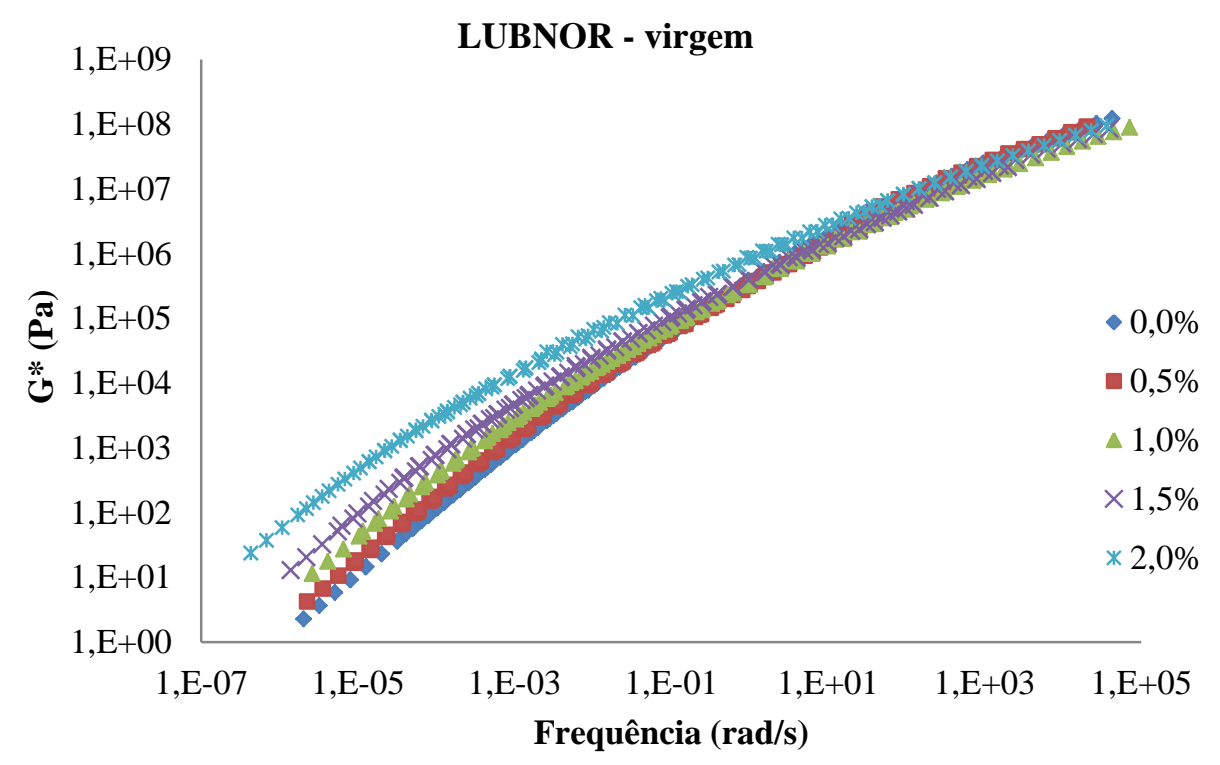

Figura 4.5 - Variação de $\mathrm{G}^{*}$ em função da frequência para LUBNOR não-envelhecidos, modificados com cinco teores de PPA

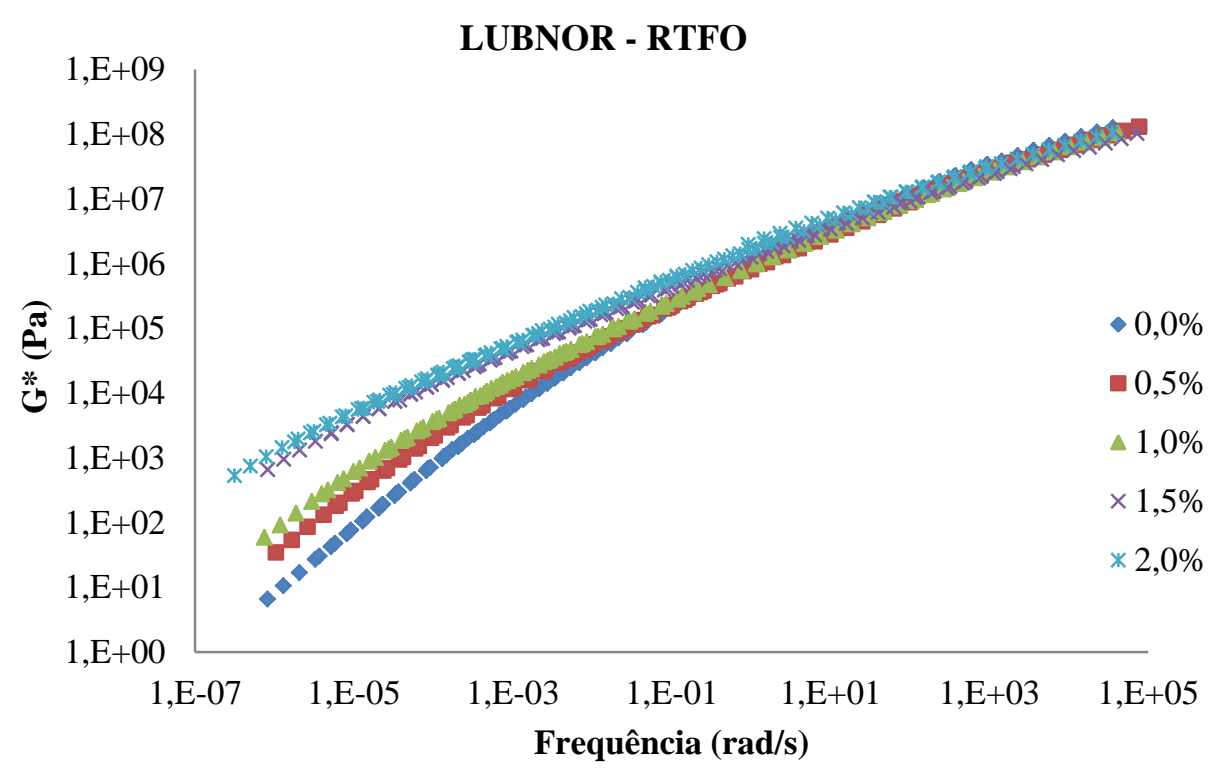

Figura 4.6 - Variação de $G^{*}$ em função da frequência para LUBNOR envelhecidos no RTFOT, modificados com cinco teores de PPA 


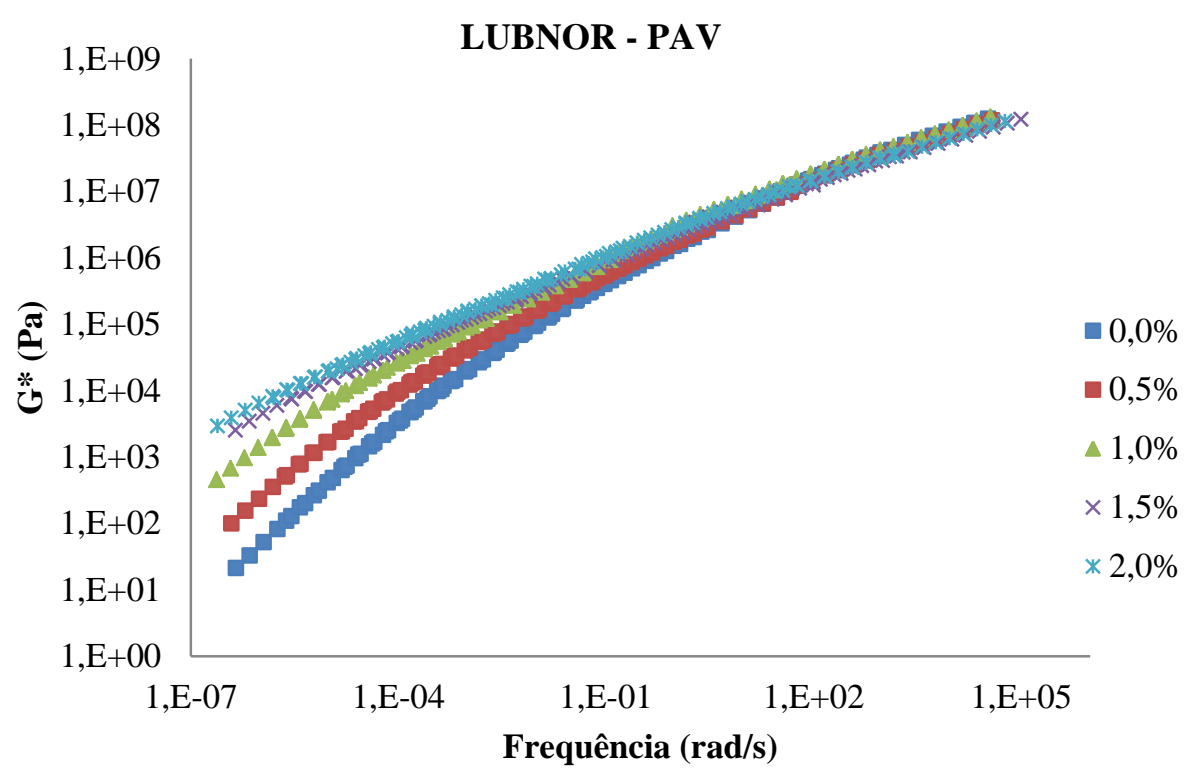

Figura 4.7 - Variação de G* em função da frequência para LUBNOR envelhecidos no PAV, modificados com cinco teores de PPA

As Figuras de 4.8 a 4.12 apresentam a variação da rigidez dos ligantes asfálticos da LUBNOR puro e modificados em função da frequência para os ligantes asfálticos virgens e envelhecidos a curto e longo prazo.

A variação relativa dos valores de $G^{*}$, provocada pelos envelhecimentos a curto e a longo prazos, é gradativamente decrescente com o aumento da frequência de carregamento, indicando que o efeito enrijecedor devido aos envelhecimentos não se mantém ao longo de todo o espectro de frequência de carregamento (ou de temperatura). Nas frequências altas (temperaturas baixas), o efeito do envelhecimento sobre a rigidez é inexpressivo para todos os ligantes asfálticos, o que se reflete em um também inexpressivo efeito sobre a resistência ao trincamento de origem térmica.

$\mathrm{Na}$ maioria dos casos, tal efeito enrijecedor é mais facilmente percebido nas frequências baixas (temperaturas altas), em que se vê, de uma forma geral, um aumento um pouco mais expressivo de $\mathrm{G}^{*}$ das amostras envelhecidas a curto prazo e um aumento menos expressivo de $\mathrm{G}^{*}$ das amostras envelhecidas no PAV. Nas temperaturas altas, o efeito enrijecedor do envelhecimento se soma ao efeito enrijecedor do PPA, favorecendo o aumento da resistência à deformação permanente das misturas asfálticas. 


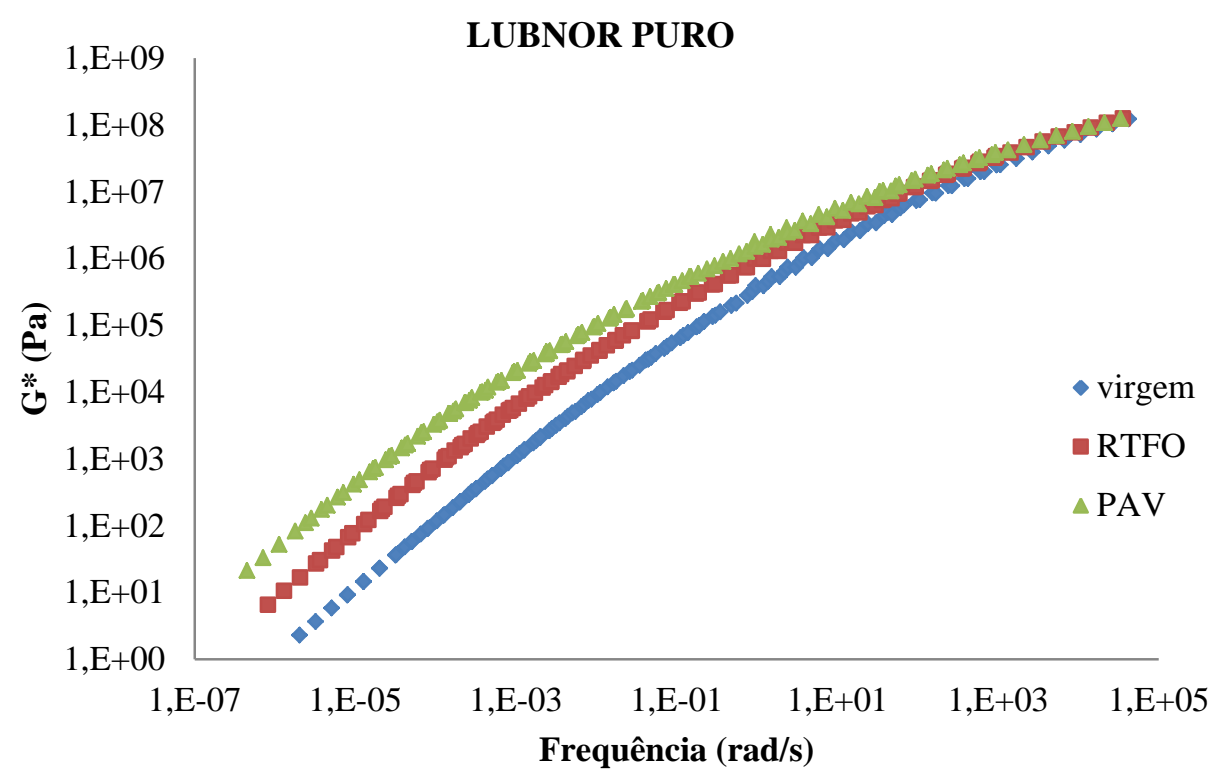

Figura 4.8 - Variação de $G^{*}$ em função da frequência para LUBNOR não-envelhecido e envelhecido no RTFOT e PAV

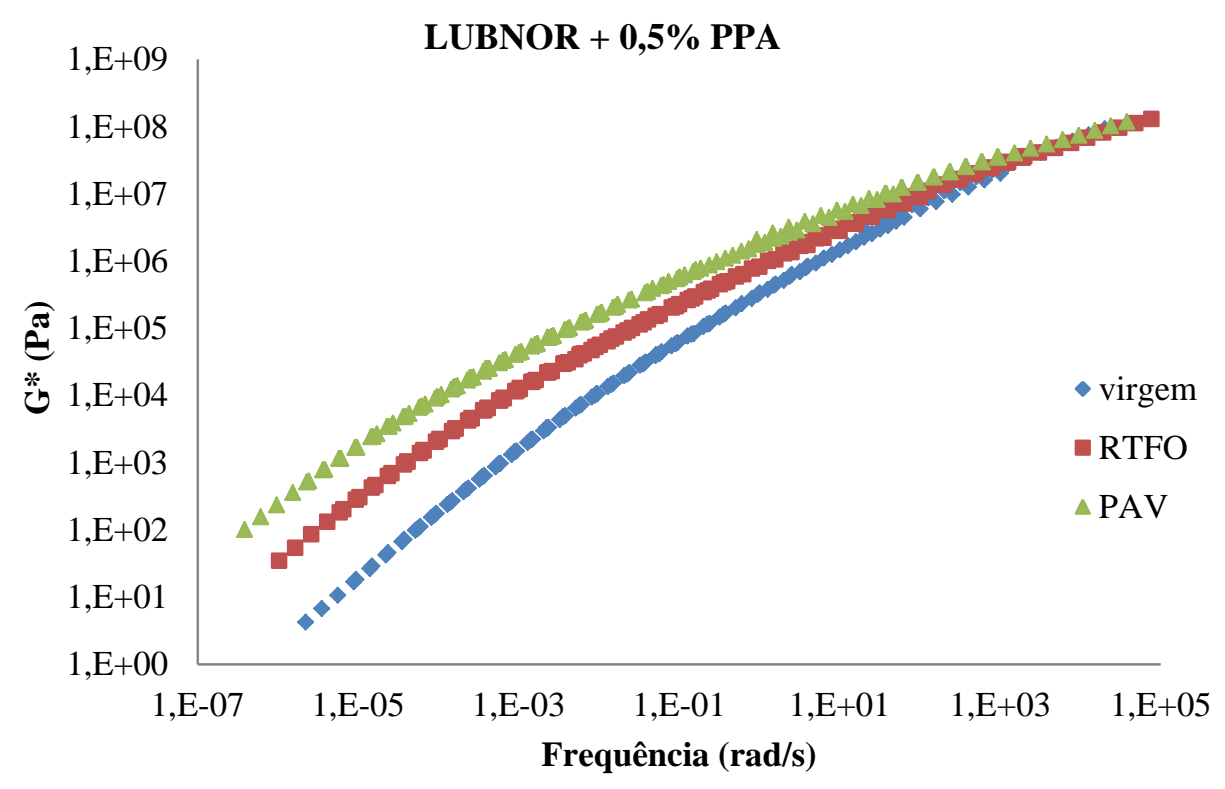

Figura 4.9 - Variação de $\mathrm{G}^{*}$ em função da frequência para LUBNOR, modificados com $0.5 \%$ de PPA, nãoenvelhecido e envelhecidos no RTFOT e PAV

As Figuras 4.13, 4.14 e 4.15 apresentam o efeito na rigidez da adição de diferentes teores de PPA no ligante asfáltico da REDUC, não-envelhecido, envelhecidos a curto e a longo prazo, respectivamente. Assim como foi observado para o ligante asfáltico da 
LUBNOR, os ligantes asfálticos da REDUC apresentaram um comportamento reológico típico. O enrijecimento provocado pela adição de PPA foi mais expressivo nas frequências mais baixas (altas temperaturas), tal enrijecimento é desejável, uma vez que contribui com o aumento da resistência à deformação permanente das misturas asfálticas.

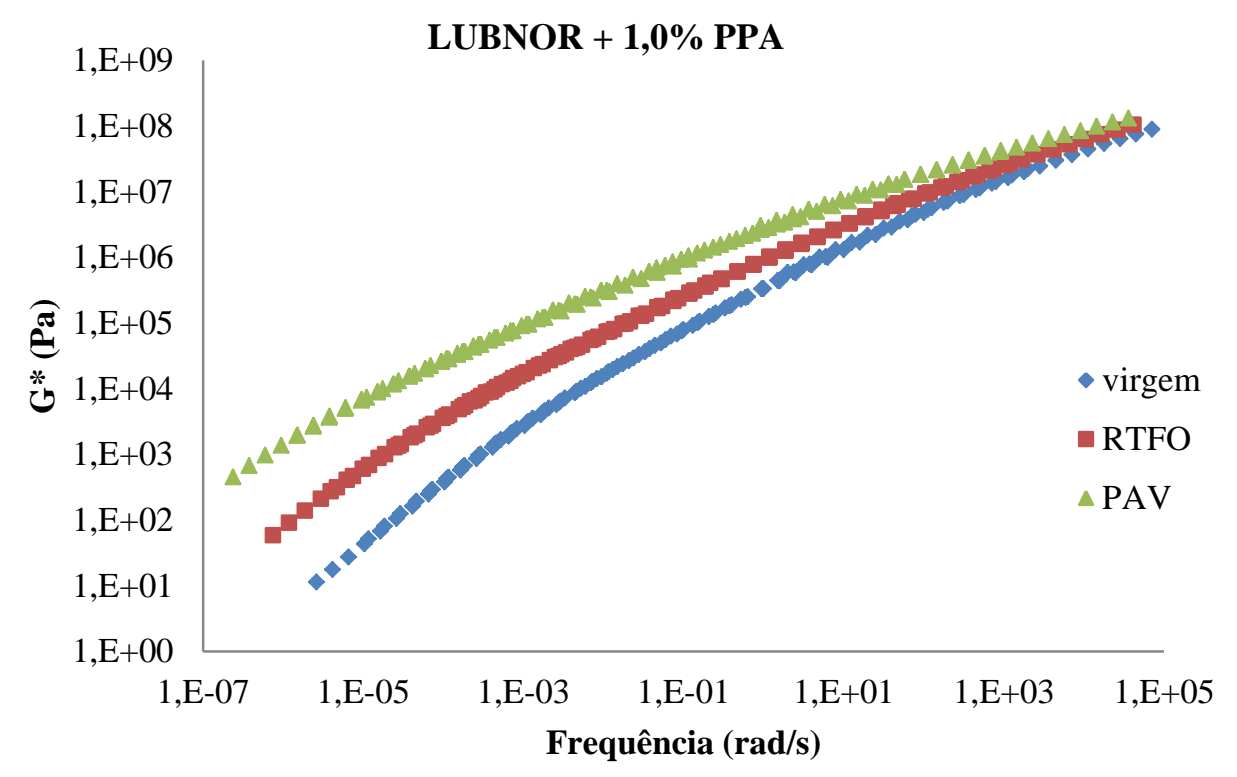

Figura 4.10 - Variação de G* em função da frequência para LUBNOR, modificados com 1,0\% de PPA, nãoenvelhecido e envelhecidos no RTFOT e PAV

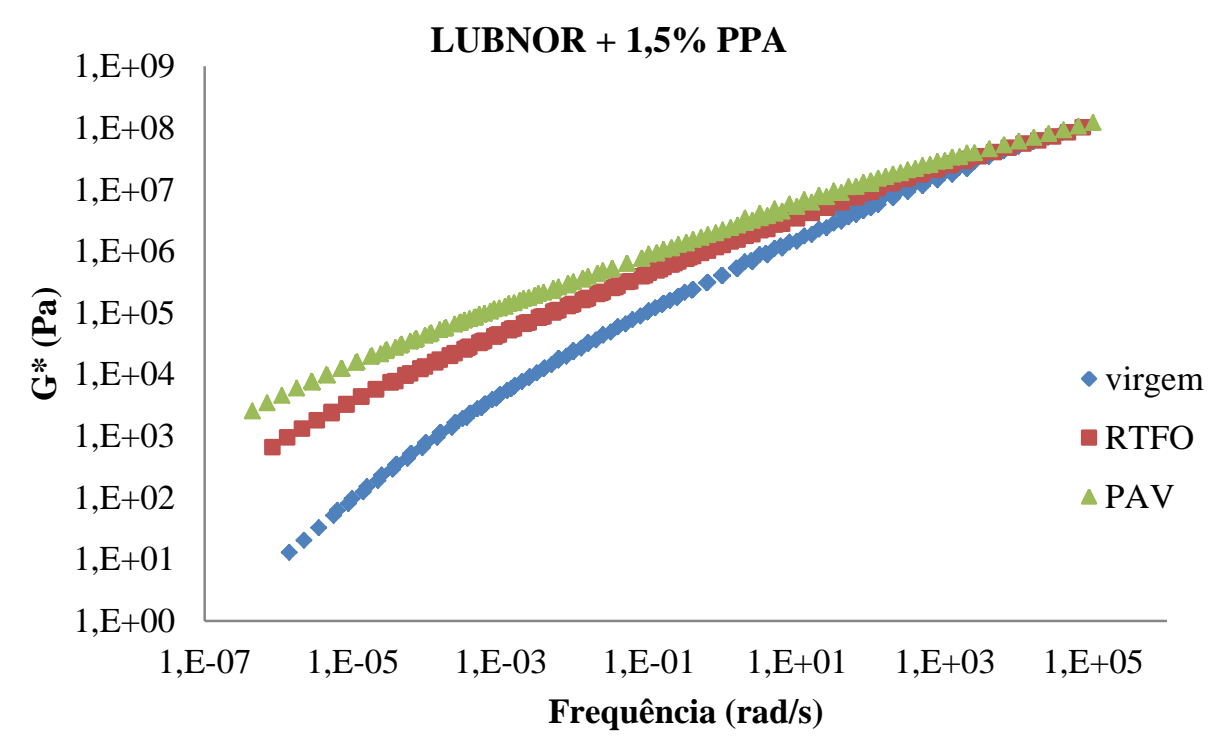

Figura 4.11 - Variação de $\mathrm{G}^{*}$ em função da frequência para LUBNOR, modificados com 1.5\% de PPA, nãoenvelhecido e envelhecidos no RTFOT e PAV 
Nas frequências mais altas, o efeito da adição de PPA foi inexpressivo uma vez que todos os ligantes asfálticos tendem a um valor máximo de rigidez. Isto se reflete em um efeito inexpressivo sobre a resistência ao trincamento térmico, ou seja, a adição de PPA não contribui nem prejudica a resistência ao trincamento térmico.

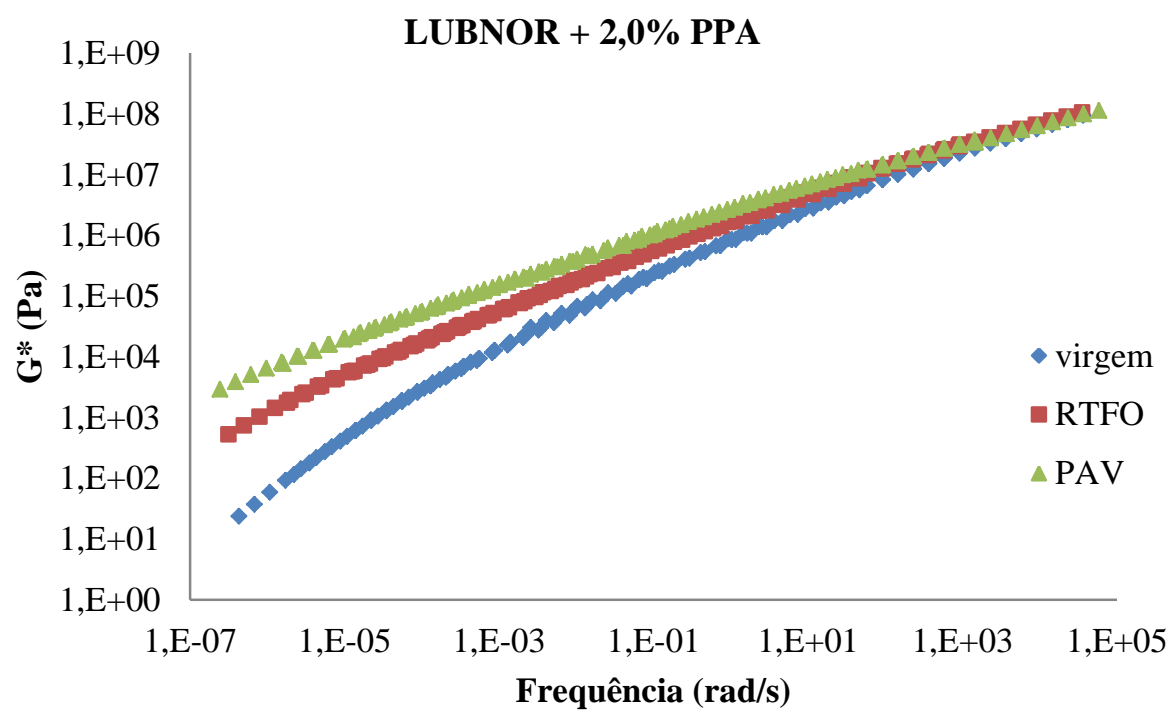

Figura 4.12 - Variação de G* em função da frequência para LUBNOR, modificados com 2,0\% de PPA, nãoenvelhecido e envelhecidos no RTFOT e PAV

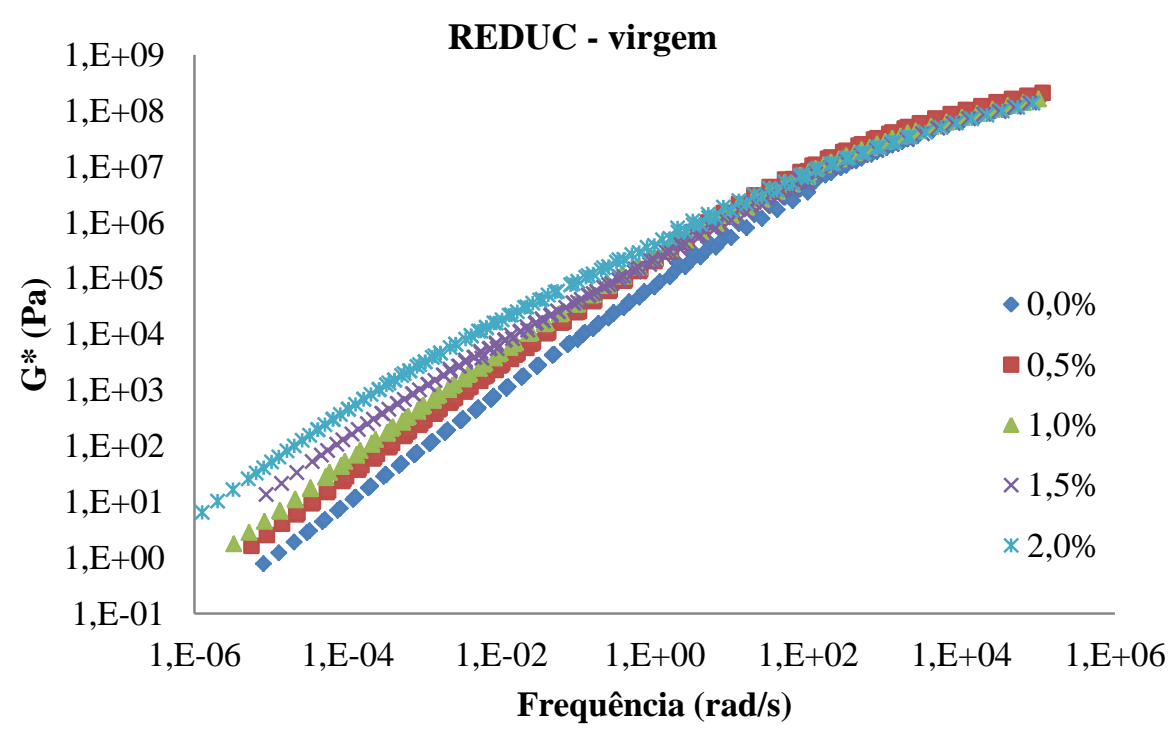

Figura 4.13 - Variação de $G^{*}$ em função da frequência para REDUC não-envelhecidos, modificados com cinco teores de PPA 
As Figuras de 4.16 a 4.20 apresentam a variação da rigidez dos ligantes asfálticos em função da frequência para os ligantes asfálticos da REDUC, puro e modificados, virgens e envelhecidos a curto e longo prazo. A variação relativa dos valores de $\mathrm{G}^{*}$, provocada pelos envelhecimentos no RTFOT e no PAV indicam que o efeito erijecedor do PPA não se mantém para todo o espectro de frequência de carregamento (ou temperatura). Assim como foi observado para o ligante asfáltico da LUBNOR, o efeito enrijecedor do PPA é mais expressivo nas frequências baixas (temperaturas altas).

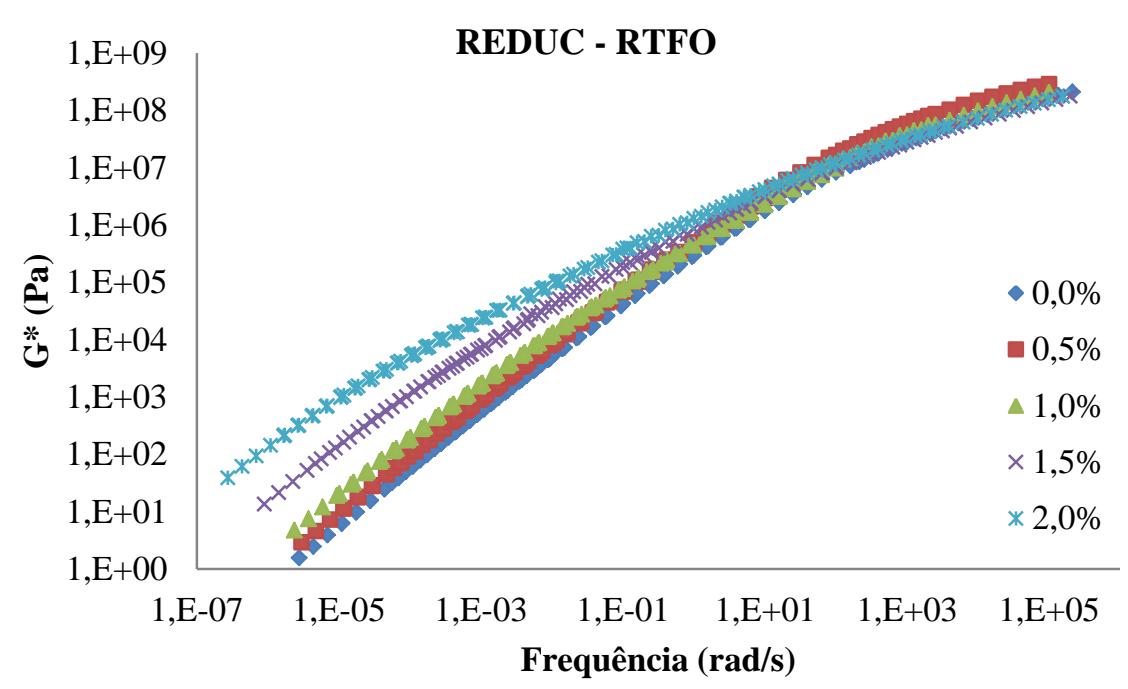

Figura 4.14 - Variação de $\mathrm{G}^{*}$ em função da frequência para REDUC envelhecidos no RTFOT, modificados com cinco teores de PPA

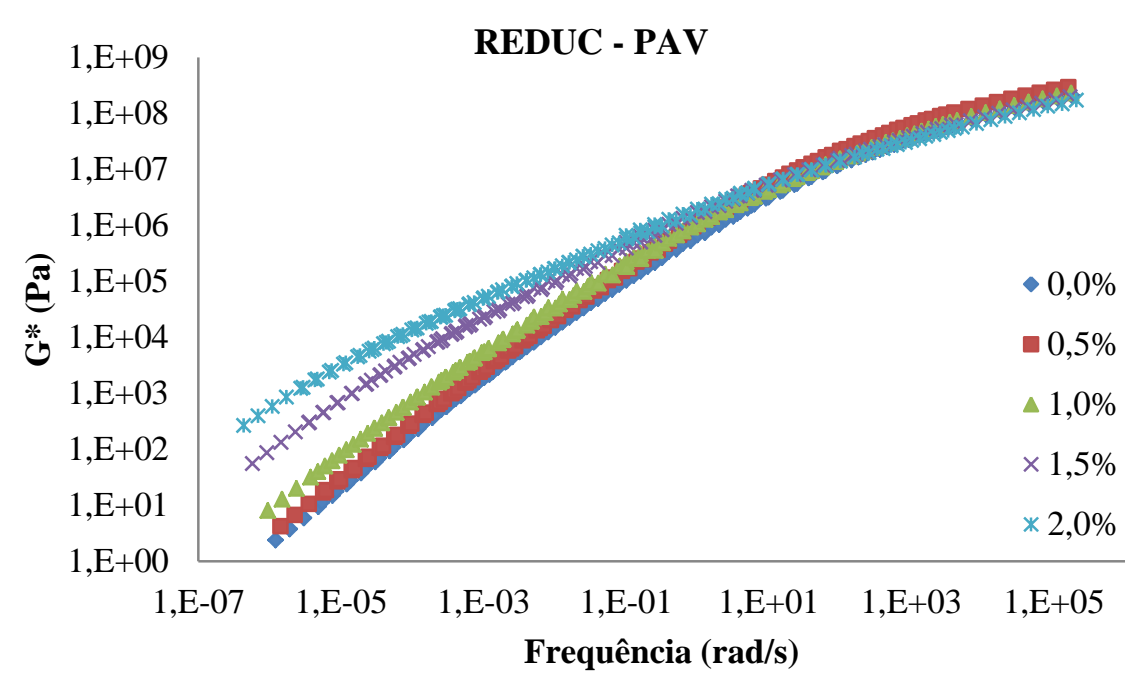

Figura 4.15 - Variação de $\mathrm{G}^{*}$ em função da frequência para REDUC envelhecidos no PAV, modificados com cinco teores de PPA 
Nas frequências altas (temperatura baixas), o efeito da adição de PPA é inexpressivo e todos os ligantes asfálticos tendem a um valor máximo de rigidez, o que se reflete em um também inexpressivo efeito sobre a resistência ao trincamento de origem térmica. Como também observado para o LUBNOR, nas temperaturas altas, o efeito enrijecedor do envelhecimento se soma ao efeito enrijecedor do PPA, favorecendo o aumento da resistência à deformação permanente das misturas asfálticas.

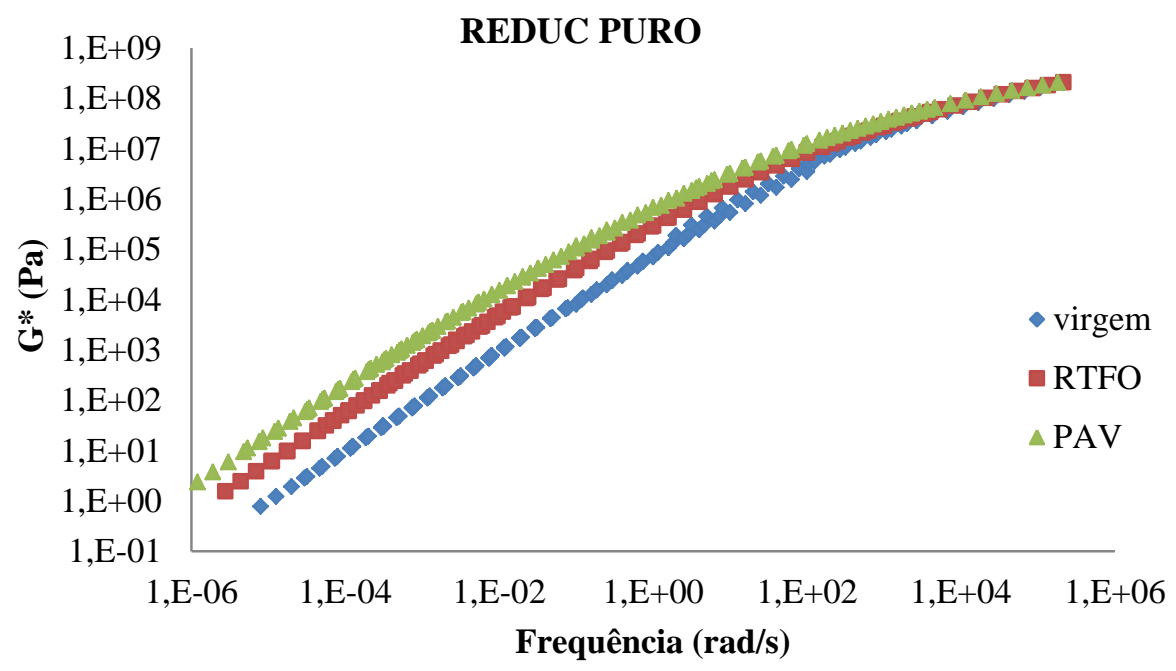

Figura 4.16 - Variação de G* em função da frequência para REDUC não-envelhecido e envelhecido no RTFOT e PAV

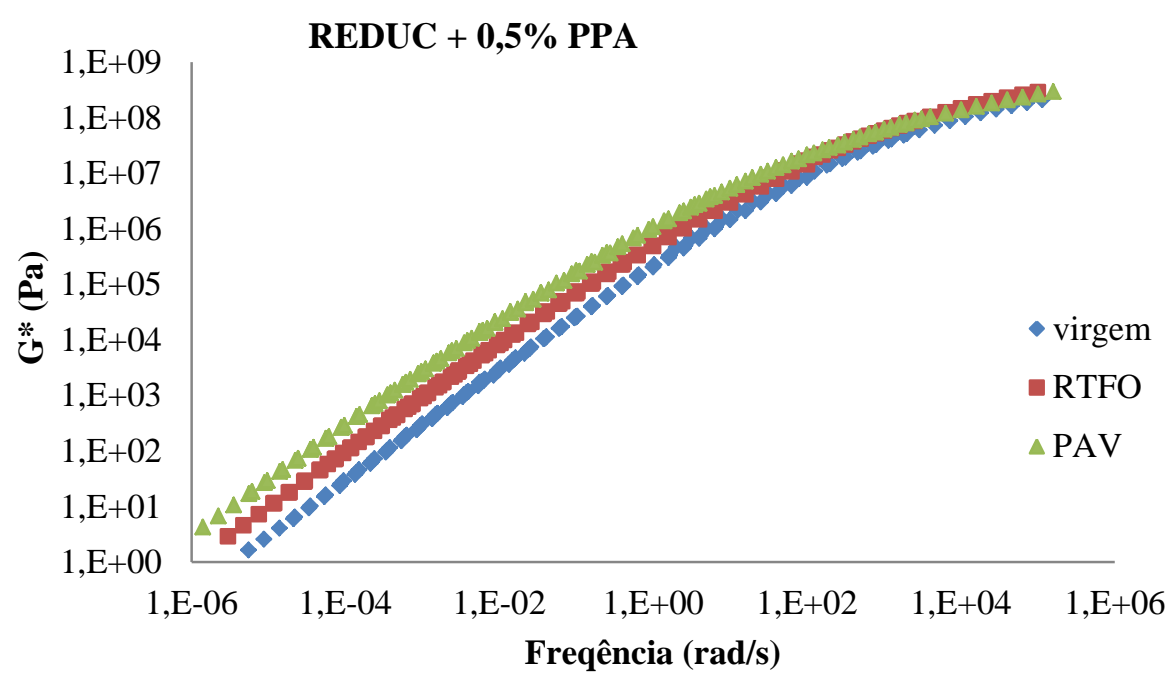

Figura 4.17 - Variação de G* em função da frequência para REDUC, modificados com 0.5\% de PPA, nãoenvelhecido e envelhecidos no RTFOT e PAV 


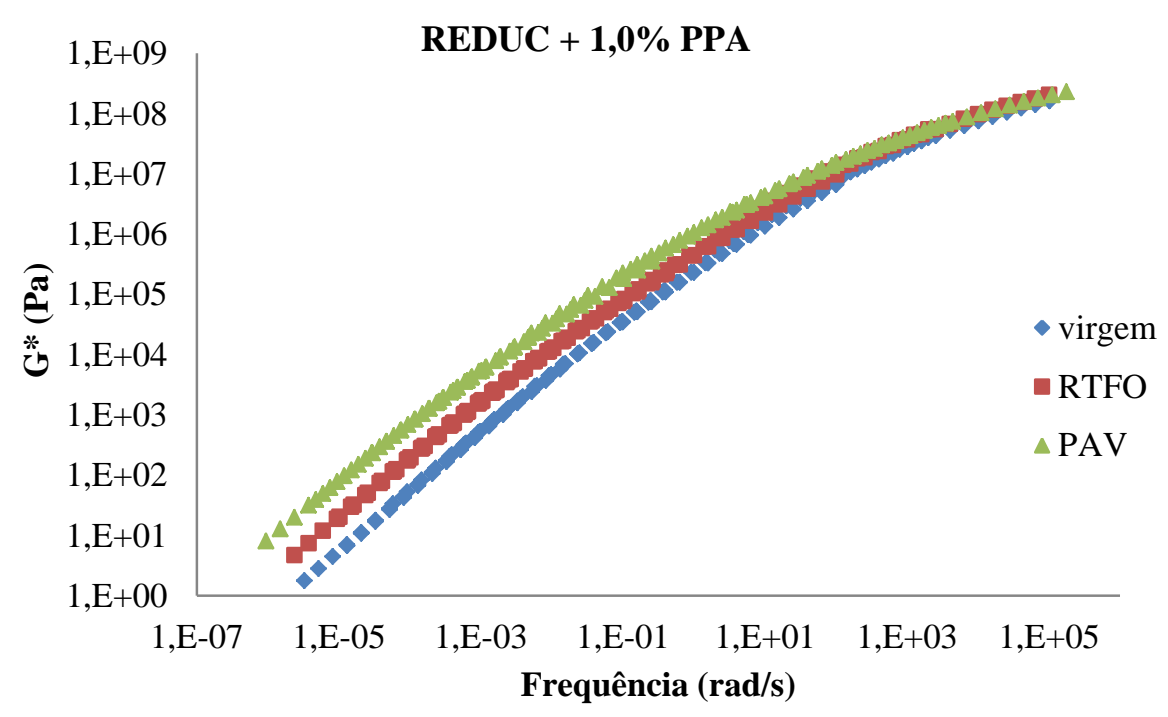

Figura 4.18 - Variação de $\mathrm{G}^{*}$ em função da frequência para REDUC, modificados com 1.0\% de PPA, nãoenvelhecido e envelhecidos no RTFOT e PAV

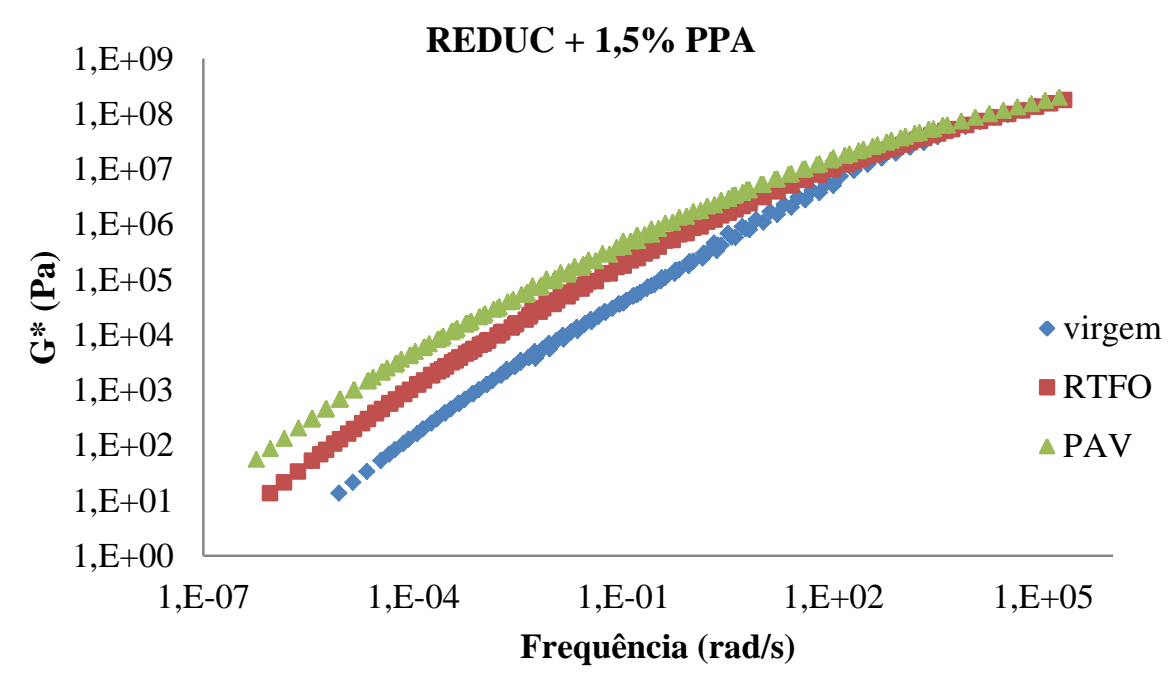

Figura 4.19 - Variação de $\mathrm{G}^{*}$ em função da frequência para REDUC, modificados com 1.5\% de PPA, nãoenvelhecido e envelhecidos no RTFOT e PAV

As Figuras 4.21, 4.22 e 4.23 apresentam o efeito na elasticidade da adição de diferentes teores de PPA no ligante asfáltico da LUBNOR, não-envelhecido, envelhecido no RTFOT e envelhecido no PAV respectivamente. As Figuras 4.31, 4.32, 4.33 mostram que a adição de PPA e o envelhecimento favorecem o aumento da elasticidade, com a redução dos valores do ângulo de fase ao longo do espectro de frequências. 


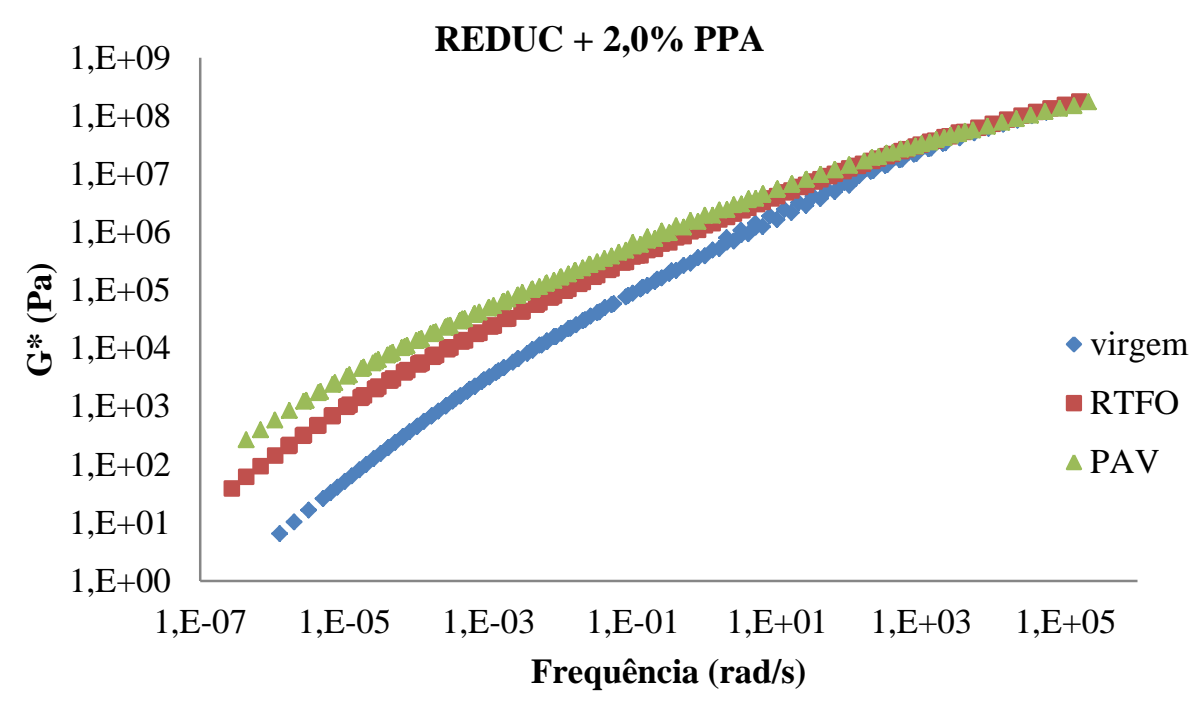

Figura 4.20 - Variação de G* em função da frequência para REDUC, modificados com $2.0 \%$ de PPA, nãoenvelhecido e envelhecidos no RTFOT e PAV

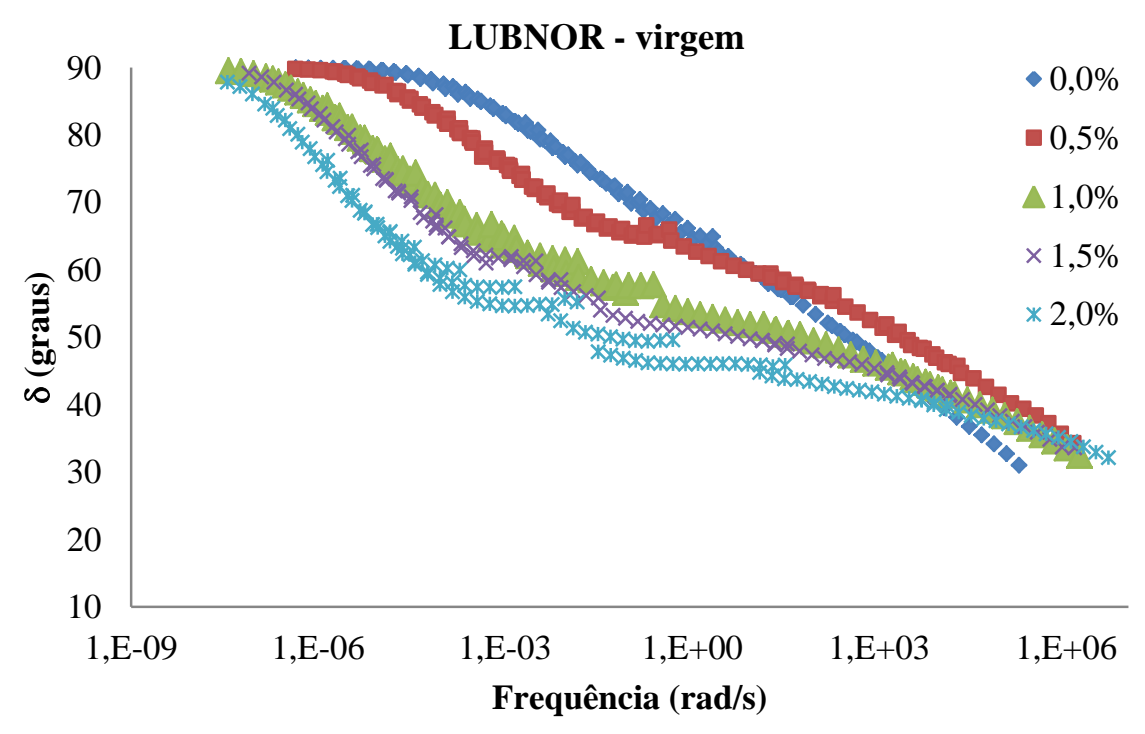

Figura 4.21 - Variação de $\delta$ em função da frequência para LUBNOR não-envelhecidos, modificados com cinco teores de PPA

Tal fato é vantajoso em termos de durabilidade da camada asfáltica, já que um material mais elástico favorece tanto a resistência à deformação permanente quanto à fadiga e ao trincamento térmico. Dado o alto grau de modificação devido à incorporação de PPA, verifica-se um desvio em relação ao princípio de superposição tempo-temperatura, que leva ao ajuste ruim das curvas-mestre de delta das formulações com maior concentração de ácido. 


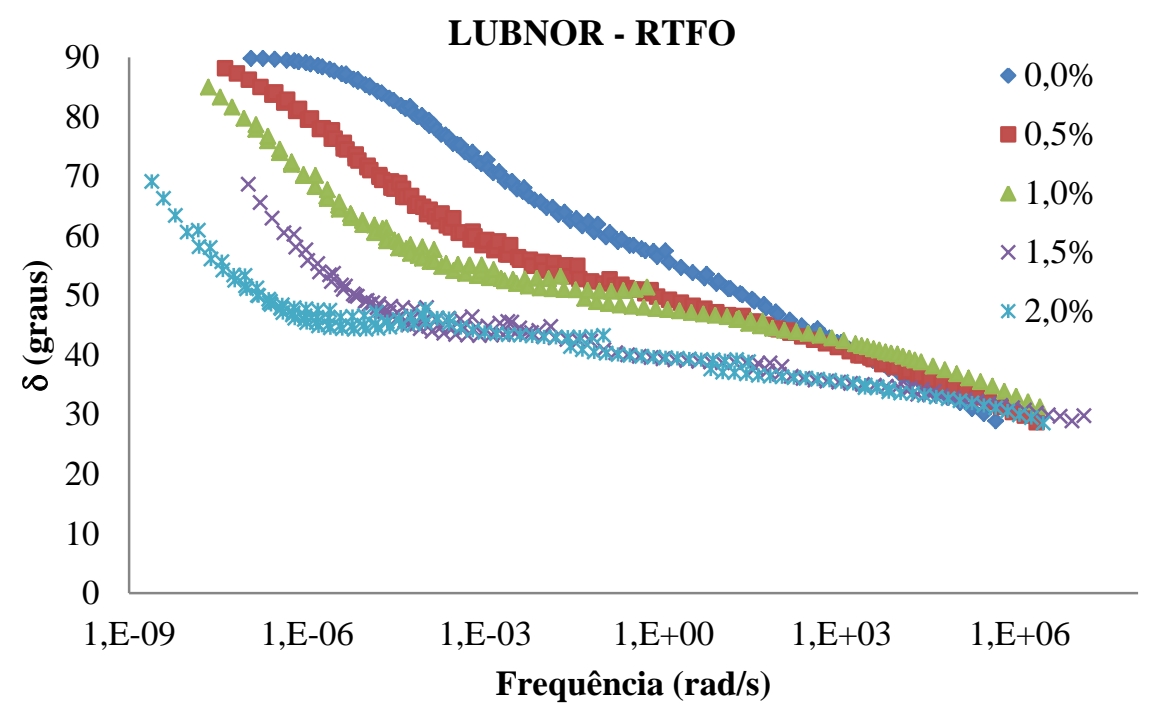

Figura 4.22 - Variação de $\delta$ em função da frequência para LUBNOR envelhecidos no RTFOT, modificados com cinco teores de PPA

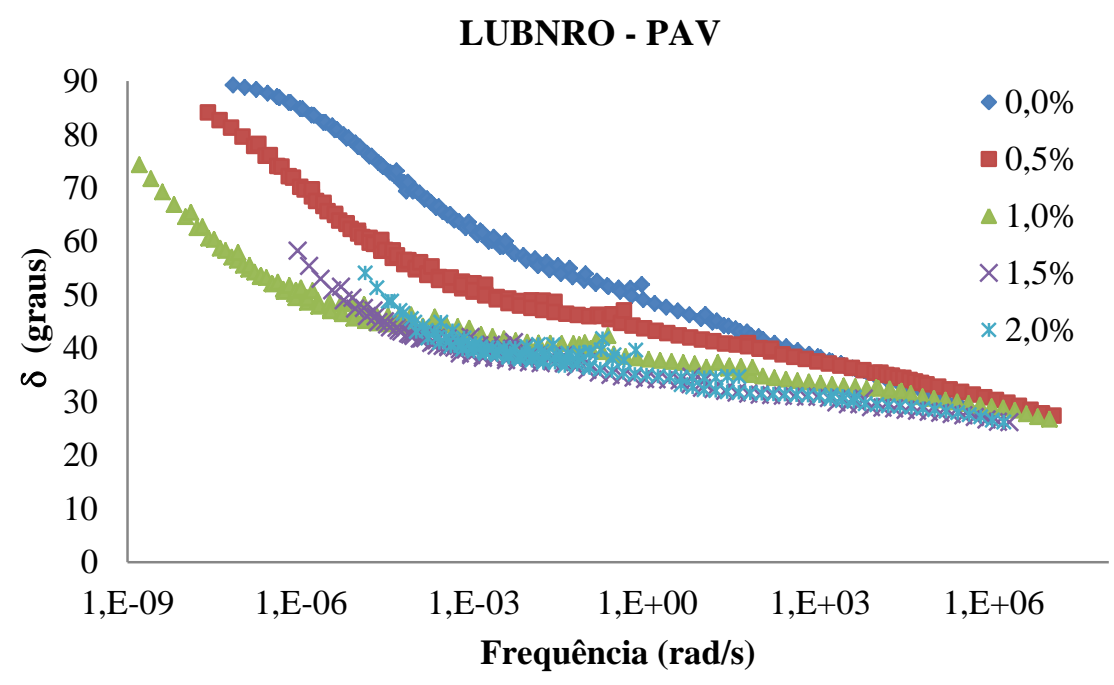

Figura 4.23 - Variação de $\delta$ em função da frequência para LUBNOR envelhecidos no PAV, modificados com cinco teores de PPA

As Figuras de 4.24 a 4.28 apresentam a variação da elasticidade dos ligantes asfálticos em função da frequência para os ligantes asfálticos da LUBNOR, puro e modificados, virgens e envelhecidos a curto e longo prazo. Observa-se que o envelhecimento termo-oxidativo promove um aumento na elasticidade dos ligantes asfálticos evidenciado pela diminuição do $\delta$ com o envelhecimento termo-oxidativo das amostras. Logo, em termos de elasticidade, o 
envelhecimento tornaria o ligante asfáltico mais resistente à deformação permanente, à fadiga e ao trincamento térmico.

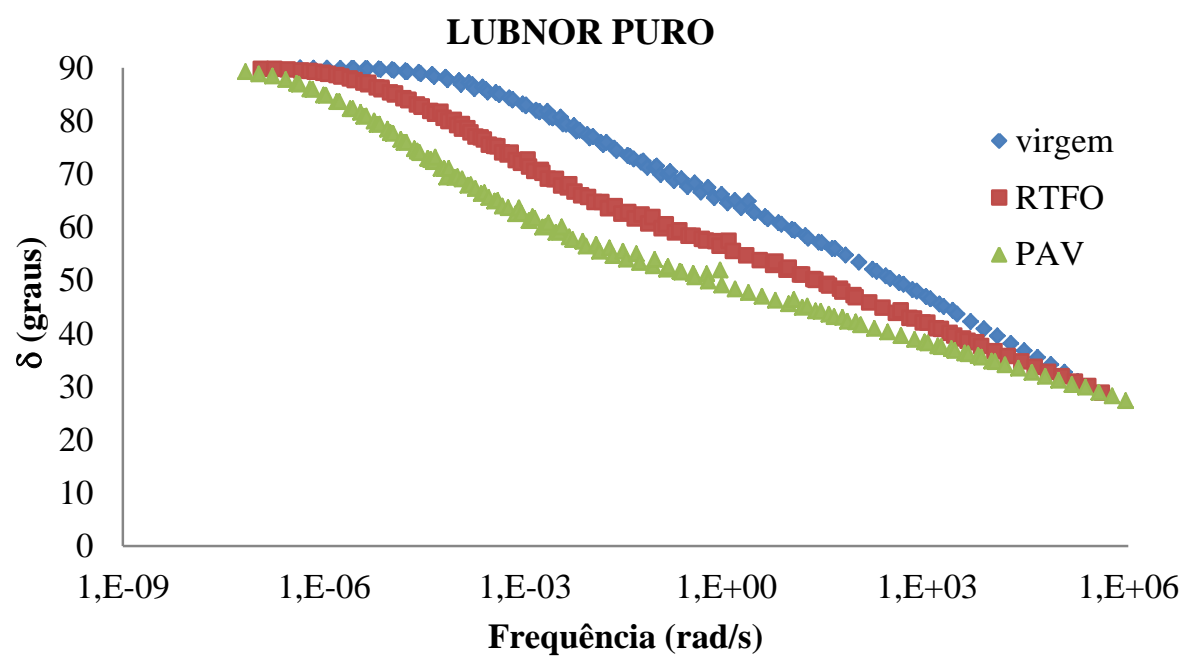

Figura 4.24 - Variação de $\delta$ em função da frequência para LUBNOR não-envelhecido e envelhecidos no RTFOT e PAV

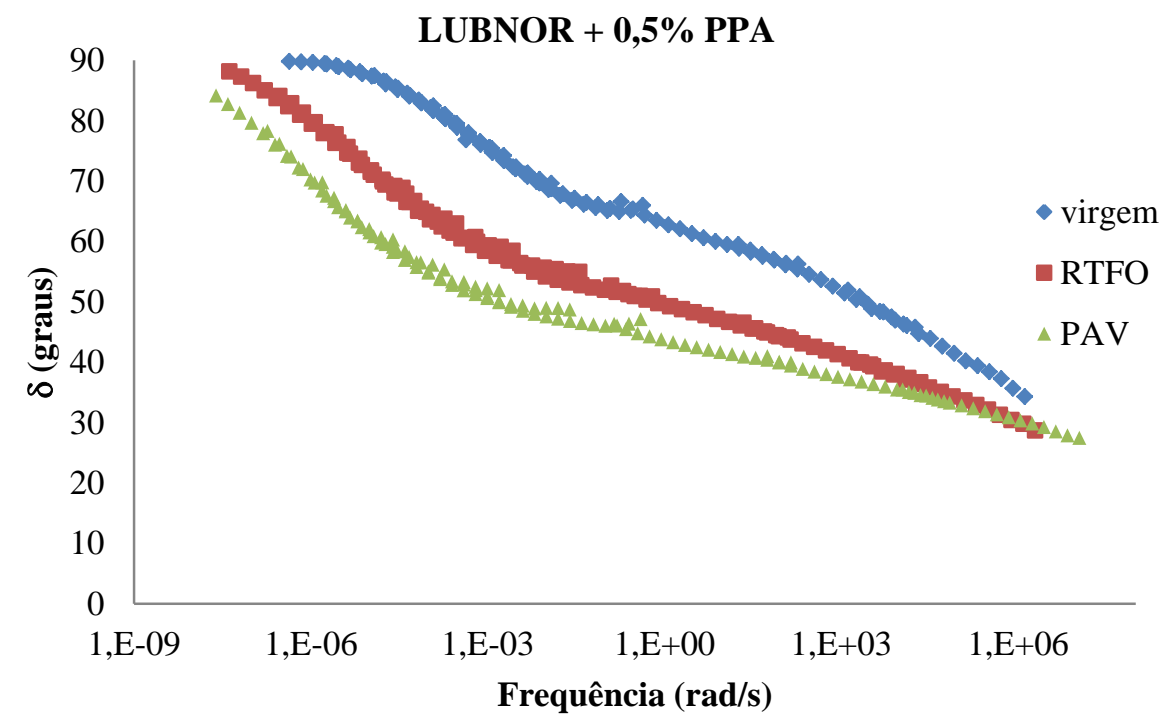

Figura 4.25 - Variação de $\delta$ em função da frequência para LUBNOR, modificado com $0,5 \%$ de PPA, nãoenvelhecido e envelhecidos no RTFOT e PAV

As Figuras 4.29, 4.30 e 4.31 apresentam o efeito na elasticidade da adição de diferentes teores de PPA no ligante asfáltico da REDUC, virgens, envelhecido no RTFOT e envelhecido no PAV respectivamente. As Figuras de 4.29 a 4.31 mostram que, assim como 
foi observado para o LUBNOR, a adição de PPA e o envelhecimento favorecem o aumento da elasticidade, evidenciado pela redução dos valores do ângulo de fase ao longo do espectro de frequências. Tal fato é vantajoso em termos de durabilidade da camada asfáltica, já que uma maior elasticidade do ligante asfáltico favorece a resistência à deformação permanente, à fadiga e ao trincamento térmico. Mais uma vez verifica-se um desvio em relação ao princípio de superposição tempo-temperatura devido ao alto teor de PPA, que leva ao ajuste ruim das curvas-mestre de delta das formulações com maior concentração de ácido.

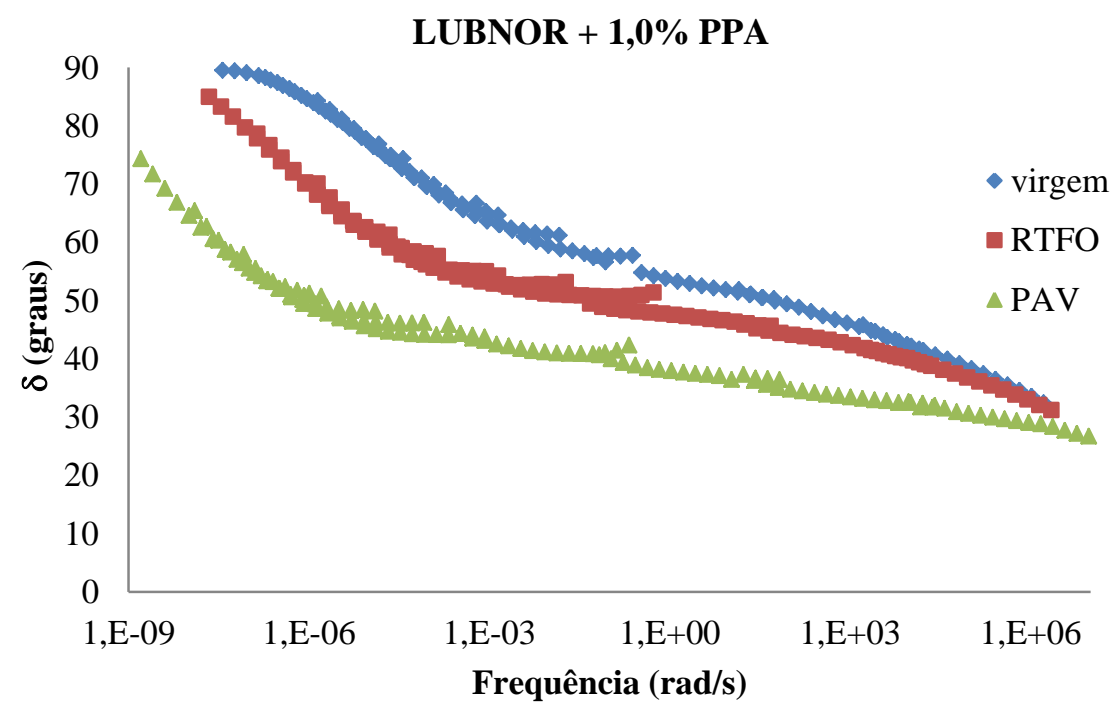

Figura 4.26 - Variação de $\delta$ em função da frequência para LUBNOR, modificado com 1,0\% de PPA, nãoenvelhecido e envelhecidos no RTFOT e PAV

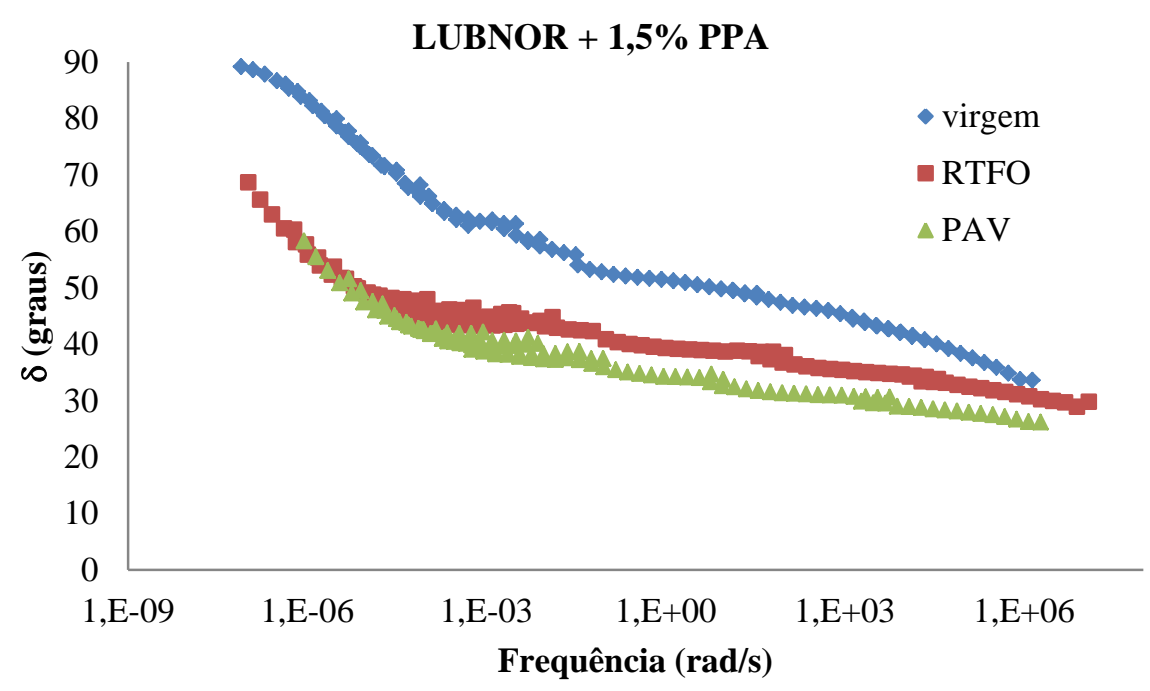

Figura 4.27 - Variação de $\delta$ em função da frequência para LUBNOR, modificado com 1,5\% de PPA, nãoenvelhecido e envelhecidos no RTFOT e PAV 
LUBNOR + 2,0\% PPA

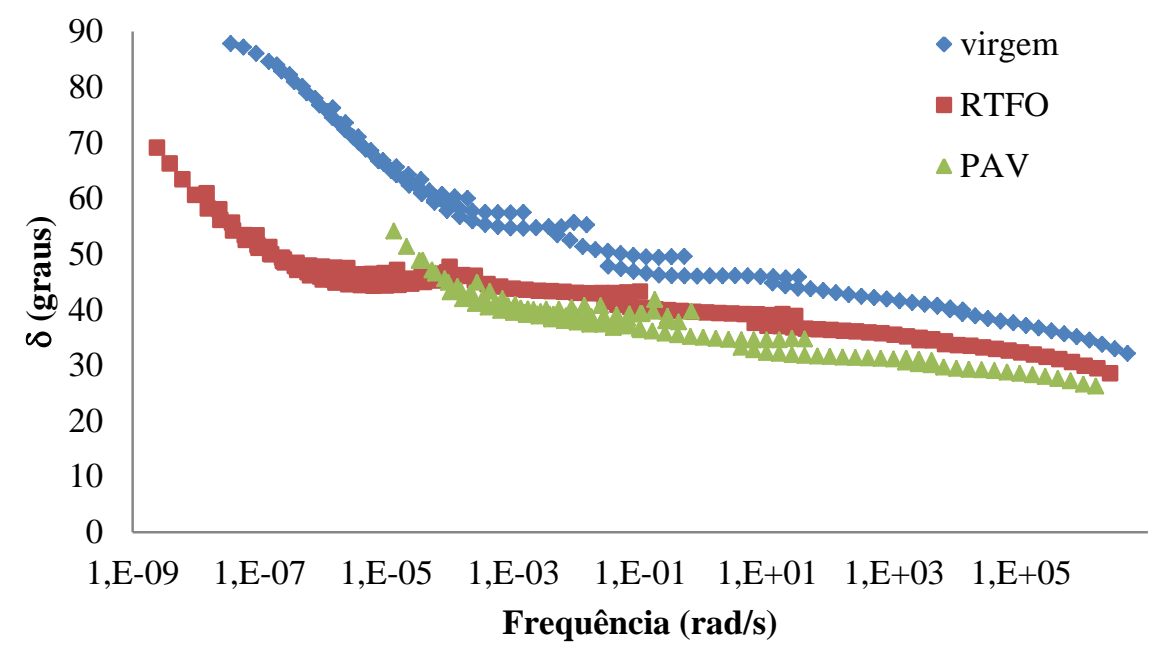

Figura 4.28 - Variação de $\delta$ em função da frequência para LUBNOR, modificado com 2,0\% de PPA, nãoenvelhecido e envelhecidos no RTFOT e PAV

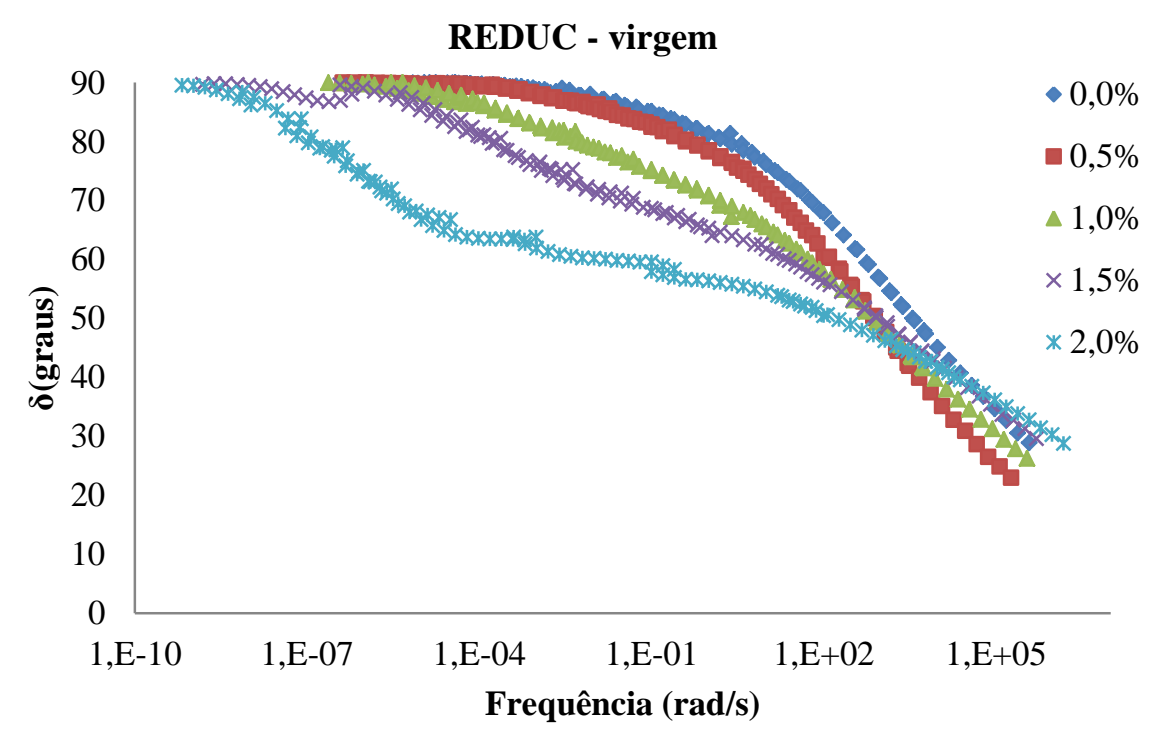

Figura 4.29 - Variação de $\delta$ em função da frequência para REDUC, não-envelhecidos, modificados com cinco teores de PPA

As Figuras de 4.32 a 4.36 apresentam a variação da elasticidade dos ligantes asfálticos em função da frequência para os ligantes asfálticos da REDUC, puro e modificados, virgens e envelhecidos a curto e longo prazo. Assim como foi observado para o ligante asfáltico da LUBNOR, observa-se um aumento na elasticidade dos ligantes asfálticos promovido pelo envelhecimento termo-oxidativo, evidenciado pela diminuição do $\delta$ das amostras. Em termos 
de elasticidade, o envelhecimento tornaria o ligante asfáltico mais resistente à deformação permanente, à fadiga e ao trincamento térmico.

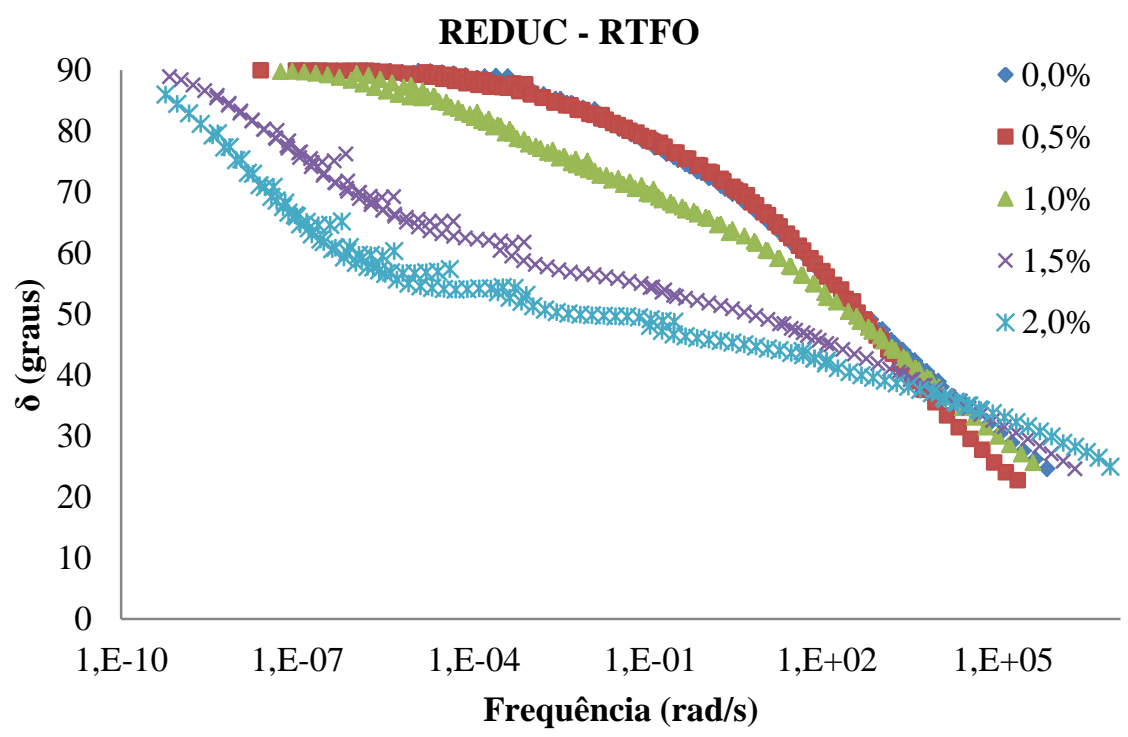

Figura 4.30 - Variação de $\delta$ em função da frequência para REDUC, envelhecidos no RTFOT, modificados com cinco teores de PPA

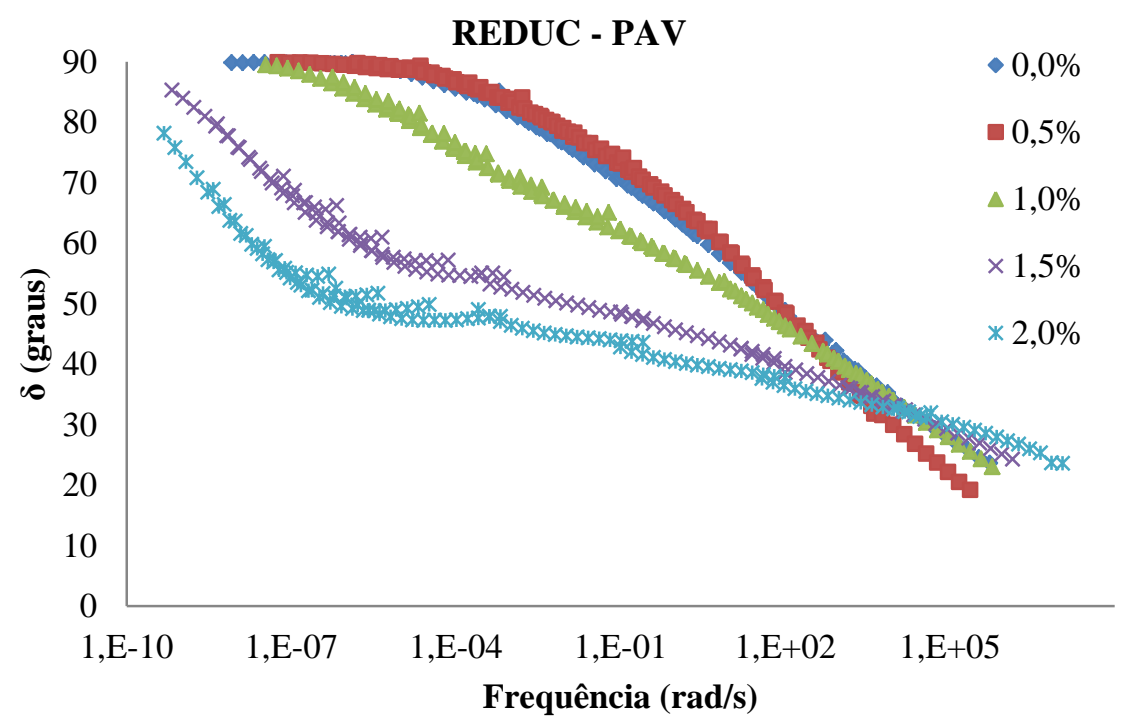

Figura 4.31 - Variação de $\delta$ em função da frequência para REDUC, envelhecidos no PAV, modificados com cinco teores de PPA 


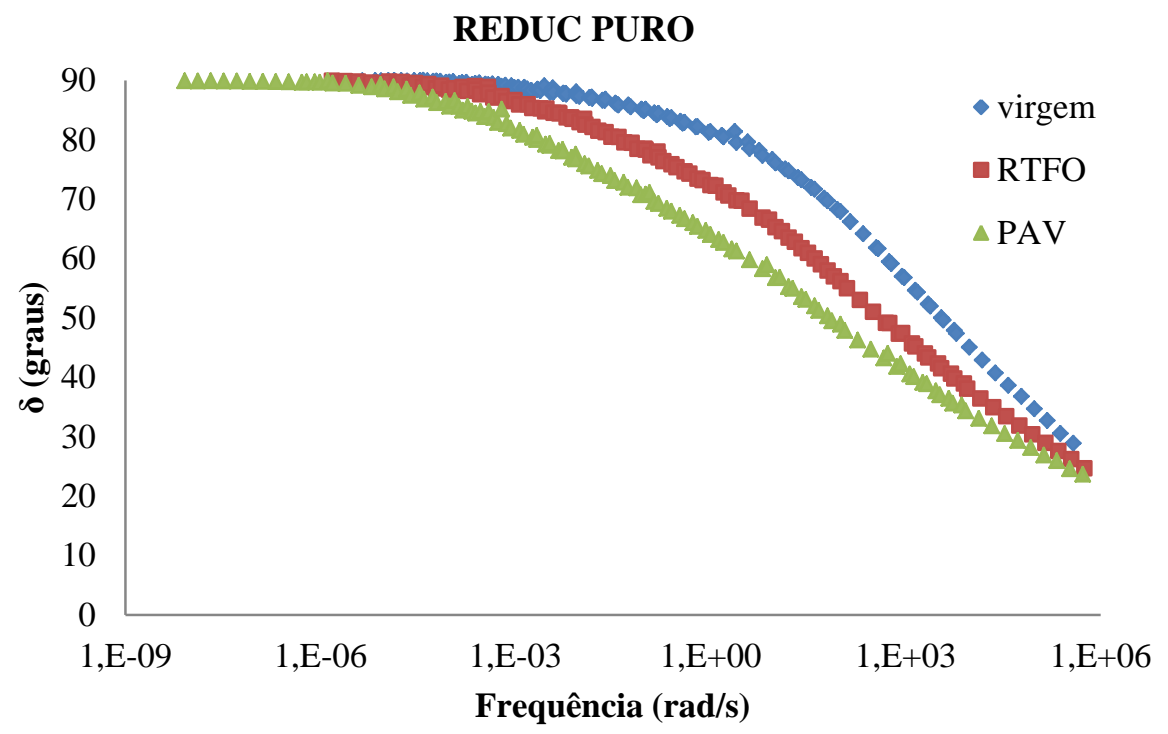

Figura 4.32 - Variação de $\delta$ em função da frequência para REDUC não-envelhecido e envelhecidos no RTFOT e PAV

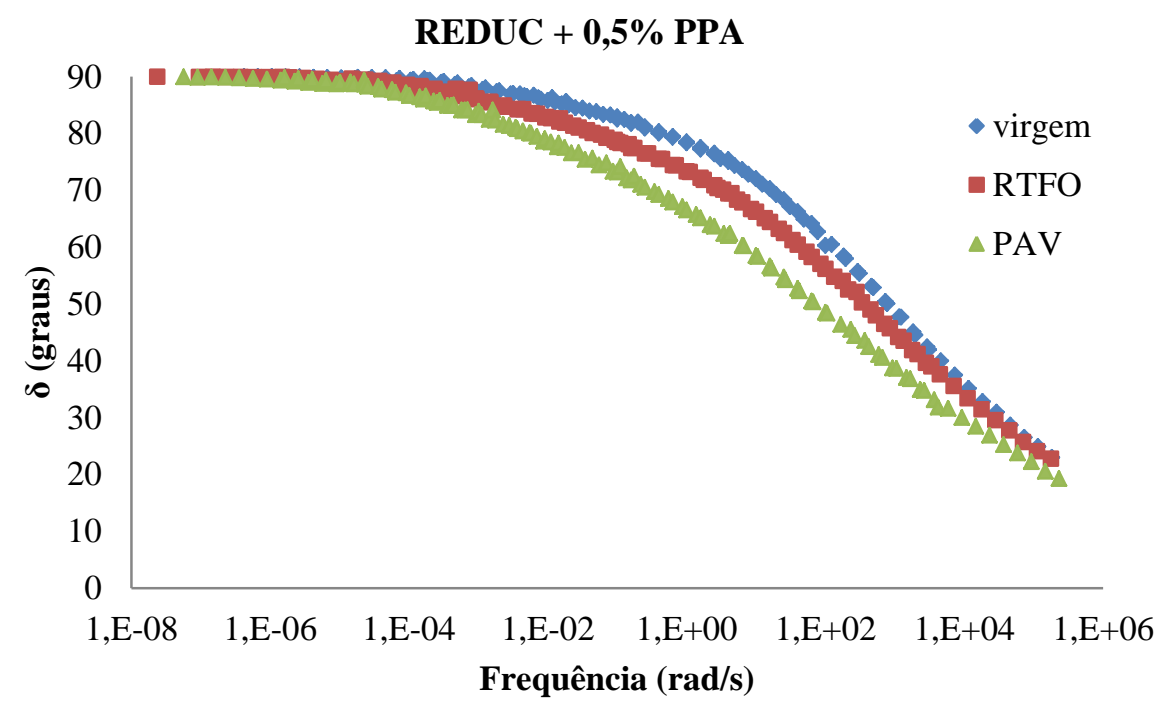

Figura 4.33 - Variação de $\delta$ em função da frequência para REDUC, modificado com $0,5 \%$ de PPA, nãoenvelhecido e envelhecidos no RTFOT e PAV

$\mathrm{Na}$ análise a seguir é feita uma avaliação do efeito do teor de PPA sobre a rigidez dos ligantes asfálticos, em função da frequência de carregamento, para uma dada temperatura de referência, com base nos dados obtidos das curvas-mestre. O objetivo é avaliar como a frequência de carregamento influencia o efeito enrijecedor do PPA sobre os dois ligantes asfálticos em estudo. 


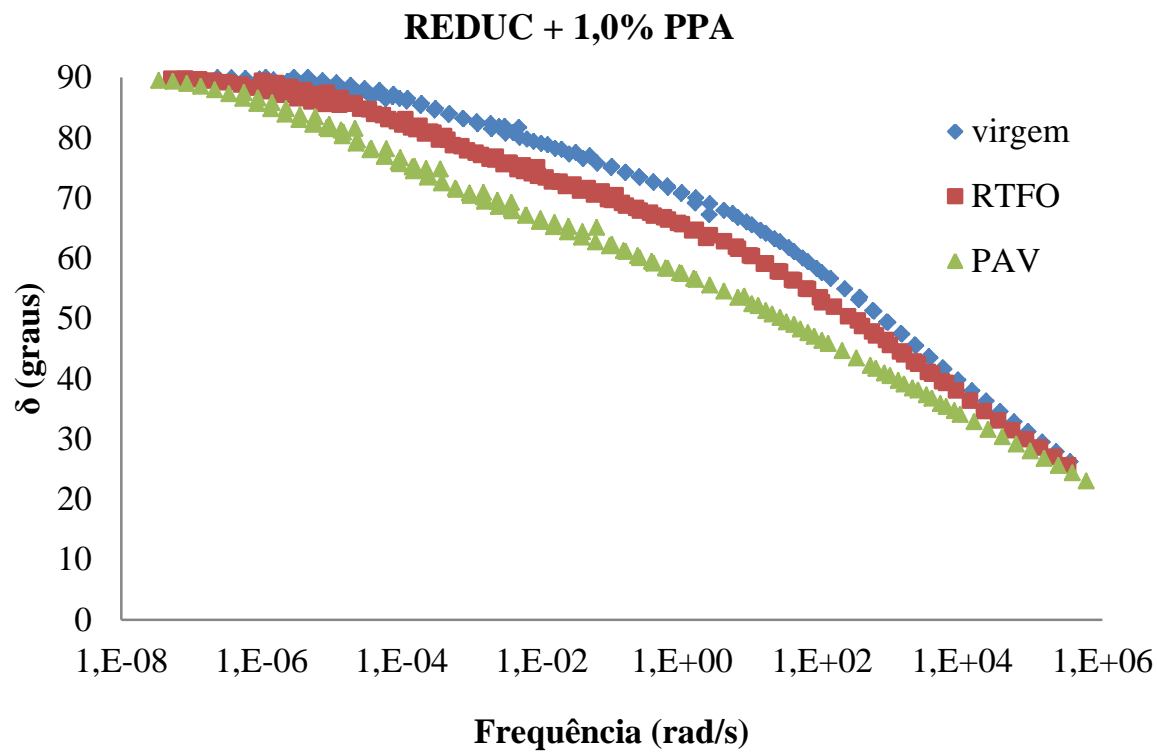

Figura 4.34 - Variação de $\delta$ em função da frequência para REDUC, modificado com 1,0\% de PPA, nãoenvelhecido e envelhecidos no RTFOT e PAV

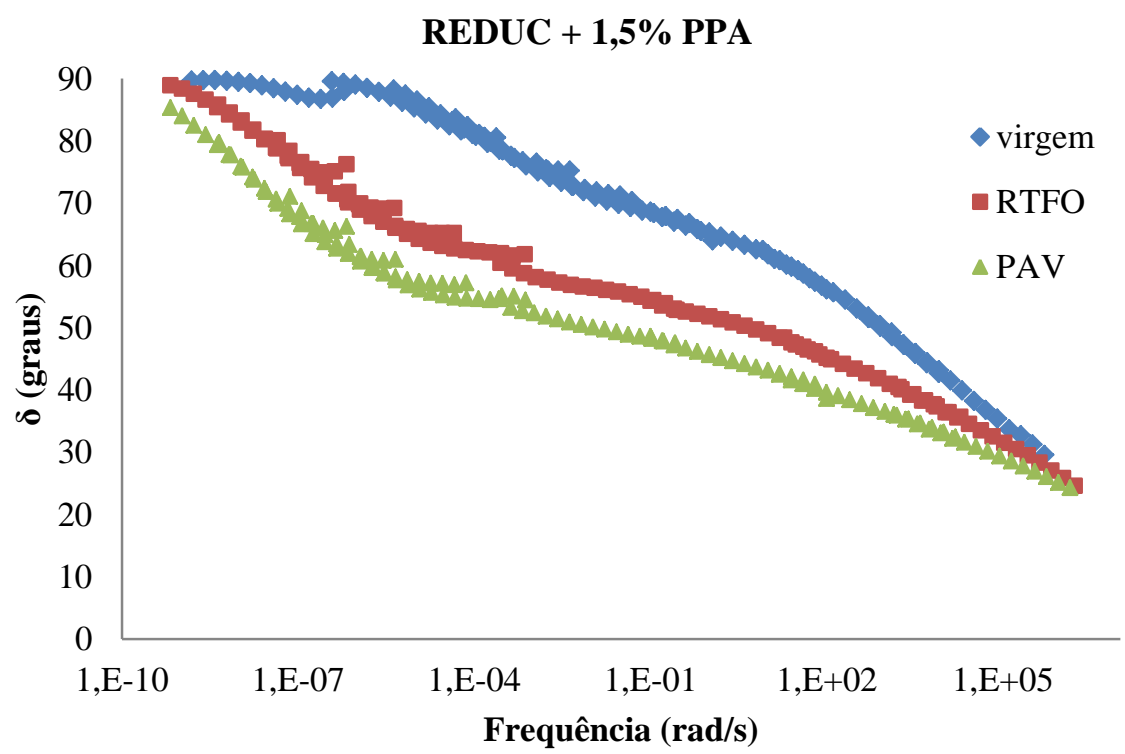

Figura 4.35 - Variação de $\delta$ em função da frequência para REDUC, modificado com 1,5\% de PPA, nãoenvelhecido e envelhecidos no RTFOT e PAV

A Tabela 4.6 apresenta as variações de $\mathrm{G}^{*}$ do LUBNOR modificado com os quatro teores de PPA, na condição virgem, comparativamente ao LUBNOR puro, também na condição virgem. A Tabela 4.7 apresenta o mesmo tipo de comparação para o REDUC. A variação de $G^{*}$ é expressa em termos de quantas vezes $G^{*}$ aumentou ou diminuiu por conta 
da adição de PPA, em função da frequência de carregamento, a $25^{\circ} \mathrm{C}$, em relação aos valores de rigidez do ligante asfáltico de base. Valores acima de 1,0 indicam enrijecimento em relação ao ligante asfáltico de base devido à adição de PPA e valores inferiores a 1,0 indicam que o ligante asfáltico modificado é menos rígido que o puro. Na coluna referente ao teor de $0,0 \%$ de PPA estão indicados os valores originais de $G^{*}$ e nas linhas dos demais teores estão as relações. As análises foram feitas na frequência de $0,1 \mathrm{rad} / \mathrm{s}$ (frequência baixa, correspondente a tráfego lento) e na frequência de $10 \mathrm{rad} / \mathrm{s}$ (frequência alta, correspondente a tráfego rápido).

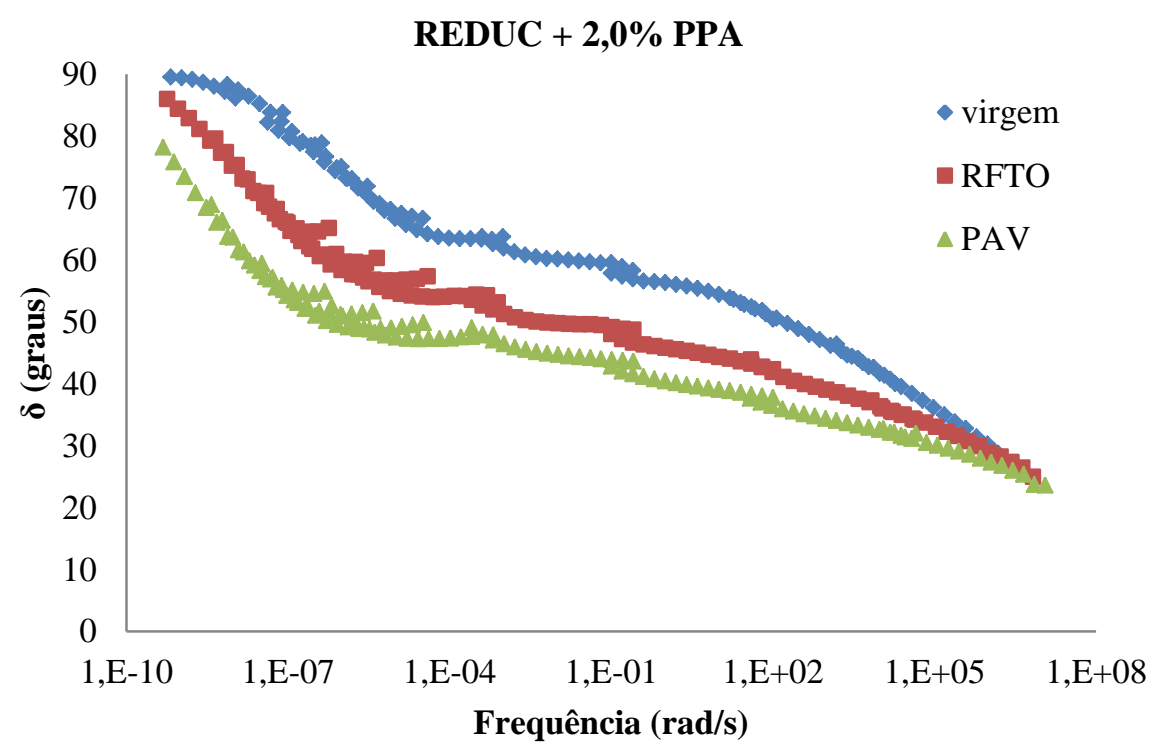

Figura 4.36 - Variação de $\delta$ em função da frequência para REDUC, modificado com 2,0\% de PPA, nãoenvelhecido e envelhecidos no RTFOT e PAV

Na frequência de 0,1 rad/s, a adição de 0,5 e 1,0\% de PPA no LUBNOR não provoca um enrijecimento expressivo do ligante asfáltico, enquanto no caso do REDUC, a adição de 0,5 e 1,0\% de PPA enrijece o ligante asfáltico em aproximadamente 3 e 4 vezes, respectivamente. O LUBNOR modificado com 1,5\% de PPA é, aproximadamente, 2 vezes mais rígido que o LUBNOR puro e o REDUC modificado com 1,5\% de PPA é, aproximadamente, 5 vezes mais rígido que o REDUC puro. O LUBNOR modificado com 2,0\% de PPA é, aproximadamente, 4 vezes mais rígido que o LUBNOR puro e o REDUC modificado com 2,0\% de PPA é, aproximadamente, 11 vezes mais rígido que o REDUC puro. A partir destes resultados, observa-se que o REDUC é muito mais sensível à adição de PPA, em termos de rigidez, em todo o espectro de frequência. 
Tabela 4.6 - Variações dos valores de $\mathrm{G}^{*}$ para o LUBNOR puro e modificados com PPA, a $25^{\circ} \mathrm{C}$, na condição virgem

\begin{tabular}{cccccc}
\hline Frequência & \multicolumn{5}{c}{ teor de PPA (\%) } \\
\cline { 2 - 6 } angular (rad/s) & $\mathbf{0 , 0}$ & $\mathbf{0 , 5}$ & $\mathbf{1 , 0}$ & $\mathbf{1 , 5}$ & $\mathbf{2 , 0}$ \\
\hline $10^{-5}$ & $1,1.10$ & 1,7 & 3,7 & 8,5 & 39,9 \\
$10^{-4}$ & $1,1.10^{2}$ & 1,6 & 3,3 & 6,9 & 25,2 \\
$10^{-3}$ & $1,1.10^{3}$ & 1,5 & 2,5 & 4,4 & 12,7 \\
$10^{-2}$ & $8,9.10^{3}$ & 1,2 & 1,8 & 2,7 & 7,4 \\
$\mathbf{1 0}^{-1}$ & $\mathbf{6 , 0 . 1 0}^{\mathbf{4}}$ & $\mathbf{1 , 1}$ & $\mathbf{1 , 3}$ & $\mathbf{1 , 8}$ & $\mathbf{3 , 9}$ \\
$10^{0}$ & $3,9.10^{5}$ & 0,9 & 0,9 & 1,0 & 2,2 \\
$\mathbf{1 0}^{\mathbf{1}}$ & $\mathbf{1 , 9 . 1 0 ^ { \mathbf { 6 } }}$ & $\mathbf{0 , 8}$ & $\mathbf{0 , 7}$ & $\mathbf{0 , 8}$ & $\mathbf{1 , 5}$ \\
$10^{2}$ & $7,5.10^{6}$ & 0,8 & 0,6 & 0,7 & 1,1 \\
$10^{3}$ & $2,5.10^{7}$ & 0,8 & 0,6 & 0,8 & 0,9 \\
$10^{4}$ & $6,9.10^{7}$ & 1,0 & 0,6 & 0,7 & 0,8 \\
\hline
\end{tabular}

$\mathrm{Na}$ frequência de $10 \mathrm{rad} / \mathrm{s}$, frequência relacionada a uma velocidade de tráfego de 90 $\mathrm{km} / \mathrm{h}$, a adição de teores entre 0,5 e $1,5 \%$ de PPA no LUBNOR reduz a rigidez a aproximadamente $80 \%$ da rigidez do ligante asfáltico puro. No teor de 2,0\%, o LUBNOR apresenta rigidez 1,5 vezes maior que o CAP puro. No caso do REDUC, o aumento da rigidez varia entre 2 e 3 vezes, dependendo do teor de PPA adicionado. Nas frequências mais altas (temperaturas baixas) o efeito enrijecedor do PPA no LUBNOR é invertido, uma vez que os ligantes asfálticos modificados são menos rígidos que o LUBNOR puro.

Tabela 4.7 - Variações dos valores de $\mathrm{G}^{*}$ para o REDUC puro e modificados com PPA, a $25^{\circ} \mathrm{C}$, na condição virgem

\begin{tabular}{cccccc}
\hline \multirow{2}{*}{$\begin{array}{c}\text { Frequência } \\
\text { angular }(\mathbf{r a d} / \mathbf{s})\end{array}$} & $\mathbf{0 , 0}$ & $\mathbf{0 , 5}$ & $\mathbf{1 , 0}$ & $\mathbf{1 , 5}$ & $\mathbf{2 , 0}$ \\
\cline { 2 - 6 } & $9,8.10^{-1}$ & 3,0 & 5,6 & 16,0 & 52,1 \\
$10^{-5}$ & $9,6.10^{0}$ & 3,1 & 5,9 & 15,2 & 46,4 \\
$10^{-4}$ & $9,6.10^{1}$ & 3,2 & 5,7 & 12,0 & 32,9 \\
$10^{-3}$ & $9,8.10^{2}$ & 3,0 & 4,9 & 6,9 & 18,2 \\
$10^{-2}$ & $\mathbf{8 , 1 . 1 0 ^ { 3 }}$ & $\mathbf{3 , 2}$ & $\mathbf{4 , 3}$ & $\mathbf{4 , 7}$ & $\mathbf{1 1 , 0}$ \\
$\mathbf{1 0}^{-1}$ & $7,0.10^{4}$ & 2,9 & 3,3 & 3,0 & 5,5 \\
$10^{0}$ & $\mathbf{5 , 4 . 1 0 ^ { 5 }}$ & $\mathbf{2 , 7}$ & $\mathbf{2 , 5}$ & $\mathbf{2 , 0}$ & $\mathbf{3 , 0}$ \\
$\mathbf{1 0}^{\mathbf{1}}$ & $3,5.10^{6}$ & 2,4 & 1,9 & 1,4 & 1,8 \\
$10^{2}$ & $2,1.10^{7}$ & 1,7 & 1,3 & 1,1 & 1,1 \\
$10^{3}$ & $6,6.10^{7}$ & 1,5 & 1,1 & 1,0 & 1,0 \\
$10^{4}$ & & & & &
\end{tabular}


Em termos de resistência à deformação permanente, apesar do REDUC ser mais sensível à adição de PPA, o LUBNOR é mais rígido por natureza, o que se refletiria em uma maior resistência à deformação permanente. Esta constatação também pode ser observada com base nos resultados de MSCR.

A Tabela 4.8 apresenta as variações de $\mathrm{G}^{*}$ do LUBNOR modificado com os quatro teores de PPA, envelhecido a curto prazo, comparativamente ao LUBNOR puro, também envelhecido a curto prazo. A Tabela 4.9 apresenta o mesmo tipo de comparação para o REDUC. As análises foram feitas seguindo a mesma linha de raciocínio utilizada na análise anterior.

Tabela 4.8 - Variações dos valores de $\mathrm{G}^{*}$ para o LUBNOR puro e modificados com PPA, a $25^{\circ} \mathrm{C}$, envelhecido no RTFOT

\begin{tabular}{cccccc}
\hline \multirow{2}{*}{$\begin{array}{c}\text { Frequência } \\
\text { angular }(\mathbf{r a d} / \mathbf{s})\end{array}$} & $\mathbf{0 , 0}$ & $\mathbf{0 , 5}$ & $\mathbf{1 , 0}$ & $\mathbf{1 , 5}$ & $\mathbf{2 , 0}$ \\
\cline { 2 - 6 } & $8,32.10^{1}$ & 3,6 & 7,4 & 3,6 & 61,9 \\
$10^{-5}$ & $7,74.10^{2}$ & 2,8 & 4,7 & 2,8 & 23,1 \\
$10^{-4}$ & $6,26.10^{3}$ & 1,9 & 2,7 & 1,9 & 9,1 \\
$10^{-3}$ & $3,93.10^{4}$ & 1,4 & 1,8 & 1,4 & 4,7 \\
$10^{-2}$ & $\mathbf{2 , 0 8 . 1 0}^{\mathbf{5}}$ & $\mathbf{1 , 1}$ & $\mathbf{1 , 3}$ & $\mathbf{1 , 1}$ & $\mathbf{2 , 8}$ \\
$\mathbf{1 0}^{-\mathbf{1}}$ & $1,00.10^{6}$ & 0,8 & 0,9 & 0,8 & 1,7 \\
$10^{0}$ & $\mathbf{3 , 7 4 . 1 0}^{\mathbf{6}}$ & $\mathbf{0 , 8}$ & $\mathbf{0 , 8}$ & $\mathbf{0 , 8}$ & $\mathbf{1 , 3}$ \\
$\mathbf{1 0}^{\mathbf{1}}$ & $1,23.10^{7}$ & 0,7 & 0,7 & 0,7 & 1,1 \\
$10^{2}$ & $3,47.10^{7}$ & 0,8 & 0,7 & 0,8 & 0,9 \\
$10^{3}$ & $8,02.10^{7}$ & 0,8 & 0,8 & 0,8 & 0,9 \\
$10^{4}$ & & & & & \\
\hline
\end{tabular}

$\mathrm{Na}$ frequência de $0,1 \mathrm{rad} / \mathrm{s}$, a adição de $0,5,1,0,1,5 \%$ de PPA no LUBNOR não provoca um enrijecimento expressivo do ligante asfáltico, enquanto no caso do REDUC, a adição de 0,5 e 1,0\% de PPA enrijece o ligante asfáltico em aproximadamente 1,5 vezes e a adição de 1,5\% de PPA enrijece o ligante asfáltico em aproximadamente 5 vezes. O LUBNOR modificado com 2,0\% de PPA é, aproximadamente, 3 vezes mais rígido que o LUBNOR puro e o REDUC modificado com 2,0\% de PPA é, aproximadamente, 9 vezes mais rígido que o REDUC puro.

Assim como na condição virgem, observa-se que o REDUC é muito mais sensível à adição de PPA, em termos de rigidez, em todo o espectro de frequência. Na frequência de 10 $\mathrm{rad} / \mathrm{s}$, frequência relacionada a uma velocidade de tráfego de $90 \mathrm{~km} / \mathrm{h}$, a adição de teores entre 
0,5 e 1,5\% de PPA no LUBNOR reduz, assim como na condição virgem, a rigidez a aproximadamente $80 \%$ da rigidez do ligante asfáltico puro. No teor de 2,0\%, o LUBNOR apresenta rigidez 1,3 vezes maior que o CAP puro.

Tabela 4.9 - Variações dos valores de $\mathrm{G}^{*}$ para o REDUC puro e modificados com PPA, a $25^{\circ} \mathrm{C}$, envelhecido no RTFOT

\begin{tabular}{cccccc}
\hline \multirow{2}{*}{$\begin{array}{c}\text { Frequência } \\
\text { angular (rad/s) }\end{array}$} & \multicolumn{5}{c}{ teor de PPA (\%) } \\
\cline { 2 - 6 } & $\mathbf{0 , 0}$ & $\mathbf{0 , 5}$ & $\mathbf{1 , 0}$ & $\mathbf{1 , 5}$ & $\mathbf{2 , 0}$ \\
\hline $10^{-5}$ & $5,63.10^{0}$ & 1,7 & 3,6 & 25,1 & 167,5 \\
$10^{-4}$ & $5,64.10^{1}$ & 1,7 & 3,5 & 19,9 & 90,0 \\
$10^{-3}$ & $5,61.10^{2}$ & 1,7 & 3,0 & 12,3 & 40,7 \\
$10^{-2}$ & $5,10.10^{3}$ & 1,7 & 2,5 & 7,1 & 17,8 \\
$\mathbf{1 0}^{-1}$ & $\mathbf{4 , 2 7 . 1 0 ^ { 4 }}$ & $\mathbf{1 , 6}$ & $\mathbf{1 , 8}$ & $\mathbf{5 , 2}$ & $\mathbf{8 , 9}$ \\
$10^{0}$ & $2,97.10^{5}$ & 1,6 & 1,5 & 2,9 & 4,4 \\
$\mathbf{1 0}^{\mathbf{1}}$ & $\mathbf{1 , 7 9 . 1 0 ^ { 6 }}$ & $\mathbf{1 , 7}$ & $\mathbf{1 , 3}$ & $\mathbf{1 , 7}$ & $\mathbf{2 , 3}$ \\
$10^{2}$ & $8,55.10^{6}$ & 1,7 & 1,2 & 1,2 & 1,5 \\
$10^{3}$ & $2,85.10^{7}$ & 2,1 & 1,3 & 1,0 & 1,1 \\
$10^{4}$ & $7,61.10^{7}$ & 1,9 & 1,3 & 0,9 & 1,0 \\
\hline
\end{tabular}

No caso do REDUC, o aumento da rigidez é de, aproximadamente, 1,5 vezes para os teores entre 0,5 e $1,5 \%$ e 2,3 vezes para o teor de 2,0\% de PPA. Mais uma vez o efeito enrijecedor do PPA no LUBNOR é invertido nas frequências mais altas (temperaturas baixas), uma vez que os ligantes asfálticos modificados são menos rígidos que o LUBNOR puro.

A Tabela 4.10 apresenta as variações de $\mathrm{G}^{*}$ do LUBNOR modificado com os quatro teores de PPA, envelhecido a longo prazo, comparativamente ao LUBNOR puro, também envelhecido a longo prazo. A Tabela 4.11 apresenta o mesmo tipo de comparação para o REDUC. As análises foram feitas seguindo a mesma linha de raciocínio utilizada nas análises anteriores.

$\mathrm{Na}$ frequência de $0,1 \mathrm{rad} / \mathrm{s}$, a adição de $0,5 \%$ no LUBNOR provoca um enrijecimento de aproximadamente 1,5 vezes e a adição de 1,0, 1,5 e 2,0\% de PPA no LUBNOR provoca um enrijecimento do ligante asfáltico de aproximadamente 2,3 vezes. Logo, em termos de envelhecimento a longo prazo, a adição de mais de 1,0\% no LUBNOR não é recomendada. No caso do REDUC, a adição de 0,5 e 1,0\% de PPA enrijece o ligante asfáltico em aproximadamente 1,5 e 2 vezes, respectivamente, a adição de 1,5\% de PPA enrijece o ligante 
asfáltico em aproximadamente 4 vezes e a adição de 2,0\% de PPA enrijece o ligante asfáltico em aproximadamente 6 vezes. Assim como nas condições virgem e na condição envelhecida a curto prazo, observa-se que o REDUC é mais sensível à adição de PPA, em termos de rigidez.

Tabela 4.10 - Variações dos valores de $\mathrm{G}^{*}$ para o LUBNOR puro e modificados com PPA, a $25^{\circ} \mathrm{C}$, envelhecido no PAV

\begin{tabular}{cccccc}
\hline \multirow{2}{*}{$\begin{array}{c}\text { Frequência } \\
\text { angular }(\mathbf{r a d} / \mathbf{s})\end{array}$} & $\mathbf{0 , 0}$ & $\mathbf{0 , 5}$ & $\mathbf{1 , 0}$ & $\mathbf{1 , 5}$ & $\mathbf{2 , 0}$ \\
\cline { 2 - 6 } & $4,4.10^{2}$ & 4,0 & 16,1 & 33,8 & 45,8 \\
$10^{-5}$ & $3,4.10^{3}$ & 2,9 & 7,8 & 12,8 & 16,2 \\
$10^{-4}$ & $2,1.10^{4}$ & 2,1 & 4,5 & 5,8 & 7,4 \\
$10^{-3}$ & $1,0.10^{5}$ & 1,6 & 3,1 & 3,2 & 4,0 \\
$10^{-2}$ & $\mathbf{4 , 2 . 1 0 ^ { 5 }}$ & $\mathbf{1 , 4}$ & $\mathbf{2 , 3}$ & $\mathbf{2 , 1}$ & $\mathbf{2 , 5}$ \\
$\mathbf{1 0}^{-1}$ & $1,5.10^{6}$ & 1,2 & 1,7 & 1,4 & 1,8 \\
$10^{0}$ & $\mathbf{5 , 5 . 1 0 ^ { 6 }}$ & $\mathbf{1 , 0}$ & $\mathbf{1 , 4}$ & $\mathbf{1 , 0}$ & $\mathbf{1 , 2}$ \\
$\mathbf{1 0}^{\mathbf{1}}$ & $1,6.10^{7}$ & 1,0 & 1,2 & 0,8 & 1,0 \\
$10^{2}$ & $3,9.10^{7}$ & 0,9 & 1,1 & 0,7 & 0,8 \\
$10^{3}$ & $8,4.10^{7}$ & 0,9 & 1,0 & 0,7 & 0,8 \\
$10^{4}$ & & & & & \\
\hline
\end{tabular}

Tabela 4.11 - Variações dos valores de $\mathrm{G}^{*}$ para o REDUC puro e modificados com PPA, a $25^{\circ} \mathrm{C}$, envelhecido no PAV

\begin{tabular}{cccccc}
\hline \multirow{2}{*}{$\begin{array}{c}\text { Frequência } \\
\text { angular }(\mathbf{r a d} / \mathbf{s})\end{array}$} & $\mathbf{0 , 0}$ & $\mathbf{0 , 5}$ & $\mathbf{1 , 0}$ & $\mathbf{1 , 5}$ & $\mathbf{2 , 0}$ \\
\cline { 2 - 6 } & $2,03.10^{1}$ & 1,5 & 4,1 & 36,5 & 153,6 \\
$10^{-5}$ & $1,97.10^{2}$ & 1,5 & 3,7 & 23,7 & 68,9 \\
$10^{-4}$ & $1,87.10^{3}$ & 1,5 & 2,9 & 11,9 & 26,5 \\
$10^{-3}$ & $1,49.10^{4}$ & 1,5 & 2,2 & 6,3 & 11,3 \\
$10^{-2}$ & $\mathbf{1 , 1 7 . 1 0}^{\mathbf{5}}$ & $\mathbf{1 , 5}$ & $\mathbf{1 , 9}$ & $\mathbf{4 , 2}$ & $\mathbf{5 , 6}$ \\
$\mathbf{1 0}^{-1}$ & $6,74.10^{5}$ & 1,6 & 1,6 & 2,5 & 2,9 \\
$10^{0}$ & $\mathbf{3 , 2 0 . 1 0}$ & $\mathbf{1 , 7}$ & $\mathbf{1 , 3}$ & $\mathbf{1 , 6}$ & $\mathbf{1 , 7}$ \\
$\mathbf{1 0}^{\mathbf{1}}$ & $1,25.10^{7}$ & 1,7 & 1,2 & 1,3 & 1,2 \\
$10^{2}$ & $3,58.10^{7}$ & 1,7 & 1,2 & 1,1 & 0,9 \\
$10^{3}$ & $8,64.10^{7}$ & 1,6 & 1,1 & 1,0 & 0,8 \\
$10^{4}$ & & & & & \\
\hline
\end{tabular}

$\mathrm{Na}$ frequência de $10 \mathrm{rad} / \mathrm{s}$, a adição de PPA no LUBNOR praticamente não provoca um enrijecimento expressivo do ligante asfáltico. No caso do REDUC, o aumento da rigidez é 
de, aproximadamente, 1,6 vezes para todos os teores de PPA. Assim como nas condições virgem e envelhecida a curto prazo, nas frequências mais altas (temperaturas baixas) o efeito enrijecedor do PPA no LUBNOR é invertido, uma vez que os ligantes asfálticos modificados são menos rígidos que o LUBNOR puro. Esse efeito invertido também ocorre com a adição de 2,0\% no REDUC nas frequências mais altas.

$\mathrm{Na}$ análise a seguir é feita uma avaliação do efeito do nível de envelhecimento (curto e longo prazos) sobre a rigidez dos ligantes asfálticos, em função da frequência de carregamento, para uma dada temperatura de referência, com base nos dados obtidos das curvas-mestre. O objetivo é avaliar como o envelhecimento influencia o efeito enrijecedor do PPA sobre os dois ligantes asfálticos em estudo. As Tabelas 4.12 e 4.13 apresentam as variações de $\mathrm{G}^{*}$ do LUBNOR e do REDUC envelhecidos, respectivamente, em comparação a seus correspondentes virgens, em função da frequência de carregamento, a $25^{\circ} \mathrm{C}$. A variação de $G^{*}$ é expressa em termos de quantas vezes $G^{*}$ aumentou ou diminuiu por conta do envelhecimento, em relação aos valores de rigidez do ligante asfáltico virgem. Valores acima de 1,0 indicam enrijecimento em relação ao ligante asfáltico virgem e valores inferiores a 1,0 indicam que o ligante asfáltico envelhecido é menos rígido que o virgem. Na linha "virgem" estão indicados os valores originais e nas linhas "RTFOT" e "PAV" estão as relações.

O efeito do envelhecimento se dilui com o aumento da frequência de carregamento, sendo necessário comparar as variações de $\mathrm{G}^{*}$ nas frequências mais baixas. Pode-se observar que os ligantes asfálticos são bem mais sensíveis ao envelhecimento a longo prazo. De acordo com a Tabela 4.12, em termos de envelhecimento a curto prazo, o LUBNOR $+0,5 \%$ de PPA é o mais sensível ao envelhecimento (em torno de 11,7 vezes a $10^{-4} \mathrm{rad} / \mathrm{s}$, por exemplo). $\mathrm{O}$ LUBNOR $+1,5 \%$ de PPA é o menos sensível ao envelhecimento (em torno de 2,8 vezes a $10^{-4}$ $\mathrm{rad} / \mathrm{s}$, por exemplo). O LUBNOR + 2,0\% é mais sensível ao envelhecimento do que o LUBNOR $+1,5 \%$, no entanto, é menos sensível ao envelhecimento do que o LUBNOR modificado com $1,0 \%$ de PPA ou menos. Na frequência de $10 \mathrm{rad} / \mathrm{s}$, no que se refere ao envelhecimento a curto prazo, não se observa efeito significativo do teor de PPA, sendo o envelhecimento a curto prazo responsável por provocar um enrijecimento médio de 2,0 vezes em relação à rigidez dos materiais virgens correspondentes. Já em relação ao envelhecimento a longo prazo, o LUBNOR + 1,0\% PPA é o mais sensível ao envelhecimento e o LUBNOR + 2,0\% PPA é o menos sensível. 
Tabela 4.12 - Variações dos valores de G* para o LUBNOR puro e modificados , a $25^{\circ} \mathrm{C}$, em função do envelhecimento

\begin{tabular}{|c|c|c|c|c|c|c|c|c|c|c|}
\hline & \multicolumn{10}{|c|}{ Frequência (rad/s) } \\
\hline & $10^{-5}$ & $10^{-4}$ & $10^{-3}$ & $10^{-2}$ & $10^{-1}$ & $\mathbf{1}$ & $10^{1}$ & $10^{2}$ & $10^{3}$ & $10^{4}$ \\
\hline & \multicolumn{10}{|c|}{ LUBNOR 0,0\% PPA } \\
\hline Virgem & $1,2.10^{1}$ & $1,1.10^{2}$ & $1,0.10^{3}$ & $8,9 \cdot 10^{3}$ & $6,0.10^{4}$ & $3,9.10^{5}$ & $1,9.10^{6}$ & $7,5 \cdot 10^{6}$ & $2,5 \cdot 10^{7}$ & $7,0.10^{7}$ \\
\hline RTFOT & 7,24 & 6,81 & 5,82 & 4,43 & 3,47 & 2,57 & 2,00 & 1,64 & 1,38 & 1,15 \\
\hline \multirow[t]{2}{*}{ PAV } & 37,92 & 30,06 & 19,2 & 11,37 & 6,99 & 3,93 & 2,95 & 2,11 & 1,56 & 1,21 \\
\hline & \multicolumn{10}{|c|}{ LUBNOR 0,5\% PPA } \\
\hline Virgem & $1,94.10^{1}$ & $1,9.10^{2}$ & $1,6.10^{3}$ & $1,1 \cdot 10^{4}$ & $6,3 \cdot 10^{4}$ & $3,3 \cdot 10^{5}$ & $1,5.10^{6}$ & $6,0.10^{6}$ & $2,0.10^{7}$ & $6,7 \cdot 10^{7}$ \\
\hline RTFOT & 15,42 & 11,77 & 7,77 & 5,12 & 3,6 & 2,47 & 1,94 & 1,48 & 1,32 & 0,94 \\
\hline \multirow[t]{2}{*}{ PAV } & 89,75 & 52,59 & 27,67 & 14,83 & 9,02 & 5,33 & 3,86 & 2,49 & 1,73 & 1,12 \\
\hline & \multicolumn{10}{|c|}{ LUBNOR 1,0\% PPA } \\
\hline Virgem & $4,20.10^{1}$ & $3,7.10^{2}$ & $2,7.10^{3}$ & $1,6.10^{4}$ & $7,9.10^{4}$ & $3,3 \cdot 10^{5}$ & $1,3.10^{6}$ & $4,8 \cdot 10^{6}$ & $1,6.10^{7}$ & $4,2 \cdot 10^{7}$ \\
\hline RTFOT & 14,69 & $\mathbf{9 , 8 5}$ & 6,27 & 4,34 & 3,31 & 2,72 & 2,3 & 1,90 & 1,61 & 1,47 \\
\hline \multirow[t]{2}{*}{ PAV } & 167,36 & 72,16 & 33,95 & 19,79 & 12,2 & 8,07 & 5,71 & 3,88 & 2,74 & 2,06 \\
\hline & \multicolumn{10}{|c|}{ LUBNOR 1,5\% PPA } \\
\hline Virgem & $9,79 \cdot 10^{1}$ & $7,8.10^{2}$ & $4,8 \cdot 10^{3}$ & $2,4.10^{4}$ & $1,1.10^{4}$ & $4,0.10^{5}$ & $1,4.10^{6}$ & $5,0.10^{6}$ & $1,9.10^{7}$ & $5,0.10^{7}$ \\
\hline RTFOT & 3,05 & 2,80 & 2,57 & 2,35 & 2,11 & 2,05 & 1,95 & 1,78 & 1,42 & 1,25 \\
\hline \multirow[t]{2}{*}{ PAV } & 150,49 & 55,58 & 25,36 & 13,58 & 8,30 & 5,50 & 3,66 & 2,48 & 1,54 & 1,21 \\
\hline & \multicolumn{10}{|c|}{ LUBNOR 2,0\% PPA } \\
\hline Virgem & $4,6.10^{2}$ & $2,9.10^{3}$ & $1,4.10^{4}$ & $6,5 \cdot 10^{4}$ & $2,4.10^{5}$ & $8,6.10^{5}$ & $2,8.10^{6}$ & $8,4 \cdot 10^{6}$ & $2,4.10^{7}$ & $5,8 \cdot 10^{7}$ \\
\hline RTFOT & 11,24 & 6,25 & 4,20 & 2,83 & 2,45 & 1,95 & 1,80 & 1,54 & 1,35 & 1,19 \\
\hline PAV & 43,57 & 19,33 & 11,17 & 6,08 & 4,42 & 3,20 & 2,42 & 1,77 & 1,36 & 1,12 \\
\hline
\end{tabular}

Não são verificadas tendências claras do efeito do teor de PPA em relação ao envelhecimento a curto prazo. Já em relação ao envelhecimento a longo prazo, o efeito do teor de PPA é mais bem definido: até o teor de 1,0\% de PPA, a adição de PPA provoca um aumento na sensibilidade ao envelhecimento. Para teores menores que 1,0\%, a adição de PPA aumenta a sensibilidade ao envelhecimento do ligante asfáltico da LUBNOR, enquanto para teores maiores que 1,0\%, a adição de PPA diminui a sensibilidade ao envelhecimento do ligante asfáltico da LUBNOR. Tal tendência se reproduz ao longo de todo o espectro de frequências.

A partir da Tabela 4.13, em termos de envelhecimento a curto prazo, observa-se, especialmente nas frequências baixas, que a adição de PPA provoca uma diminuição da sensibilidade ao envelhecimento até determinado ponto, depois disso, a adição de PPA volta a aumentar a sensibilidade do REDUC ao envelhecimento. Por exemplo, na frequência de $10^{-4}$ (frequência baixa, correspondente a tráfego lento), o REDUC puro envelhecido no RTFOT é 5,89 vezes mais rígido que o REDUC puro na condição virgem. O REDUC + 0,5\% PPA envelhecido no RTFOT é 3,25 vezes mais rígido que o REDUC + 0,5\% na condição virgem, 
logo, o REDUC + 0,5\% é menos sensível ao envelhecimento a curto prazo do que o REDUC puro. Já o REDUC + 1,5\% PPA envelhecido no RTFOT é 7,72 vezes mais rígido que o REDUC $+1,5 \%$ na condição virgem, ou seja, a adição de $1,5 \%$ aumenta a sensibilidade ao envelhecimento a curto prazo do ligante asfáltico. Já para frequências mais altas (10 rad/s), o REDUC puro é o mais sensível ao envelhecimento, sendo nítido o efeito do PPA em reduzir a sensibilidade ao envelhecimento a curto prazo, não sendo notada uma tendência clara quanto ao efeito do teor de PPA.

Em termos de sensibilidade ao envelhecimento a longo prazo, é observada a mesma tendência nas frequências baixas, ou seja, ocorre redução da sensibilidade ao envelhecimento nos teores inferiores a 1,0\% de PPA e aumento da sensibilidade ao envelhecimento nos teores superiores a 1,0\% de PPA. Na frequência de $10 \mathrm{rad} / \mathrm{s}$, o REDUC puro é o mais sensível ao envelhecimento, sendo nítido o efeito do PPA em reduzir a sensibilidade ao envelhecimento a longo prazo, não sendo notada uma tendência clara quanto ao efeito do teor de PPA.

Tabela 4.13 - Variações dos valores de $\mathrm{G}^{*}$ para o REDUC puro e modificados , a $25^{\circ} \mathrm{C}$, em função do envelhecimento

\begin{tabular}{|c|c|c|c|c|c|c|c|c|c|c|}
\hline & \multicolumn{10}{|c|}{ Frequência (rad/s) } \\
\hline & $10^{-5}$ & $10^{-4}$ & $10^{-3}$ & $10^{-2}$ & $10^{-1}$ & 1 & $10^{1}$ & $10^{2}$ & $10^{3}$ & $10^{4}$ \\
\hline & \multicolumn{10}{|c|}{ REDUC 0,0\% PPA } \\
\hline Virgem & $9,8.10^{-1}$ & 9,6 & $9,6.10^{1}$ & $9,8 \cdot 10^{2}$ & $8,1.10^{3}$ & $7,0.10^{4}$ & $5,4.10^{5}$ & $3,5.10^{6}$ & $2,1.10^{7}$ & $6,6.10^{7}$ \\
\hline RTFOT & 5,77 & 5,89 & 5,13 & 5,23 & 5,30 & 4,22 & 3,31 & 2,44 & 1,35 & 1,16 \\
\hline \multirow[t]{2}{*}{ PAV } & 20,76 & 20,57 & 19,41 & 15,33 & 14,50 & 9,57 & 5,93 & 3,56 & 1,70 & 1,31 \\
\hline & \multicolumn{10}{|c|}{ REDUC 0,5\% PPA } \\
\hline Virgem & $2,9.10^{0}$ & $3,0.10^{1}$ & $3,1.10^{2}$ & $2,9.10^{3}$ & $2,6.10^{4}$ & $2,0.10^{5}$ & $1,5.10^{6}$ & $8,4 \cdot 10^{6}$ & $3,6.10^{7}$ & $9,8.10^{7}$ \\
\hline RTFOT & 3,34 & 3,25 & 3,08 & 3,00 & 2,70 & 2,39 & 2,05 & 1,73 & 1,62 & 1,50 \\
\hline \multirow[t]{2}{*}{ PAV } & 10,29 & 9,81 & 8,96 & 7,66 & 6,81 & 5,29 & 3,70 & 2,56 & 1,69 & 1,40 \\
\hline & \multicolumn{10}{|c|}{ REDUC 1,0\% PPA } \\
\hline Virgem & $5,5 \cdot 10^{0}$ & $5,7.10^{1}$ & $5,5.10^{2}$ & $4,7.10^{3}$ & $3,5.10^{4}$ & $2,3.10^{5}$ & $1,4.10^{6}$ & $6,6.10^{6}$ & $2,8.10^{7}$ & $7,5 \cdot 10^{7}$ \\
\hline RTFOT & 3,71 & 3,43 & 3,12 & 2,70 & 2,24 & 1,93 & 1,70 & 1,49 & 1,34 & 1,31 \\
\hline \multirow[t]{2}{*}{ PAV } & 15,20 & 12,96 & 9,93 & 7,01 & 6,50 & 4,59 & 3,18 & 2,33 & 1,47 & 1,32 \\
\hline & \multicolumn{10}{|c|}{ REDUC $1,5 \%$ PPA } \\
\hline Virgem & $1,6.10^{1}$ & $1,5.10^{2}$ & $1,2 \cdot 10^{3}$ & $6,7 \cdot 10^{3}$ & $3,8.10^{4}$ & $2,2.10^{5}$ & $1,1.10^{6}$ & $5,0.10^{6}$ & $2,2.10^{7}$ & $6,5 \cdot 10^{7}$ \\
\hline RTFOT & 9,03 & 7,72 & 5,99 & 5,44 & 5,87 & 4,01 & 2,85 & 2,09 & 1,25 & 1,04 \\
\hline \multirow[t]{2}{*}{ PAV } & 47,26 & 32,08 & 19,21 & 14,13 & 13,18 & 7,86 & 4,81 & 3,14 & 1,70 & 1,29 \\
\hline & \multicolumn{10}{|c|}{ REDUC $2,0 \%$ PPA } \\
\hline Virgem & $5,1.10^{1}$ & $4,5.10^{2}$ & $3,2 \cdot 10^{3}$ & $1,8.10^{4}$ & $8,9.10^{4}$ & $3,9.10^{5}$ & $1,6.10^{6}$ & $6,4 \cdot 10^{6}$ & $2,4.10^{7}$ & $6,4 \cdot 10^{7}$ \\
\hline RTFOT & 18,54 & 11,41 & 7,20 & 5,12 & 4,26 & 3,35 & 2,53 & 1,96 & 1,34 & 1,15 \\
\hline PAV & 61,17 & 30,51 & 15,63 & 9,49 & 7,40 & 4,97 & 3,28 & 2,26 & 1,37 & 1,10 \\
\hline
\end{tabular}


A Tabela 4.14 apresenta as variações de $\mathrm{G}^{*} / \operatorname{sen} \delta$ do LUBNOR e do REDUC puros e modificados com os quatro teores de PPA, a $10 \mathrm{rad} / \mathrm{s}$ (frequência alta, correspondente a tráfego rápido), comparativamente ao respectivo ligante asfáltico de base puro. A partir destes resultados é feita uma análise do teor de PPA e do efeito da temperatura no parâmetro de deformação permanente da especificação Superpave $\left(\mathrm{G}^{*} / \mathrm{sen} \delta\right)$. Os resultados apresentados são apenas das amostras envelhecidas a curto prazo, nas temperaturas altas (temperaturas de ocorrência de deformação permanente).

A variação no parâmetro $\mathrm{G}^{*} / \mathrm{sen} \delta$ é expressa em termos de quantas vezes este parâmetro aumentou ou diminuiu por conta da adição de PPA, em função da temperatura. Valores acima de 1,0 indicam um aumento no parâmetro de deformação permanente em relação ao ligante asfáltico de base devido à adição de PPA e valores inferiores a 1,0 indicam uma diminuição no parâmetro $\mathrm{G} * / \operatorname{sen} \delta$. Na linha referente ao LUBNOR e ao REDUC estão indicados os valores originais do parâmetro $G^{*} / \operatorname{sen} \delta$ e nas linhas dos demais teores estão as relações.

De acordo com a Tabela 4.14, observa-se que o LUBNOR $+1,5 \%$ de PPA apresenta valores de $\mathrm{G}^{*} / \operatorname{sen} \delta$ maiores que os demais, logo, esta formulação seria a que mais contribuiria para a redução do acúmulo de deformação permanente da mistura asfáltica. Esse resultado vai de encontro ao resultado obtido com base nas propriedades do MSCR que serão apresentadas no próximo capítulo, onde o LUBNOR $+1,5 \%$ de PPA apresentou o menor valor de $\mathrm{J}_{\mathrm{nr}}$. Dessa forma, pode concluir que não é recomendada a adição de mais de 1,5\% de PPA no LUBNOR em termos de resistência à deformação permanente.

Observa-se que o REDUC $+1,5 \%$ de PPA apresenta valores do parâmetro $\mathrm{G}^{*} / \operatorname{sen} \delta$ maiores que os demais, sendo esta a formulação que mais contribuiria para a redução do acúmulo de deformação permanente da mistura asfáltica. Segundo a Tabela 4.14, a adição de 2,0\% de PPA ao REDUC torna o ligante asfáltico menos resistente à deformação permanente que o REDUC puro nas temperaturas mais baixas $\left(52\right.$ e $\left.64^{\circ} \mathrm{C}\right)$. Neste caso, o resultado encontrado por meio do parâmetro de deformação permanente é o oposto do resultado encontrado no ensaio de MSCR, uma vez que a formulação REDUC $+2,0 \%$ de PPA apresentou o menor valor de compliância não-recuperável, o que se refletiria em um menor potencial a sofrer deformação permanente. Esse resultado reforça a suspeita de que o parâmetro $\mathrm{G}^{*} / \mathrm{sen} \delta$ não representa adequadamente a resistência à deformação permanente dos ligantes asfálticos modificados. 
Tabela 4.14 - Variações dos valores de G*/sen $\delta$ para o LUBNOR e o REDUC puros e modificados, a $10 \mathrm{rad} / \mathrm{s}$, envelhecidos no RTFOT, em função da temperatura

\begin{tabular}{ccccc}
\hline & \multicolumn{4}{c}{ Temperatura $\left({ }^{\circ} \mathbf{C}\right)$} \\
Amostra & $\mathbf{5 2}$ & $\mathbf{6 4}$ & $\mathbf{7 6}$ & $\mathbf{8 2}$ \\
\hline LUBNOR & $6,4.10^{1}$ & $1,2.10^{1}$ & $2,6.10^{0}$ & $6,4.10^{-1}$ \\
LUBNOR + 0,5\% PPA & 2,3 & 3,0 & 3,6 & 3,7 \\
LUBNOR + 1,0\% PPA & 2,1 & 3,2 & 4,0 & 5,0 \\
LUBNOR + 1,5\% PPA & 6,0 & 10,4 & 17,5 & 25,5 \\
LUBNOR + 2,0\% PPA & 4,3 & 7,7 & 12,8 & 19,9 \\
REDUC & $1,8.10^{1}$ & $2,9.10^{0}$ & $6,1.10^{-1}$ & $1,5.10^{-1}$ \\
REDUC + 0,5\% PPA & 1,9 & 1,8 & 1,8 & 1,9 \\
REDUC + 1,0\% PPA & 2,4 & 2,7 & 2,8 & 2,9 \\
REDUC + 1,5\% PPA & 4,4 & 5,8 & 6,7 & 6,7 \\
REDUC + 2,0\% PPA & 0,8 & 0,8 & 1,3 & 2,4 \\
\hline
\end{tabular}

A Tabela 4.15 apresenta as variações de $\mathrm{G}^{*} \cdot \operatorname{sen} \delta$ do LUBNOR e do REDUC puros e modificados com os quatro teores de PPA, a $10 \mathrm{rad} / \mathrm{s}$, comparativamente ao respectivo ligante asfáltico de base puro. A partir destes resultados é feita uma análise do teor de PPA e do efeito da temperatura no parâmetro de fadiga da especificação Superpave $\left(\mathrm{G}^{*}\right.$.sen $\left.\delta\right)$. Os resultados apresentados são apenas das amostras envelhecidos a longo prazo (previamente envelhecidas no RTFOT) e nas temperaturas intermediárias (temperaturas de ocorrência trincas por fadiga).

Tabela 4.15 - Variações dos valores de G*.sen $\delta$ para o LUBNOR e o REDUC puros e modificados, a $10 \mathrm{rad} / \mathrm{s}$, envelhecidos no PAV, em função da temperatura

\begin{tabular}{ccccc}
\hline & \multicolumn{4}{c}{ Temperatura $\left({ }^{\circ} \mathbf{C}\right)$} \\
Amostra & $\mathbf{4}$ & $\mathbf{1 6}$ & $\mathbf{2 8}$ & $\mathbf{4 0}$ \\
\hline LUBNOR & $3,1.10^{4}$ & $9,5.10^{3}$ & $2,4.10^{3}$ & $5,5.10^{2}$ \\
LUBNOR + 0,5\% PPA & 0,9 & 0,9 & 1,0 & 1,1 \\
LUBNOR + 1,0\% PPA & 1,0 & 1,0 & 1,3 & 1,7 \\
LUBNOR + 1,5\% PPA & 0,9 & 1,0 & 1,2 & 1,8 \\
LUBNOR + 2,0\% PPA & 0,8 & 0,9 & 1,2 & 1,7 \\
REDUC & $5,2.10^{4}$ & $1,5.10^{4}$ & $2,7.10^{3}$ & $3,5.10^{2}$ \\
REDUC + 0,5\% PPA & 1,4 & 1,6 & 1,7 & 1,8 \\
REDUC + 1,0\% PPA & 1,1 & 1,1 & 1,3 & 1,7 \\
REDUC + 1,5\% PPA & 0,9 & 1,0 & 1,3 & 2,4 \\
REDUC + 2,0\% PPA & 0,8 & 0,8 & 1,3 & 2,4 \\
\hline
\end{tabular}


A variação no parâmetro $G^{*}$.sen $\delta$ é expressa em termos de quantas vezes o parâmetro $G^{*}$.sen $\delta$ aumentou ou diminuiu por conta da adição de PPA, em função da temperatura. Valores acima de 1,0 indicam um aumento no parâmetro de fadiga em relação ao ligante asfáltico de base devido à adição de PPA e valores inferiores a 1,0 indicam uma diminuição no parâmetro $\mathrm{G}^{*} \cdot \operatorname{sen} \delta$. Na linha referente ao LUBNOR e ao REDUC estão indicados os valores originais do parâmetro $\mathrm{G}^{*}$.sen $\delta$ e nas linhas dos demais teores estão as relações.

Observa-se que a adição de PPA provoca uma ligeira redução de rigidez do LUBNOR, nas temperaturas de 4 e $16^{\circ} \mathrm{C}$, e do REDUC, também a 4 e $16^{\circ} \mathrm{C}$, porém apenas nos teores de 1,5 e 2,0\%. O PPA aumenta a rigidez do LUBNOR e do REDUC nas temperaturas de 28 e $40^{\circ} \mathrm{C}$, além de aumentar a rigidez do REDUC nas temperaturas de 4 e $16^{\circ} \mathrm{C}$ quando são empregados os teores de 0,5 e 1,0\% de PPA. Partindo da lógica da especificação Superpave, de que ligantes asfálticos mais moles são mais indicados para fadiga por deformação controlada, o PPA contribuiria com o aumento da resistência à fadiga da mistura asfáltica apenas nas temperaturas mais baixas $\left(4\right.$ e $\left.16^{\circ} \mathrm{C}\right)$ e se usado em teores altos, no caso do $\operatorname{REDUC}(1,5$ e 2,0\%), e em qualquer teor para o LUBNOR (entre 0,5 e 2,0\%). Estes resultados não concordam com os obtidos do ensaio LAS, no qual se verificou que a adição de PPA seria benéfica à resistência à fadiga nas temperaturas de 25 e $35^{\circ} \mathrm{C}$. 


\section{CAPÍtUlo 5. ENSAIO DE FLUÊNCIA E RECUPERAÇÃo SOB TENSÕES MÚLTIPLAS (MSCR)}

Neste capítulo é feita um detalhamento acerca do ensaio de fluência e recuperação (MSCR), apresentação do novo critério de resistência dos ligantes asfálticos à deformação permanente e suas principais vantagens em relação ao ensaio da especificação Superpave utilizado anteriormente para caracterizar o desempenho de ligantes asfálticos em relação à deformação permanente. Neste capítulo também são apresentados os resultados obtidos através do ensaio de MSCR: (i) percentual de recuperação (\%R), utilizado para fornecer uma indicação da resposta elástica retardada do ligante asfáltico; (ii) compliância não-recuperável $\left(\mathrm{J}_{\mathrm{nr}}\right)$, utilizado para avaliar o potencial do ligante asfáltico a sofrer deformação permanente e (iii) o parâmetro $\mathrm{J}_{\mathrm{nr}, \text { diff, }}$ utilizado para avaliar a sensibilidade dos ligantes asfálticos a mudanças no nível de tensão. Os ensaios de MSCR foram rodados apenas nas temperaturas altas, uma vez que o objetivo do ensaio é avaliar o potencial à deformação permanente dos ligantes asfálticos.

\subsection{MSCR}

Na especificação Superpave, o parâmetro $G^{*} / \operatorname{sen} \delta$ é utilizado para caracterizar a resistência dos ligantes asfálticos à deformação permanente. O reômetro de cisalhamento dinâmico (DSR) é utilizado para aplicar carregamentos em regime oscilatório em uma amostra de ligante asfáltico e, desta maneira, o módulo complexo $\left(\mathrm{G}^{*}\right)$ e o ângulo de fase $(\delta)$ do material são obtidos. Embora este parâmetro represente adequadamente a resistência dos ligantes asfálticos não-modificados à deformação permanente, pesquisas têm mostrado que o mesmo não ocorre com os ligantes asfálticos modificados e, assim, alternativas foram propostas em estudos como os de Bahia et al., (2001), Bouldin et al., (2001) e Shenoy (2001) a fim de caracterizar, de maneira mais adequada, a resistência dos ligantes asfálticos modificados à deformação permanente.

Dentre as alternativas sugeridas pelos pesquisadores, Bahia et al., (2001) propuseram a substituição do ensaio de regime oscilatório da especificação Superpave por um ensaio de fluência repetida e recuperação (RCRT). Neste ensaio, uma amostra de ligante asfáltico é submetida a uma carga de $300 \mathrm{~Pa}$ por $1 \mathrm{~s}$ seguido de $9 \mathrm{~s}$ de recuperação, em um total de 100 ciclos, no DSR. A fim de avaliar a dependência do ligante asfáltico à tensão aplicada, a 
FHWA aperfeiçoou o RCRT por meio da inserção de níveis crescentes de tensão durante o ensaio, dando-lhe em seguida o nome de ensaio de fluência e recuperação sob tensão múltipla (MSCR).

O MSCR é realizado utilizando um reômetro de cisalhamento dinâmico, com geometria de placas paralelas de $25 \mathrm{~mm}$ de diâmetro, com distância entre placas de $1 \mathrm{~mm}$, na temperatura determinada pelo grau de desempenho do ligante asfáltico. O ensaio é feito a tensão controlada de acordo com a norma ASTM D7405-08, na qual a amostra é submetida a tensão constante durante 1 segundo seguido de repouso sob tensão nula por 9 segundos. $\mathrm{O}$ protocolo ASTM especifica que dez ciclos de fluência e recuperação sejam aplicados, sem intervalos entre eles, apenas na temperatura do PG do ligante asfáltico, porém, neste trabalho, os ensaios foram realizados nas temperaturas de 52, 58, 64, 70, 76, 82 e $88^{\circ} \mathrm{C}$. Nos dez primeiros ciclos de carregamento é aplicada a tensão de $0,1 \mathrm{kPa}$ e nos dez ciclos seguintes é aplicada a tensão de 3,2 kPa. Para cada ciclo de fluência e recuperação, são registradas as seguintes deformações:

- no início do período de fluência de cada ciclo $\left(\varepsilon_{0}\right)$, no tempo 0 segundo;

- no final do período de fluência de cada ciclo $\left(\varepsilon_{\mathrm{c}}\right)$, no tempo de 1 segundo; e

- no final do período de recuperação de cada ciclo $\left(\varepsilon_{\mathrm{r}}\right)$, no tempo de 10 segundos.

A partir destas medidas, duas propriedades são obtidas no MSCR: a compliância nãorecuperável $\left(\mathrm{J}_{\mathrm{nr}}\right)$ e o percentual de recuperação $(\% \mathrm{R})$. A compliância não-recuperável é calculada pela razão entre a deformação não-recuperável do ligante asfáltico e a tensão aplicada, de modo que as deformações do material passam a ser normalizadas pelo valor da tensão. O percentual de recuperação, por sua vez, é obtido pela razão entre a deformação recuperável e a deformação total do material, sendo expresso em porcentagem. O percentual de recuperação $(\% \mathrm{R})$ e a compliância não-recuperável $\left(\mathrm{J}_{\mathrm{nr}}\right)$ são calculadas por meio das equações 1 e 2 , respectivamente:

$$
\begin{aligned}
& \% R(\sigma, N)=\frac{\left[\left(\varepsilon_{c}-\varepsilon 0\right)-\left(\varepsilon_{r}-\varepsilon_{0}\right)\right] \times 100}{\left(\varepsilon_{c}-\varepsilon_{0}\right)} \\
& J_{n r}(\sigma, N)=\frac{\left(\varepsilon_{r}-\varepsilon_{c}\right)}{\sigma}
\end{aligned}
$$


Onde $\% \mathrm{R}(\sigma, \mathrm{N})$ é o percentual de recuperação e $\mathrm{J}_{\mathrm{nr}}(\sigma, \mathrm{N})$ é a compliância nãorecuperável na tensão $\sigma$ (para $\sigma=0,1 \mathrm{kPa}$ ou $3,2 \mathrm{kPa}$ ) para o n-ésimo ciclo de fluência e recuperação com $\mathrm{N}$ variando de 1 a 10. Para cada temperatura de ensaio, é obtida a média aritmética dos valore de $\% \mathrm{R}$ e $\mathrm{J}_{\mathrm{nr}}$ nos dez ciclos do ensaio, para cada tensão de cisalhamento.

Uma vez que $\mathrm{J}_{\mathrm{nr}}$ é o parâmetro para altas temperaturas obtido no ensaio MSCR, uma nova especificação foi desenvolvida (Tabela 5.1), baseada nos valores limites de $\mathrm{J}_{\mathrm{nr}}$ para diferentes níveis de carregamento de tráfego $(\mathrm{S}, \mathrm{H}, \mathrm{V}$ e E), respectivamente designados como padrão (Standard), pesado (Heavy), muito pesado (Very heavy) e extremamente pesado (Extremely heavy) (D’ANGELO, 2010).

A diferença percentual dos valores de $\mathrm{J}_{\mathrm{nr}}$ a 100 e $3.200 \mathrm{~Pa}\left(\mathrm{~J}_{\mathrm{nr}, \text { diff }}\right)$ não deve exceder $75 \%$, a fim de assegurar que o ligante asfáltico não seja excessivamente sensível à variação no nível de tensão (ANDERSON et al., 2010; ASPHALT INSTITUTE, 2010). Valores mínimos do percentual de recuperação também são recomendados e estão indicados na Tabela 5.2.

Tabela 5.1 - Classificação quanto ao valor de Jnr (AASHTO M320)

\begin{tabular}{|c|c|c|c|c|}
\hline $\begin{array}{l}\text { condição de } \\
\text { envelhecimento }\end{array}$ & propriedade & $\begin{array}{l}\text { limite máximo } \\
\qquad\left(\mathrm{kPa}^{-1}\right)\end{array}$ & nível de tráfego & $\begin{array}{l}\text { número de } \\
\text { solicitações }\end{array}$ \\
\hline & $\mathrm{J}_{\mathrm{nr}} \mathrm{a}$ & 4,0 & padrão (S) & $<10$ milhões \\
\hline envelhecido no & $3.200 \mathrm{~Pa}$ na & 2,0 & pesado $(\mathrm{H})$ & $>10$ milhões \\
\hline \multirow[t]{2}{*}{ RTFOT } & temperatura & 1,0 & muito pesado (V) & $>30$ milhões \\
\hline & do PG & 0,5 & extremamente pesado $(\mathrm{E})$ & $>100$ milhões \\
\hline
\end{tabular}

Tabela 5.2 - Valores de percentual de recuperação recomendado pelo FHWA (D’ANGELO, 2010)

\begin{tabular}{cc}
\hline $\mathrm{J}_{\mathrm{nr}}$ a $3.200 \mathrm{~Pa}\left(\mathrm{kPa}^{-1}\right)$ & \%R mínimo \\
\hline $1,01-2,0$ & 30 \\
$0,51-1,0$ & 35 \\
$0,251-0,50$ & 45 \\
$0,125-0,25$ & 50 \\
\hline
\end{tabular}




\subsection{ANÁLISE DE RESULTADOS}

Os resultados de recuperação elástica e compliância não-recuperável foram analisados de duas maneiras: (i) análise dos resultados na temperatura alta do PG de cada ligante asfáltico e (ii) análise dos resultados na temperatura do pavimento.

\subsubsection{Análise de resultados considerando o grau de desempenho do ligante asfáltico}

Um questionamento comum feito a respeito da adição do PPA inclui se o PPA tem o mesmo efeito em todos os tipos de ligante asfáltico. As propriedades do ensaio MSCR avaliadas aqui irão mostrar que isto não é verdade. As Figuras 5.1 e 5.2 apresentam os percentuais de recuperação dos ligantes asfálticos puros e modificados nos níveis de tensão de 100 e $3.200 \mathrm{~Pa}$, respectivamente. As Figuras 5.3 e 5.4 apresentam as compliâncias nãorecuperáveis dos ligantes asfálticos puros e modificados nos níveis de tensão de 100 e 3.200 $\mathrm{Pa}$, respectivamente.

\section{$\%$ R 100 Pa}

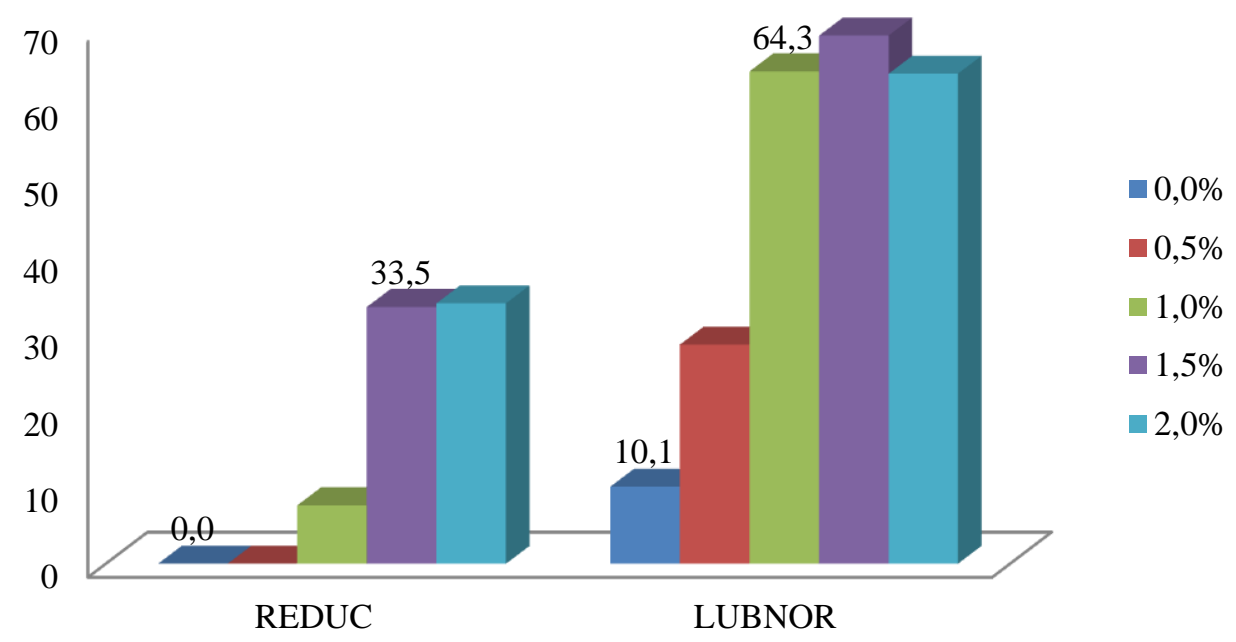

Figura 5.1 - Percentual de recuperação dos ligantes asfálticos puro e modificados, a 100Pa

A primeira impressão obtida dos resultados é de que o efeito da adição de PPA é bastante diferente para cada tipo de ligante asfáltico de base. É importante lembrar que as propriedades do MSCR foram obtidas na temperatura do PG de cada ligante asfáltico. Logo, 
as propriedades foram medidas a uma temperatura próxima à temperatura na qual os ligantes asfálticos apresentam a mesma rigidez.

\% R 3200

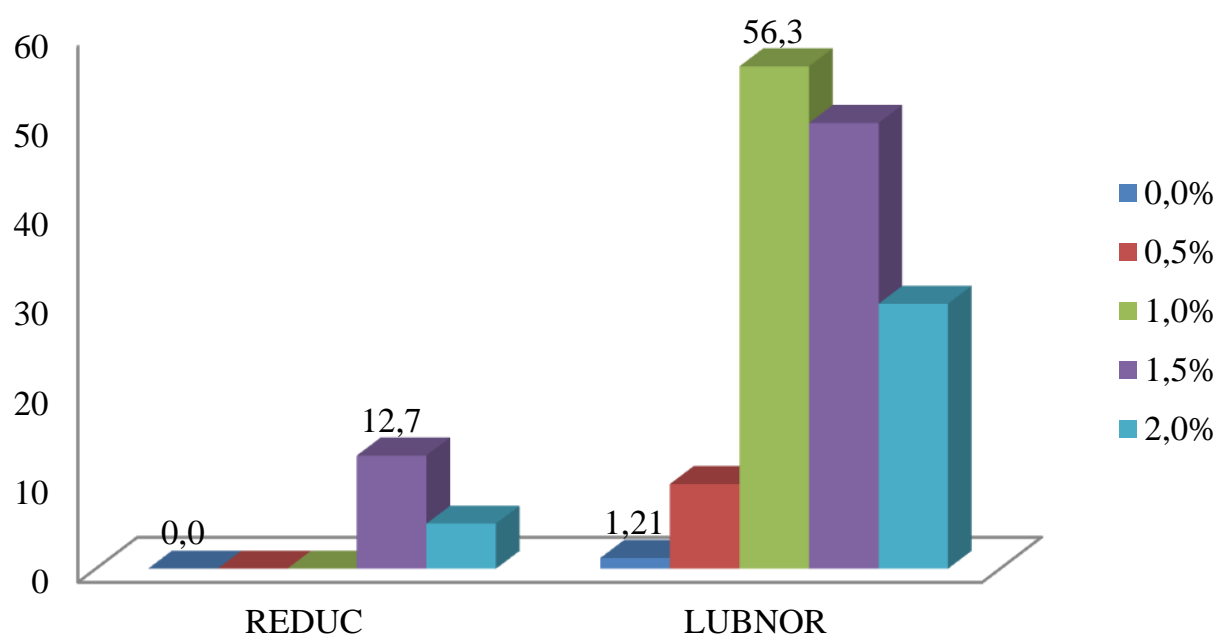

Figura 5.2 - Percentual de recuperação dos ligantes asfálticos puro e modificados, a 3.200Pa

A partir da combinação dos resultados do percentual de recuperação e da compliância não-recuperável, pode-se observar a existência de um teor ótimo de PPA para cada ligante asfáltico. O teor de PPA ótimo para o CAP da REDUC é 1,5\%, uma vez que, nesta proporção, o percentual de recuperação a $3.200 \mathrm{~Pa}$ foi o mais alto e os valores de compliância nãorecuperável nos níveis de tensão de 100 e 3.200 Pa foram os mais baixos. Embora os valores do percentual de recuperação do CAP da REDUC para as concentrações de 1,5 e 2,0\% sejam equivalentes no nível de tensão de $100 \mathrm{~Pa}$, o nível de tensão de 3.200 Pa é mais relevante para o desempenho deste material em relação à deformação permanente. Por esta razão, o resultado obtido a $3.200 \mathrm{~Pa}$ foi adotado como referência. $\mathrm{O}$ menor valor de $\mathrm{J}_{\mathrm{nr}}$ indica que o teor de PPA de $1,5 \%$ torna o CAP da REDUC mais resistente à deformação permanente do que as outras proporções de PPA.

Os teores ótimos de PPA obtidos para os ligantes asfálticos da LUBNOR e da REDUC são $1,0 \%$ e $1,5 \%$, respectivamente. O teor ótimo do CAP da LUBNOR foi obtido adotando o mesmo critério relacionado ao percentual de recuperação utilizado na obtenção do teor ótimo do CAP da REDUC, uma vez que o valor do percentual de recuperação a $100 \mathrm{~Pa}$ para o CAP 
da LUBNOR com 1,5\% de PPA é ligeiramente mais elevado do que o valor do percentual de recuperação do CAP da LUBNOR com 1,0\% de PPA.

O percentual de recuperação a $100 \mathrm{~Pa}$ do CAP puro da REDUC é de 0,0\%, mas a adição de 1,5\% de PPA aumenta este valor para aproximadamente 33\%. No mesmo nível de tensão, o valor do percentual de recuperação do CAP puro da LUBNOR é de $10,1 \%$ e a adição de 1,0\% de PPA aumenta em 6 vezes este valor. Para o nível de tensão de $3.200 \mathrm{~Pa}$, o CAP da LUBNOR é muito mais sensível à adição de PPA do que o ligante asfáltico da REDUC. Para o CAP da REDUC, a adição de 1,5\% de PPA aumenta em 13 vezes o percentual de recuperação em relação ao CAP puro da REDUC.

\section{Jnr 100Pa}

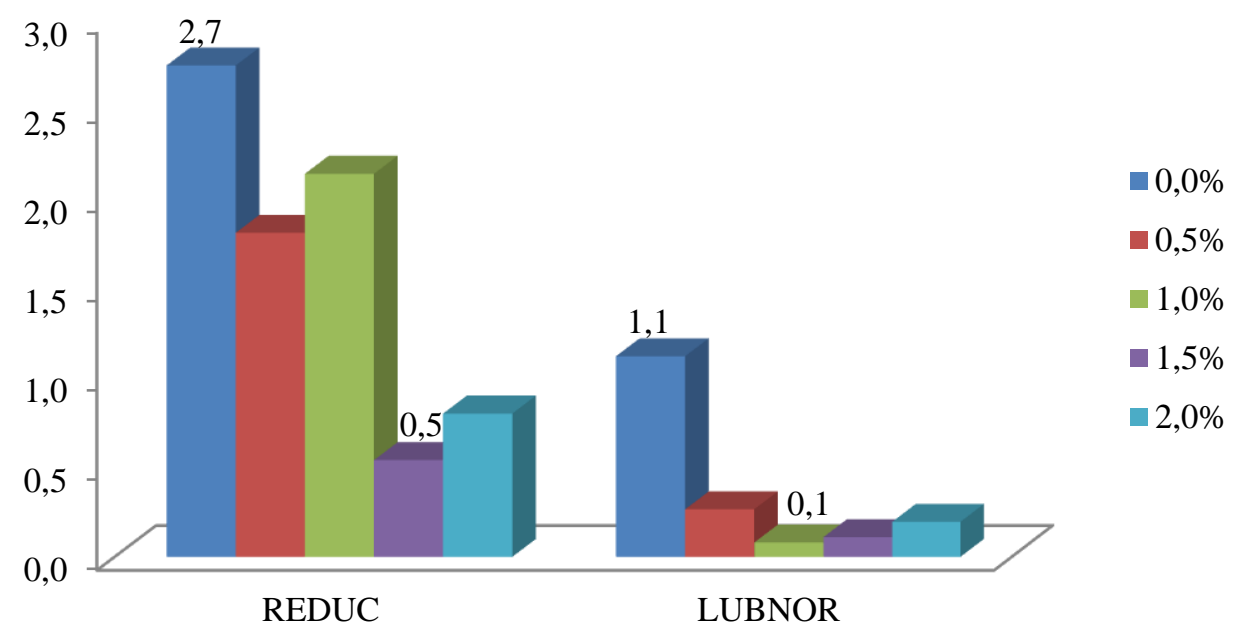

Figura 5.3 - Compliância não-recuperável dos ligantes asfálticos puro e modificados, a 100Pa

Para o CAP da LUBNOR, a adição do teor ótimo aumenta o percentual de recuperação de aproximadamente 47 vezes. Pode-se concluir que o CAP da LUBNOR é muito mais sensível à adição de PPA no nível de tensão mais elevado, uma vez que o CAP LUBNOR puro sofreu um maior aumento no percentual de recuperação a 3.200 Pa mesmo com um menor consumo de PPA.

Para o CAP da REDUC, a adição de 1,5\% de PPA diminuiu a compliância nãorecuperável em 5 e 4 vezes nos níveis de tensão de 100 e $3.200 \mathrm{~Pa}$, respectivamente, em relação ao CAP puro da REDUC. Para o CAP da LUBNOR, a adição do teor ótimo diminuiu o valor de $\mathrm{J}_{\mathrm{nr}}$ em 11 e 13 vezes nos níveis de tensão de 100 e $3.200 \mathrm{~Pa}$, respectivamente. Mais 
uma vez pode-se concluir que o CAP da LUBNOR é muito mais sensível à adição de PPA nos dois níveis de tensão que os outros dois ligantes asfálticos, uma vez que a adição do seu teor ótimo provocou um decréscimo mais expressivo de $\mathrm{J}_{\mathrm{nr}}$ mesmo com um menor consumo de PPA.

Jnr 3200Pa

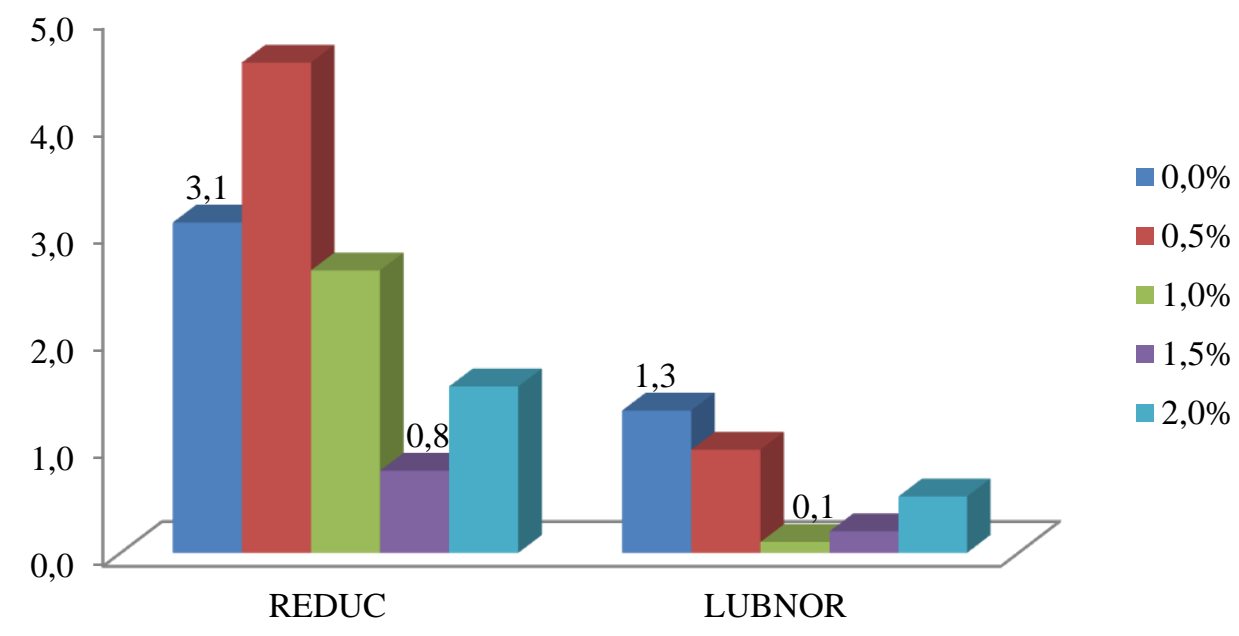

Figura 5.4 - Compliância não-recuperável dos ligantes asfálticos puro e modificados, a 3.200Pa

\subsubsection{Análise de resultados considerando a temperatura do pavimento}

\subsubsection{Percentual de recuperação}

As Figuras de 5.5 a 5.9 apresentam os valores de percentual de recuperação a $100 \mathrm{~Pa}$, nas temperaturas de 52, 58, 64, 70 e $76^{\circ} \mathrm{C}$, respectivamente, dos ligantes asfálticos da LUBNOR e da REDUC puros e modificados com PPA. As Figuras de 5.10 a 5.14 apresentam os valores de percentual de recuperação a $3.200 \mathrm{~Pa}$, nas temperaturas de 52, 58, 64, 70 e $76^{\circ} \mathrm{C}$, respectivamente, dos ligantes asfálticos da LUBNOR e da REDUC puros e modificados com PPA.

De maneira geral, observa-se que o percentual de recuperação dos ligantes asfálticos aumenta com a adição de PPA e diminui com o aumento da temperatura. O LUBNOR apresenta resultados mais altos de porcentagem de recuperação. No entanto, essa diferença entre os valores de \%R do LUBNOR e do REDUC diminui com o aumento da proporção de PPA, uma vez que o REDUC é mais sensível à adição de PPA conforme indicado nas Tabelas 
5.3 e 5.4. As formulações LUBNOR + 1,5\% PPA e LUBNOR + 2,0\% de PPA apresentaram valores de percentual de recuperação equivalentes em todas as temperaturas. Logo, em termos de percentual de recuperação, a adição de um teor maior que 1,5\% não é recomendada.

$\%$ R 100Pa, $5^{\circ} \mathrm{C}$

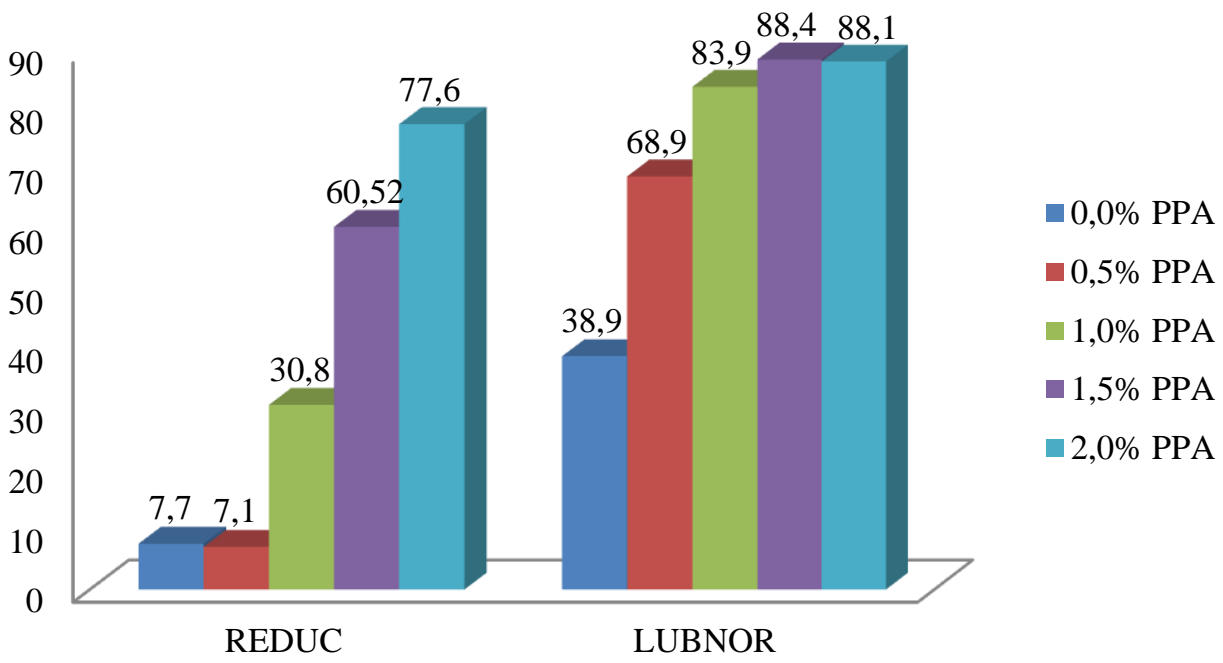

Figura 5.5 - Percentual de recuperação a $100 \mathrm{~Pa}$, a $52^{\circ} \mathrm{C}$

$\% \mathrm{R} 100 \mathrm{~Pa}, \mathbf{5 8}^{\circ} \mathrm{C}$

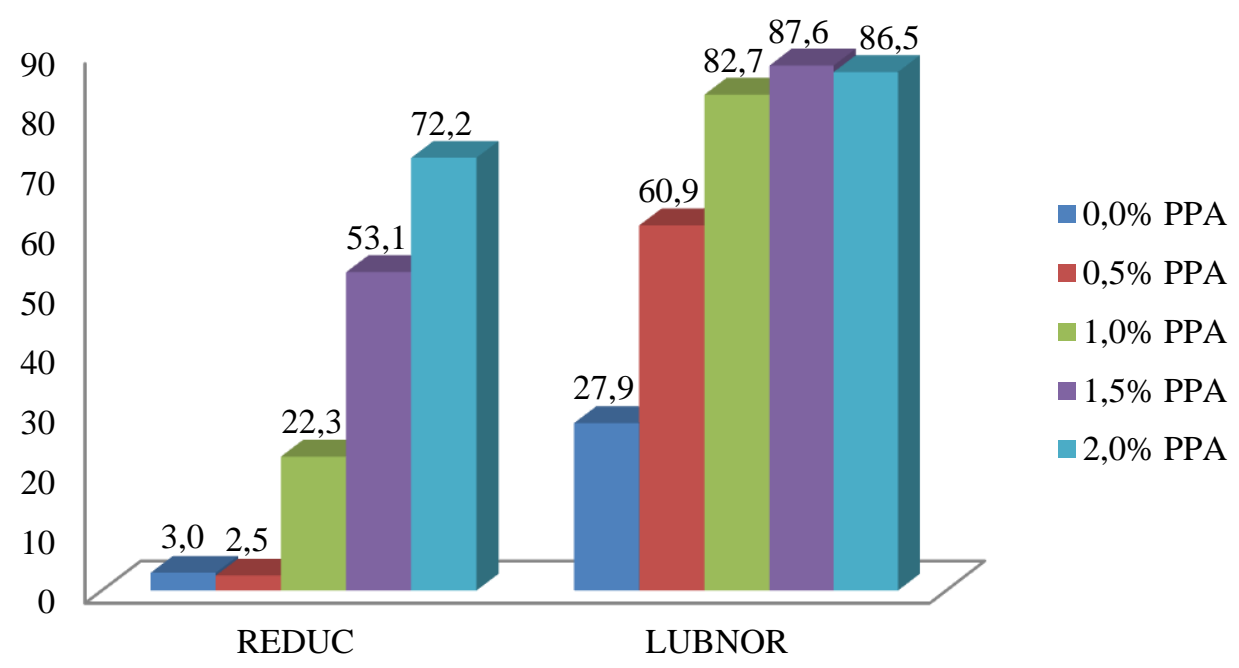

Figura 5.6 - Percentual de recuperação a $100 \mathrm{~Pa}$, a $58^{\circ} \mathrm{C}$ 
A Tabela 5.3 apresenta as variações do \%R, a $100 \mathrm{~Pa}$, do LUBNOR e do REDUC modificados com os quatro teores de PPA, na condição envelhecida a curto prazo, comparativamente ao ligante asfáltico de base puro, também na condição envelhecida a curto prazo.

$\% \mathrm{R} 100 \mathrm{~Pa}, 64^{\circ} \mathrm{C}$

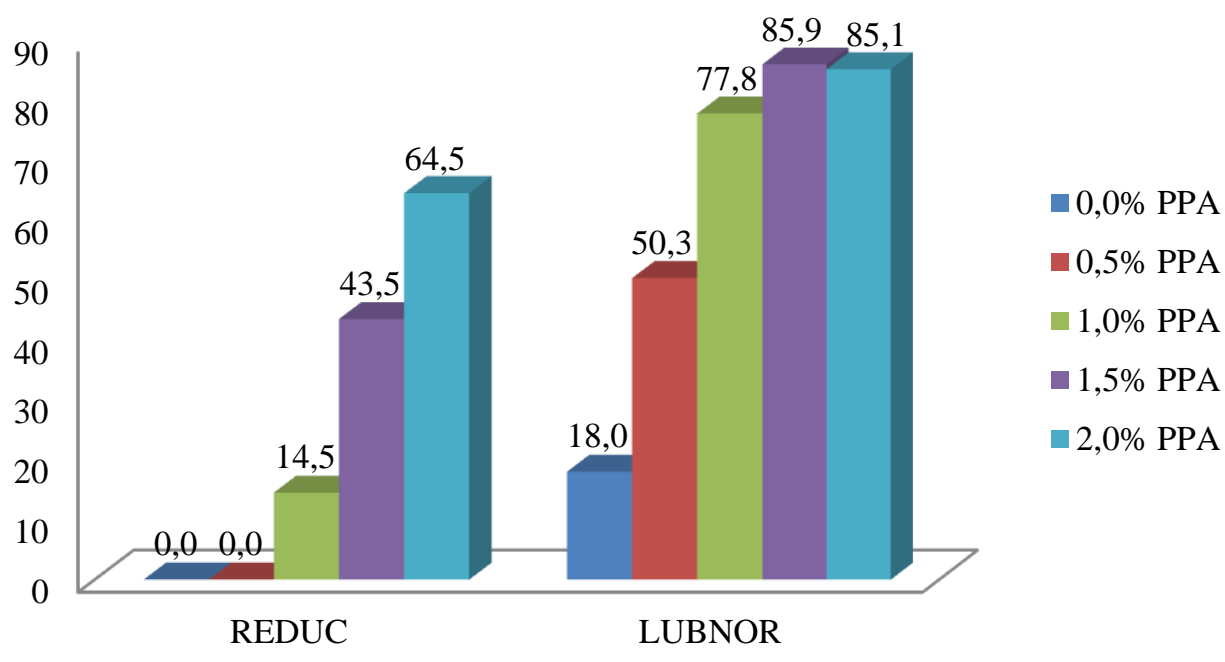

Figura 5.7 - Percentual de recuperação a $100 \mathrm{~Pa}$, a $64^{\circ} \mathrm{C}$

$\% \mathrm{R} 100 \mathrm{~Pa}, 70^{\circ} \mathrm{C}$

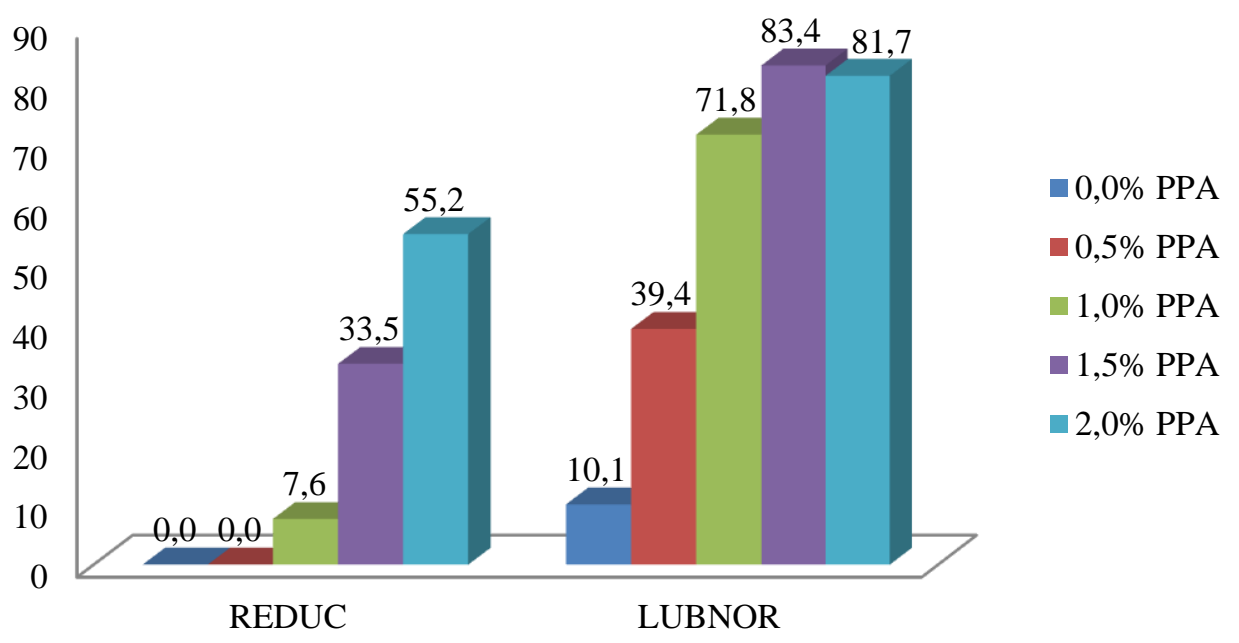

Figura 5.8 - Percentual de recuperação a $100 \mathrm{~Pa}$, a $70^{\circ} \mathrm{C}$

A Tabela 5.4 apresenta o mesmo tipo de comparação para os valores de $\% \mathrm{R}$ a 3.200 $\mathrm{Pa}$. A variação de $\% \mathrm{R}$ é expressa em termos de quantas vezes o \% $\mathrm{R}$ aumentou ou diminuiu 
por conta da adição de PPA, em função da temperatura, em relação aos valores de percentual de recuperação do ligante asfáltico de base. Valores acima de 1,0 indicam um aumento no \%R em relação ao ligante asfáltico de base e valores inferiores a 1,0 indicam que o ligante asfáltico modificado apresenta um percentual de recuperação menor que o ligante asfáltico de base. Os campos onde a variação não foi calculada são os campos onde o valor de $\% \mathrm{R}$ do ligante asfáltico de base é zero

$\% \mathrm{R} 100 \mathrm{~Pa}, 7^{\circ} \mathrm{C}$

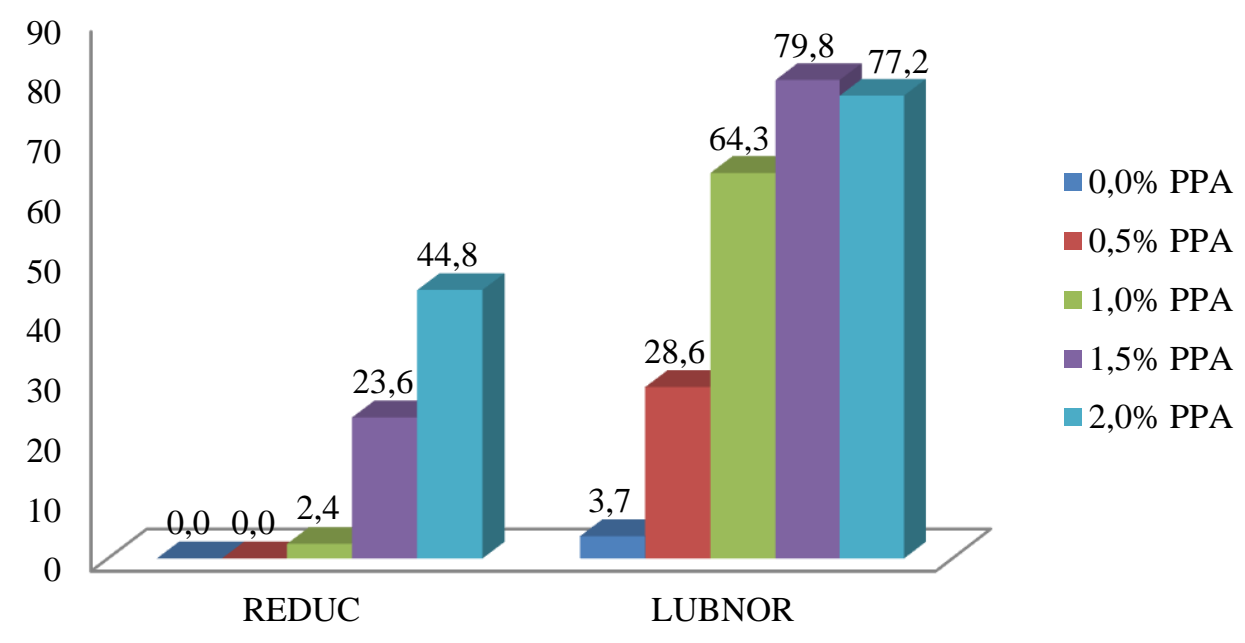

Figura 5.9 - Percentual de recuperação a $100 \mathrm{~Pa}$, a $76^{\circ} \mathrm{C}$

\% R 3200Pa, 52 $^{\circ} \mathrm{C}$

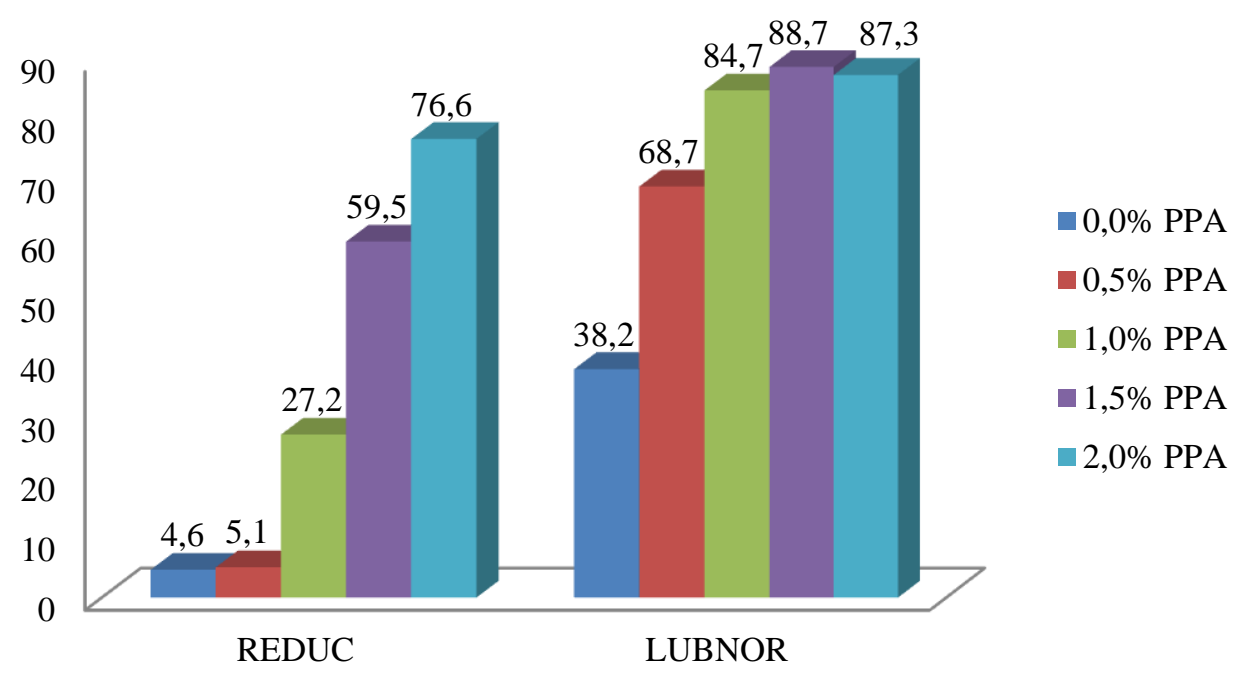

Figura 5.10 - Percentual de recuperação a $3.200 \mathrm{~Pa}$, a $52^{\circ} \mathrm{C}$ 
$\%$ R 3200Pa, $5^{\circ} \mathrm{C}$

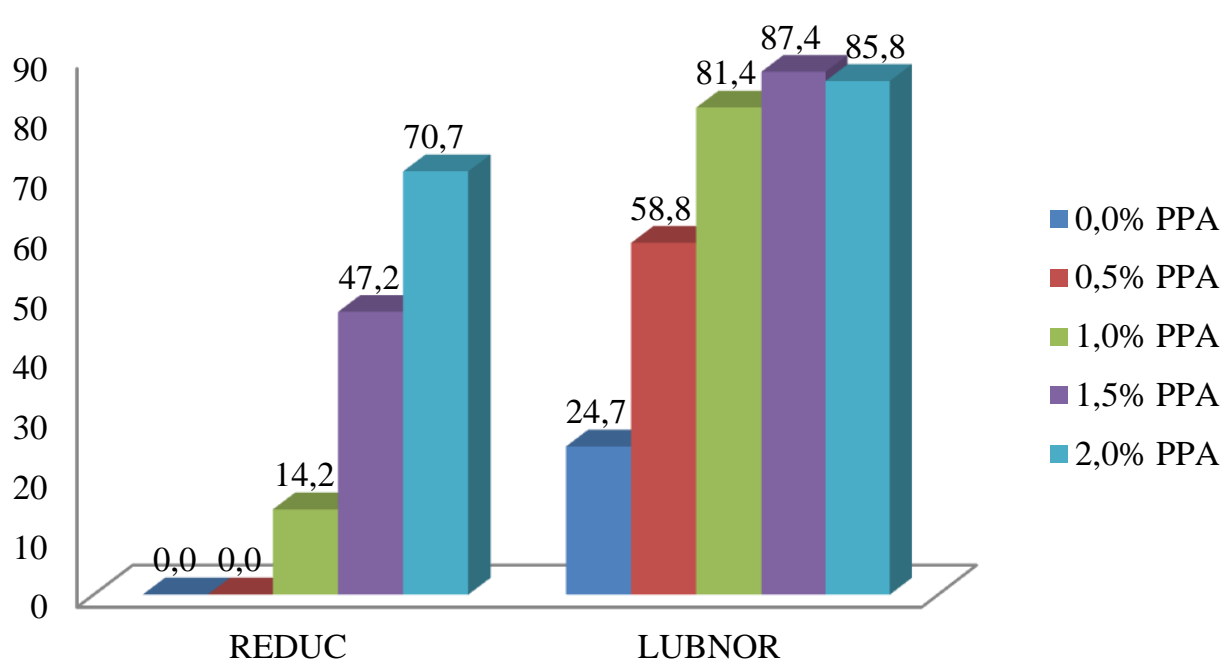

Figura 5.11- Percentual de recuperação a $3.200 \mathrm{~Pa}$, a $58^{\circ} \mathrm{C}$

$\% \mathrm{R} \mathrm{3200Pa}, 64^{\circ} \mathrm{C}$

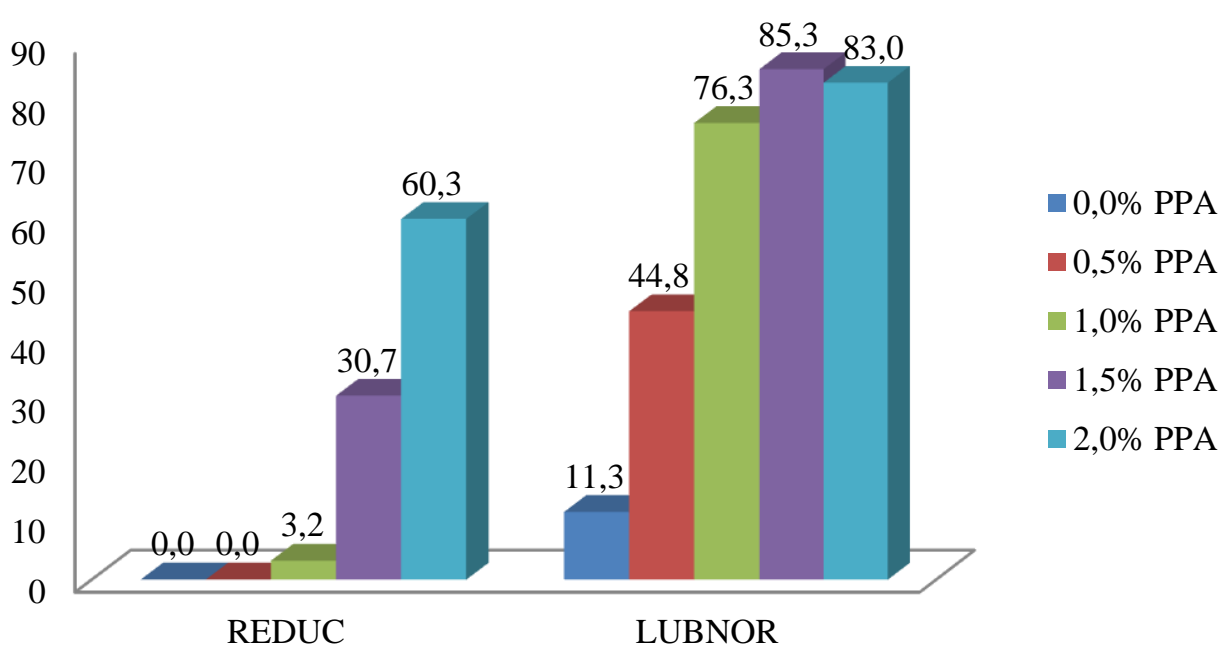

Figura 5.12 - Percentual de recuperação a $3.200 \mathrm{~Pa}$, a $64^{\circ} \mathrm{C}$

A Tabela 5.5 apresenta as proporções mínimas de PPA necessárias para obter o valor mínimo de recuperação elástica de $30 \%$ em cada temperatura. Para obter um mínimo de 30\% para o percentual de recuperação utilizando o ligante asfáltico da REDUC, a temperatura mais elevada seria $70^{\circ} \mathrm{C}$ e a proporção de PPA seria $1,95 \%$. Para temperaturas mais elevadas, proporções de PPA maiores que 2,00\% deveriam ser utilizadas para obter o valor mínimo de $30 \%$ para o percentual de recuperação. Utilizando o CAP da LUBNOR, a temperatura do pavimento mais elevada seria $88^{\circ} \mathrm{C}$ e a proporção de PPA seria $2,00 \%$. 
$\%$ R 3200Pa, $7^{\circ} \mathrm{C}$

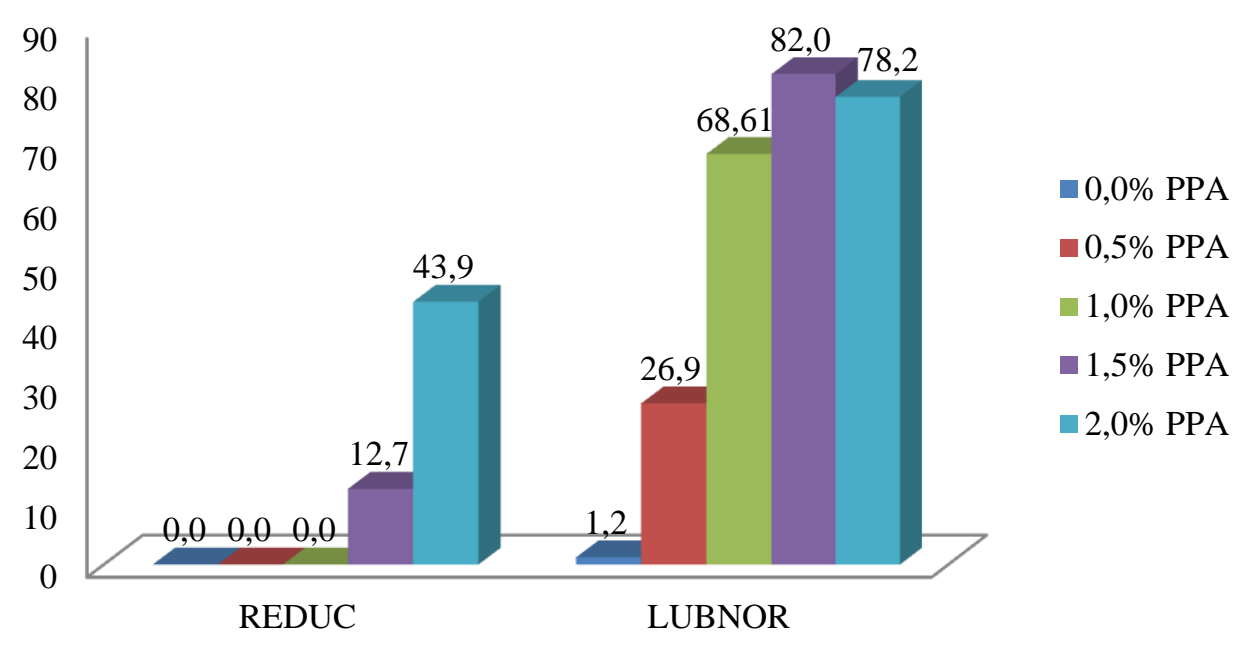

Figura 5.13 - Percentual de recuperação a $3.200 \mathrm{~Pa}$, a $70^{\circ} \mathrm{C}$

$\%$ R 3200Pa, $76^{\circ} \mathrm{C}$

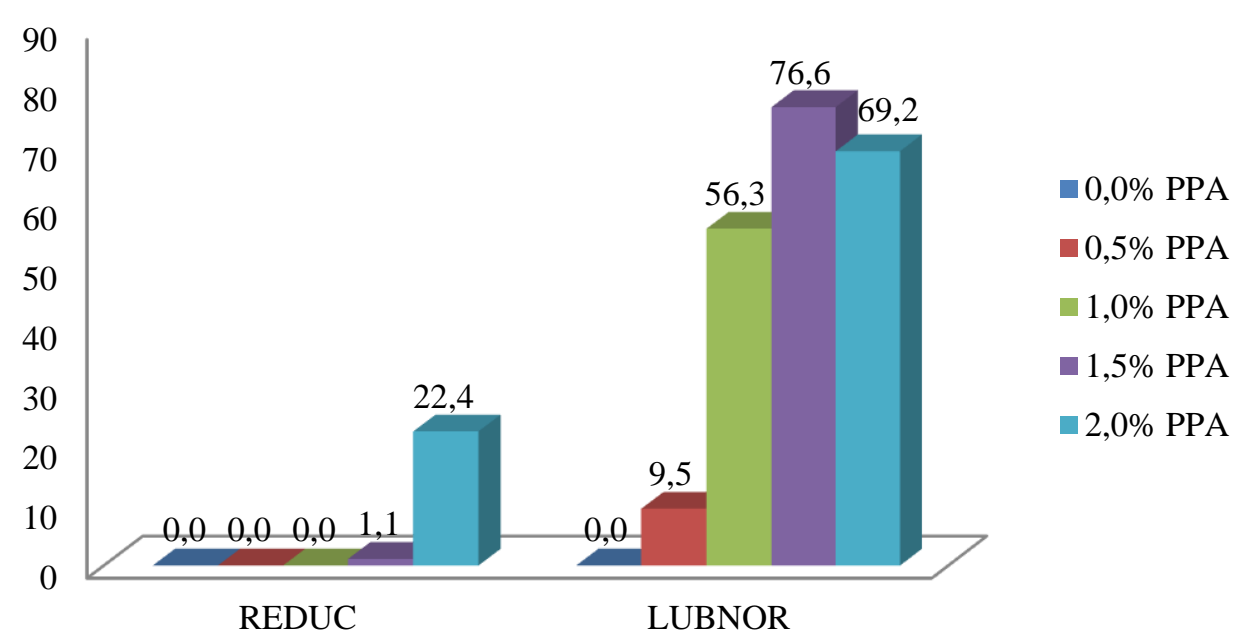

Figura 5.14 - Percentual de recuperação a $3.200 \mathrm{~Pa}$, a $76^{\circ} \mathrm{C}$

\subsubsection{Compliância não-recuperável}

As Figuras de 5.15 a 5.19 apresentam os valores de compliância não-recuperável a 100 $\mathrm{Pa}$, nas temperaturas de 52,58,64, 70 e $76^{\circ} \mathrm{C}$, respectivamente, dos ligantes asfálticos da LUBNOR e da REDUC puros e modificados com PPA. As Figuras de 5.20 a 5.24 apresentam os valores de compliância não-recuperável a $3.200 \mathrm{~Pa}$, nas temperaturas de 52, 58, 64, 70 e $76^{\circ} \mathrm{C}$, respectivamente, dos ligantes asfálticos da LUBNOR e da REDUC puros e modificados com PPA. 
Tabela 5.3 - Variações dos valores de \%R, a 100Pa, para o REDUC e LUBNOR em função da temperatura

\begin{tabular}{|c|c|c|c|c|c|}
\hline \multirow[b]{2}{*}{$\%$ PPA } & \multicolumn{5}{|c|}{ REDUC } \\
\hline & $52^{\circ} \mathrm{C}$ & $58^{\circ} \mathrm{C}$ & $64^{\circ} \mathrm{C}$ & $7^{\circ} \mathrm{C}$ & $7^{\circ} \mathrm{C}$ \\
\hline $\mathbf{0 , 0}$ & 1.0 & 1.0 & - & - & - \\
\hline 0,5 & 0.9 & 0.8 & - & - & - \\
\hline 1,0 & 4.0 & 7.5 & - & - & - \\
\hline 1,5 & 7.9 & 17.9 & - & - & - \\
\hline \multirow[t]{2}{*}{2,0} & 10.1 & 24.3 & - & - & - \\
\hline & \multicolumn{5}{|c|}{ LUBNOR } \\
\hline$\%$ PPA & $52^{\circ} \mathrm{C}$ & $58^{\circ} \mathrm{C}$ & $64^{\circ} \mathrm{C}$ & $7^{\circ} \mathrm{C}$ & $7^{\circ} \mathrm{C}$ \\
\hline $\mathbf{0 , 0}$ & 1.0 & 1.0 & 1.0 & 1.0 & 1.0 \\
\hline 0,5 & 1.8 & 2.2 & 2.8 & 3.9 & 7.7 \\
\hline 1,0 & 2.2 & 3.0 & 4.3 & 7.1 & 17.4 \\
\hline 1,5 & 2.3 & 3.1 & 4.8 & 8.3 & 21.6 \\
\hline 2,0 & 2.3 & 3.1 & 4.7 & 8.1 & 20.9 \\
\hline
\end{tabular}

Tabela 5.4 - Variações dos valores de \%R, a 3.200Pa, para o REDUC e LUBNOR em função da temperatura

\begin{tabular}{|c|c|c|c|c|c|}
\hline \multirow[b]{2}{*}{$\%$ PPA } & \multicolumn{5}{|c|}{ REDUC } \\
\hline & $52^{\circ} \mathrm{C}$ & $58^{\circ} \mathrm{C}$ & $64^{\circ} \mathrm{C}$ & $7^{\circ} \mathrm{C}$ & ${ }^{76^{\circ}} \mathrm{C}$ \\
\hline $\mathbf{0 , 0}$ & 1,0 & - & - & - & - \\
\hline 0,5 & 1,1 & - & - & - & - \\
\hline 1,0 & 5,9 & - & - & - & - \\
\hline 1,5 & 12,8 & - & - & - & - \\
\hline \multirow[t]{2}{*}{2,0} & 16,5 & - & - & - & - \\
\hline & \multicolumn{5}{|c|}{ LUBNOR } \\
\hline$\%$ PPA & $52^{\circ} \mathrm{C}$ & $58^{\circ} \mathrm{C}$ & $64^{\circ} \mathrm{C}$ & ${ }^{70}{ }^{\circ} \mathrm{C}$ & $7^{\circ} \mathrm{C}$ \\
\hline $\mathbf{0 , 0}$ & 1,0 & 1,0 & 1,0 & 1,0 & - \\
\hline 0,5 & 1,8 & 2,4 & 4,0 & 22,2 & 9,5 \\
\hline 1,0 & 2,2 & 3,3 & 6,8 & 56,7 & 56,3 \\
\hline 1,5 & 2,3 & 3,5 & 7,6 & 67,7 & 76,6 \\
\hline 2,0 & 2,3 & 3,5 & 7,4 & 64,6 & 69,2 \\
\hline
\end{tabular}

Tabela 5.5 - Teores mínimos de PPA para obter a recuperação elástica mínima de 30\%

\begin{tabular}{cccc}
\hline \multirow{2}{*}{ ligante asfáltico } & \multicolumn{3}{c}{ temperatura $\left({ }^{\circ} \mathrm{C}\right)$} \\
\cline { 2 - 4 } & 70 & 76 & 82 \\
\hline REDUC & 1,95 & $>2,00$ & $>2,00$ \\
LUBNOR & 0,00 & 0,75 & - \\
\hline
\end{tabular}


Jnr 100Pa, $52^{\circ} \mathrm{C}$

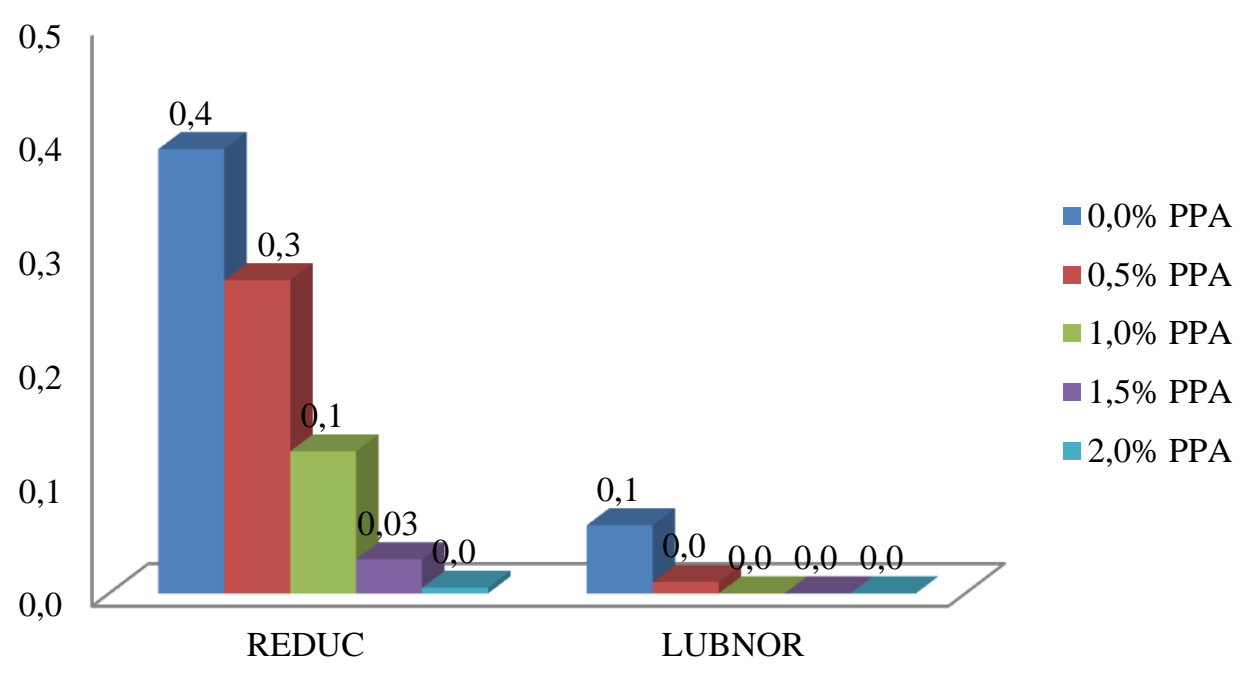

Figura 5.15 - Compliância não-recuperável a $100 \mathrm{~Pa}$, a $52^{\circ} \mathrm{C}$

Jnr $100 \mathrm{~Pa}, \mathbf{5 8}^{\circ} \mathrm{C}$

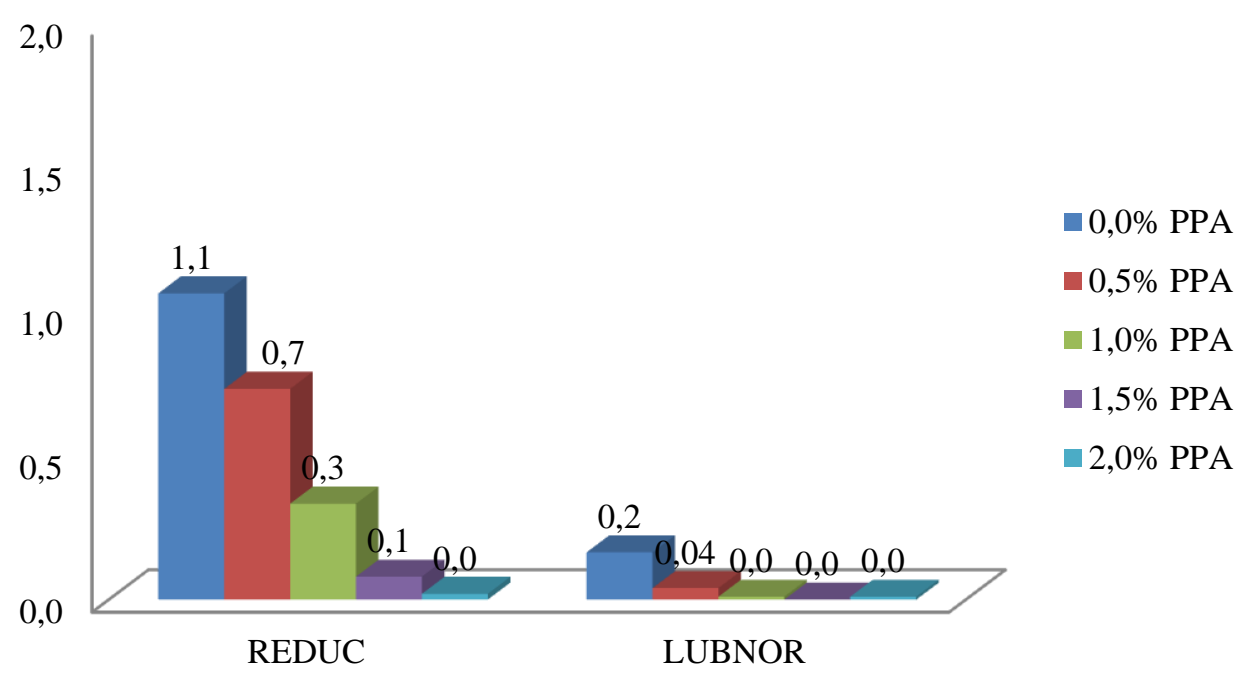

Figura 5.16 - Compliância não-recuperável a $100 \mathrm{~Pa}$, a $58^{\circ} \mathrm{C}$

Observa-se que há uma diminuição do valor de $\mathrm{J}_{\mathrm{nr}}$ com o aumento do teor de PPA e um aumento do valor de $\mathrm{J}_{\mathrm{nr}}$ com o aumento da temperatura. Os valores de $\mathrm{J}_{\mathrm{nr}}$ do LUBNOR são menores que os valores de $\mathrm{J}_{\mathrm{nr}}$ do REDUC. Mais uma vez, a diferença entre os valores de $\mathrm{J}_{\mathrm{nr}}$ do LUBNOR e do REDUC diminui com o aumento do teor de PPA, uma vez que, como o REDUC é muito mais sensível à adição de PPA nas temperaturas altas (Tabelas 5.5 e 5.6), a diferença de rigidez entre o LUBNOR e o REDUC diminui com a adição de PPA. Os resultados confirmam a suposição de que quanto mais rígido for o ligante asfáltico, mais resistente à deformação permanente. 
Jnr 100Pa, $64^{\circ} \mathrm{C}$

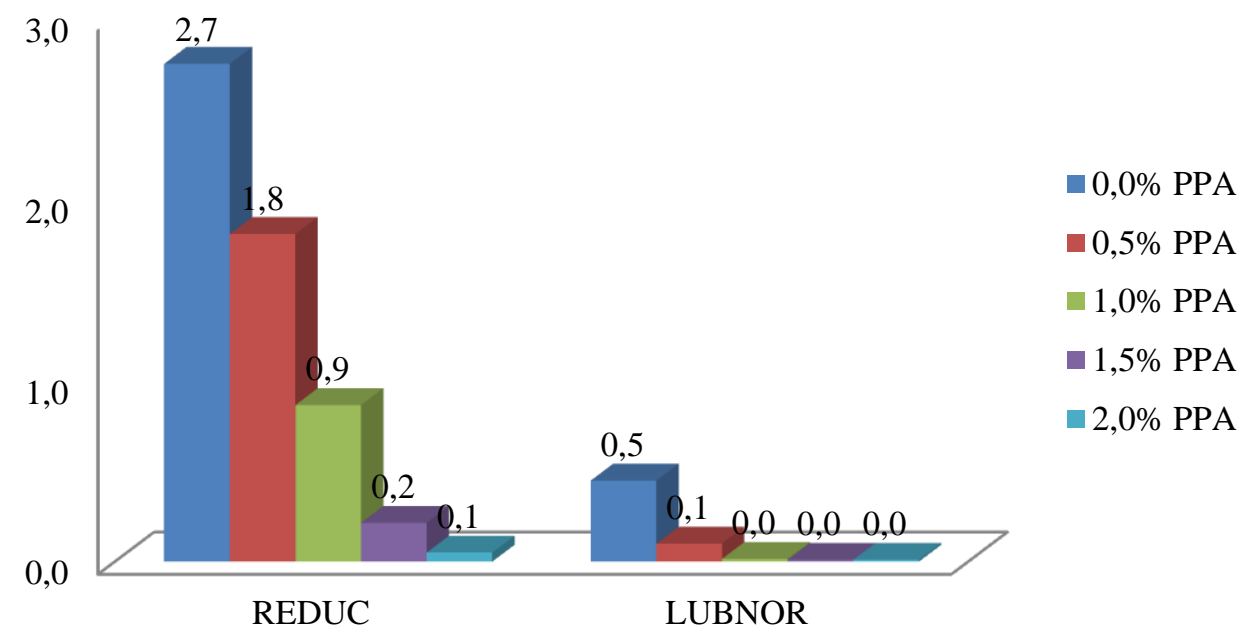

Figura 5.17 - Compliância não-recuperável a $100 \mathrm{~Pa}$, a $64^{\circ} \mathrm{C}$

Jnr 100Pa, $70^{\circ} \mathrm{C}$

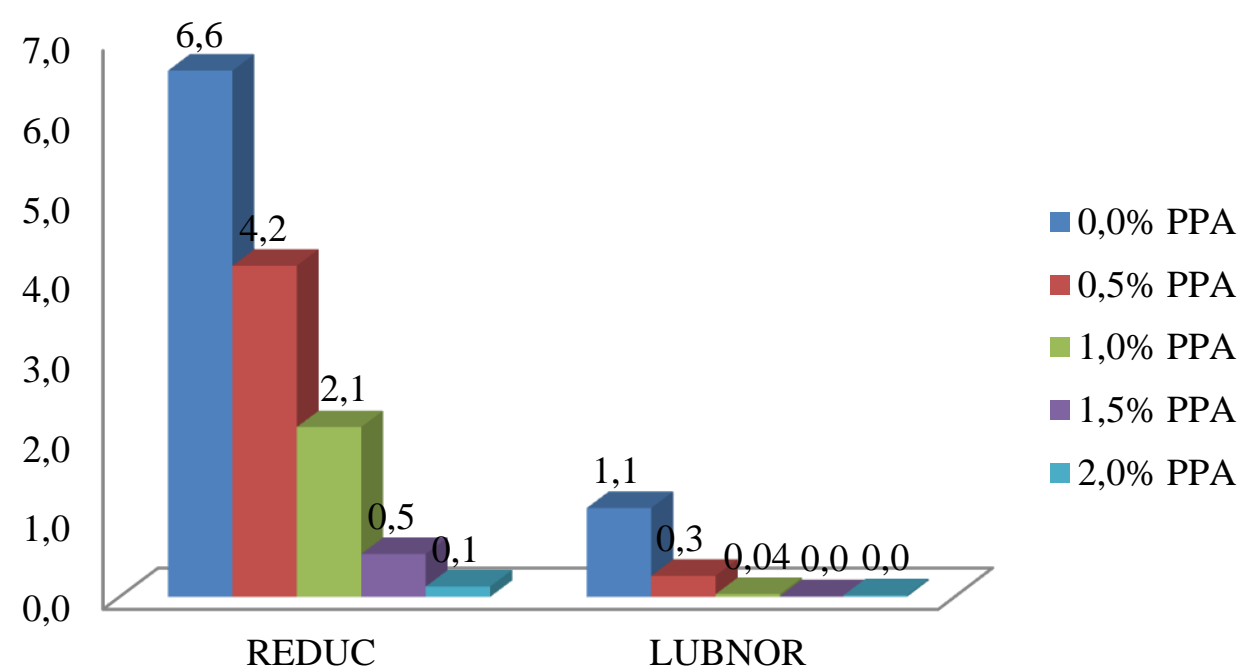

Figura 5.18 - Compliância não-recuperável a $100 \mathrm{~Pa}$, a $70^{\circ} \mathrm{C}$

A Tabela 5.6 apresenta as variações de $\mathrm{J}_{\mathrm{nr}}$, a $100 \mathrm{~Pa}$, do LUBNOR e do REDUC modificados com os quatro teores de PPA, na condição envelhecida a curto prazo, comparativamente ao ligante asfáltico de base puro, também na condição envelhecida a curto prazo.

A Tabela 5.7 apresenta o mesmo tipo de comparação para os valores de $\mathrm{J}_{\mathrm{nr}}$ a $3.200 \mathrm{~Pa}$. A variação de $J_{n r}$ é expressa em termos de quantas vezes o $J_{n r}$ aumentou ou diminuiu por conta da adição de PPA, em função da temperatura, em relação aos valores de compliância não-recuperável do ligante asfáltico de base. Valores acima de 1,0 indicam um aumento na 
compliância não-recuperável do ligante asfáltico modificado em relação ao ligante asfáltico de base e valores inferiores a 1,0 indicam que o ligante asfáltico modificado apresenta $u m \mathrm{~J}_{\mathrm{nr}}$ menor que o ligante asfáltico de base. Observa-se que a adição de PPA é mais expressiva para o REDUC do que para o LUBNOR. Observa-se também que o efeito do PPA diminui com o aumento de temperatura.

Jnr $100 \mathrm{~Pa}, 76^{\circ} \mathrm{C}$

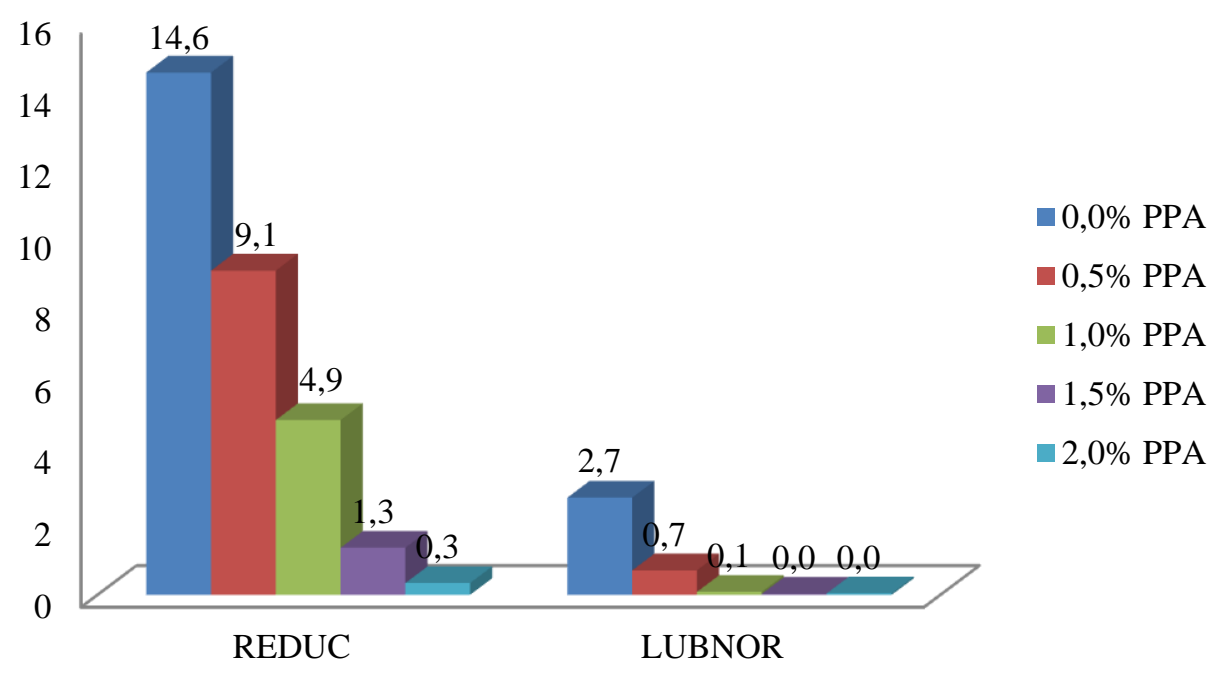

Figura 5.19 - Compliância não-recuperável a $100 \mathrm{~Pa}$, a $76^{\circ} \mathrm{C}$

Jnr 3200Pa, $5^{\circ} \mathrm{C}$

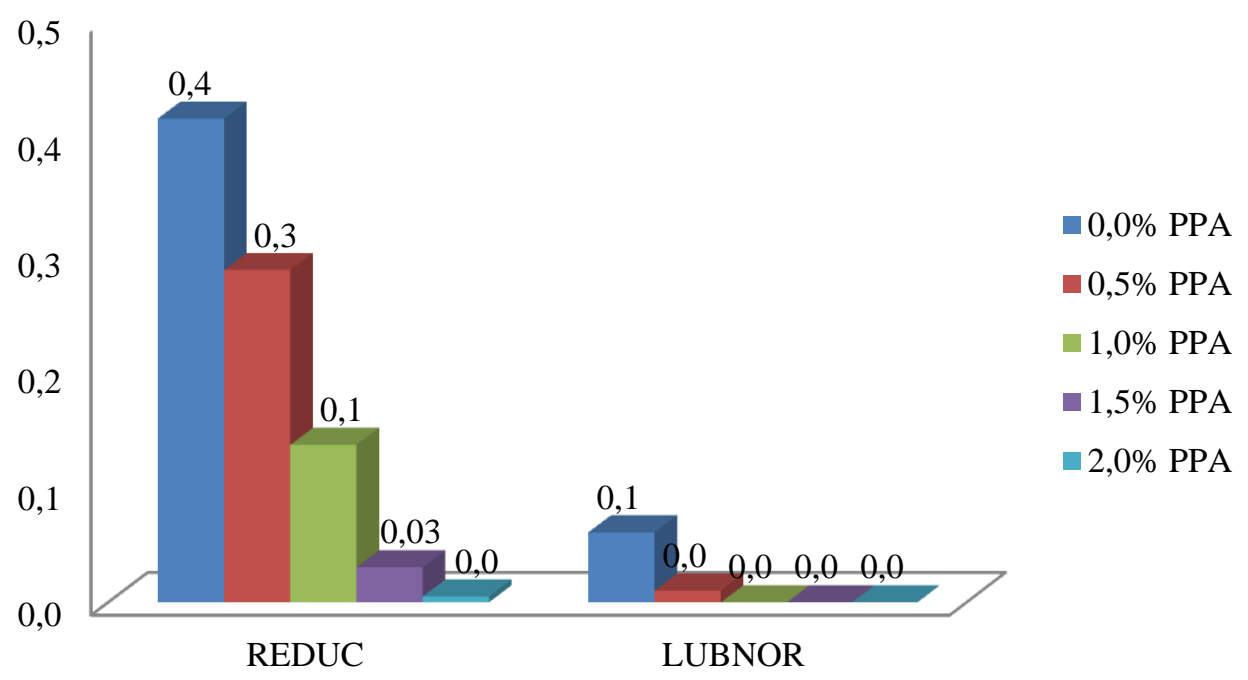

Figura 5.20 - Compliância não-recuperável a $3.200 \mathrm{~Pa}$, a $52^{\circ} \mathrm{C}$ 
Jnr 3200Pa, $5^{\circ} \mathrm{C}$

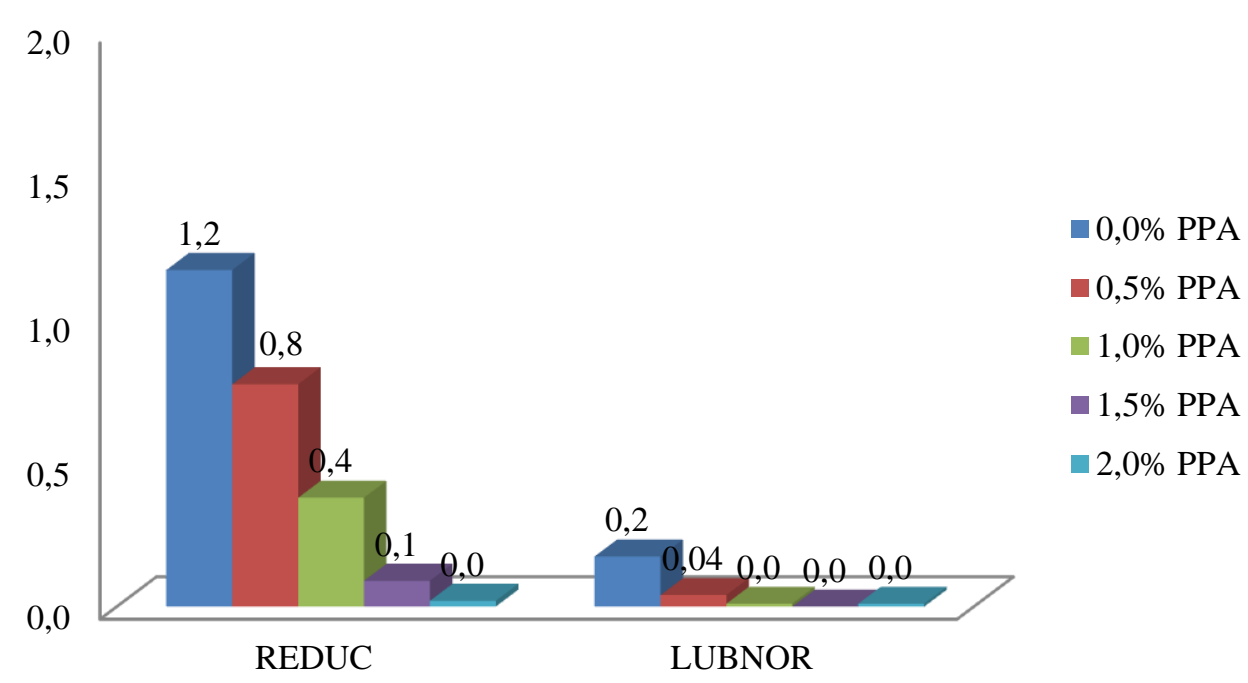

Figura 5.21 - Compliância não-recuperável a $3.200 \mathrm{~Pa}$, a $58^{\circ} \mathrm{C}$

Jnr $3200 P a, 64^{\circ} \mathrm{C}$

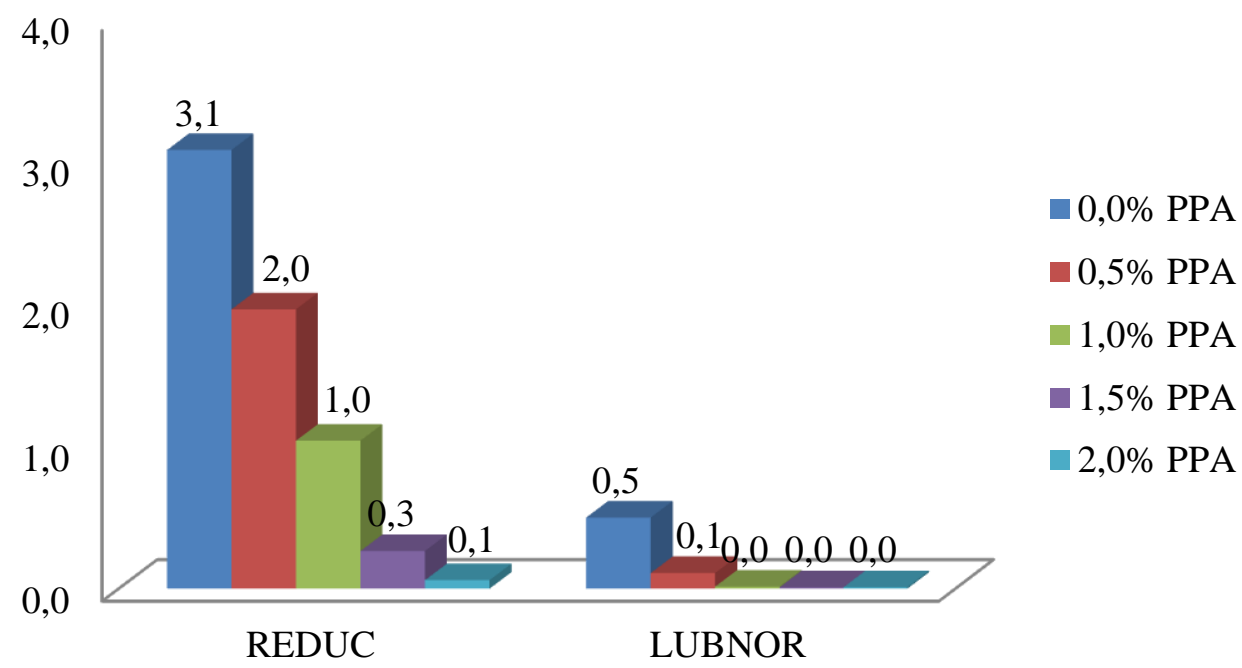

Figura 5.22 - Compliância não-recuperável a $3.200 \mathrm{~Pa}$, a $64^{\circ} \mathrm{C}$

A Tabela 5.8 apresenta as proporções de PPA mínimas necessárias para atingir o valor máximo de compliância não-recuperável de $2 \mathrm{kPa}^{-1}$ em cada temperatura. Para obter o valor máximo de $\mathrm{J}_{\mathrm{nr}}$ de $2 \mathrm{kPa}^{-1}$ utilizando o ligante asfáltico proveniente da REDUC, a temperatura alta do pavimento é $82^{\circ} \mathrm{C}$ e a proporção de PPA é de $1,95 \%$. 
Esta mesma análise não pôde ser realizada para o ligante asfáltico proveniente da LUBNOR uma vez que as amostras com baixa proporção de PPA não foram testadas nas temperaturas mais elevadas (abaixo da temperatura alta do PG).

\section{Jnr 3200Pa, $70^{\circ} \mathrm{C}$}

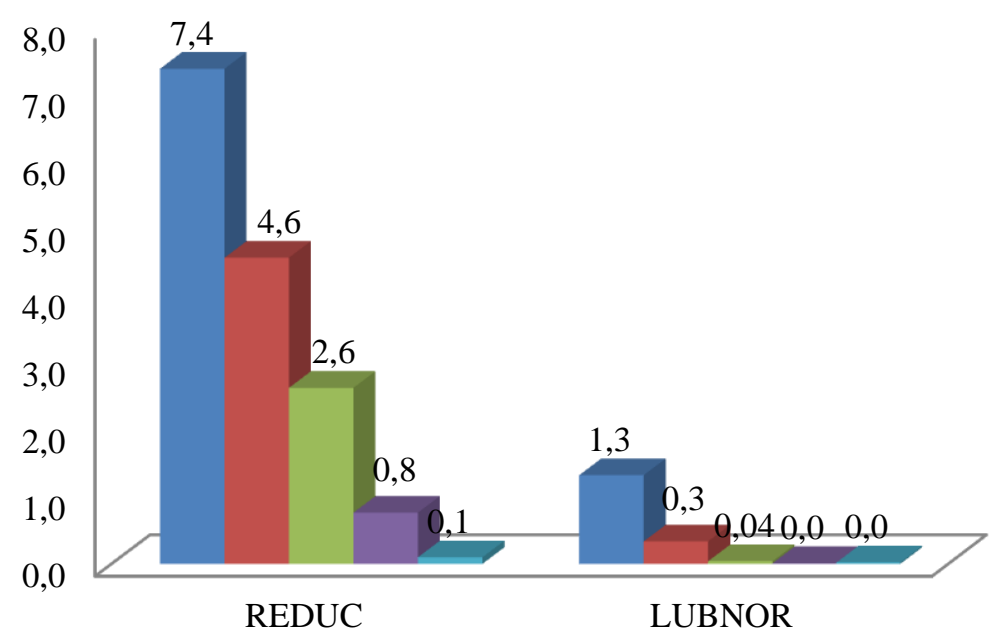

- $0,0 \%$ PPA

$\square, 5 \%$ PPA

$1,0 \%$ PPA

- 1,5\% PPA

-2,0\% PPA

Figura 5.23 - Compliância não-recuperável a 3.200 $\mathrm{Pa}$, a $70^{\circ} \mathrm{C}$

Jnr 3200Pa, $76^{\circ} \mathrm{C}$

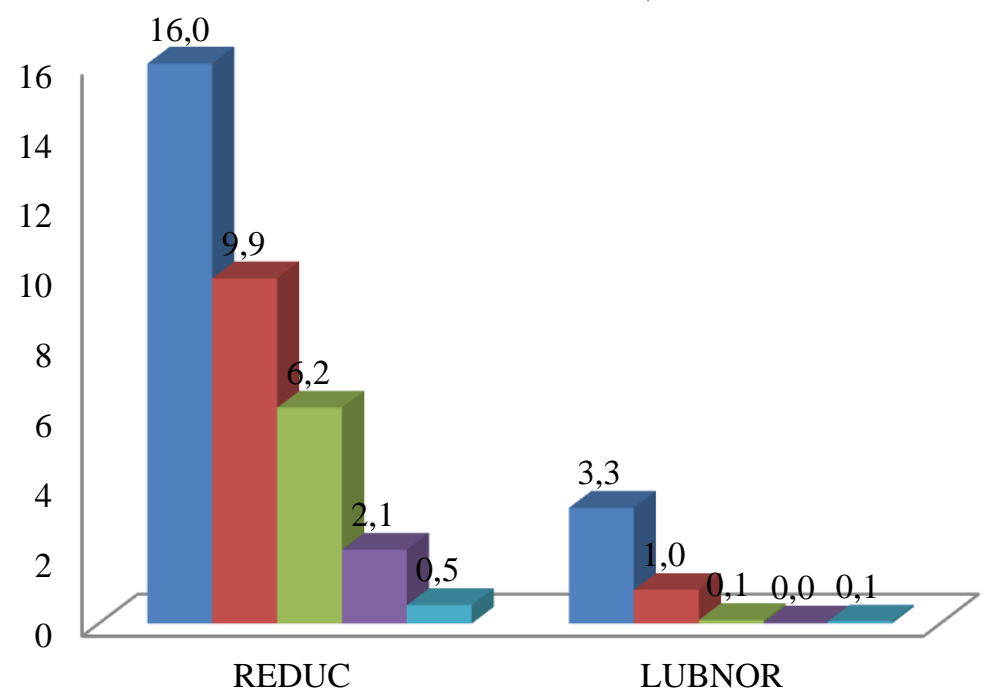

$\square, 0 \%$ PPA

- $0,5 \%$ PPA

$1,0 \%$ PPA

- $1,5 \%$ PPA

$2,0 \%$ PPA

Figura 5.24 - Compliância não-recuperável a $3.200 \mathrm{~Pa}$, a $76^{\circ} \mathrm{C}$ 
Tabela 5.6 - Variações dos valores de Jnr, a 100Pa, para o REDUC e LUBNOR em função da temperatura

\begin{tabular}{cccccc}
\hline & \multicolumn{5}{c}{$\mathbf{R E D U C}$} \\
\% PPA & $\mathbf{5 2}^{\circ} \mathbf{C}$ & $\mathbf{5 8}^{\circ} \mathbf{C}$ & $\mathbf{6 4}^{\circ} \mathbf{C}$ & $\mathbf{7 0}^{\circ} \mathbf{C}$ & $\mathbf{7 6}^{\circ} \mathbf{C}$ \\
\hline $\mathbf{0 , 0}$ & 1,0 & 1,0 & 1,0 & 1,0 & 1,0 \\
$\mathbf{0 , 5}$ & 1,4 & 1,4 & 1,5 & 1,6 & 1,6 \\
$\mathbf{1 , 0}$ & 3,1 & 3,2 & 3,2 & 3,1 & 3,0 \\
$\mathbf{1 , 5}$ & 13,0 & 13,3 & 12,8 & 12,2 & 11,0 \\
$\mathbf{2 , 0}$ & 78,0 & 53,3 & 54,9 & 50,7 & 44,2 \\
\hline \multicolumn{5}{c}{$\mathbf{L U B N O R}$} \\
& $\mathbf{5 2}^{\circ} \mathbf{C}$ & $\mathbf{5 8}^{\circ} \mathbf{C}$ & $\mathbf{6 4}^{\circ} \mathbf{C}$ & $\mathbf{7 0}^{\circ} \mathbf{C}$ & $\mathbf{7 6}^{\circ} \mathbf{C}$ \\
\hline $\mathbf{0 , 0}$ & 1,0 & 1,0 & 1,0 & 1,0 & 1,0 \\
$\mathbf{0 , 5}$ & 6,0 & 4,1 & 4,5 & 4,2 & 4,0 \\
$\mathbf{1 , 0}$ & - & 16,5 & 30,0 & 32,0 & 34,1 \\
$\mathbf{1 , 5}$ & - & - & 45,0 & 112,0 & 109,2 \\
$\mathbf{2 , 0}$ & - & 16,5 & 45,0 & 56,0 & 68,3 \\
\hline
\end{tabular}

Tabela 5.7 - Variações dos valores de Jnr, a 3.200Pa, para o REDUC e LUBNOR em função da temperatura

\begin{tabular}{cccccc}
\hline \multicolumn{5}{c}{ REDUC } \\
\% PPA & $\mathbf{5 2}^{\circ} \mathbf{C}$ & $\mathbf{5 8}^{\circ} \mathbf{C}$ & $\mathbf{6 4}^{\circ} \mathbf{C}$ & $\mathbf{7 0}^{\circ} \mathbf{C}$ & $\mathbf{7 6}^{\circ} \mathbf{C}$ \\
\hline $\mathbf{0 , 0}$ & 1,0 & 1,0 & 1,0 & 1,0 & 1,0 \\
$\mathbf{0 , 5}$ & 1,5 & 1,5 & 1,6 & 1,6 & 1,6 \\
$\mathbf{1 , 0}$ & 3,1 & 3,1 & 3,0 & 2,8 & 2,6 \\
$\mathbf{1 , 5}$ & 13,8 & 13,0 & 11,6 & 9,6 & 7,6 \\
$\mathbf{2 , 0}$ & 83,0 & 58,5 & 51,3 & 75,3 & 30,4 \\
\hline \multicolumn{5}{c}{$\mathbf{L U B N O R}$} \\
\hline $\mathbf{0 , 0}$ & 1,0 & 1,0 & 1,0 & 1,0 & 1,0 \\
$\mathbf{0 , 5}$ & 6,0 & 4,4 & 4,5 & 4,0 & 3,4 \\
$\mathbf{1 , 0}$ & - & 17,5 & 33,3 & 33,1 & 33,0 \\
$\mathbf{1 , 5}$ & - & - & 50,0 & 132,5 & 110,0 \\
$\mathbf{2 , 0}$ & - & 17,5 & 50,0 & 66,3 & 55,0 \\
\hline
\end{tabular}

Tabela 5.8 - Teores mínimos de PPA para obter a compliância não-recuperável máxima de $2 \mathrm{kPa}^{-1}$

\begin{tabular}{cccc}
\hline \multirow{2}{*}{ ligante asfáltico } & \multicolumn{3}{c}{ temperatura $\left({ }^{\circ} \mathrm{C}\right)$} \\
\cline { 2 - 4 } & 70 & 76 & 82 \\
\hline REDUC & 1,15 & 1,50 & 1,95 \\
LUBNOR & 0,00 & 0,25 & - \\
\hline
\end{tabular}




\subsubsection{Classificação do nível de tráfego}

A Tabela 5.9 apresenta a classificação do nível de tráfego que os pavimentos projetados utilizando estes ligantes asfálticos suportariam, nas temperaturas de formação de trilha de roda. Estes níveis de carregamento de tráfego foram determinados por meio dos valores limites de $\mathrm{J}_{\mathrm{nr}}$ a 3.200Pa, conforme indicado na Tabela 5.1, onde estes níveis foram designados como padrão (Standard), pesado (Heavy), muito pesado (Very heavy) e extremamente pesado (Extremely heavy) (D'ANGELO, 2010).

\begin{tabular}{cccccc} 
Tabela $5.9-$ Classificação do nível de tráfego dos ligantes asfálticos quanto ao valor \\
\hline ligante asfáltico & $\mathbf{5 2}^{\circ} \mathbf{C}$ & $\mathbf{5 8}^{\circ} \mathbf{C}$ & $\mathbf{6 4}^{\circ} \mathbf{C}$ & $\mathbf{7 0}^{\circ} \mathbf{C}$ & $\mathbf{7 6}^{\circ} \mathbf{C}$ \\
\hline LUBNOR & E & E & E & H & S \\
LUBNOR + 0,5\% PPA & E & E & E & E & V \\
LUBNOR + 1,0\% PPA & E & E & E & E & E \\
LUBNOR + 1,5\% PPA & E & E & E & E & E \\
LUBNOR + 2,0\% PPA & E & E & E & E & E \\
REDUC & E & H & S & - & - \\
REDUC + 0,5\% PPA & E & V & H & - & - \\
REDUC + 1,0\% PPA & E & E & V & S & - \\
REDUC + 1,5\% PPA & E & E & E & V & S \\
REDUC + 2,0\% PPA & E & E & E & E & V \\
\hline
\end{tabular}

O ligante asfáltico da LUBNOR puro suporta um tráfego extremamente pesado (número de solicitações maior que 100 milhões) em pavimentos cuja temperatura é de $64^{\circ} \mathrm{C}$ ou menos. Já o ligante asfáltico da REDUC suporta este tráfego apenas para pavimentos cuja temperatura é igual ou inferior a $52^{\circ} \mathrm{C}$. O LUBNOR puro ainda suporta um tráfego pesado (número de solicitações maior que 10 milhões) em locais onde a temperatura do pavimento é igual ou inferior a $70^{\circ} \mathrm{C}$ e um tráfego padrão (número de solicitações menor que 10 milhões) onde a temperatura do pavimento é igual ou inferior $76^{\circ} \mathrm{C}$. Já o REDUC puro suporta um tráfego pesado em locais onde a temperatura do pavimento é igual ou inferior a $58^{\circ} \mathrm{C}$ e um tráfego padrão para pavimentos em que a temperatura é igual ou inferior a $64^{\circ} \mathrm{C}$. O que se nota é que o LUBNOR puro atende a tráfegos mais pesados para uma mesma temperatura do pavimento em comparação ao REDUC. O REDUC atende apenas a tráfego leve para 
temperaturas do pavimento de até $64^{\circ} \mathrm{C}$, ao passo que o LUBNOR atende a tráfego leve para temperaturas de até $76^{\circ} \mathrm{C}$.

O ligante asfáltico da LUBNOR modificado com 1,0\% ou mais de PPA suporta um tráfego extremamente pesado para pavimentos cujas temperaturas máximas são de até $76^{\circ} \mathrm{C}$. O ligante asfáltico da REDUC modificado com 1,0\% de PPA suporta apenas um tráfego padrão em locais onde a temperatura do pavimento é de no máximo $70^{\circ} \mathrm{C}$ e um tráfego muito pesado (número de solicitações maior que 30 milhões) em locais onde a temperatura do pavimento é de no máximo $64^{\circ} \mathrm{C}$. O ligante asfáltico da REDUC modificado com $2,0 \%$ de PPA suporta um tráfego muito pesado em locais onde a temperatura do pavimento é igual ou inferior a $76^{\circ} \mathrm{C}$, enquanto o ligante asfáltico da LUBNOR modificado com 2,0\% de PPA suporta um tráfego extremamente pesado em temperaturas do pavimento até $76^{\circ} \mathrm{C}$. $\mathrm{O}$ que se nota, em todas as temperaturas, é que o CAP LUBNOR puro e nas suas versões modificadas com PPA suporta tráfegos sempre superiores aos indicados para as formulações com CAP REDUC. Tomando por base o tráfego extremamente pesado, as formulações com CAP LUBNOR atendem a este nível de tráfego em temperaturas do pavimento de 6 a $18^{\circ} \mathrm{C}$ acima das temperaturas em que as formulações com CAP REDUC atendem a este nível de tráfego.

Para formulações usando o CAP LUBNOR, o teor de PPA máximo recomendado é de $1,0 \%$, já que este teor é suficiente para atender o tráfego extremamente pesado até a temperatura do pavimento de $76^{\circ} \mathrm{C}$. Já as formulações obtidas com o CAP REDUC não atendem a este nível de tráfego a $76^{\circ} \mathrm{C}$ mesmo quando é adicionado o teor de $2 \%$ de PPA.

No Brasil, a temperatura alta do PG máxima dos ligantes asfálticos que são requeridos é de $70^{\circ} \mathrm{C}$ (Figura 5.25). Para este máximo, o LUBNOR puro suporta um tráfego pesado, o LUBNOR modificado com 0,5\% ou mais de PPA suporta um tráfego extremamente pesado. Já o REDUC puro e o REDUC modificado com 0,5\% de PPA não suportam nenhum tráfego para estas regiões que exigem um ligante asfáltico de PG 70-10. O REDUC modificado com 1,0, 1,5 e 2,0\% de PPA suportam um tráfego padrão, muito pesado e extremamente pesado, respectivamente. Para formulações usando o CAP LUBNOR, o teor de PPA recomendado para pavimentos com temperatura máxima de $70^{\circ} \mathrm{C}$ e para atender tráfego extremamente pesado é de 0,5\%. Já para as formulações obtidas com o CAP REDUC, o teor de PPA recomendado para pavimentos com temperatura máxima de $70^{\circ} \mathrm{C}$ e para atender tráfego extremamente pesado é de $2,0 \%$. 


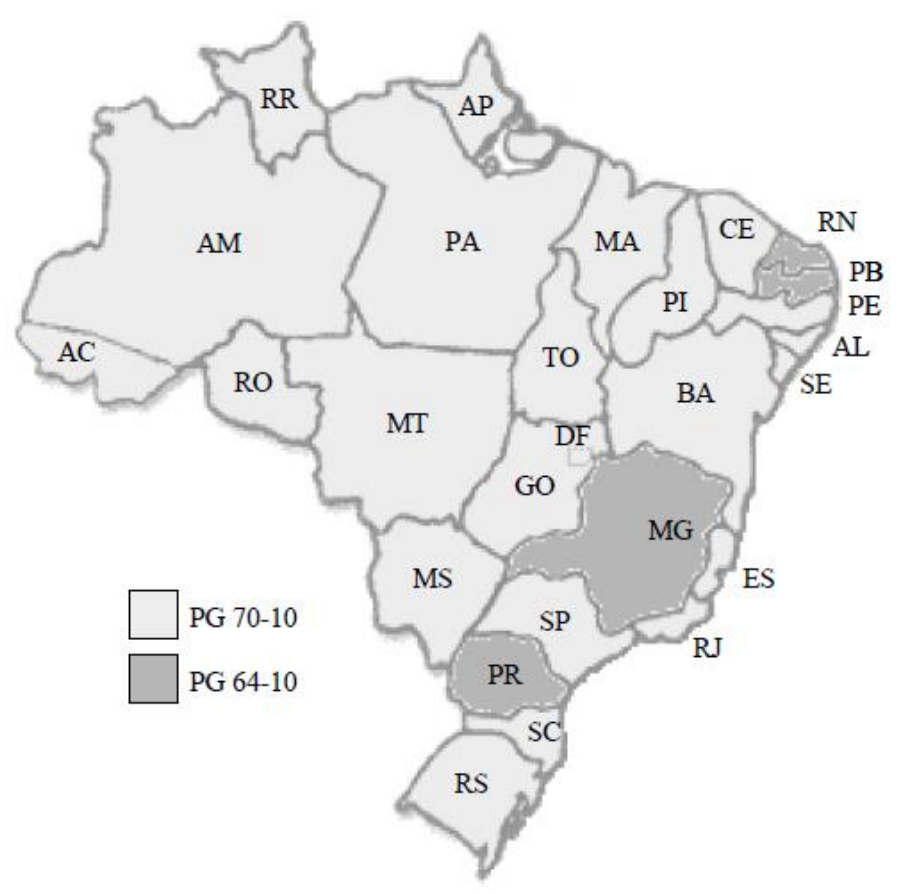

Figura 5.25 - Grau de desempenho sugerido para ligantes asfálticos por regiões do Brasil (Cunha, 2007)

Já para os Estados Unidos, a temperatura alta do $\mathrm{PG}$ máxima dos pavimentos é $76^{\circ} \mathrm{C}$ (Figura 5.26). Para formulações usando o CAP LUBNOR, o teor de PPA máximo recomendado é de $1,0 \%$, já que este teor é suficiente para atender o tráfego extremamente pesado até a temperatura do pavimento de $76^{\circ} \mathrm{C}$ e as formulações obtidas com o REDUC não atendem a este nível de tráfego a $76^{\circ} \mathrm{C}$ mesmo quando é adicionado o teor de $2 \%$ de PPA.

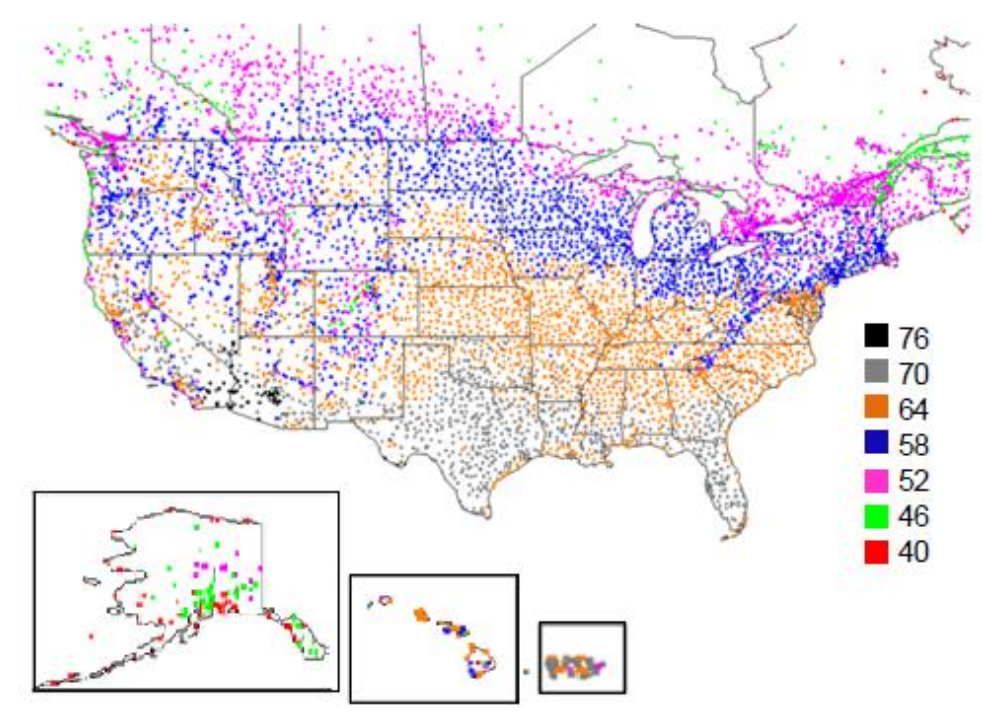

Figura 5.26 - Grau de desempenho sugeridos para ligantes asfálticos por regiões dos Estados Unidos (Asphalt Institute, 2010) 


\subsubsection{Sensibilidade à mudança no nível de tensão $\left(\mathbf{J}_{\mathbf{n r}, \text { diff }}\right)$}

A fim de assegurar que o ligante asfáltico não seja excessivamente suscetível a alterações no nível de tensão, a relação $\mathrm{J}_{\mathrm{nr} \text {,diff }}$ entre os valores de $\mathrm{J}_{\mathrm{nr}}$ a 100 e 3.200 Pa foi calculada e os resultados obtidos para o LUBNOR estão apresentados na Tabela 5.10 e para o REDUC estão apresentados na Tabela 5.11.

Tabela $5.10-\mathrm{J}_{\text {nr,diff }}$ do LUBNOR puro e modificados com PPA

\begin{tabular}{cccccc}
\hline \multirow{2}{*}{$\%$ PPA } & \multicolumn{5}{c}{ LUBNOR } \\
\cline { 2 - 6 } & $\mathbf{5 2}^{\circ} \mathbf{C}$ & $\mathbf{5 8}^{\circ} \mathbf{C}$ & $\mathbf{6 4}^{\circ} \mathbf{C}$ & $\mathbf{7 0}^{\circ} \mathbf{C}$ & $\mathbf{7 6}^{\circ} \mathbf{C}$ \\
\hline $\mathbf{0 , 0}$ & $0 \%$ & $6 \%$ & $10 \%$ & $15 \%$ & $17 \%$ \\
$\mathbf{0 , 5}$ & $0 \%$ & $0 \%$ & $9 \%$ & $21 \%$ & $29 \%$ \\
$\mathbf{1 , 0}$ & $0 \%$ & $0 \%$ & $0 \%$ & $13 \%$ & $20 \%$ \\
$\mathbf{1 , 5}$ & $0 \%$ & $0 \%$ & $0 \%$ & $0 \%$ & $17 \%$ \\
$\mathbf{2 , 0}$ & $0 \%$ & $0 \%$ & $0 \%$ & $0 \%$ & $33 \%$ \\
\hline
\end{tabular}

Tabela 5.11 - $\mathbf{J}_{\text {nr,diff }}$ do REDUC puro e modificados com PPA

\begin{tabular}{cccccc}
\hline \multirow{2}{*}{$\% \mathbf{P P A}$} & \multicolumn{5}{c}{ REDUC } \\
\cline { 2 - 6 } & $\mathbf{5 2}^{\circ} \mathbf{C}$ & $\mathbf{5 8}^{\circ} \mathbf{C}$ & $\mathbf{6 4}^{\circ} \mathbf{C}$ & $\mathbf{7 0}^{\circ} \mathbf{C}$ & $\mathbf{7 6}^{\circ} \mathbf{C}$ \\
\hline $\mathbf{0 , 0}$ & $6 \%$ & $9 \%$ & $11 \%$ & $11 \%$ & $9 \%$ \\
$\mathbf{0 , 5}$ & $4 \%$ & $5 \%$ & $8 \%$ & $9 \%$ & $8 \%$ \\
$\mathbf{1 , 0}$ & $7 \%$ & $12 \%$ & $16 \%$ & $19 \%$ & $20 \%$ \\
$\mathbf{1 , 5}$ & $0 \%$ & $11 \%$ & $19 \%$ & $29 \%$ & $37 \%$ \\
$\mathbf{2 , 0}$ & $0 \%$ & $0 \%$ & $17 \%$ & $33 \%$ & $37 \%$ \\
\hline
\end{tabular}

Conforme recomendação (ANDERSON et al., 2010; ASPHALT INSTITUTE, 2010a,

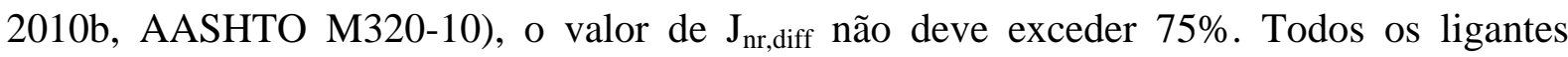
asfálticos modificados com PPA resultaram em amostras mais sensíveis à tensão que os seus respectivos sem PPA. Isto indica que a adição de PPA aumenta a sensibilidade dos ligantes asfálticos a variações de tensão, como ocorre tipicamente com ligantes asfálticos modificados, tornando-os mais propensos a acumular deformações plásticas. Em termos práticos, a adição de PPA aumenta a sensibilidade à variação de tensão dos ligantes asfálticos, mas este aumento não é excessivo, uma vez que os resultados não excederam o limite permitido por norma (AASHTO M320-10). 


\section{CAPÍTULO 6. FADIGA EM LIGANTES ASFÁLTICOS}

Neste capítulo é feita uma revisão bibliográfica acerca dos ensaios de fadiga em ligantes asfálticos, onde é feita uma comparação entre o ensaio de fadiga em ligantes asfálticos time sweep e os ensaios acelerados de fadiga (LAS e LAS modificado) em ligantes asfálticos. O capítulo também traz um detalhamento do ensaio acelerado de fadiga em ligantes asfáltics desenvolvidos recentemente e os critérios de ruptura propostos pelos mesmos. Também são apresentados os resultados obtidos pelo ensaio LAS modificado para os ligantes puro e modificados, envelhecidos a curto e longo prazo, e as análises destes resultados por meio do comprimento de ruptura $\left(\mathrm{a}_{\mathrm{f}}\right)$.

\subsection{INTRODUÇÃO DE FADIGA EM LIGANTES ASFÁLTICOS}

A resistência ao dano provocado por fadiga tem um efeito significativo no tempo de serviço dos pavimentos asfálticos. Trincas por fadiga são causadas por carregamentos de carga repetidos e podem ocorrer em temperaturas de baixas a intermediárias (BOLOTIN, 1999). Existe um consenso de que o ligante asfáltico exerce um papel crítico quanto à resistência ao dano por fadiga e, por esta razão, há um grande esforço no sentido de desenvolver um procedimento de ensaio capaz de determinar a tolerância à fadiga dos ligantes asfálticos.

Em meados da década de 1980, o programa SHRP (Strategic Highway Research Program) foi iniciado, com o objetivo de investigar novas propriedades reológicas a serem aplicadas na caracterização dos ligantes asfálticos. Este esforço de pesquisa culminou no lançamento da especificação Superpave (Superior Performance Asphalt Pavements), na qual o parâmetro $\mathrm{G}^{*} \operatorname{sen} \delta$ foi adotado como critério de fadiga da especificação. O que se pretendia, à época, era expressar a resistência dos ligantes asfálticos ao trincamento por fadiga, em resposta à necessidade de adotar um parâmetro simples e de fácil obtenção. Posteriormente à implementação da especificação Superpave, constatou-se que o parâmetro G*sen $\delta$ seria inadequado para avaliar os ligantes asfálticos, pois não se relacionava bem com o acúmulo de dano por fadiga de misturas asfálticas, quando avaliadas por ensaio de fadiga em viga sob deformação controlada (SHENOY, 2002). Bahia et al., (1999) também constataram que o parâmetro $G^{*} \operatorname{sen} \delta$ seria ineficiente em detectar a resistência à fadiga, especialmente para ligantes asfálticos modificados, empregando o ensaio de fadiga em viga. A ineficácia deste parâmetro seria devida ao fato de ser determinado por meio de ensaios realizados na região de 
viscoelasticidade linear, para níveis baixos de deformação, enquanto o fenômeno real se daria na região de viscoelasticidade não-linear, sob grandes deformações.

Durante o projeto NCHRP 9-10 (National Cooperative Highway Research Program), uma varredura do módulo ( $\left.\mathrm{G}^{*}\right)$ em função do tempo (time sweep) foi proposta (BAHIA et al., 2001) para avaliar a resistência à fadiga dos ligantes asfálticos. Seria uma alternativa para tentar contornar as deficiências da atual especificação relativas ao controle do trincamento do ligante asfáltico por fadiga. Este ensaio se baseia na definição de dano por fadiga como a degradação da integridade do material pela ação de cargas repetidas. O procedimento de ensaio possibilita a escolha da amplitude da carga, o que permite considerar a estrutura do pavimento e as cargas devidas ao tráfego. Se o ensaio for realizado em níveis de tensão suficientes, o ensaio pode medir indicadores relevantes do desempenho à fadiga (ANDERSON et al., 2001; MARTONO et al., 2007). O time sweep tem mostrado uma boa correlação com os resultados de vida de fadiga de misturas asfálticas, indicando que é capaz de capturar a contribuição do ligante asfáltico sobre a resistência à fadiga das misturas asfálticas (BAHIA et al., 2001). No entanto, é um ensaio que pode ser excessivamente demorado, em virtude do tempo necessário para levar o material à falha, tornando inviável sua manutenção em especificações.

O desenvolvimento de um procedimento acelerado para determinar a resistência à fadiga de ligantes asfálticos tem sido um desafio para a comunidade científica (JONHSON, 2010; HINTZ, 2012). Johnson (2010) desenvolveu o ensaio LAS (Linear Amplitude Sweep) para determinar características dos ligantes asfálticos relacionadas à fadiga. Este ensaio acelerado de fadiga é dividido em duas etapas: (i) uma varredura de frequência e (ii) uma varredura de amplitude de deformação. Na primeira etapa (varredura de frequência), as propriedades viscoelásticas na região linear são determinadas com o intuito de estabelecer um quadro de referência apropriado para avaliar o acúmulo do dano na amostra. Na segunda etapa (varredura de amplitude de deformação), é realizado um ensaio em que o material é levado à fratura, por meio do qual os parâmetros do modelo de fadiga são determinados. A teoria do dano viscoelático contínuo (VECD - Viscoelastic Continuum Damage) é utilizada na análise dos dados e na determinação do modelo de fadiga do ligante asfáltico. Este teoria utiliza o desvio do comportamento viscoelástico linear e a redução na rigidez da amostra para caracterizar o aumento do dano. O ensaio proposto pelo Johnson (2010) é especificado em termos de amplitude de deformação, considerando que o raio da amostra permaneceria constante durante todo o ensaio. No entanto, análises realizadas por meio de imagens 
mostraram que isto não acontece (HINTZ, 2012), indicando que o dano por fadiga não se dá pela redução de $\mathrm{G}^{*}$.

Hintz (2012) propôs algumas modificações no ensaio LAS e na análise dos resultados. $\mathrm{Na}$ sua pesquisa de doutorado, a autora utilizou dois ligantes asfálticos para verificar a hipótese de que a fratura é a responsável pela aparente redução no módulo durante o ensaio de varredura de $\mathrm{G}^{*}$ em função do tempo (time sweep). A autora sugere que os resultados sejam analisados utilizando o modelo baseado na fratura ao invés da análise pela teoria do dano contínuo viscoelástico, visto que foi visualizado que ocorrem macrofraturas durante o ensaio e que o raio da amostra não permanece constante ao longo do processo de fadiga do material. Hintz (2012) concluiu que o ensaio LAS desenvolvido por Johnson (2010) não é um ensaio de fadiga verdadeiro e é problemático devido às mudanças relativamente grandes e bruscas na amplitude de deformação. A autora recomenda que o carregamento de amplitude deva ser aumentado de maneira linear em cada ciclo de carregamento, ao invés de degraus de amplitude de deformação, com o intuito de eliminar as trincas na periferia da amostra ainda na fase de condicionamento da amostra. A autora chama a atenção para o fato que os reômetros não são projetados para mudanças de carregamento bruscas e que as modificações propostas no ensaio LAS serão mais compatíveis com as capacidades dos equipamentos em uso. Hintz (2012) também recomenda que o ensaio LAS seja considerado um ensaio de "tolerância à fadiga" em vez de um ensaio de "resistência à fadiga", uma vez que a tendência da propagação da trinca no ligante asfáltico no ensaio verdadeiro de fadiga é diferente da tendência observada no ensaio LAS modificado.

No estudo da fadiga de materiais asfálticos, considera-se comumente que o fenômeno se dê sob deformação constante, quando se parte do pressuposto de que a maioria dos pavimentos é esbelta e, nestas condições, a camada asfáltica deforma acompanhando a deformação das camadas subjacentes (BAHIA e ANDERSON, 1995). Existe uma forte tendência a se pensar que há um aumento da resistência à fadiga com a redução da rigidez dos ligantes asfálticos, mas vários estudos mostraram que a mistura asfáltica pode, mas não sempre, exibir um aumento na resistência à fadiga com o aumento da rigidez (VALLERGA et al., 1972; HARVEY E TSAI, 1997; HINTZ et al., 2011). Hintz et al. (2011) avaliou o efeito do enrijecimento provocado pelo envelhecimento na resistência à fadiga por meio do ensaio LAS proposto por Johnson (2010) e observou que a resistência à fadiga dos ligantes asfálticos é dependente do nível de tensão aplicado. Hintz et al. (2011) concluíram que o enrijecimento 
provocado pelo envelhecimento tem um efeito positivo na resistência à fadiga para níveis de tensão mais baixos, mas tem um efeito negativo para níveis de tensão mais elevados.

\subsection{Ensaio LAS}

O LAS foi proposto por Johnson (2010) como um ensaio de fadiga acelerado para ligantes asfálticos. O LAS é conduzido no reômetro de cisalhamento dinâmico (DSR) e pode ser realizado nas amostras envelhecidas a curto e/ou a longo prazo. A amostra é testada utilizando a geometria de placas paralelas de $8 \mathrm{~mm}$ de diâmetro com distância de $2 \mathrm{~mm}$ entre placas. O ensaio é dividido em duas etapas: (1) uma varredura de frequência entre 0,1 e $30 \mathrm{~Hz}$ é realizada para determinar as propriedades reológicas na região de viscoelasticidade linear, utilizando a amplitude de deformação de $0,1 \%$ e (2) uma varredura de amplitude de deformação entre 0,1 e $30 \%$ é realizada a uma frequência fixa de $10 \mathrm{~Hz}$. A sequência de carregamento consiste em intervalos de 10 segundos a uma amplitude de deformação constante, sendo cada intervalo seguido por outro intervalo com uma amplitude de deformação maior, conforme apresentado na Figura 6.1.

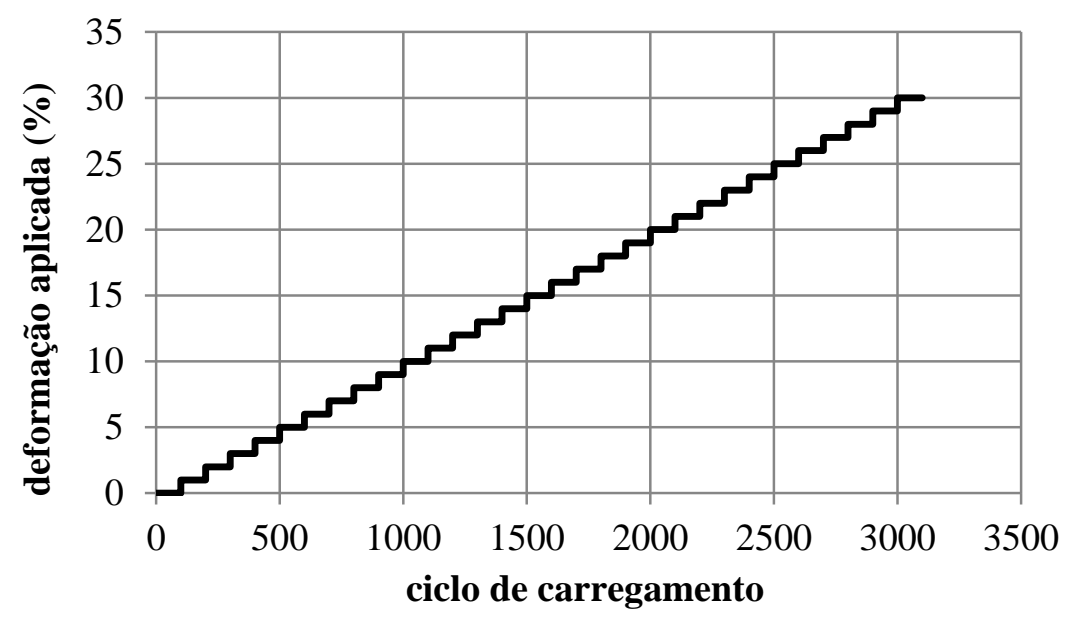

Figura 6.1 - Incremento da deformação (em degraus) no ensaio LAS (JOHNSON, 2010)

Os resultados obtidos a partir da varredura de amplitude de deformação e da caracterização reológica na região de viscoelasticidade linear são utilizados para determinar um modelo de fadiga do ligante asfáltico utilizando o princípio de dano contínuo 
viscoelástico. Para a caracterização da fadiga em ligantes asfálticos, o modelo é derivado da relação entre a carga aplicada e a vida de fadiga do material (Figura 6.2).

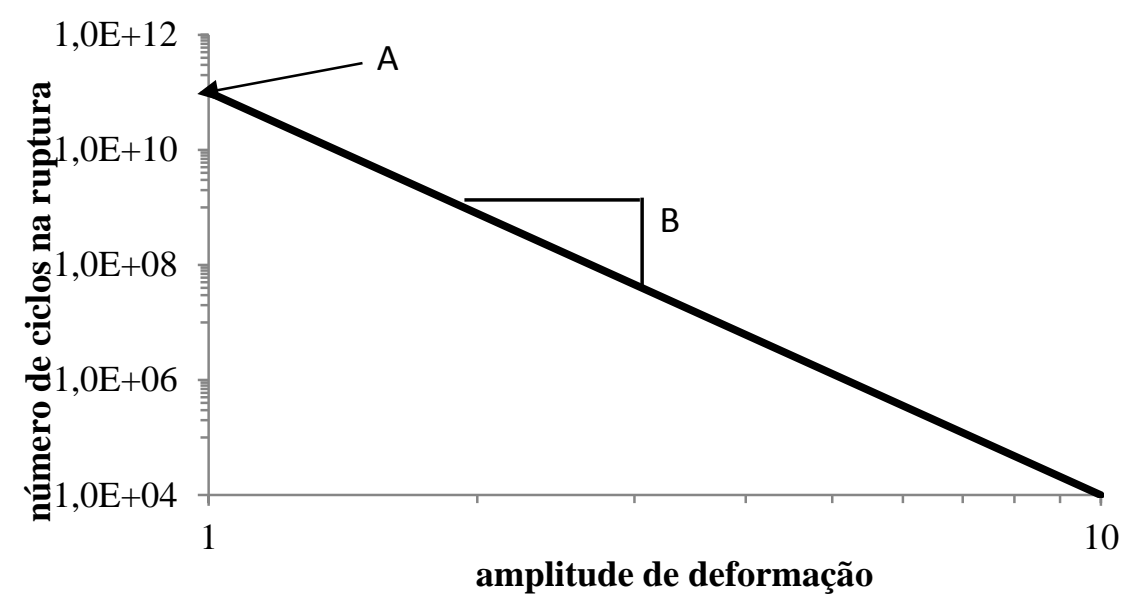

Figura 6.2 - Modelo de fadiga (JOHNSON, 2010)

Misturas asfálticas e ligantes asfálticos demonstram apresentar uma boa relação entre a carga aplicada e a vida de fadiga $\left(\mathrm{N}_{\mathrm{f}}\right)$ de acordo com a equação 6.1:

$\mathrm{N}_{\mathrm{f}}=\mathrm{A} \times\left(\gamma_{\text {máx }}\right)^{\mathrm{B}}$

onde os parâmetros A e B são característicos do material e $\gamma_{\max }$ é a deformação máxima esperada para uma dada estrutura do pavimento.

O parâmetro B é calculado de acordo com a equação 6.2:

$B=2 \times \alpha$

onde $\alpha$ foi definido por Johnson (2010) como $1+1 / m$, sendo $m$ a inclinação da reta do gráfico $\log -\log$ do módulo de armazenamento $\left(\left|G^{*}\right| \times \cos \delta\right)$ versus frequência.

O parâmetro A é calculado de acordo com a equação 6.3:

$A=\frac{f\left(D_{f}\right)^{k}}{k\left(\pi I_{D} C_{1} C_{2}\right)^{\alpha}}$ 
onde $f$ é a frequência $(10 \mathrm{~Hz}), \mathrm{D}_{f}$ é o valor de $\mathrm{D}(t)$ na ruptura, $k$ é definido como $k=1+$ $\left(1-C_{2}\right) \propto, I_{D}$ é o valor inicial de $\left|G^{*}\right|$, em MPA, do intervalo de amplitude de deformação de $1,0 \%$.

Os coeficientes $\mathrm{C}_{0}, \mathrm{C}_{1}$ e $\mathrm{C}_{2}$ podem ser determinados linearizando o modelo (Figura 6.3) encontrado a partir da relação entre $\left|G^{*}\right| \cdot \sin \delta$ e $\mathrm{D}(t)$, onde $\mathrm{D}(t)$ é o dano acumulado na amostra, calculado de acordo com a equação 6.4:

$$
D(t)=\sum_{\mathrm{i}=1}^{\mathrm{N}}\left[\pi \mathrm{I}_{\mathrm{D}} \gamma_{0}^{2}\left(\left|\mathrm{G}^{*}\right| \operatorname{sen} \delta_{\mathrm{i}-1}-\left|\mathrm{G}^{*}\right| \operatorname{sen} \delta_{\mathrm{i}}\right)\right]^{\frac{\alpha}{1+\alpha}}\left(\mathrm{t}_{\mathrm{i}}-\mathrm{t}_{\mathrm{i}-1}\right)^{\frac{1}{1+\alpha}}
$$

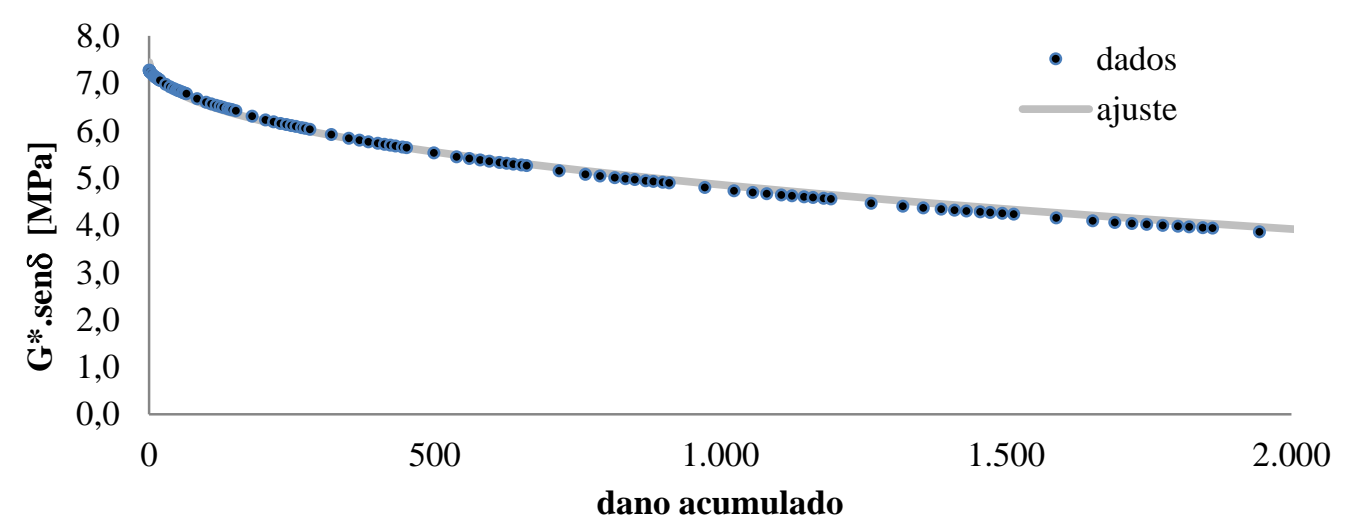

Figura 6.3 Curva do dano acumulado em função de G*/sen $\delta$ (JOHNSON, 2010)

A seleção de um bom critério de falha por trincas por fadiga para misturas asfálticas e ligantes asfálticos vêm sendo o assunto de muita discussão. $\mathrm{O}$ critério tradicional mais aceito é o de redução de 50\% do módulo inicial. No entanto, Johnson (2010) observou que a redução de $30 \%$ no valor de $\mathrm{G}^{*}$.sen $\delta$ proporciona uma correlação razoável entre os resultados do ensaio de varredura de $\mathrm{G}^{*}$ com o tempo e do LAS. Por esta razão, o valor de $\mathrm{D}(t)$ pode ser calculado utilizando a equação 6.5:

$D(t)=0.35 \cdot\left(\frac{C_{0}}{C_{1}}\right)^{1 / C_{2}}$

Hintz (2012) propôs modificações ao ensaio LAS, passando a denominá-lo ensaio LAS modificado. A diferença entre os dois procedimentos de ensaios é o formato da sequência de amplitudes de deformação. No LAS modificado, a amplitude de deformação 
aumenta linearmente em cada ciclo de carga (Figura 6.4) em vez de aumentar em forma de degraus. $\mathrm{O}$ que se pretende com isto é eliminar as trincas na periferia da amostra ainda na fase de condicionamento. A sequência de carregamento proposta do Hintz (2012) consiste no mesmo número de ciclos (tempo de ensaio) e na mesma faixa de amplitudes de deformação propostos por Johnson (2010).

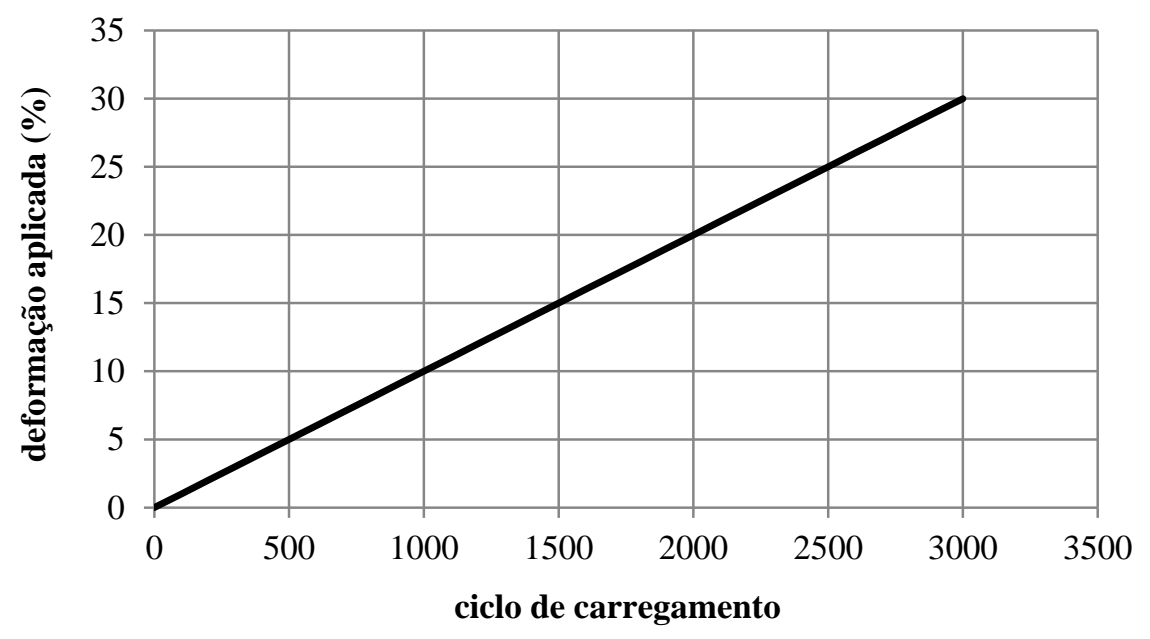

Figura 6.4 - Incremento linear de deformação no ensaio LAS modificado (HINTZ, 2012)

A Figura 6.5 apresenta a correlação entre os resultados obtidos por Hintz (2012) por meio dos ensaios LAS modificado $\left(\mathrm{a}_{\mathrm{f}}\right)$ e time sweep $\left(\mathrm{N}_{\mathrm{f}}\right)$. A autora observou que, de um modo geral, o critério de ruptura adotado no LAS modificado $\left(\mathrm{a}_{\mathrm{f}}\right)$ apresenta boa correlação com o critério de ruptura adotado no time sweep $\left(\mathrm{N}_{\mathrm{f}}\right)$, tanto para ligantes asfálticos puros como para ligantes asfálticos modificados com diferentes tipos de polímeros.

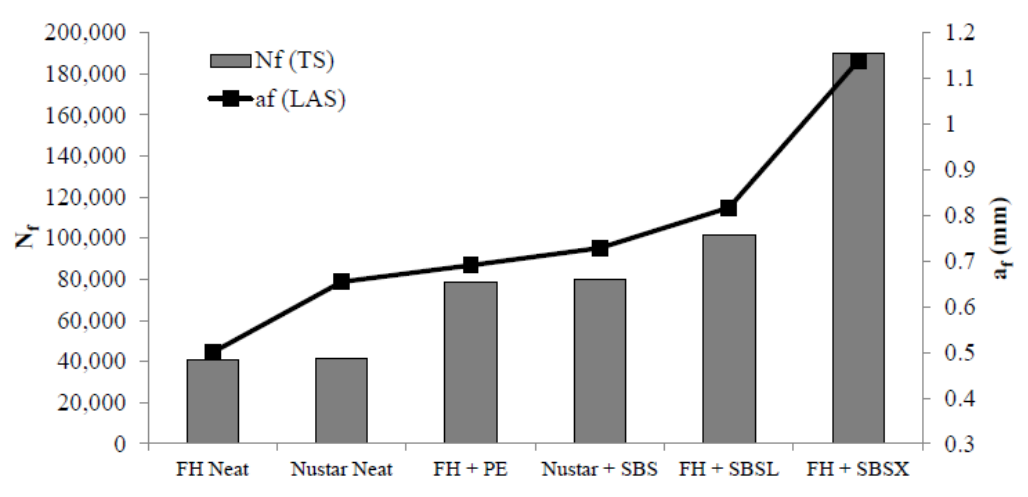

Figura 6.5 - Correlação entre resultados do LAS modificado e do time sweep (HINTZ, 2012) 


\subsection{ANÁLISE DE RESULTADOS}

Os resultados do ensaio LAS modificado foram analisados baseados no modelo de fratura, uma vez que sabe-se que há uma propagação de trincas que reduzem efetivamente o raio efetivo da amostra. Essas variações na geometria da amostra devido à propagação de trincas são responsáveis pela aparente mudança na capacidade de carregamento das amostras durante o ensaio. O critério de ruptura proposto por Hintz (2012) para analisar os resultados obtidos por meio do ensaio LAS modificado é baseado no ponto mínimo da taxa de crescimento da trinca $\left(\mathrm{a}_{\mathrm{f}}\right)$ anterior à fase de rápido aumento na taxa de crescimento da trinca. As Figuras 6.6 e 6.7 mostram a variação do crescimento da trinca em função do número de ciclos versus o comprimento da trinca do LUBNOR puro e modificados testada sob o procedimento do LAS modificado, a $25^{\circ} \mathrm{C}$, nas condições de envelhecimento a curto e longo prazo respectivamente.

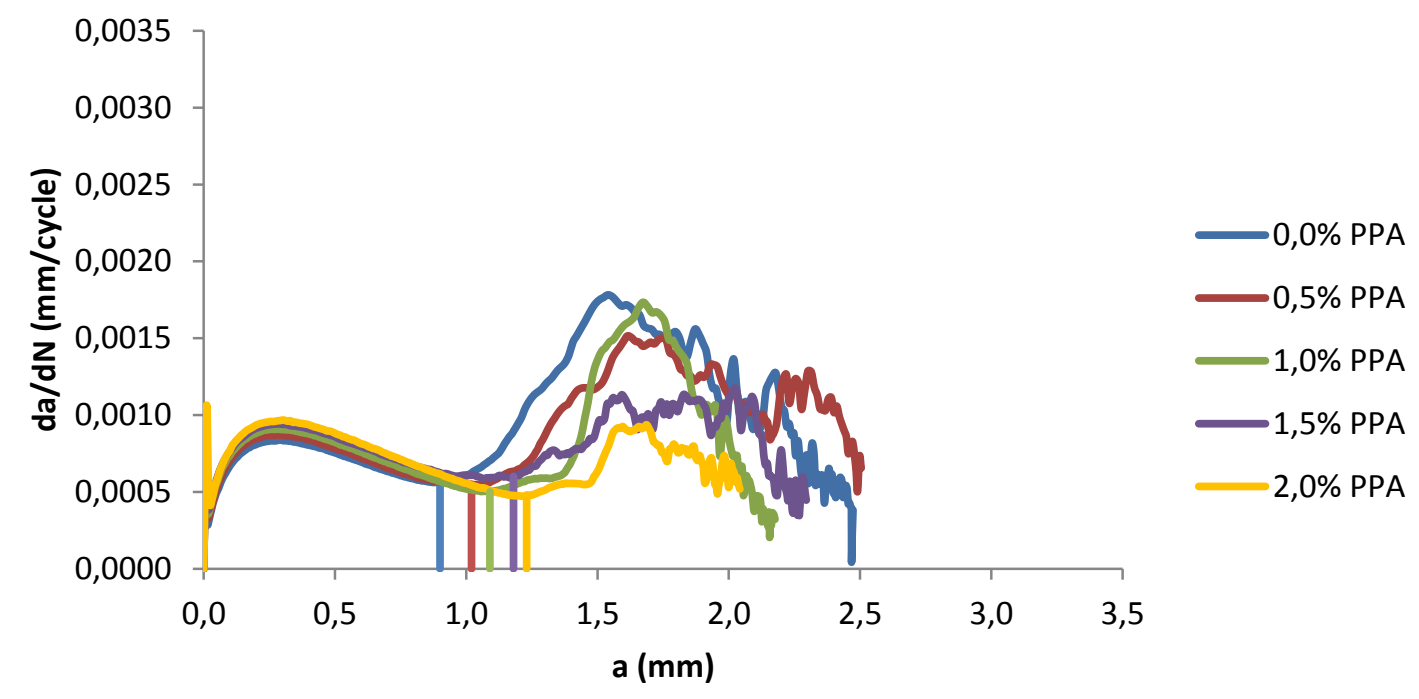

Figura 6.6 - Variação do aumento da trinca em função do número de ciclos versus o comprimento da trinca para o LUBNOR envelhecido no PAV, a $25^{\circ} \mathrm{C}$

As Figuras 6.8 e 6.9 mostram o mesmo resultado, a $25^{\circ} \mathrm{C}$, para o REDUC puro e modificados, envelhecidos a curto e longo prazo respectivamente. As Figuras 6.10 e 6.11 apresentam o mesmo resultado, a $35^{\circ} \mathrm{C}$, do LUBNOR puro e modificado, nas condições de envelhecimento a curto e longo prazo respectivamente e as Figuras 6.12 e 6.13 apresentam este resultado, a $35^{\circ} \mathrm{C}$, do REDUC puro e modificado, envelhecidos a curto e longo prazo respectivamente. Este valor mínimo $\left(\mathrm{a}_{\mathrm{f}}\right)$ é um critério de ruptura lógico, uma vez que indica o 
começo da ruptura instável e rápida da amostra e coincide aproximadamente com o início da redução da resistência ao carregamento.

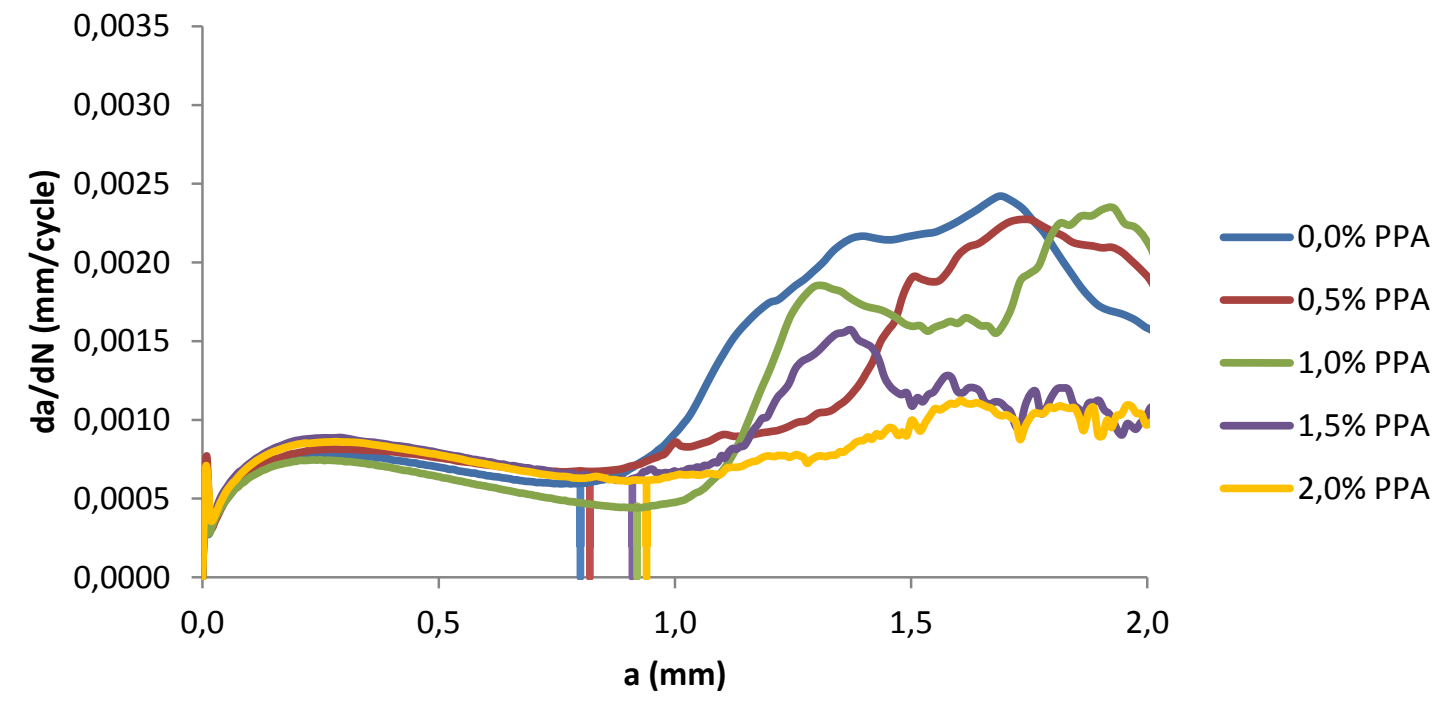

Figura 6.7 - Variação do aumento da trinca em função do número de ciclos versus o comprimento da trinca para o LUBNOR envelhecido no RTFOT, a $25^{\circ} \mathrm{C}$

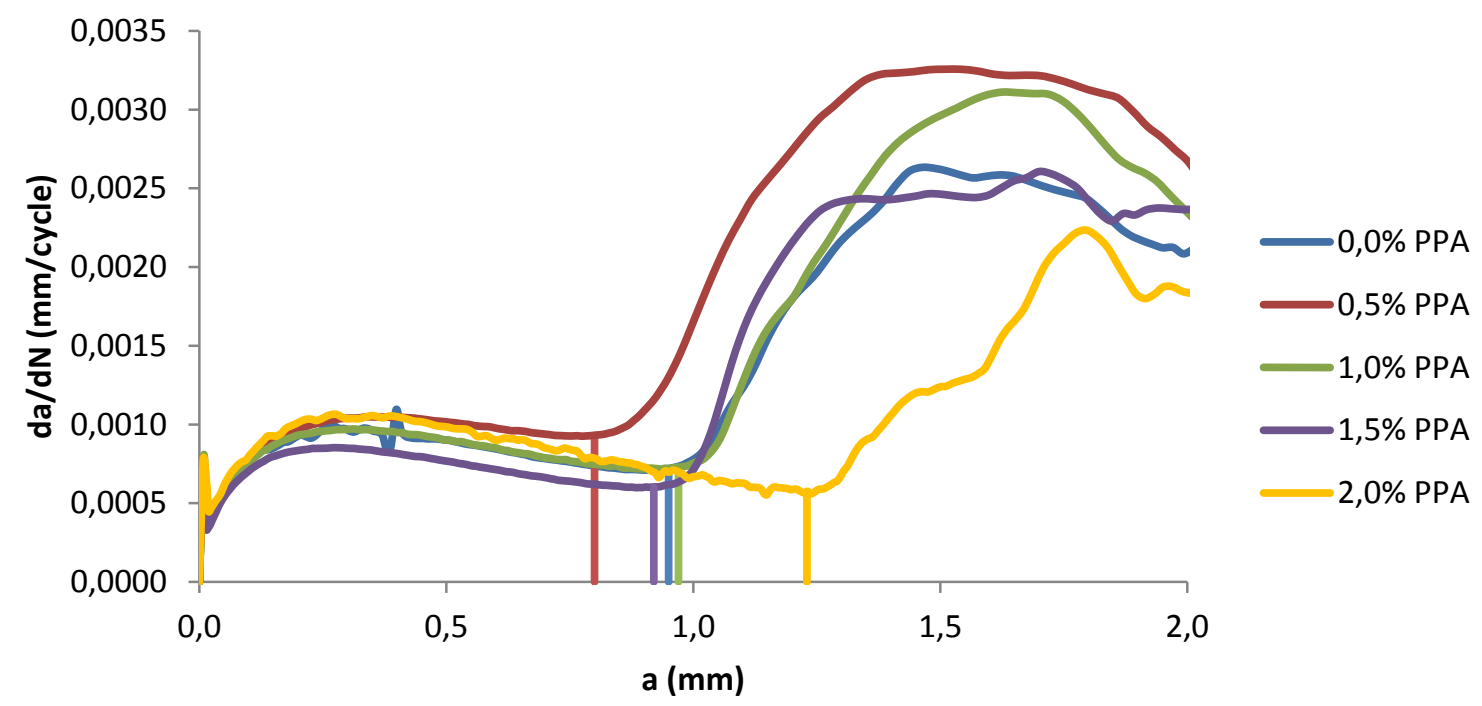

Figura 6.8 - Variação do aumento da trinca em função do número de ciclos versus o comprimento da trinca para o REDUC envelhecido no PAV, a $25^{\circ} \mathrm{C}$

De acordo com as Figuras 6.6 a 6.13, pode-se observar que, em geral, os ligantes asfálticos se tornam mais tolerantes às trincas por fadiga com a adição de PPA para estes níveis de deformação. Desta forma, o aumento de rigidez provocado pela adição de PPA é 
benéfico à resistência à trinca por fadiga. No entanto, a sensibilidade dos ligantes asfálticos à adição de PPA em termos de tolerância à fadiga é diferente para os dois tipos de ligantes asfálticos. Para o REDUC envelhecido no PAV, a adição de $0,5 \%$ de PPA é prejudicial à tolerância à fadiga nas duas temperaturas $\left(25\right.$ e $\left.35^{\circ} \mathrm{C}\right)$. A tolerância à fadiga dos ligantes asfálticos é maior na temperatura mais baixa uma vez que o ligante asfáltico se torna mais rígido com a diminuição da temperatura.

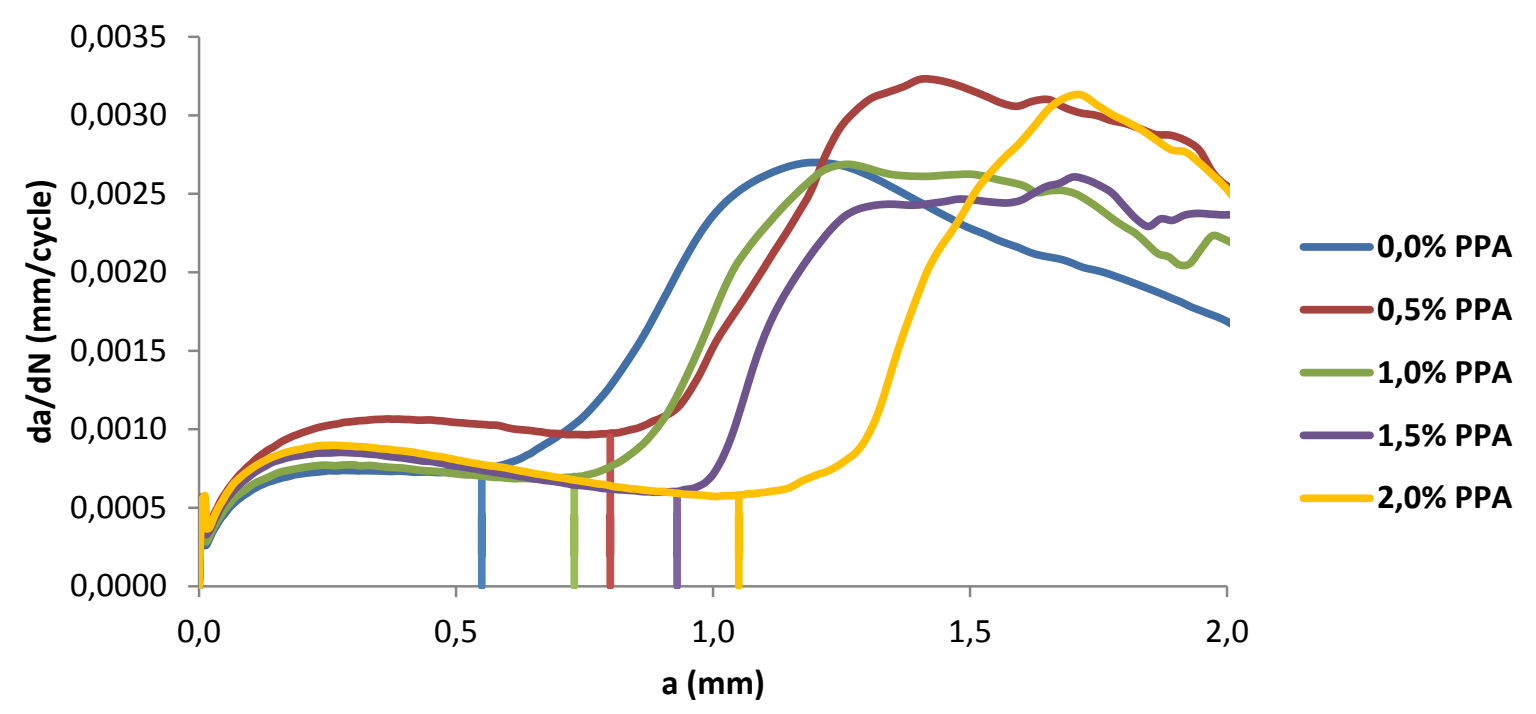

Figura 6.9 - Variação do aumento da trinca em função do número de ciclos versus o comprimento da trinca para o REDUC envelhecido no RTFOT, a $25^{\circ} \mathrm{C}$

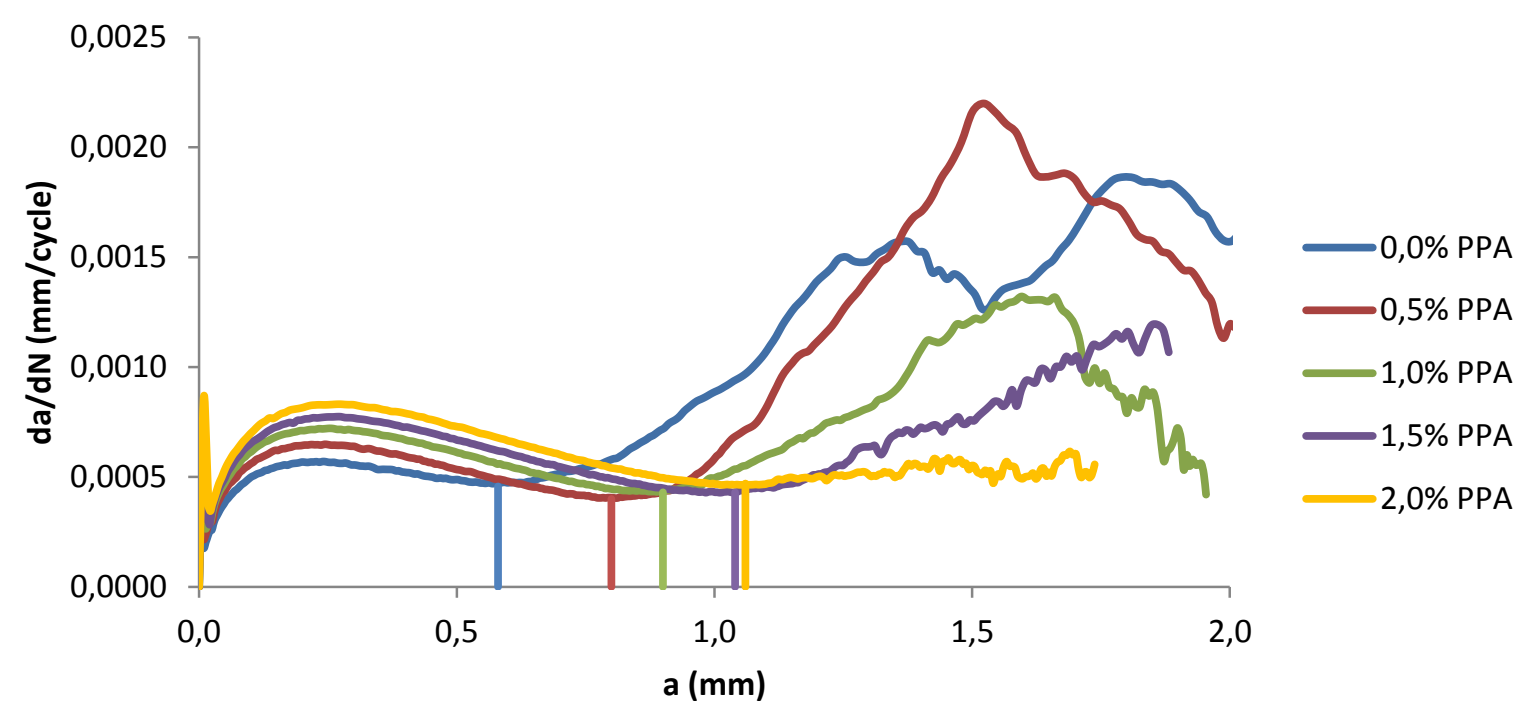

Figura 6.10 - Variação do aumento da trinca em função do número de ciclos versus o comprimento da trinca para o LUBNOR envelhecido no PAV, a $35^{\circ} \mathrm{C}$ 


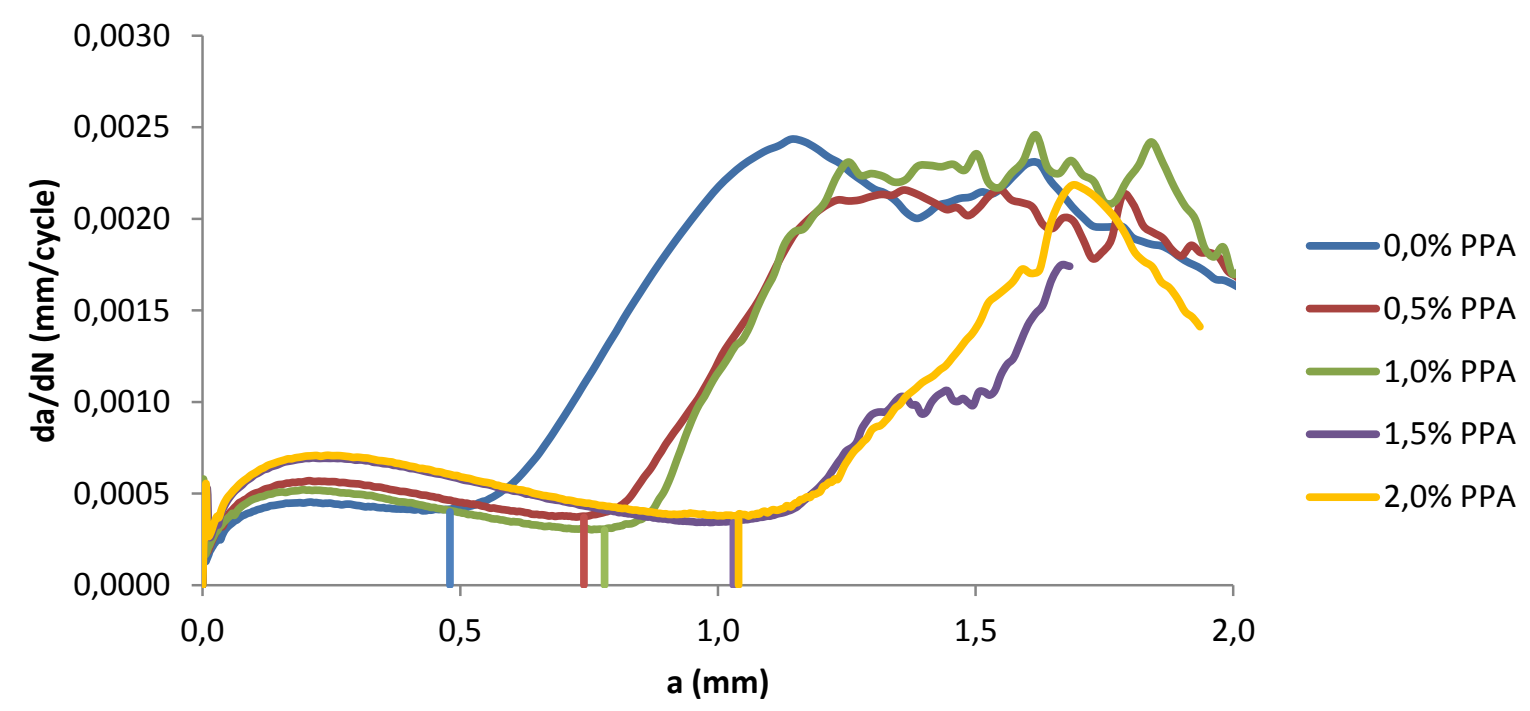

Figura 6.11 - Variação do aumento da trinca em função do número de ciclos versus o comprimento da trinca para o LUBNOR envelhecido no RTFOT, a $35^{\circ} \mathrm{C}$

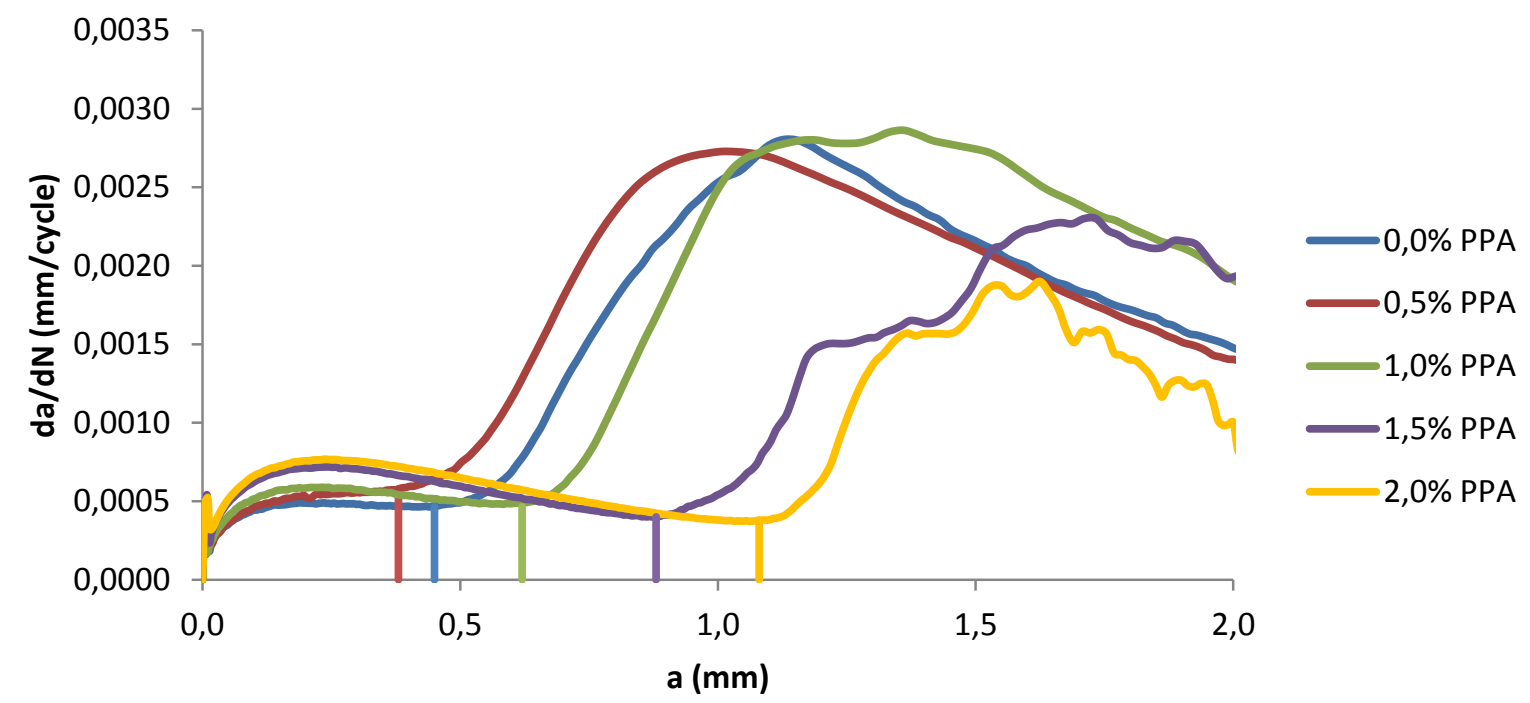

Figura 6.12 - Variação do aumento da trinca em função do número de ciclos versus o comprimento da trinca para o REDUC envelhecido no PAV aged, a $35^{\circ} \mathrm{C}$

A Tabela 6.1 apresenta o comprimento da trinca na ruptura $\left(\mathrm{a}_{\mathrm{f}}\right)$ para todos os ligantes afálticos envelhecidos no RTFO e PAV. Quanto maior for o comprimento da trinca na ruptura, mais tolerante à fadiga do ligante asfáltico é. Os resultados mostram que, para estes níveis de tensão, o envelhecimento termo-oxidativo tem um efeito positivo na tolerância à fadiga dos ligantes asfálticos, uma vez que $a_{\mathrm{f}}$ é maior para os ligantes asfálticos envelhecidos 
no PAV do que os envelhecidos no RTFOT. Para temperaturas mais elevadas, o efeito da adição de PPA é mais expressivo para os dois ligantes asfálticos, mas eles são menos tolerantes à fadiga. De acordo com os resultados, para proporções mais baixas $(0,5 \%)$, o LUBNOR é mais sensível à adição de PPA, mas para proporções mais altas (1,0\% ou mais), o REDUC é mais sensível à modificação com PPA.

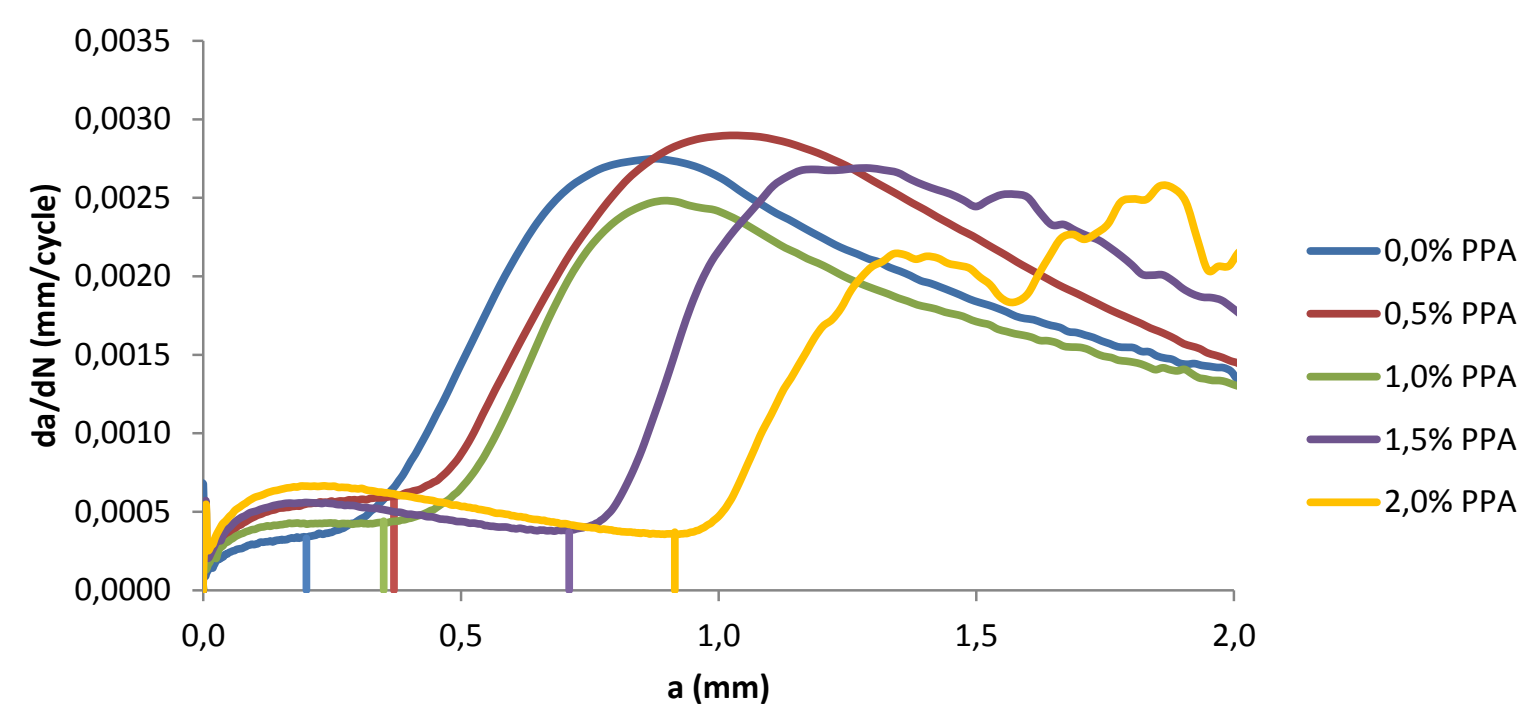

Figura 6.13 - Variação do aumento da trinca em função do número de ciclos versus o comprimento da trinca para o REDUC envelhecido no RTFOT, a $35^{\circ} \mathrm{C}$

Tabela 6.1 - Comprimento da trinca na ruptura (af) para todos os ligantes asfálticos

\begin{tabular}{ccccc|cccc}
\hline \multirow{2}{*}{} & \multicolumn{4}{c|}{$\mathbf{2 5}^{\circ} \mathbf{C}$} & \multicolumn{4}{c}{$\mathbf{3 5}^{\circ} \mathbf{C}$} \\
PPA & $\begin{array}{c}\text { LUBNOR } \\
\text { PAV }\end{array}$ & $\begin{array}{c}\text { REDUC } \\
\text { PAV }\end{array}$ & $\begin{array}{c}\text { LUBNOR } \\
\text { RTFO }\end{array}$ & $\begin{array}{c}\text { REDUC } \\
\text { RTFO }\end{array}$ & $\begin{array}{c}\text { LUBNOR } \\
\text { PAV }\end{array}$ & $\begin{array}{c}\text { REDUC } \\
\text { PAV }\end{array}$ & $\begin{array}{c}\text { LUBNOR } \\
\text { RTFO }\end{array}$ & $\begin{array}{c}\text { REDUC } \\
\text { RTFO }\end{array}$ \\
\hline $\mathbf{0 , 0}$ & 0,90 & 0,95 & 0,80 & 0,55 & 0,58 & 0,38 & 0,48 & 0,20 \\
$\mathbf{0 , 5}$ & 1,02 & 0,80 & 0,82 & 0,80 & 0,80 & 0,45 & 0,74 & 0,37 \\
$\mathbf{1 , 0}$ & 1,09 & 0,97 & 0,92 & 0,73 & 0,90 & 0,62 & 0,78 & 0,35 \\
$\mathbf{1 , 5}$ & 1,18 & 0,92 & 0,91 & 0,93 & 1,04 & 0,88 & 1,03 & 0,71 \\
$\mathbf{2 , 0}$ & 1,23 & 1,23 & 0,94 & 1,05 & 1,06 & 1,08 & 1,04 & 0,92 \\
\hline
\end{tabular}

Os parâmetros do modelo de fadiga $\mathrm{A}_{35}$ e $\mathrm{B}$ do modelo de fadiga (Figura 6.2), obtidos a partir da análise VECD dos resultados do ensaio LAS modificado estão apresentados na Tabela 6.2 e 6.3 respectivamente. Os valores de $A_{35}$ e $B$ são os valores médios das réplicas para todos os ligantes asfálticos. Os resultados mostram que o parâmetro $\mathrm{A}_{35}$ aumenta com a adição de PPA enquanto o parâmetro $\mathrm{B}$ diminui. Variações nos parâmetros $\mathrm{A}_{35} \mathrm{e} \mathrm{B}$ devido à 
adição de PPA atuam em direção oposta com respeito ao impacto da adição de PPA na tolerância à fadiga dos ligantes asfálticos.

Tabela 6.2 - Parâmetro A35 para todos os ligantes asfálticos

\begin{tabular}{ccccc|cccc}
\hline \multirow{2}{*}{} & \multicolumn{3}{c}{$\mathbf{2 5}^{\circ} \mathbf{C}$} & \multicolumn{4}{c}{$\mathbf{3 5}^{\circ} \mathbf{C}$} \\
PPA & $\begin{array}{c}\text { LUBNOR } \\
\text { PAV }\end{array}$ & $\begin{array}{c}\text { REDUC } \\
\text { PAV }\end{array}$ & $\begin{array}{c}\text { LUBNOR } \\
\text { RTFO }\end{array}$ & $\begin{array}{c}\text { REDUC } \\
\text { RTFO }\end{array}$ & $\begin{array}{c}\text { LUBNOR } \\
\text { PAV }\end{array}$ & $\begin{array}{c}\text { REDUC } \\
\text { PAV }\end{array}$ & $\begin{array}{c}\text { LUBNOR } \\
\text { RTFO }\end{array}$ & $\begin{array}{c}\text { REDUC } \\
\text { RTFO }\end{array}$ \\
\hline $\mathbf{0 , 0}$ & $4,82.10^{7}$ & $5,66.10^{6}$ & $1,43.10^{7}$ & $1.77 .10^{6}$ & $9,74.10^{6}$ & $2,58.10^{6}$ & $6,28.10^{6}$ & $2,00.10^{6}$ \\
$\mathbf{0 , 5}$ & $1,23.10^{8}$ & $2,01.10^{6}$ & $5,29.10^{7}$ & $1.51 .10^{6}$ & $6,28.10^{6}$ & $1,59.10^{6}$ & $1,06.10^{7}$ & $1,67.10^{6}$ \\
$\mathbf{1 , 0}$ & $7,40.10^{8}$ & $9,62.10^{6}$ & $4,70.10^{7}$ & $3.43 .10^{6}$ & $6,32.10^{7}$ & $1,80.10^{6}$ & $7,10.10^{6}$ & $2,84.10^{6}$ \\
$\mathbf{1 , 5}$ & $6,34.10^{8}$ & $6,35.10^{7}$ & $7,54.10^{8}$ & $1.47 .10^{7}$ & $1,82.10^{8}$ & $2,17.10^{7}$ & $6,50.10^{7}$ & $1,99.10^{7}$ \\
$\mathbf{2 , 0}$ & $6,12.10^{9}$ & $4,18.10^{8}$ & $5,03.10^{8}$ & $6,84.10^{7}$ & $1,55.10^{9}$ & $9,57.10^{7}$ & $4,95.10^{7}$ & $6,94.10^{6}$ \\
\hline
\end{tabular}

Tabela 6.3 - Parâmetro B para todos os ligantes asfálticos

\begin{tabular}{ccccc|cccc}
\hline $\mathbf{\%}$ & \multicolumn{4}{c}{$\mathbf{2 5}^{\circ} \mathbf{C}$} & \multicolumn{4}{c}{$\mathbf{3 5}^{\circ} \mathbf{C}$} \\
PPA & $\begin{array}{c}\text { LUBNOR } \\
\text { PAV }\end{array}$ & $\begin{array}{c}\text { REDUC } \\
\text { PAV }\end{array}$ & $\begin{array}{c}\text { LUBNOR } \\
\text { RTFO }\end{array}$ & $\begin{array}{c}\text { REDUC } \\
\text { RTFO }\end{array}$ & $\begin{array}{c}\text { LUBNOR } \\
\text { PAV }\end{array}$ & $\begin{array}{c}\text { REDUC } \\
\text { PAV }\end{array}$ & $\begin{array}{c}\text { LUBNOR } \\
\text { RTFO }\end{array}$ & $\begin{array}{c}\text { REDUC } \\
\text { RTFO }\end{array}$ \\
\hline $\mathbf{0 , 0}$ & $-5,86$ & $-5,11$ & $-5,44$ & $-4,50$ & $-5,44$ & $-4,54$ & $-4,99$ & $-4,12$ \\
$\mathbf{0 , 5}$ & $-6,31$ & $-4,84$ & $-5,91$ & $-4,75$ & $-4,99$ & $-4,38$ & $-5,61$ & $-4,27$ \\
$\mathbf{1 , 0}$ & $-7,00$ & $-5,39$ & $-5,85$ & $-4,80$ & $-6,69$ & $-4,39$ & $-5,70$ & $-4,53$ \\
$\mathbf{1 , 5}$ & $-7,39$ & $-6,18$ & $-7,01$ & $-5,49$ & $-7,32$ & $-5,89$ & $-6,74$ & $-5,85$ \\
$\mathbf{2 , 0}$ & $-7,96$ & $-6,97$ & $-6,85$ & $-6,09$ & $-7,66$ & $-6,52$ & $-6,77$ & $-5,25$ \\
\hline
\end{tabular}

O parâmetro B depende exclusivamente do $\alpha$ que é obtido da inclinação do gráfico do módulo de armazenamento (G') versus a frequência, obtido a partir do ensaio de varredura de frequência. Essa diminuição do parâmetro B implica que a adição de PPA diminui a suscetibilidade ao tempo/temperatura dos ligantes asfálticos, uma vez que há uma diminuição na inclinação do gráfico de G' versus frequência. O parâmetro A é dependente da integridade do material versus dano acumulado (ex., $\left|\mathrm{G}^{*}\right|$.sen $\delta$ versus dano acumulado) e do módulo complexo inicial do ligante asfáltico ainda sem dano. É desejável obter um material que mantenha a integridade do material elevada medida através do parâmetro $\left|G^{*}\right|$.sen $\delta$. Se isto acontecer, o valor do parâmetro $A_{35}$ vai ser alto. No entanto, se o ligante asfáltico tiver uma queda rápida nos valores de $\left|\mathrm{G}^{*}\right|$.sen $\delta$, então o ligante asfáltico terá um parâmetro $\mathrm{A}_{35}$ baixo. Em termos de parâmetro $A_{35}$ e $B$, o LUBNOR apresentou valores de $A_{35}$ maiores e valores de 
B menores que o REDUC. Além disso, o LUBNOR é mais sensível à adição de PPA em termos de aumento de $\mathrm{A}_{35}$ e diminuiçao de $\mathrm{B}$.

Um modelo de fadiga para cada ligante asfáltico foi determinado utilizando o princípio de dano contínuo viscoelástico conforme indicado na Figura 6.2. Para a caracterização da fadiga em ligantes asfálticos, o modelo é derivado da relação entre a carga aplicada e a vida de fadiga do material. As Figuras 6.14 e 6.15 apresentam as vidas de fadiga $\left(\mathrm{N}_{\mathrm{f}}\right)$ do LUBNOR puro e modificados, envelhecidos no PAV e no RTFOT, respectivamente, em função da amplitude de deformação, obtidas a partir dos ensaios a $25^{\circ} \mathrm{C}$. As Figuras 6.16 e 6.17 apresentam o mesmo tipo de gráfico para o REDUC puro e modificados, envelhecidos no PAV e no RTFOT respectivamente, obtidos a partir dos ensaios a $25^{\circ} \mathrm{C}$. As Figuras $6.18 \mathrm{e}$ 6.19 apresentam o mesmo tipo de gráfico para o LUBNOR puro e modificados, envelhecidos no PAV e no RTFOT respectivamente, obtidos a partir dos ensaios a $35^{\circ} \mathrm{C}$. As Figuras $6.20 \mathrm{e}$ 6.21 apresentam o mesmo tipo de gráfico para o REDUC puro e modificados, envelhecidos no PAV e no RTFOT respectivamente, obtidos a partir dos ensaios a $35^{\circ} \mathrm{C}$.

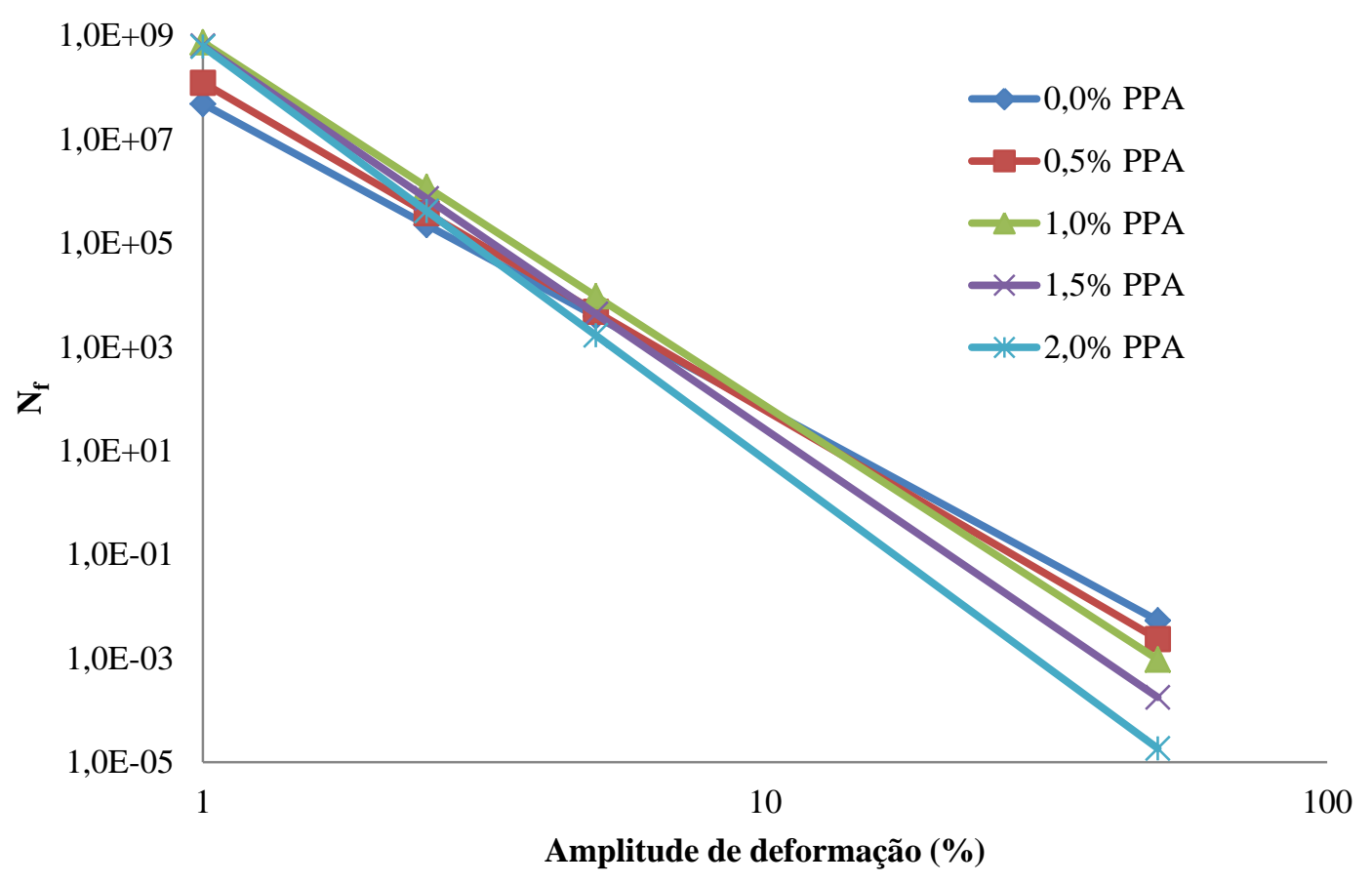

Figura 6.14 - Variação do número de ciclos na ruptura em função da amplitude de deformação para os ligantes asfálticos da LUBNOR envelhecidos no PAV, à $25^{\circ} \mathrm{C}$ 
Observa-se que a resistência à fadiga dos ligantes asfálticos é dependente do nível de tensão. Para níveis de tensão mais baixos, quanto mais rígido for o ligante asfáltico, maior será a vida de fadiga. Nessas condições, a adição de PPA é benéfica à resistência à fadiga dos ligantes asfálticos. No entanto, para níveis de tensão mais elevados, quanto mais rígido for o ligante asfáltico, menor será a vida de fadiga. Logo, o enrijecimento provocado pela adição de PPA é prejudicial à resistência à fadiga dos ligantes asfálticos.

De posse dos modelos de fadiga para cada material, é possível avaliar o efeito do nível de deformação a que estará sujeito o pavimento sobre o efeito da adição de PPA ao ligante asfáltico: a adição de PPA é favorável apenas quando o pavimento estiver sujeito a pequenas deformações (condição típica de pavimentos com comportamento deflectométrico mais próximo do rígido). Pavimentos flexíveis sujeitos a grandes deformações não seriam beneficiados pela adição de PPA ao ligante asfáltico, uma vez que se verifica redução da vida de fadiga com o aumento da proporção de PPA adicionada ao ligante asfáltico.

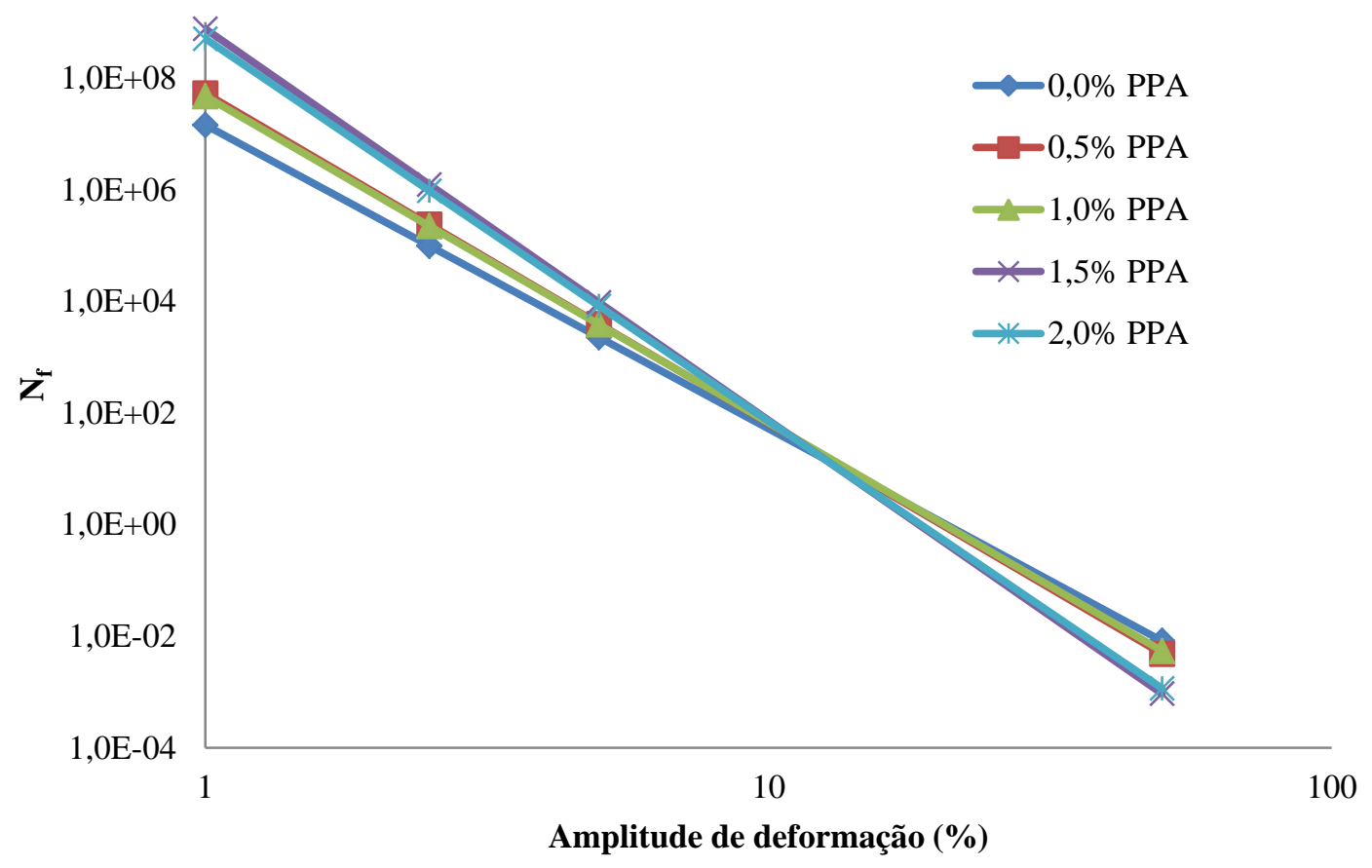

Figura 6.15 - Variação do número de ciclos na ruptura em função da amplitude de deformação para os ligantes asfálticos da LUBNOR envelhecidos no RTFOT, à $25^{\circ} \mathrm{C}$ 


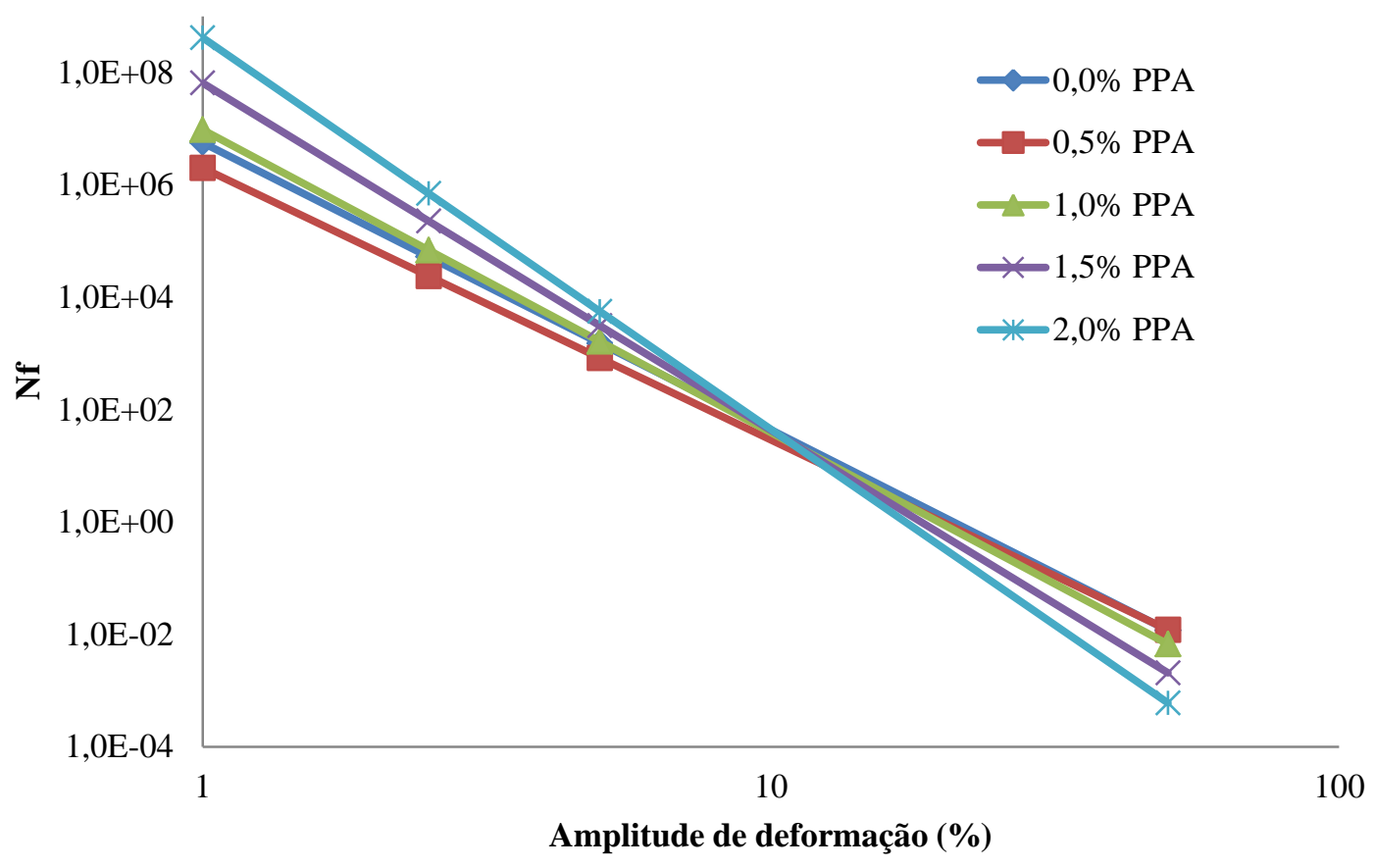

Figura 6.16 - Variação do número de ciclos na ruptura em função da amplitude de deformação para os ligantes asfálticos da REDUC envelhecidos no PAV, à $25^{\circ} \mathrm{C}$

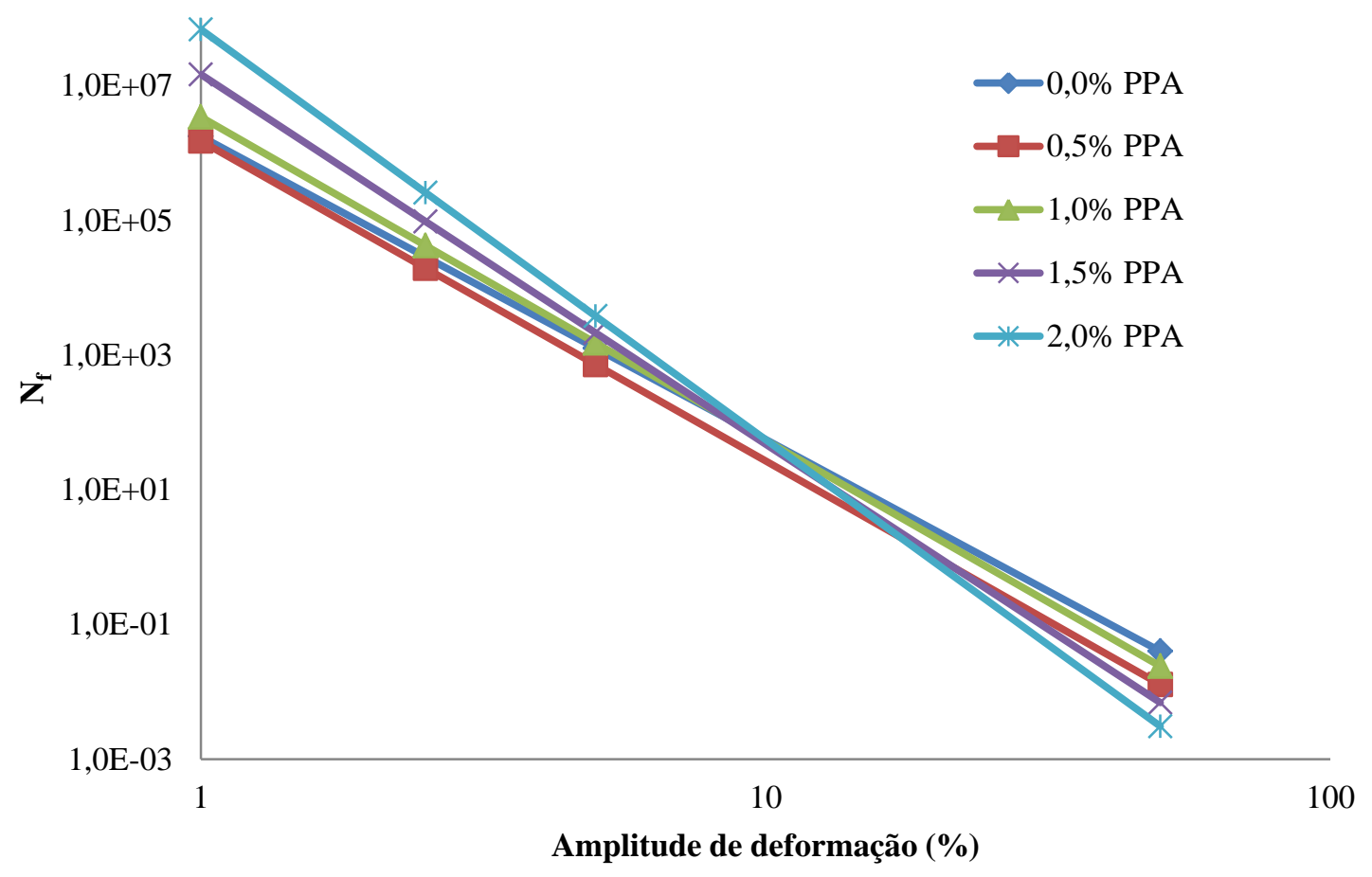

Figura 6.17 - Variação do número de ciclos na ruptura em função da amplitude de deformação para os ligantes asfálticos da REDUC envelhecidos no RTFOT, à $25^{\circ} \mathrm{C}$ 


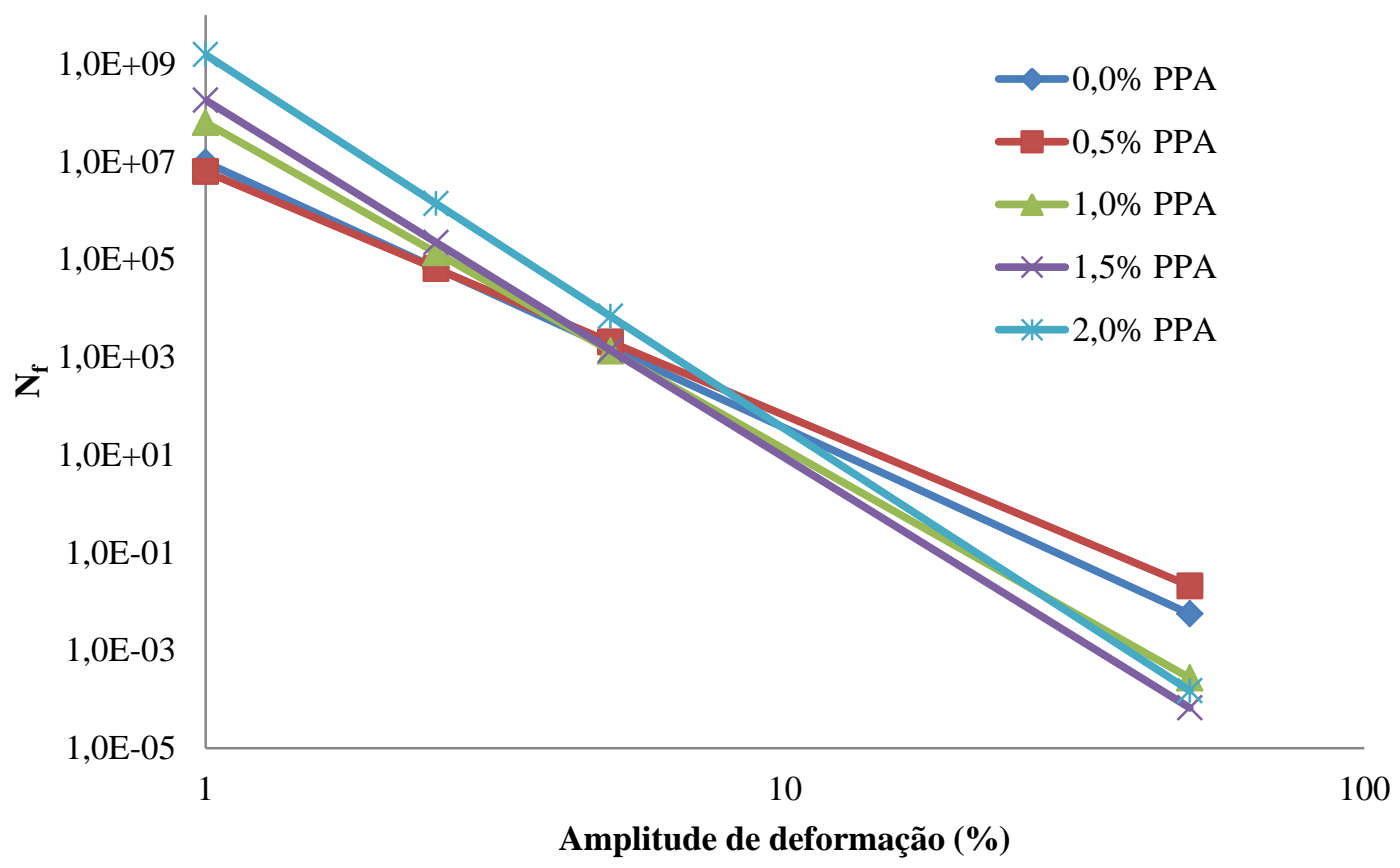

Figura 6.18 - Variação do número de ciclos na ruptura em função da amplitude de deformação para os ligantes asfálticos da LUBNOR envelhecidos no PAV, à $35^{\circ} \mathrm{C}$

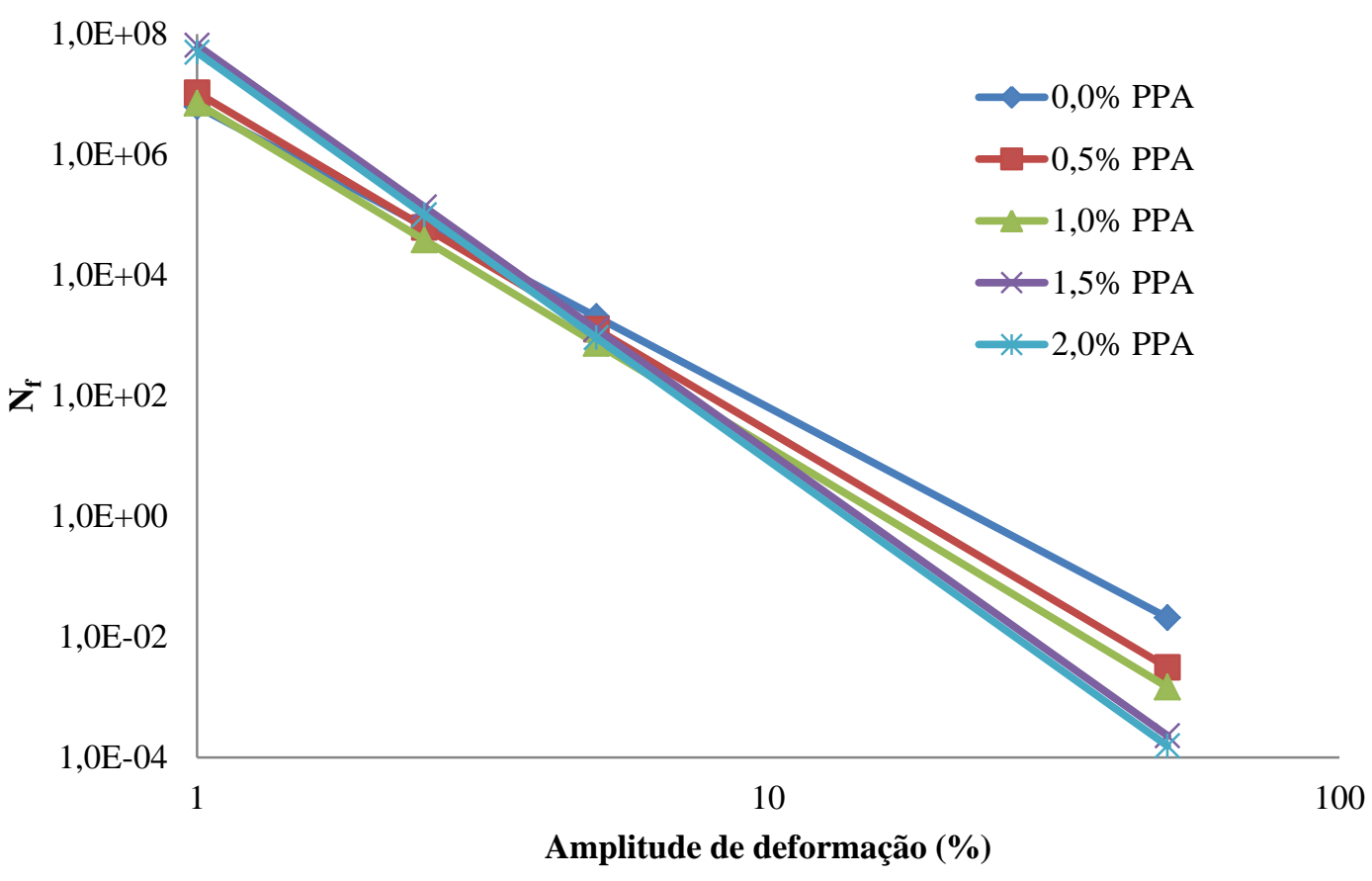

Figura 6.19 Variação do número de ciclos na ruptura em função da amplitude de deformação para os ligantes asfálticos da LUBNOR envelhecidos no RTFOT, à $35^{\circ} \mathrm{C}$ 


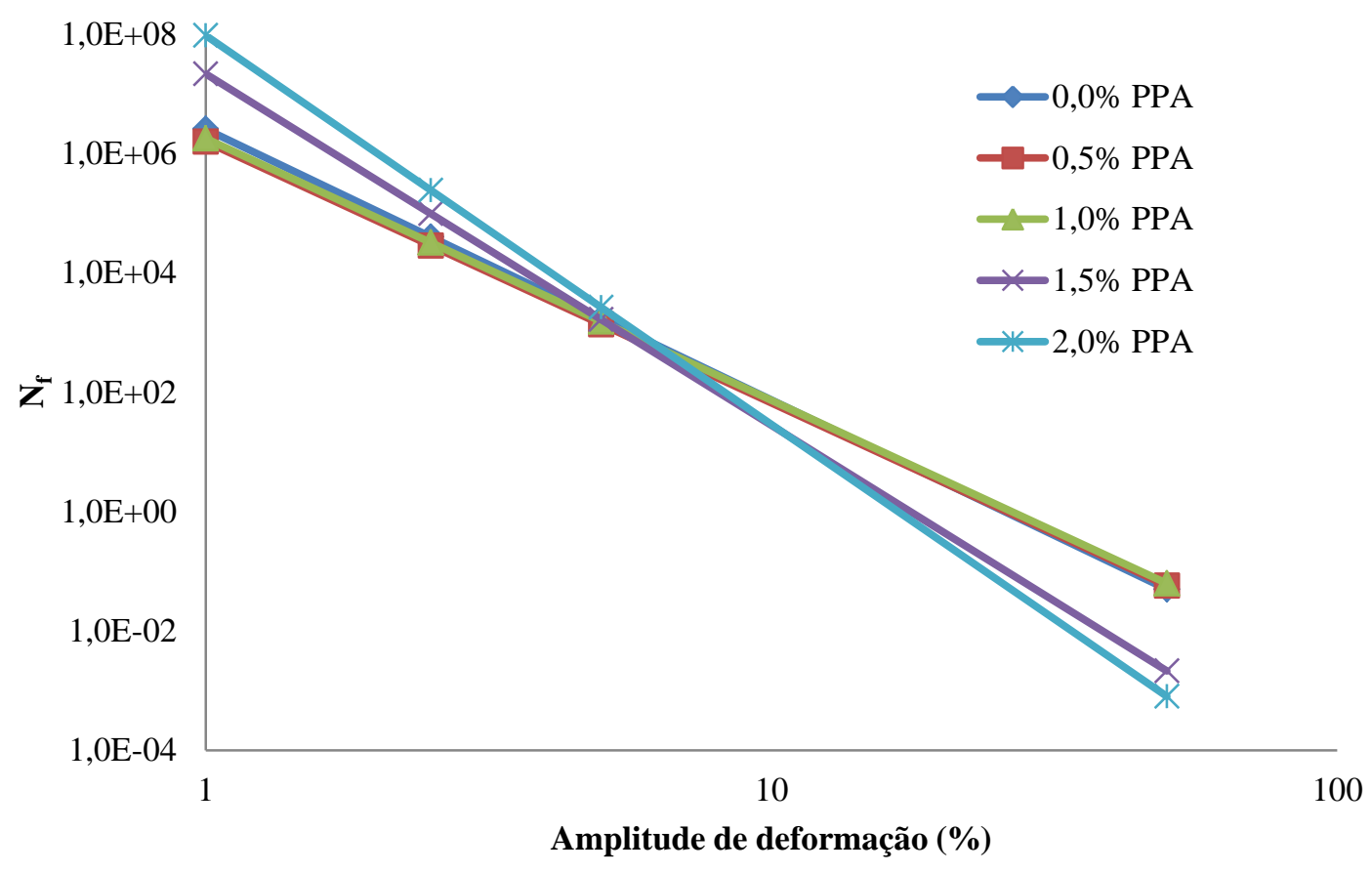

Figura 6.20 - Variação do número de ciclos na ruptura em função da amplitude de deformação para os ligantes asfálticos da REDUC envelhecidos no PAV, à $35^{\circ} \mathrm{C}$

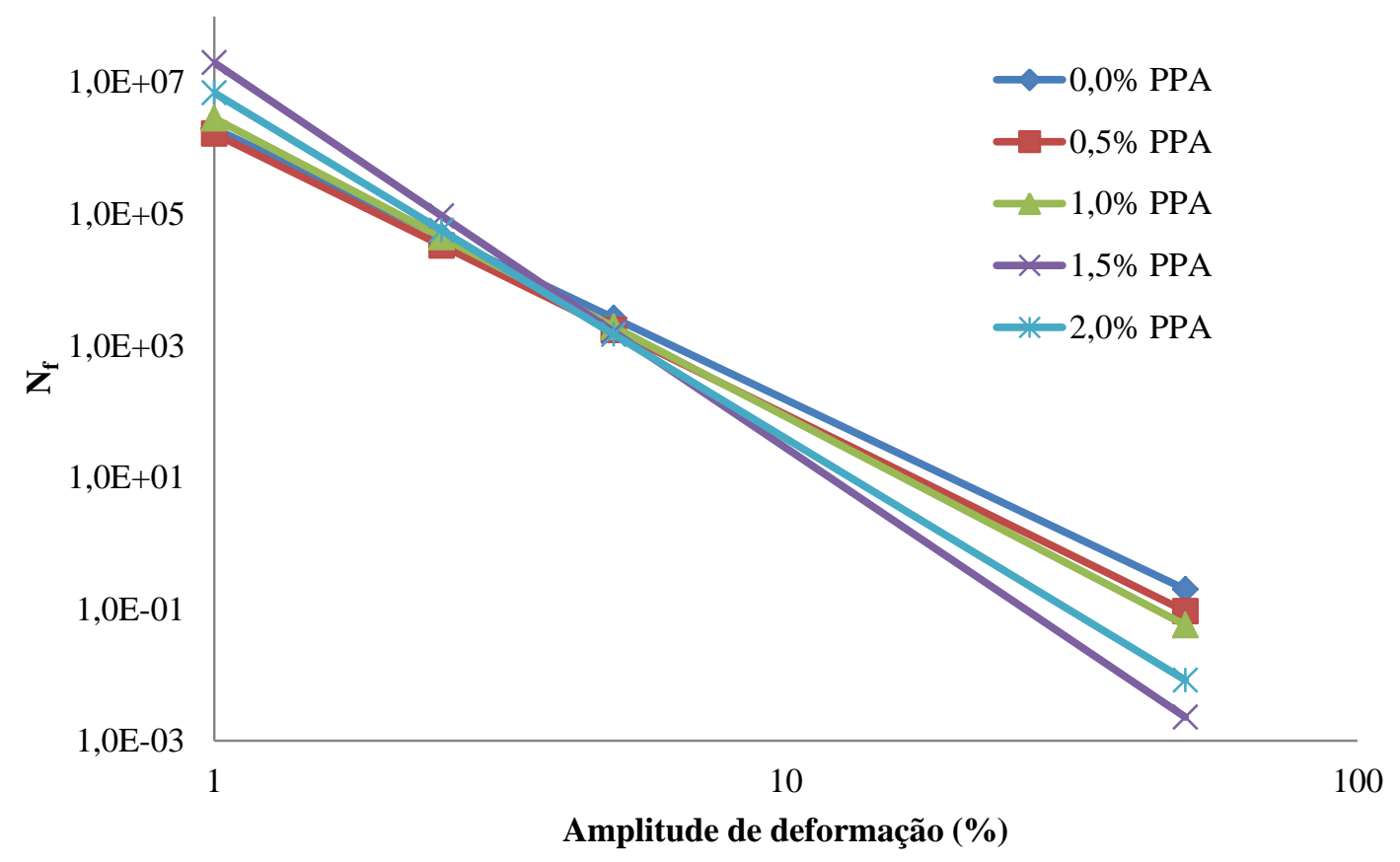

Figura 6.21 - Variação do número de ciclos na ruptura em função da amplitude de deformação para os ligantes asfálticos da REDUC envelhecidos no RTFOT, à $35^{\circ} \mathrm{C}$ 
As Figuras 6.22 a 6.26 indicam o efeito do envelhecimento oxidativo na variação do número de ciclos na ruptura em função da amplitude de deformação do LUBNOR, à $25^{\circ} \mathrm{C}$. As Figuras 6.27 a 6.31 indicam o efeito do envelhecimento oxidativo na variação do número de ciclos na ruptura em função da amplitude de deformação do REDUC, à $25^{\circ} \mathrm{C}$. As Figuras 6.32 a 6.36 apresentam a mesma análise para o LUBNOR puro e modificados à $35^{\circ} \mathrm{C}$ e as Figuras 6.37 a 6.41 apresentam a mesma análise para o REDUC puro e modificados à $35^{\circ} \mathrm{C}$.

Observa-se que, de uma maneira geral, o efeito do envelhecimento oxidativo na resistência à fadiga varia com o nível de tensão. Para níveis de tensão mais baixos, o aumento de rigidez provocado pelo envelhecimento é benéfico à resistência à fadiga, já que aumenta o número de solicitações até que ocorra falha do material. Mas para níveis de tensão mais altos, este aumento de rigidez torna-se prejudicial, pois o número de solicitações até que ocorra a falha do material diminui com o aumento do teor de PPA.

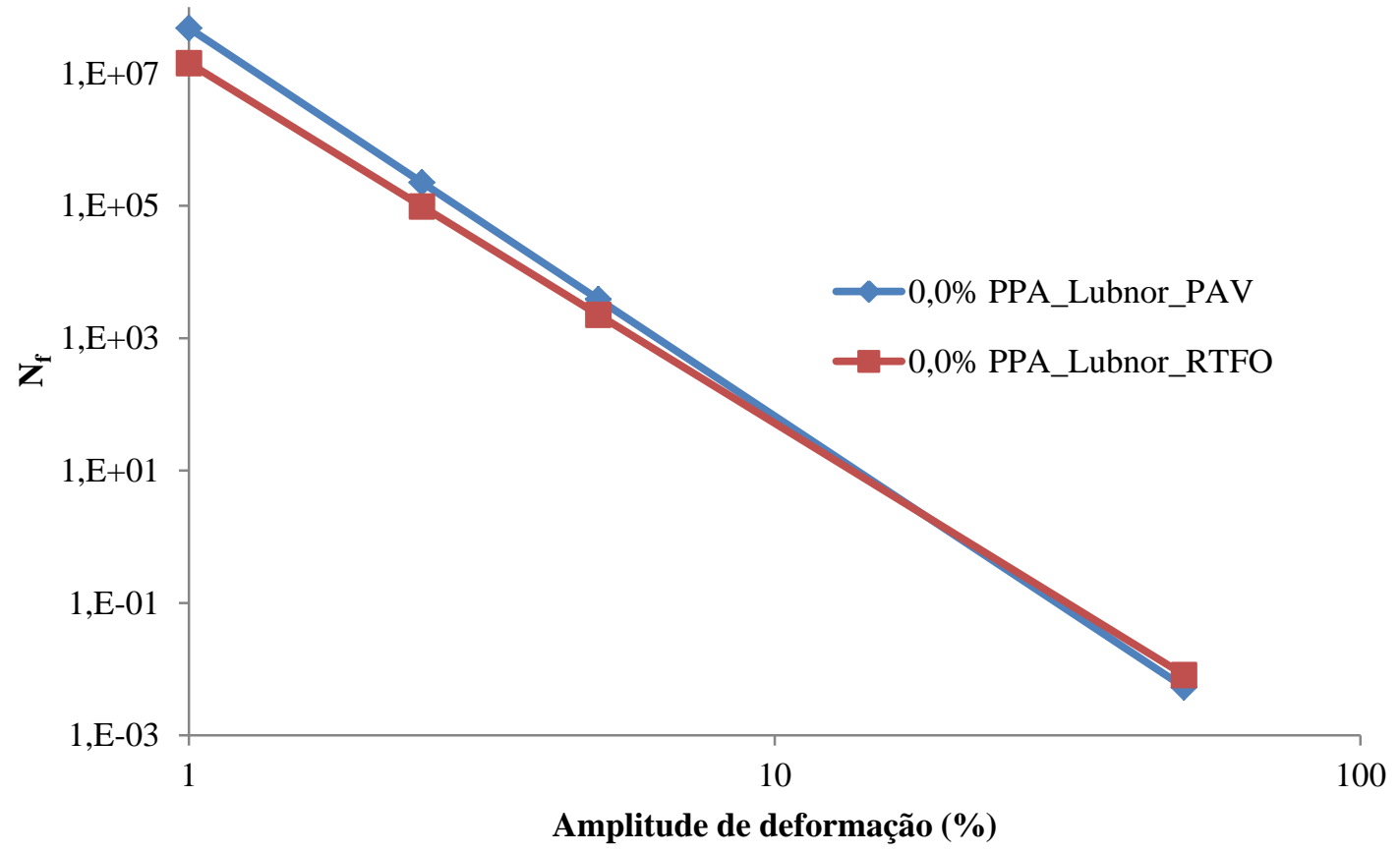

Figura 6.22 - Efeito do envelhecimento na variação do número de ciclos na ruptura em função da amplitude de deformação para o LUBNOR puro, a $25^{\circ} \mathrm{C}$ 


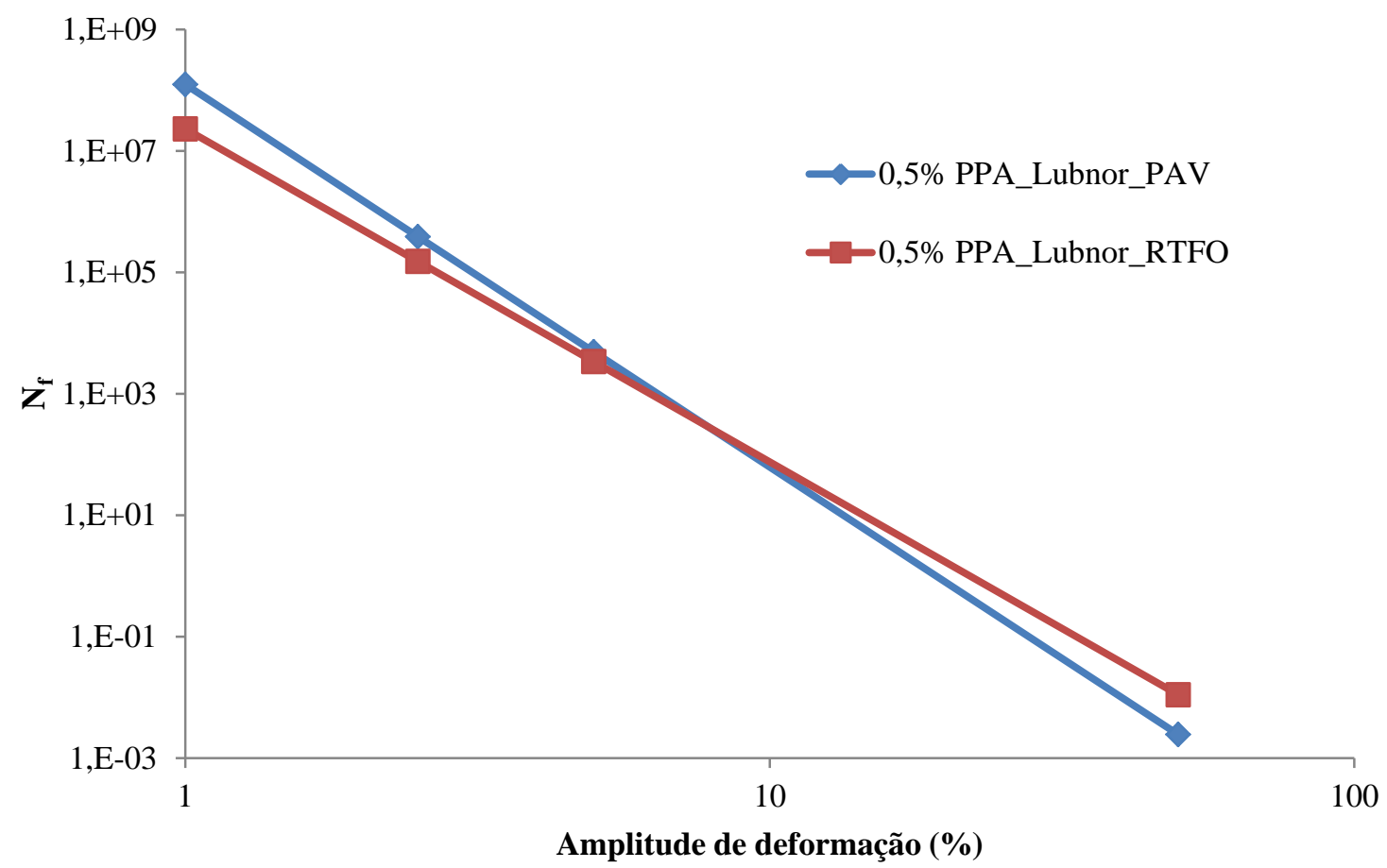

Figura 6.23 - Efeito do envelhecimento na variação do número de ciclos na ruptura em função da amplitude de deformação para o LUBNOR + 0,5\% PPA, a $25^{\circ} \mathrm{C}$

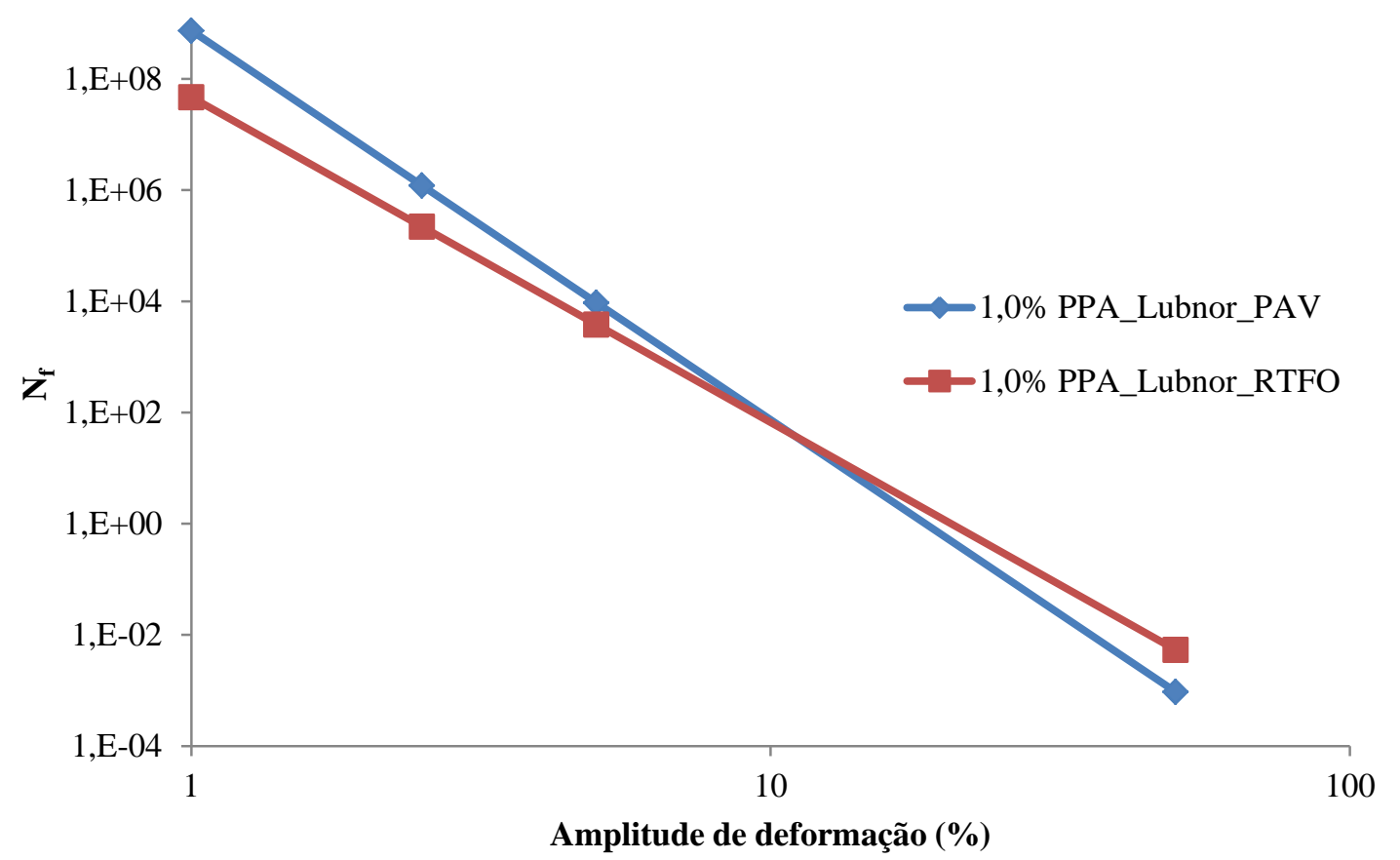

Figura 6.24 - Efeito do envelhecimento na variação do número de ciclos na ruptura em função da amplitude de deformação para o LUBNOR $+1,0 \% \mathrm{PPA}$, a $25^{\circ} \mathrm{C}$ 


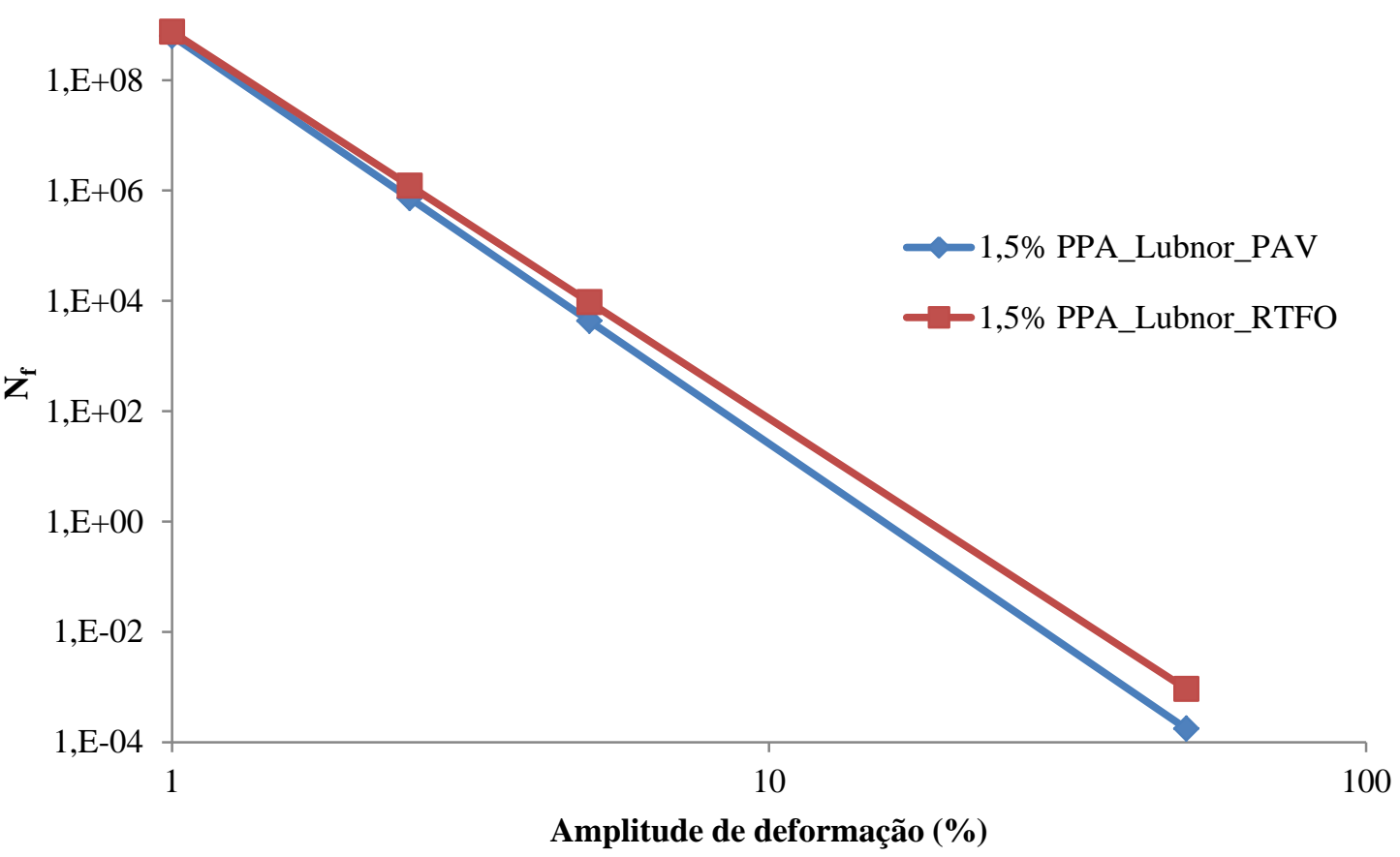

Figura 6.25 - Efeito do envelhecimento na variação do número de ciclos na ruptura em função da amplitude de deformação para o LUBNOR $+1,5 \%$ PPA, a $25^{\circ} \mathrm{C}$

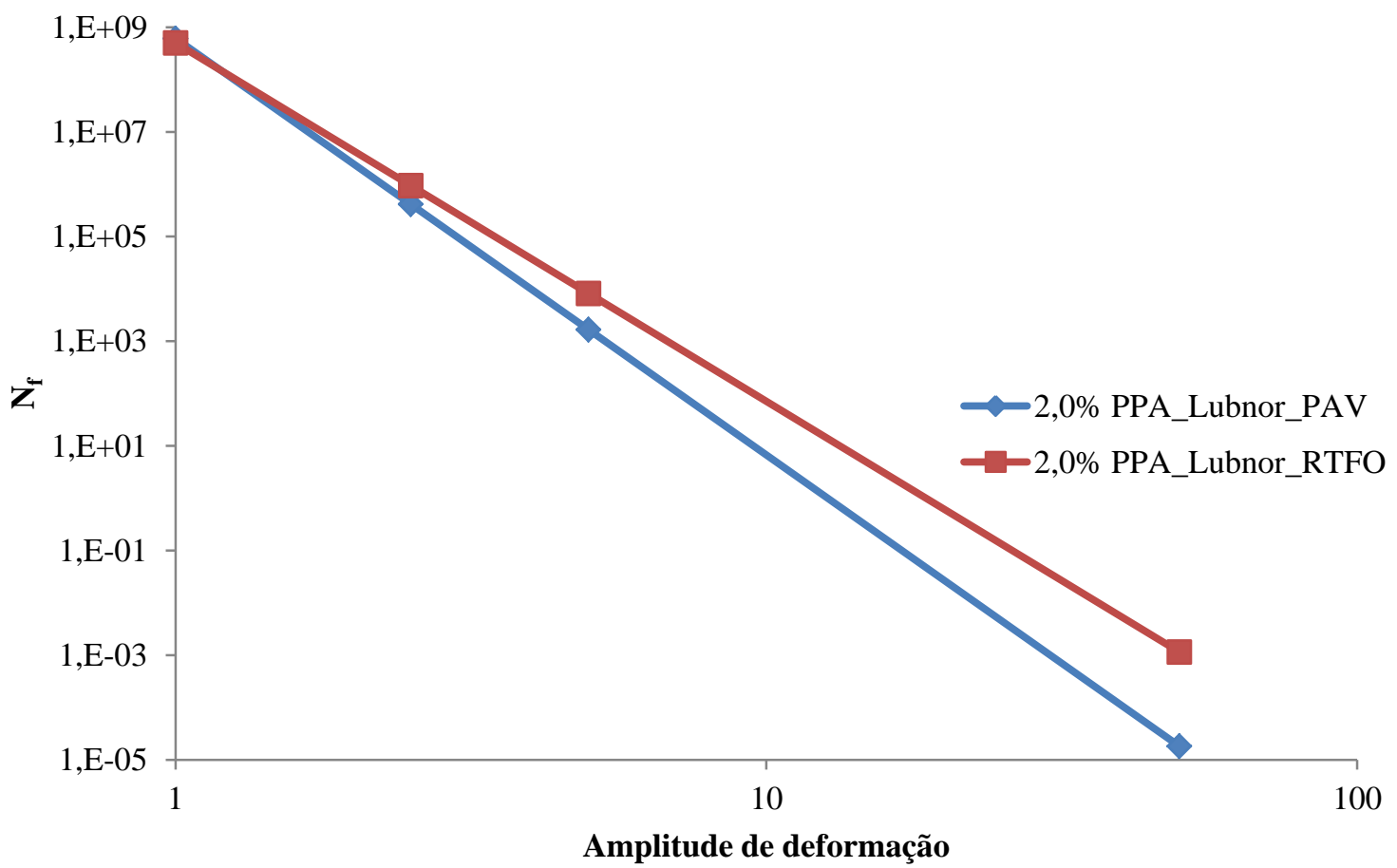

Figura 6.26 - Efeito do envelhecimento na variação do número de ciclos na ruptura em função da amplitude de deformação para o LUBNOR + 2,0\% PPA, a $25^{\circ} \mathrm{C}$ 


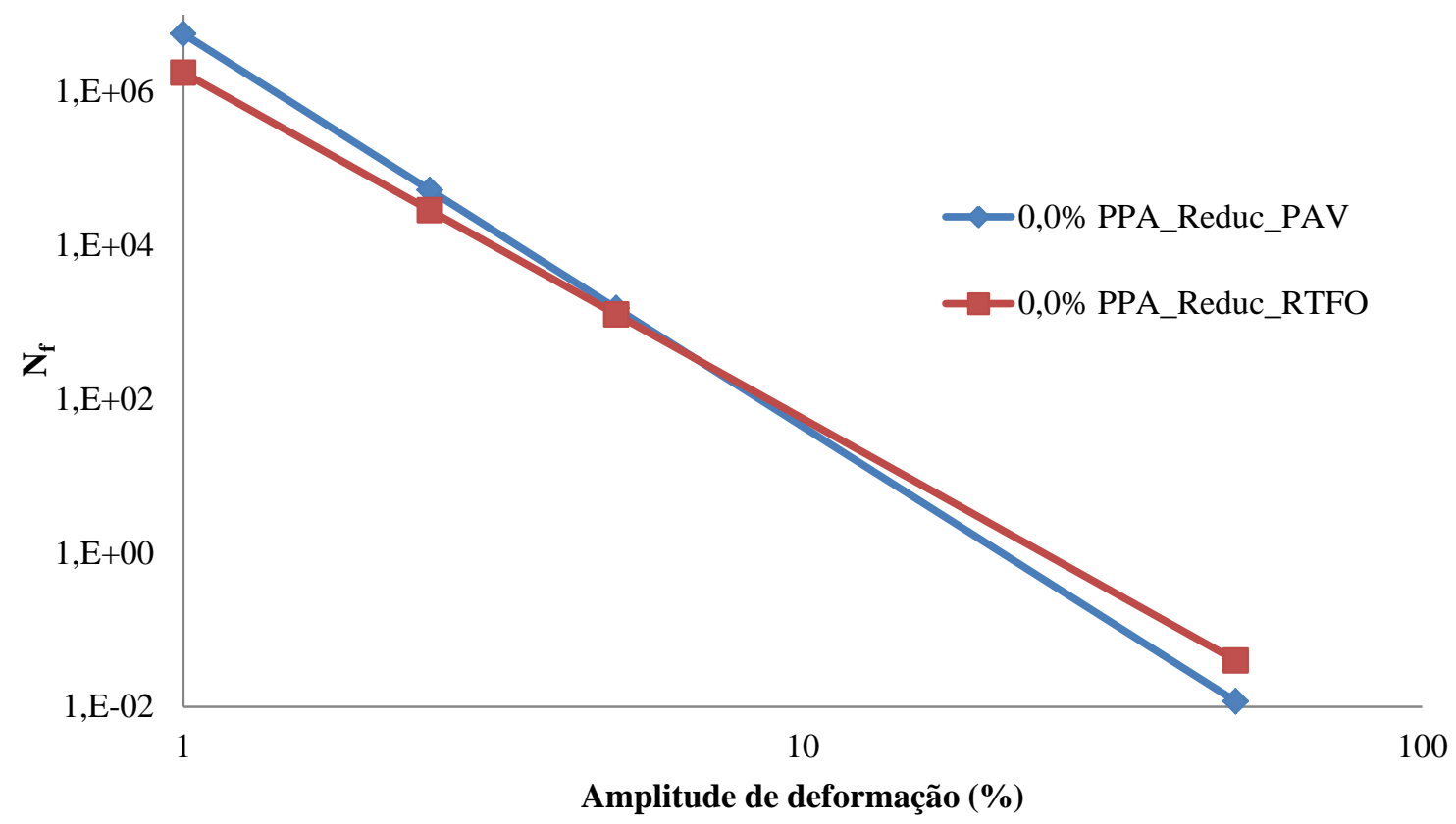

Figura 6.27 - Efeito do envelhecimento na variação do número de ciclos na ruptura em função da amplitude de deformação para o REDUC puro, a $25^{\circ} \mathrm{C}$

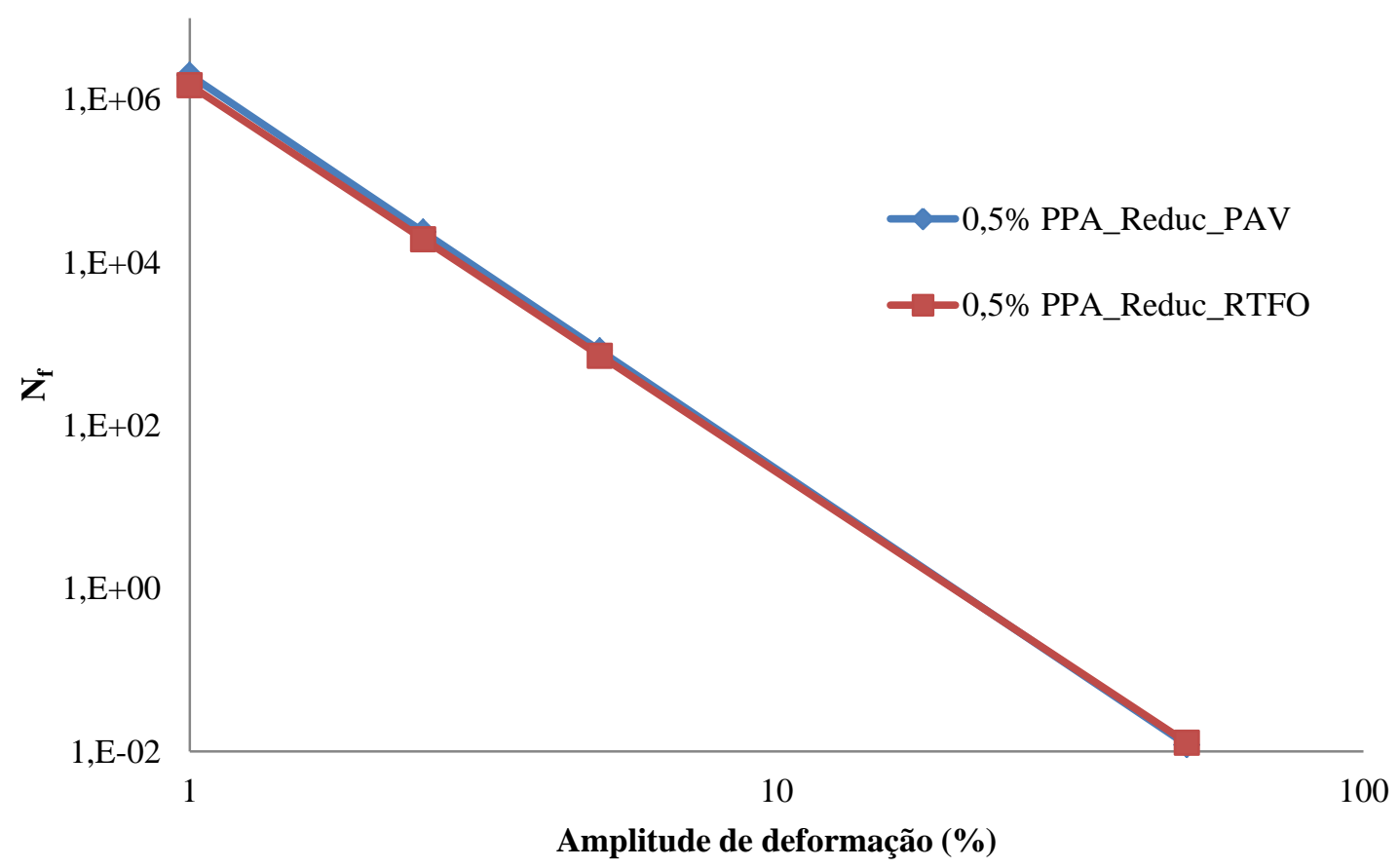

Figura 6.28 - Efeito do envelhecimento na variação do número de ciclos na ruptura em função da amplitude de deformação para o REDUC $+0,5 \%$ PPA, a $25^{\circ} \mathrm{C}$ 


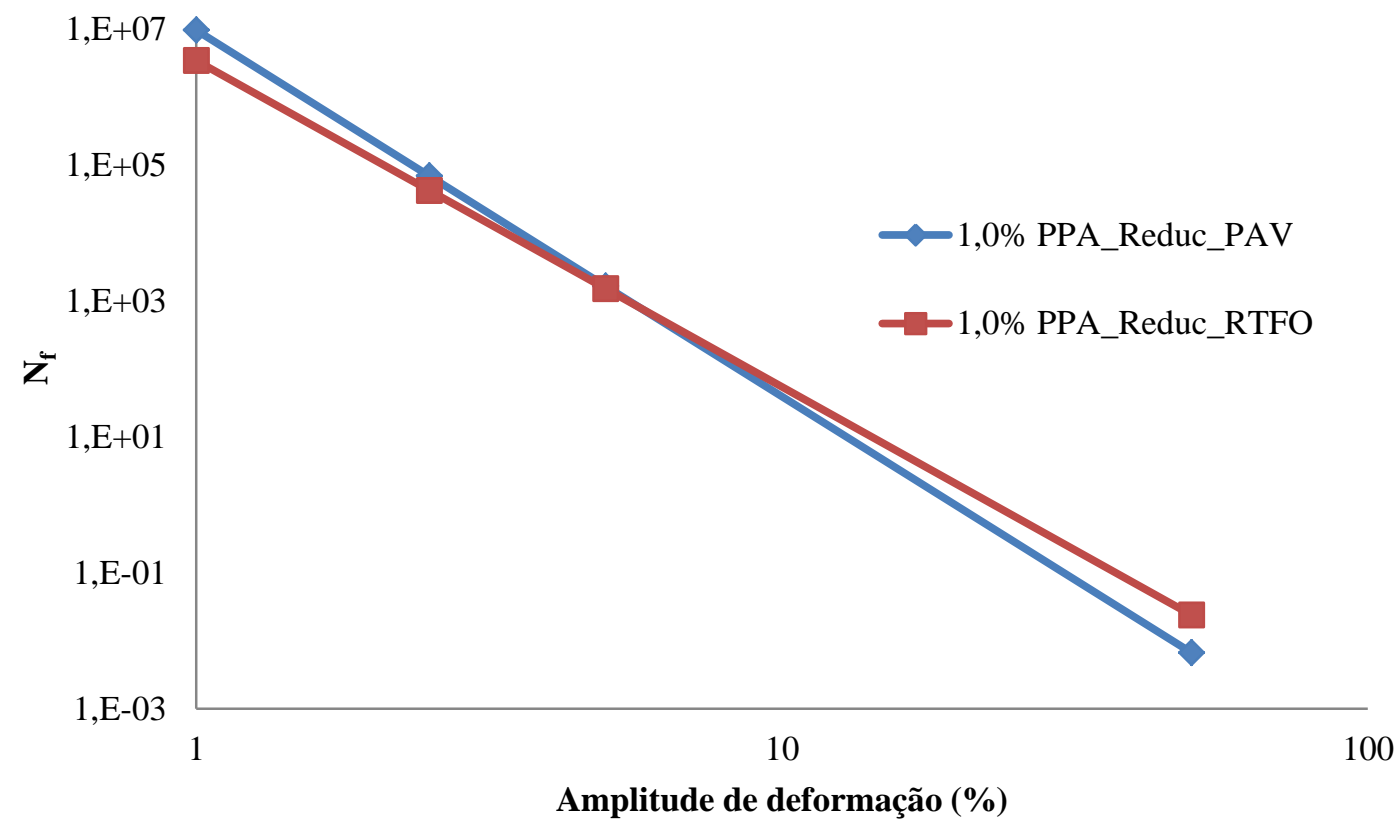

Figura 6.29 - Efeito do envelhecimento na variação do número de ciclos na ruptura em função da amplitude de deformação para o REDUC $+1,0 \% \mathrm{PPA}$, a $25^{\circ} \mathrm{C}$

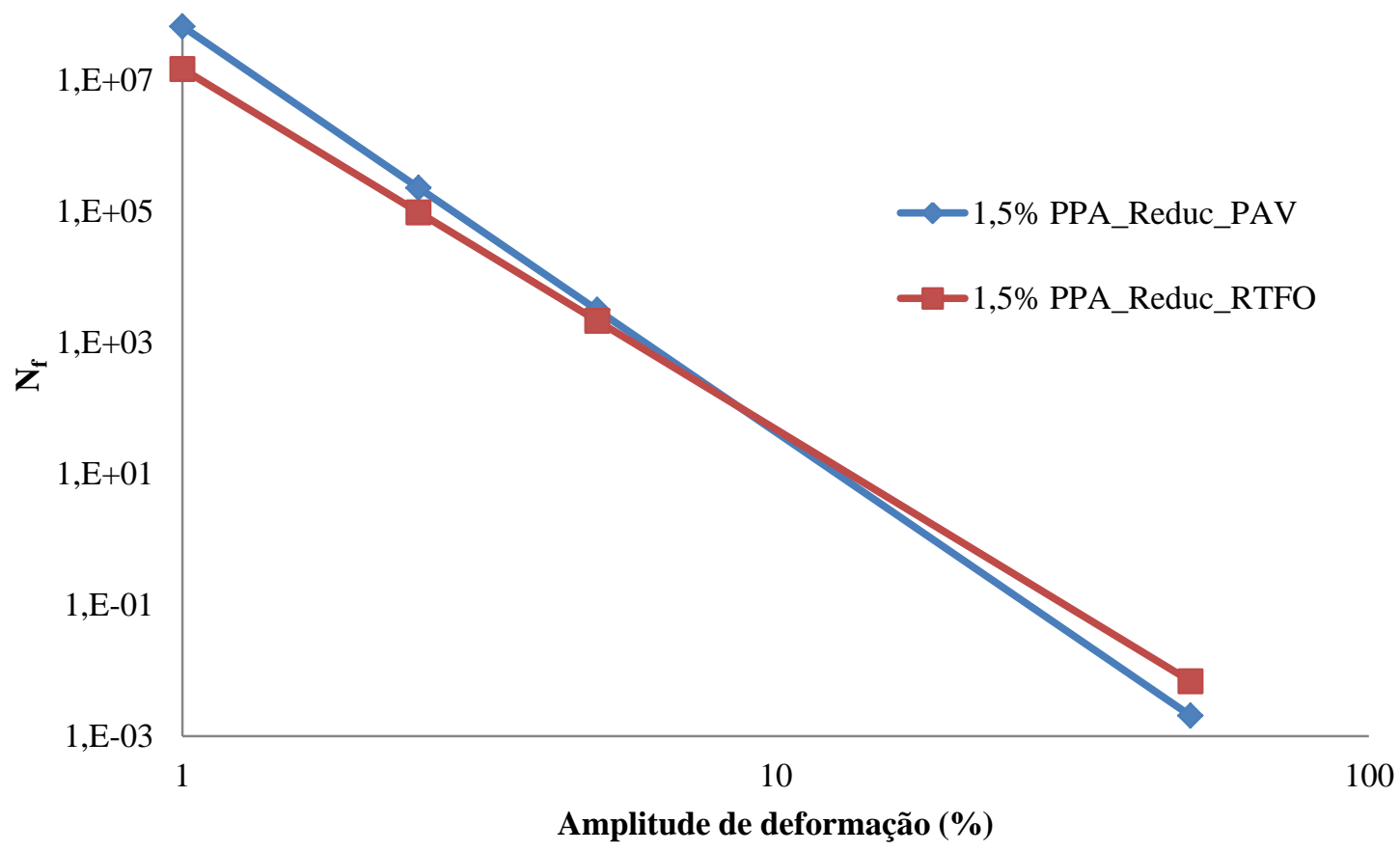

Figura 6.30 - Efeito do envelhecimento na variação do número de ciclos na ruptura em função da amplitude de deformação para o REDUC $+1,5 \%$ PPA, a $25^{\circ} \mathrm{C}$ 


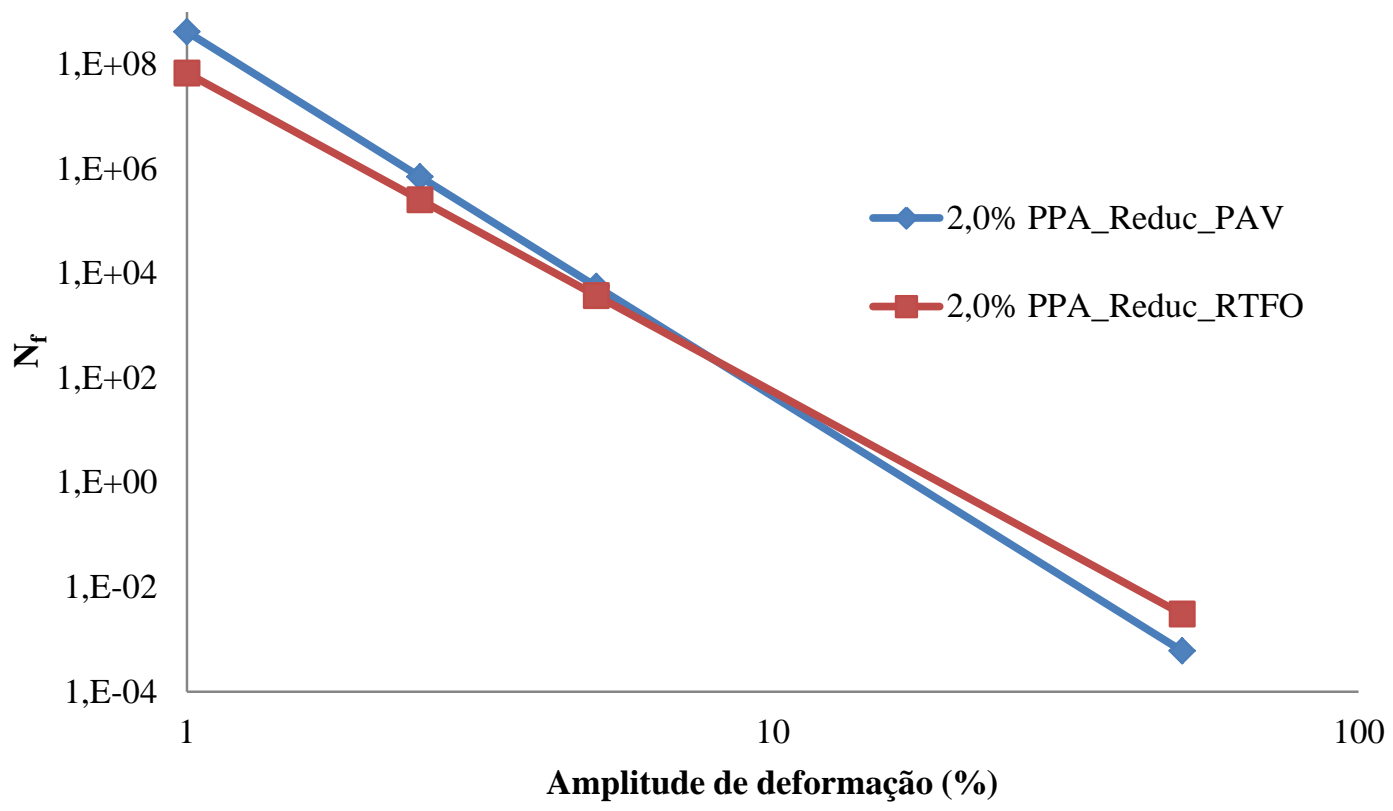

Figura 6.31 - Efeito do envelhecimento na variação do número de ciclos na ruptura em função da amplitude de deformação para o REDUC + 2,0\% PPA, a $25^{\circ} \mathrm{C}$

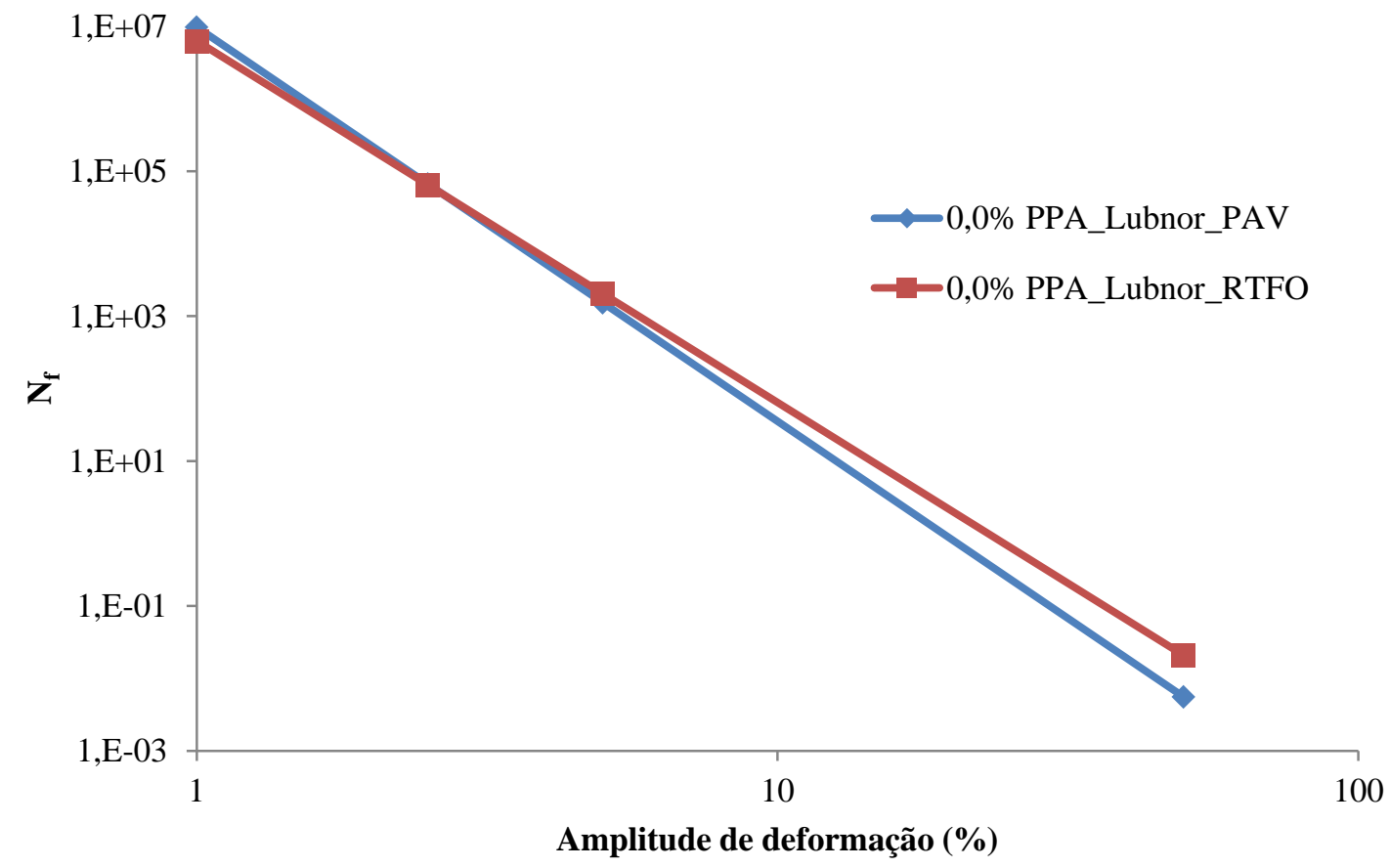

Figura 6.32 - Efeito do envelhecimento na variação do número de ciclos na ruptura em função da amplitude de deformação para o Lubnor puro, a $35^{\circ} \mathrm{C}$ 


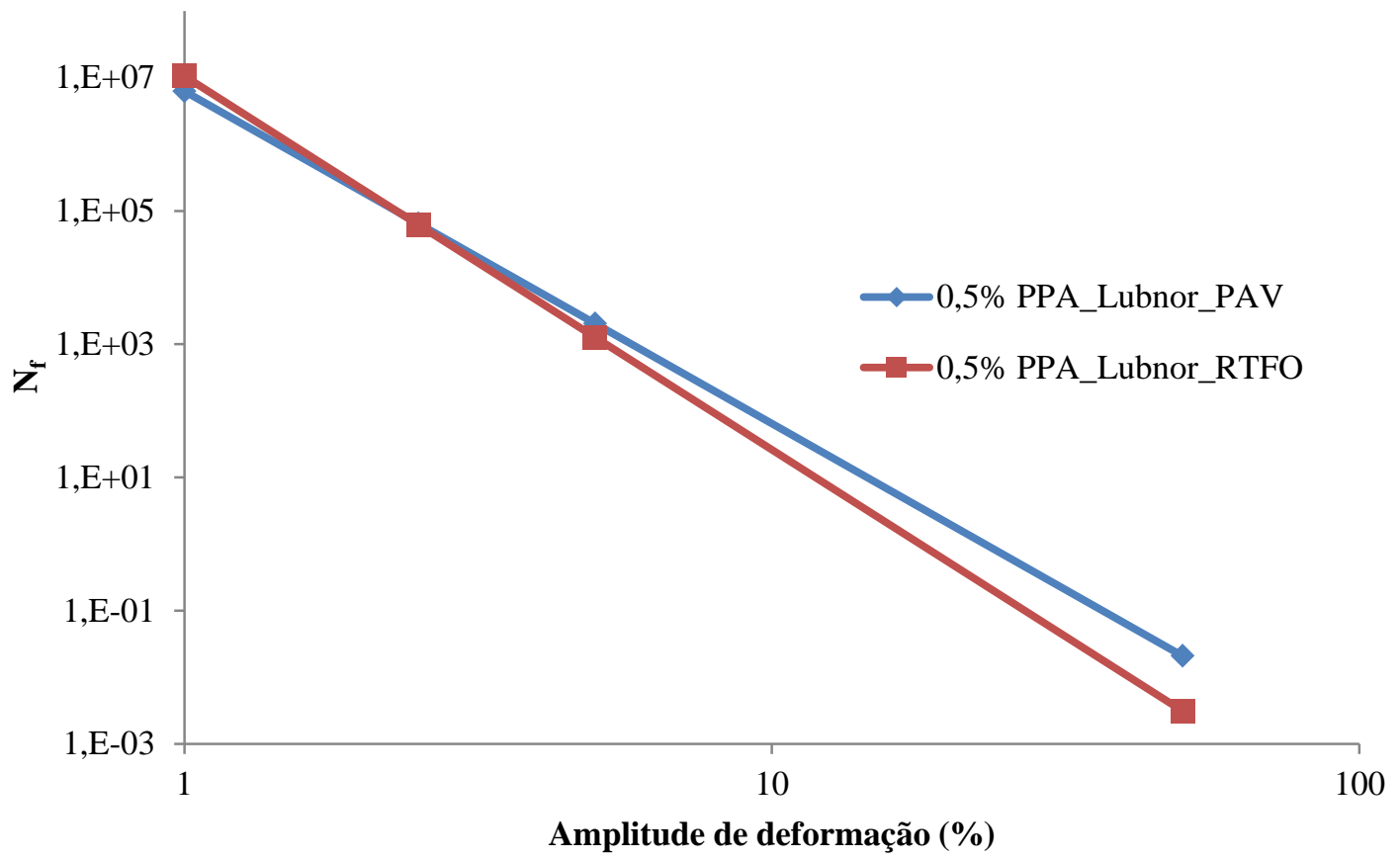

Figura 6.33 - Efeito do envelhecimento na variação do número de ciclos na ruptura em função da amplitude de deformação para o Lubnor $+0,5 \%$ PPA, a $35^{\circ} \mathrm{C}$

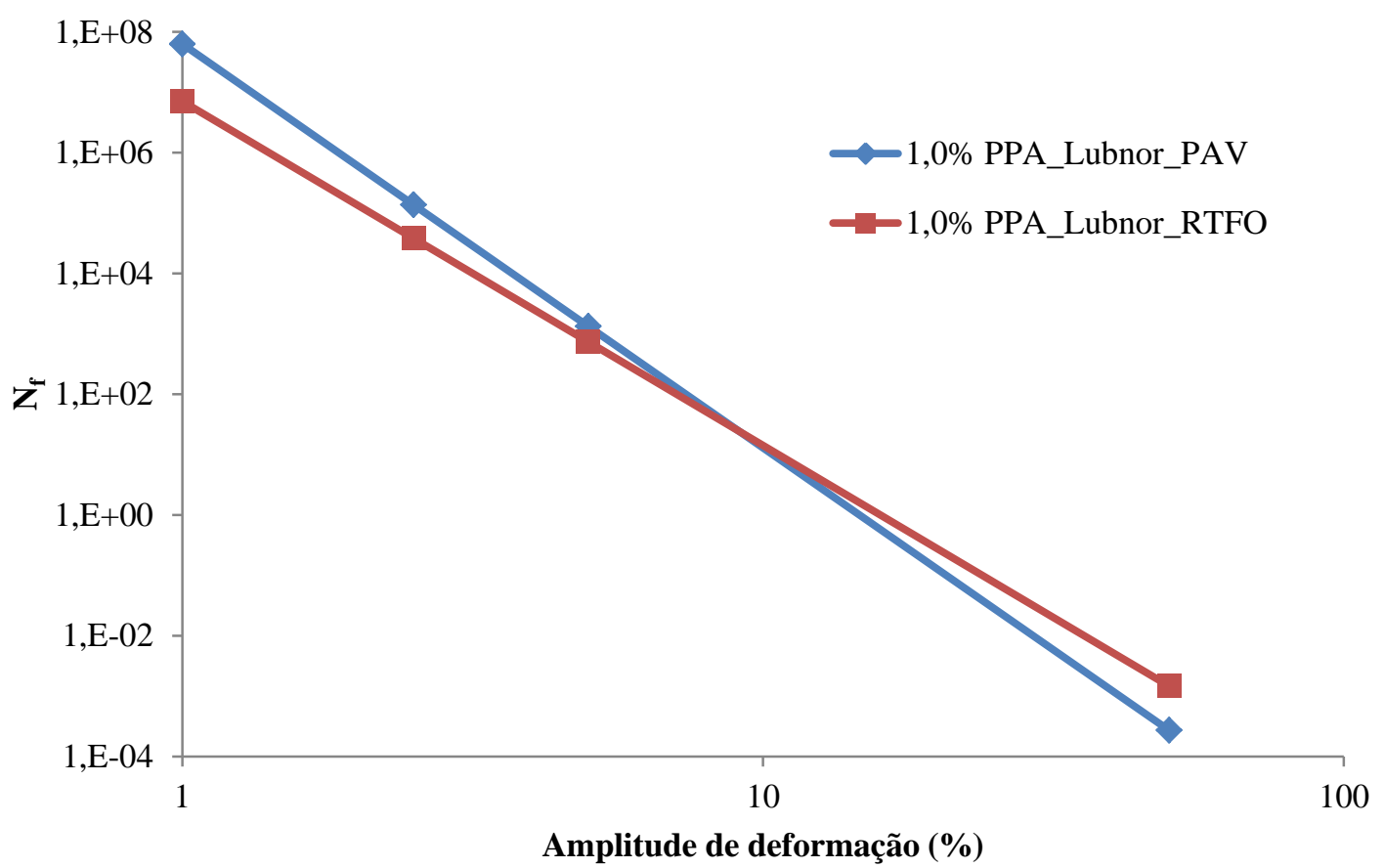

Figura 6.34- Efeito do envelhecimento na variação do número de ciclos na ruptura em função da amplitude de deformação para o Lubnor $+1,0 \%$ PPA, a $35^{\circ} \mathrm{C}$ 




Figura 6.35 - Efeito do envelhecimento na variação do número de ciclos na ruptura em função da amplitude de deformação para o Lubnor $+1,5 \% \mathrm{PPA}$, a $35^{\circ} \mathrm{C}$

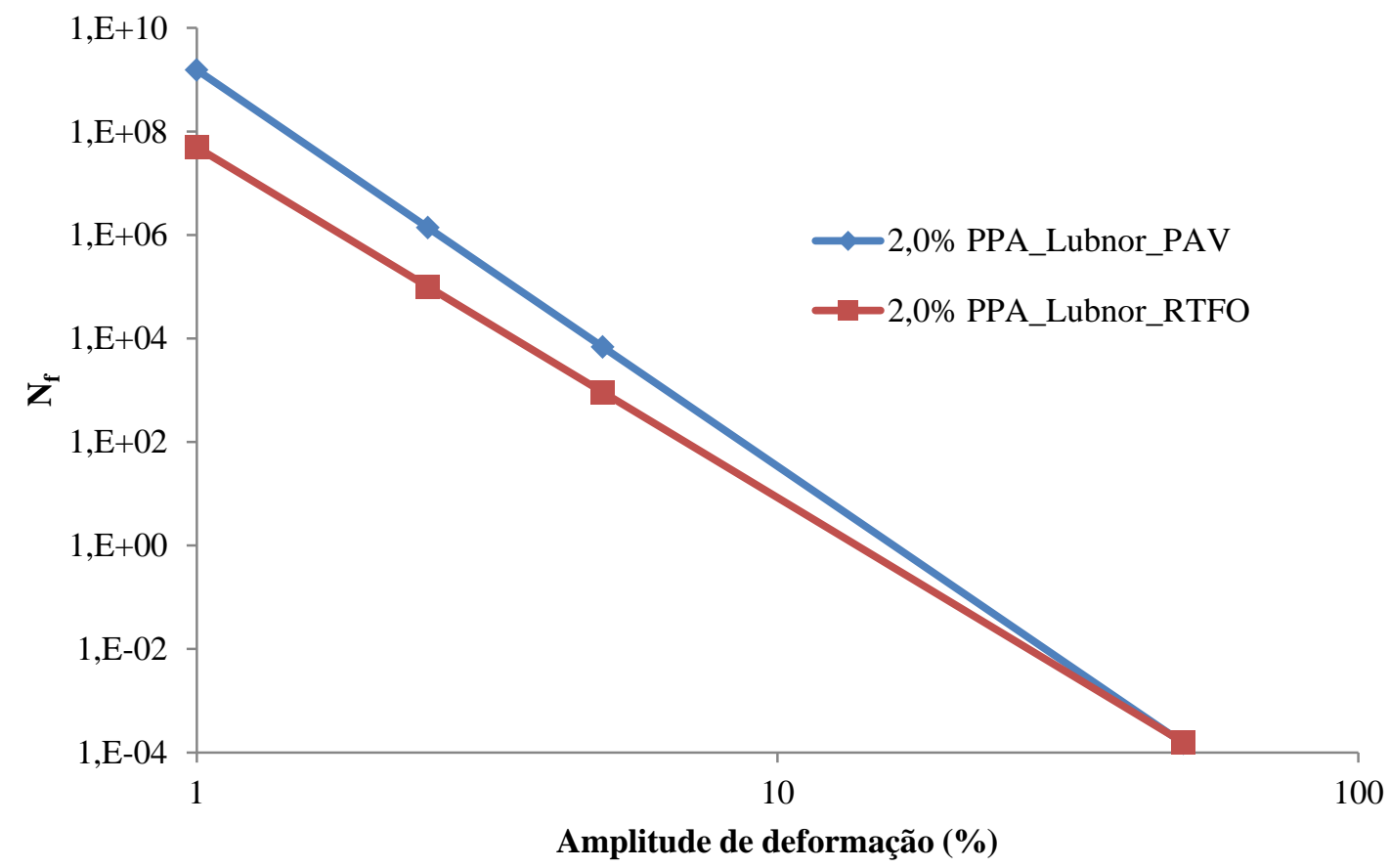

Figura 6.36 - Efeito do envelhecimento na variação do número de ciclos na ruptura em função da amplitude de deformação para o Lubnor $+2,0 \% \mathrm{PPA}$, a $35^{\circ} \mathrm{C}$ 


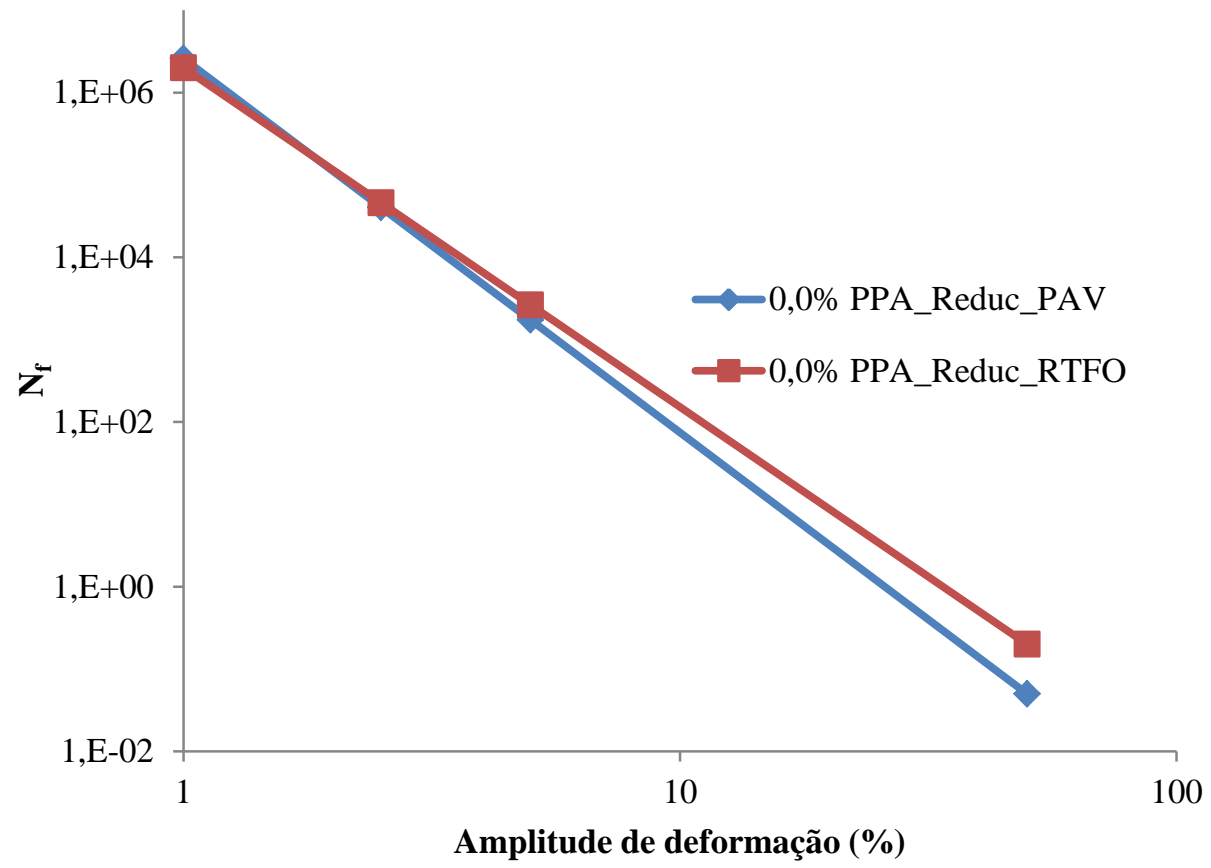

Figura 6.37 - Efeito do envelhecimento na variação do número de ciclos na ruptura em função da amplitude de deformação para o Reduc puro, a $35^{\circ} \mathrm{C}$

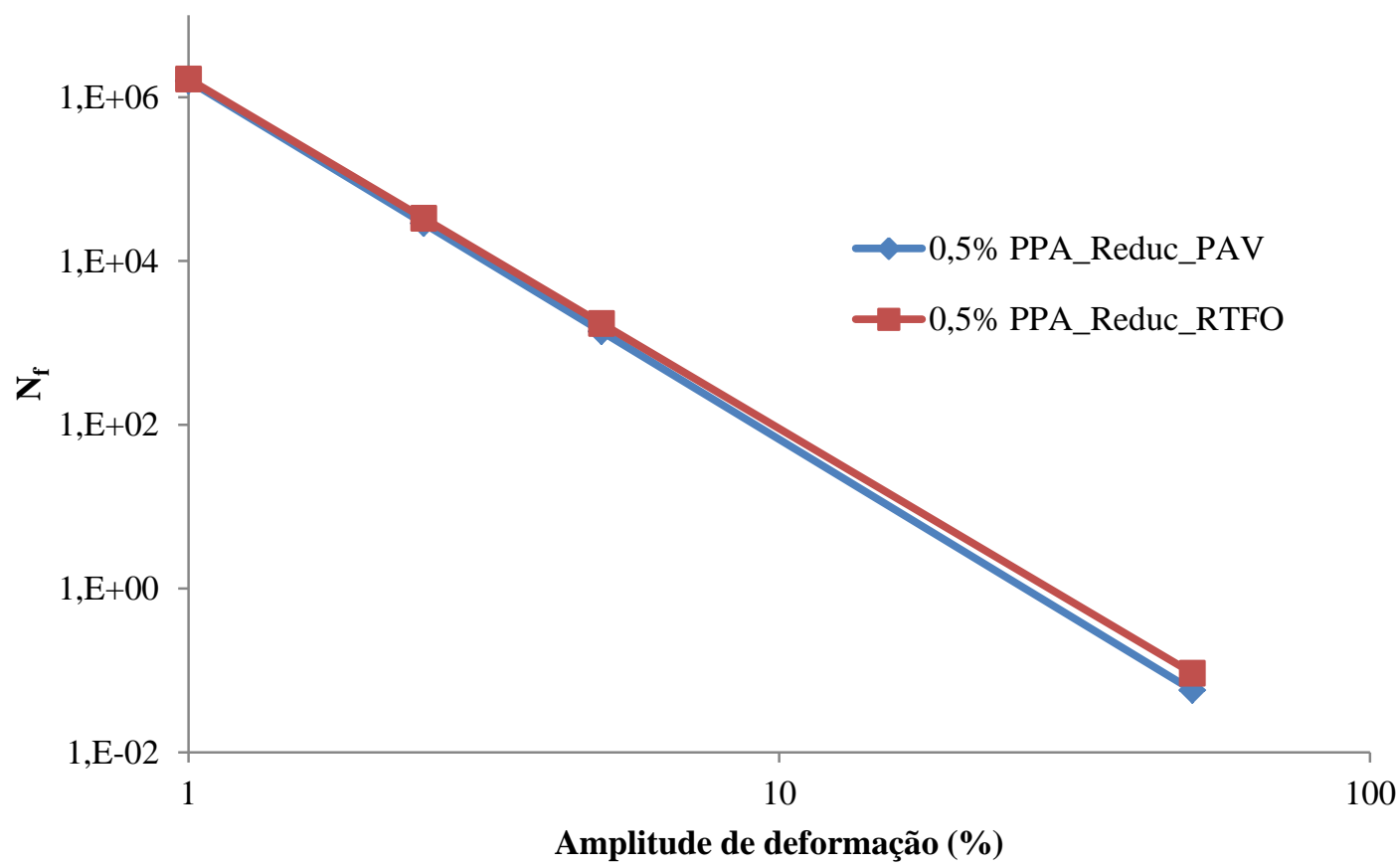

Figura 6.38 - Efeito do envelhecimento na variação do número de ciclos na ruptura em função da amplitude de deformação para o Reduc $+0,5 \%$ PPA, a $35^{\circ} \mathrm{C}$ 


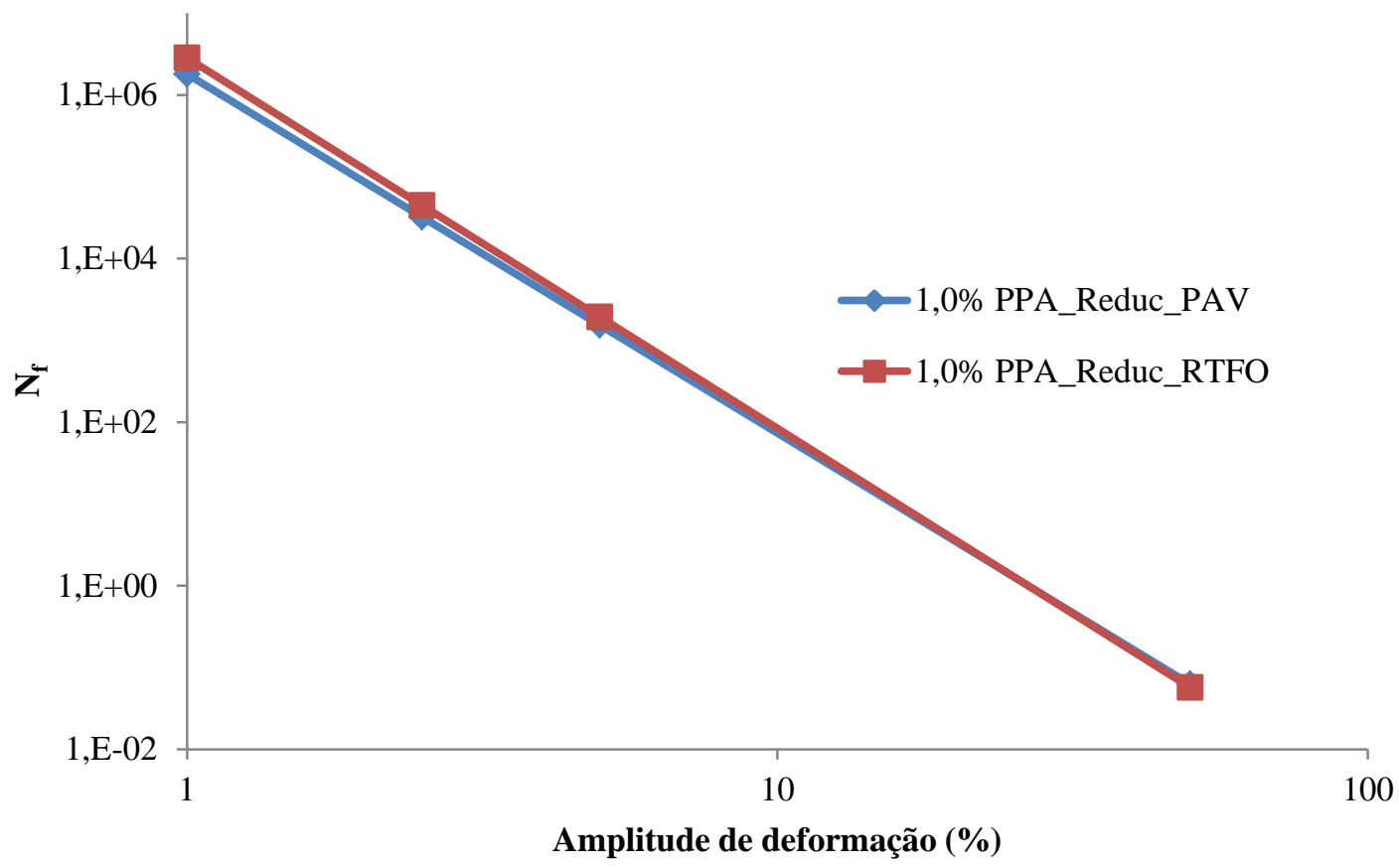

Figura 6.39 - Efeito do envelhecimento na variação do número de ciclos na ruptura em função da amplitude de deformação para o Reduc $+1,0 \% \mathrm{PPA}, \mathrm{a} 35^{\circ} \mathrm{C}$

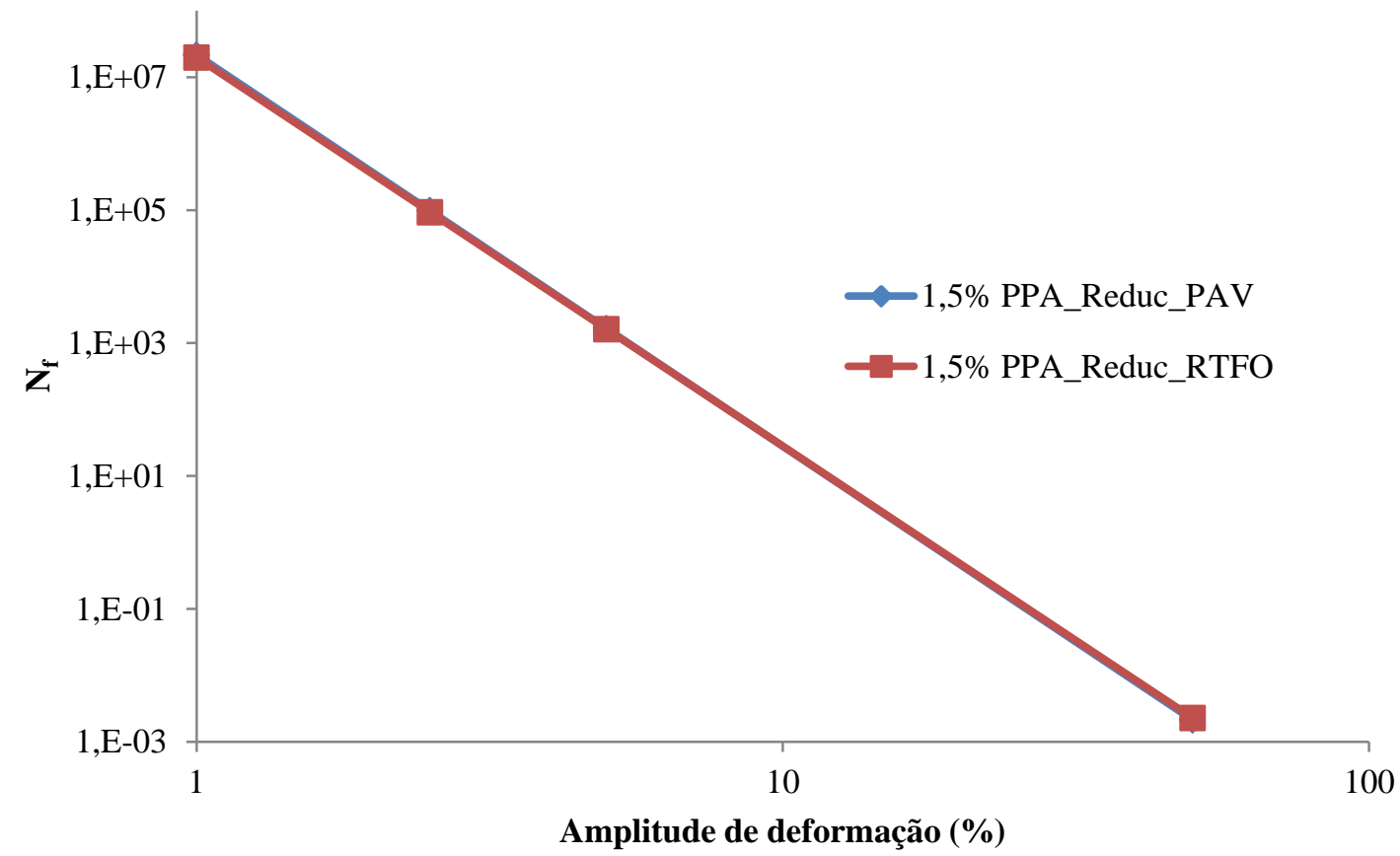

Figura 6.40 - Efeito do envelhecimento na variação do número de ciclos na ruptura em função da amplitude de deformação para o Reduc $+1,5 \% \mathrm{PPA}$, a $35^{\circ} \mathrm{C}$ 


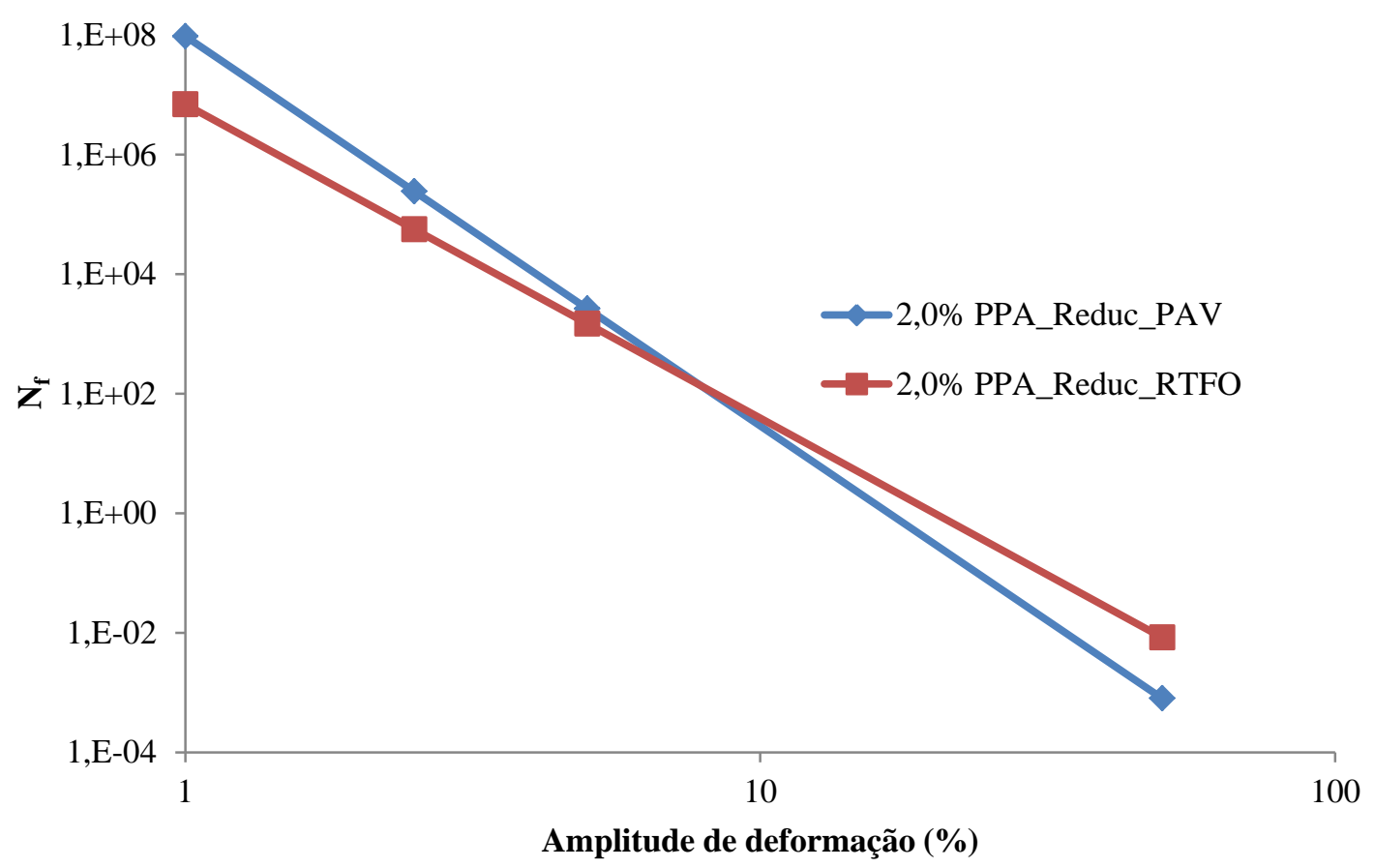

Figura 6.41 - Efeito do envelhecimento na variação do número de ciclos na ruptura em função da amplitude de deformação para o Reduc $+2,0 \%$ PPA, a $35^{\circ} \mathrm{C}$

Como visto anteriormente, o envelhecimento termo-oxidativo é benéfico à tolerância à fadiga dos ligantes asfálticos quando analisada por meio do comprimento da trinca na ruptura $\left(a_{f}\right.$ ). Quando se comparam os valores de $a_{f}$ e de $N_{f}$ (obtidos dos modelos de fadiga mostrados anteriormente), observa-se uma correspondência entre os resultados na faixa de pequenas deformações. Esta informação é importante, visto que o efeito do envelhecimento sobre o parâmetro $a_{f}$ contraria o efeito amplamente reconhecido de que o envelhecimento é prejudicial à fadiga. Os resultados de $\mathrm{a}_{\mathrm{f}}$ obtidos anteriormente indicam que o envelhecimento favorece a resistência à fadiga, na medida em que proporciona aumento dos valores de $\mathrm{a}_{\mathrm{f}}$. Esta conclusão seria válida, então, apenas para pequenas deformações. De acordo com as Figuras de 6.22 a 6.41, o envelhecimento oxidativo se mostra prejudicial à resistência à fadiga apenas para grandes deformações, concordando com o senso comum. 


\section{CAPÍTULO 7. CONCLUSÕES E SUGESTÕES DE PESQUISA}

Esta pesquisa teve como principal objetivo avaliar os efeitos do teor de ácido polifosfórico $(0,0,0,5,1,0,1,5$ e 2,0\%) em ligantes asfálticos de diferentes fontes (LUBNOR e REDUC), de penetração 50/70 e graus de desempenho diferentes (PG 70-xx e 64-xx, respectivamente), considerando a influência da composição química dos ligantes asfálticos nos efeitos causada pelo PPA. As amostras foram avaliadas em três níveis de envelhecimento: virgem, curto prazo (RTFOT) e longo prazo (PAV). O programa experimental contemplou um total de 10 ligantes asfálticos: dois ligantes asfálticos puros (LUBNOR e REDUC), quatro ligantes asfálticos da LUBNOR modificados por diferentes teores de PPA e quatro ligantes asfálticos da REDUC modificados por diferentes teores de PPA. Os ensaios realizados foram: cromatografia de camada fina, viscosidade rotacional, determinação da temperatura alta do grau de desempenho, varredura de frequência (para construção de curvas-mestre), fluência e recuperação (MSCR) e ensaio acelerado de fadiga em ligantes asfálticos (LAS).

\section{Composição química}

O efeito da adição do PPA sobre a composição química dos ligantes puros foi estudado por TLC-FID. O índice de instabilidade coloidal $\left(\mathrm{I}_{\mathrm{c}}\right)$ das amostras foi calculado a partir dos valores médios das quatro frações do ligante asfáltico (saturados, aromáticos, resinas e asfaltenos), a fim de caracterizar o ligante asfáltico no tipo SOL ou em tipo GEL. Considerando os materiais utilizados, os teores de PPA empregados e as condições experimentais adotadas, é possível concluir que:

- os ligantes asfálticos apresentam composições químicas muito distintas em termos das frações SARA e, por esta razão, reagem de maneira diferente à adição de PPA;

- o LUBNOR apresenta comportamento tipo GEL (Ic > 0,5), sendo associado a um material mais estruturado, mais elástico, mais resistentes à aplicação de carga e mais susceptível ao envelhecimento termo-oxidativo; o REDUC apresenta comportamento tipo SOL-GEL $(0,1>$ Ic > 0,5), sendo associado a um material menos resistente à aplicação de carga e menos susceptível ao envelhecimento termo-oxidativo; o REDUC apresenta, portanto, maior potencial de acúmulo de deformação permanente e é menos sensível ao envelhecimento (tais observações foram constatadas por meio dos resultados de compliância não-recuperável e pela variação na rigidez em função do envelhecimento); 
- o índice de instabilidade coloidal do LUBNOR diminui com a adição de PPA, tornando o ligante asfáltico mais estável, ao passo que o índice de instabilidade coloidal do REDUC aumenta com a adição de PPA, aproximando o comportamento do ligante asfáltico da REDUC ao comportamento tipo GEL;

- dois mecanismos decorrentes da adição de PPA parecem ser predominantes em cada caso: (1) um mecanismo que induz a agregação dos asfaltenos, que pode ocorrer por meio de uma associação intermolecular, ou (2) um mecanismo que levaria a uma dispersão dos asfaltenos; assim sendo, os dados apresentados sugerem que o ligante asfáltico da REDUC quando modificado com PPA formaria, predominantemente, associações intermoleculares, enquanto que a dispersão dos asfaltenos seria preferencial no caso da adição de PPA ao ligante asfáltico da LUBNOR; as características diversas apresentadas pelos dois ligantes são devidas às proporções relativas das frações SARA particularmente, dos teores de asfaltenos e de resinas em cada caso;

- os mecanismos predominantes decorrentes da adição de PPA são diferente para cada ligante asfáltico, no entanto os cálculos das massas molares e das transição vítreas são necessários para deduções mais precisas acerca do mecanismo.

\section{Temperatura alta do grau de desempenho}

O grau de desempenho dos ligantes asfálticos foi determinado com base apenas nas amostras virgens, de acordo com a Tabela 3 da AASHTO M 320-10. Considerando os materiais utilizados, os teores de PPA empregados e as condições experimentais adotadas, pode-se concluir que:

- a adição do PPA na faixa de 0,0 até 2,0\% aumenta a temperatura alta do PG das amostras com diferentes intensidades, dependendo do tipo de ligante asfáltico de base;

- para elevar a temperatura alta do PG em um nível, é necessário adicionar 0,35\% de PPA no CAP da LUBNOR (de PG 70 para 76) e 0,30\% de PPA no CAP da REDUC (de 64 para 70); para elevar a temperatura alta do $\mathrm{PG}$ em dois níveis, é necessário adicionar 1,05\% de PPA no CAP da LUBNOR (de PG 70 para 82) e 1,55\% de PPA no CAP da REDUC (de 64 para 76); para elevar a temperatura alta do PG em três níveis, é necessário adicionar 1,45\% de PPA no CAP da LUBNOR (de PG 70 para 88) e 2,00\% de PPA no CAP da REDUC (de 64 para 82); 
- o CAP da LUBNOR se mostrou mais sensível à adição de PPA, exigindo menores teores de PPA para aumentar a temperatura alta do PG; o LUBNOR se mostra mais adequado para modificação com PPA, uma vez que exige menor consumo de PPA para obter graus mais elevados de desempenho.

\section{Viscosidade e temperaturas de usinagem e compactação}

- Os ensaios de viscosidade rotacional foram realizados segundo a ASTM D 4402, utilizando o viscosímetro Brookfield, nas temperaturas de $135,143,150,164$ e $177^{\circ} \mathrm{C}$, sendo ensaiadas apenas as amostras virgens. Considerando os materiais utilizados, os teores de PPA empregados e as condições experimentais adotadas, as principais conclusões são:

- a viscosidade do ligante asfáltico aumenta com o aumento do teor de PPA, no entanto, nenhum dos ligantes asfálticos modificados ultrapassa o limite de viscosidade de $3 \mathrm{~Pa}$.s a $135^{\circ} \mathrm{C}$ recomendado pela especificação Superpave, mesmo para os teores mais elevados de PPA;

- como consequência do aumento da viscosidade dos ligantes asfálticos com a adição de PPA, as temperaturas de usinagem e compactação também aumentam;

- as temperaturas de usinagem e de compactação do LUBNOR modificado com 1,5 e 2,0\% de PPA são muito elevadas, prejudicando a trabalhabilidade do ligante asfáltico, além de aumentar o consumo de energia necessário para atingir as temperaturas de usinagem e de compactação e de aumentar a liberação de voláteis prejudiciais à saúde; tais restrições podem inviabilizar a utilização de teores altos de PPA para modificar este ligante asfáltico;

- a diferença entre as temperaturas de usinagem e de compactação das formulações LUBNOR + 1,5\% PPA e LUBNOR + 2,0\% PPA é muito pequena, logo a adição de teores de PPA maiores que 1,5\% ao LUBNOR não é recomendada;

- no que se refere à viscosidade, o LUBNOR é mais sensível à adição de PPA para proporções de PPA mais baixas (até 1,5\%) e o REDUC é mais sensível para as proporções de PPA mais altas. 


\section{Rigidez e elasticidade (monitoradas em regime oscilatório)}

Os resultados de rigidez e elasticidade dos ligantes asfálticos puros e modificados foram obtidos por meio do ensaio de varredura de frequência e foram analisados por meio de curvas-mestre, por meio das quais pôde-se observar o comportamento reológico dos ligantes asfálticos em função da frequência de carregamento. Considerando os materiais utilizados, os teores de PPA empregados e as condições experimentais adotadas, as análises das curvasmestre permitem concluir que:

- a adição de PPA provoca aumento na rigidez, evidenciado pelo aumento de $\mathrm{G}^{*}$, e na elasticidade, evidenciado pela diminuição de $\delta$;

- o envelhecimento termo-oxidativo provoca aumento na rigidez, evidenciado pelo aumento de $\mathrm{G}^{*}$, e na elasticidade, evidenciado pela diminuição de $\delta$;

- o efeito enrijecedor do PPA é mais expressivo nas frequências baixas (correspondentes a temperaturas altas; nas frequências altas (correspondentes a temperaturas baixas), a adição de PPA não provocou variações na rigidez das amostras preparadas com o REDUC e provocou redução na rigidez do LUBNOR;

- o efeito do PPA é mais expressivo para o ligante asfáltico da REDUC do que para o ligante asfáltico da LUBNOR nas três condições de envelhecimento (virgem, curto prazo - RTFO e longo prazo - PAV); mais uma vez fica evidenciado o efeito da composição química dos ligantes asfálticos na modificação com PPA;

- em termos de envelhecimento a curto prazo, o LUBNOR + 0,5\% de PPA é o mais sensível e o LUBNOR + 1,5\% de PPA é o menos sensível; o LUBNOR + 2,0\% é mais sensível ao envelhecimento do que o LUBNOR $+1,5 \%$, no entanto, é menos sensível ao envelhecimento do que o LUBNOR modificado com 1,0\% de PPA ou menos; para frequências de carregamento muito baixas (ao redor de $10^{-4} \mathrm{rad} / \mathrm{s}$ ), a adição de $0,5 \%$ de PPA reduz a sensibilidade ao envelhecimento em relação ao REDUC puro e, acima deste teor, a adição de PPA aumenta a sensibilidade do REDUC ao envelhecimento; já em frequências mais altas (em torno de $10 \mathrm{rad} / \mathrm{s}$ ), é nítido o efeito do PPA em reduzir a sensibilidade do REDUC ao envelhecimento a curto prazo, não sendo notada uma tendência clara do efeito do teor de PPA;

- em termos de envelhecimento a longo prazo, a adição de teores menores que 1,0\% aumenta a sensibilidade do LUBNOR e teores maiores que 1,0\% diminuem a sensibilidade do LUBNOR ao envelhecimento; já para o REDUC, teores mais baixos de 
PPA $(0,5 \%)$ diminuem a sensibilidade ao envelhecimento e teores mais altos $(1,0 \%$ ou mais) aumentam a sensibilidade do REDUC ao envelhecimento;

- de uma forma geral, o REDUC é menos sensível ao envelhecimento que o LUBNOR, sendo tal resultado também observado com base nos valores do índice de instabilidade coloidal (Ic);

- em termos da parcela de contribuição do ligante asfáltico sobre a resistência à deformação permanente das misturas asfálticas, avaliada por meio do parâmetro de deformação permanente $G^{*} / \operatorname{sen} \delta$ da especificação Superpave, o LUBNOR + 1,5\% de PPA é o que pode proporcionar maior aumento da resistência à deformação permanente; esta constatação também é evidenciada pelos resultados de MSCR, os quais indicaram que o LUBNOR + 1,5\% PPA apresenta o menores valores de Jnr; tanto a análise com base nos valores de $\mathrm{G}^{*} / \operatorname{sen} \delta$ quanto a baseada nos valores de Jnr indicam que, do ponto de vista da resistência à deformação permanente, a adição de teores maiores que $1,5 \%$ de PPA ao LUBNOR não é recomendada;

- já para o REDUC, a formulação com 1,5\% de PPA apresenta valores de G*/sen $\delta$ maiores que os obtidos para a formulação com 2,0\% de PPA; tal resultado não condiz com os resultados do MSCR, os quais indicam que o REDUC + 2,0\% PPA apresenta menor potencial a deformação permanente; tal divergência reforça a suspeita de que o parâmetro $\mathrm{G}^{*} / \mathrm{sen} \delta$ não representa adequadamente a resistência à deformação permanente dos ligantes asfálticos modificados;

- partindo da lógica da especificação Superpave, de que ligantes asfálticos mais moles são mais indicados para fadiga por deformação controlada, o PPA contribuiria com o aumento da resistência à fadiga da mistura asfáltica apenas nas temperaturas mais baixas $\left(4\right.$ e $\left.16^{\circ} \mathrm{C}\right)$ e se usado em teores altos, no caso do $\operatorname{REDUC}(1,5$ e $2,0 \%)$, e em qualquer teor para o LUBNOR (entre 0,5 e 2,0\%); nas temperaturas mais altas $\left(28\right.$ e $40^{\circ} \mathrm{C}$ ), a adição de PPA aumenta o parâmetro de fadiga, prejudicando a resistência à fadiga do ligante asfáltico; estes últimos resultados não concordam com os obtidos do ensaio LAS, no qual se verificou que a adição de PPA seria benéfica à resistência à fadiga nas temperaturas de 25 e $35^{\circ} \mathrm{C}$. 


\section{Ensaio de fluência e recuperação (MSCR)}

Foram monitorados o percentual de recuperação, associado à recuperação elástica, e a compliância não-recuperável, associada à deformação permanente, apenas das amostras envelhecidas a curto prazo. Foram feitas duas análises: uma na temperatura do PG do ligante asfáltico e outra na temperatura do pavimento. Considerando os materiais utilizados, os teores de PPA empregados e as condições experimentais adotadas, as principais conclusões da análise na temperatura do PG do ligante asfáltico são:

- observa-se a ocorrência de um teor ótimo de PPA para cada ligante asfáltico de base que proporciona um valor máximo de percentual de recuperação e um valor mínimo de compliância não-recuperável, sendo 1,5\% para o CAP da REDUC e 1,0\% para o CAP da LUBNOR;

- o ligante asfáltico da LUBNOR tem um maior aumento no percentual de recuperação e uma maior redução da compliância não-recuperável;

- os ligantes asfálticos modificados com os seus respectivos teores ótimos de PPA resultaram mais sensíveis à variação do nível de tensão $\left(\mathrm{J}_{\mathrm{nr} \text {,diff }}\right)$ que os seus respectivos sem PPA.

Com base na análise feita por meio da temperatura do pavimento, as seguintes conclusões foram obtidas:

- o percentual de recuperação dos ligantes asfálticos aumenta com a adição de PPA e diminuiu com o aumento da temperatura;

- o LUBNOR apresenta percentuais de recuperação mais altos que o REDUC, no entanto, a diferença entre os valores de \% R do LUBNOR e do REDUC diminui com o aumento da proporção de PPA, uma vez que o REDUC é mais sensível à adição de PPA;

- as formulações LUBNOR + 1,5\% PPA e LUBNOR + 2,0\% de PPA apresentaram valores de percentual de recuperação equivalentes em todas as temperaturas, logo, em termos de percentual de recuperação, a adição de um teor maior que $1,5 \%$ ao LUBNOR não é recomendada;

- a compliância não-recuperável diminui com o aumento do teor de PPA e aumenta com o aumento da temperatura, logo, a adição de PPA favorece a resistência à deformação permanente;

- a diferença entre os valores de $\mathrm{J}_{\mathrm{nr}}$ do LUBNOR e do REDUC diminui com o aumento do teor de PPA, uma vez que o REDUC é muito mais sensível à adição de PPA. 
Em relação ao efeito do PPA e do tipo de CAP sobre o nível de tráfego indicado para cada formulação, as seguintes conclusões merecem destaque:

- a adição de PPA ao ligante asfáltico de base permite aumentar a capacidade de tráfego do pavimento;

- para o LUBNOR, o teor de PPA máximo recomendado é de $1,0 \%$, já que este teor é suficiente para atender o tráfego extremamente pesado até a temperatura do pavimento de $76^{\circ} \mathrm{C}$; por outro lado, as formulações obtidas com o CAP REDUC não atendem a este nível de tráfego a $76^{\circ} \mathrm{C}$ nem quando é adicionado o teor de $2 \%$ de PPA; destaque-se que o LUBNOR puro já atende a um nível de tráfego mais elevado que o REDUC puro.

Em termos de sensibilidade à variação no nível de tensão $\left(\mathrm{J}_{\mathrm{nr}, \text { diff }}\right)$, pode-se destacar:

- a adição de PPA aumenta a sensibilidade dos ligantes asfálticos a variações no nível de tensão, como ocorre tipicamente com ligantes asfálticos modificados, tornando-os mais propensos a acumular deformações plásticas;

- em termos práticos, a adição de PPA aumenta a sensibilidade à variação de tensão dos ligantes asfálticos, mas este aumento não é excessivo, uma vez que os resultados não excederam o limite recomendado pela AASHTO M320-10.

\section{Ensaio acelerado de fadiga de ligantes asfálticos (LAS)}

O ensaio acelerado de fadiga foi realizado segundo o procedimento reformulado definido em Hintz (2012), no qual é determinado o comprimento da trinca na ruptura $\left(\mathrm{a}_{\mathrm{f}}\right)$ quanto maior o $a_{f}$ mais tolerante à fadiga o material é. Os parâmetros $A_{35}$ e $B$ foram determinados com base na teoria de dano viscoelástico contínuo, utilizada na análise concebida por Johnson (2010). Considerando os materiais utilizados, os teores de PPA empregados e as condições experimentais adotadas, as seguintes conclusões merecem destaque:

- de maneira geral, o ligante asfáltico se torna mais tolerante à fadiga com a adição de PPA;

- o aumento de rigidez induzido pela adição de PPA é benéfico à tolerância à fadiga dos ligantes asfálticos;

- o envelhecimento termo-oxidativo provoca um efeito positivo na tolerância à fadiga dos ligantes asfálticos, uma vez que o comprimento da trinca na ruptura é maior para os 
ligantes asfálticos envelhecidos no PAV do que para os ligantes asfálticos envelhecidos no RTFOT;

- em temperaturas mais elevadas $\left(35^{\circ} \mathrm{C}\right)$, o ligante asfáltico é mais sensível à adição de PPA, no entanto, é menos tolerante à fadiga;

- em termos do efeito da proporção de PPA, o LUBNOR é mais sensível em proporções mais baixas $(0,5 \%)$, mas o REDUC é mais sensível em proporções mais elevadas $(1,0 \%$ ou mais);

- os parâmetros $\mathrm{A}_{35}$ e $\mathrm{B}$ indicam que a adição de PPA age em direções opostas em relação ao seu impacto na tolerância à fadiga dos ligantes asfáltico: o LUBNOR apresentou valores de $\mathrm{A}_{35}$ mais elevados e valores de $\mathrm{B}$ menores quando comparado aos parâmetros $\mathrm{A}_{35}$ e B do REDUC; o LUBNOR se mostra, portanto, menos susceptível ao efeito do tempo de aplicação de carga e da temperatura e mantém alta integridade com o aumento da intensidade do dano em comparação ao REDUC; a adição de PPA tem mais efeito na variação dos parâmetros $\mathrm{A}_{35}$ e B para o LUBNOR que para o REDUC.

- os modelos de fadiga indicaram que a resistência à fadiga dos ligantes asfálticos é dependente do nível de tensão: para níveis de tensão mais baixos, quanto mais rígido for o ligante asfáltico, maior será a vida de fadiga e, nestas condições, a adição de PPA é benéfica à resistência à fadiga dos ligantes asfálticos; no entanto, para níveis de tensão mais elevados, quanto mais rígido for o ligante asfáltico, menor será a vida de fadiga e, nestas condições, o enrijecimento provocado pela adição de PPA é prejudicial à resistência à fadiga dos ligantes asfálticos;

- do ponto de vista mecanístico, a adição de PPA se mostrou favorável apenas quando o pavimento estiver sujeito a pequenas deformações (condição típica de pavimentos com comportamento deflectométrico mais próximo do rígido); pavimentos flexíveis sujeitos a grandes deformações não seriam beneficiados pela adição de PPA ao ligante asfáltico, uma vez que se verificou redução da vida de fadiga com o aumento da proporção de PPA adicionada ao ligante asfáltico;

- de uma maneira geral, o efeito do envelhecimento oxidativo na resistência à fadiga varia com o nível de tensão: para níveis de tensão mais baixos, o aumento de rigidez provocado pelo envelhecimento é benéfico à resistência à fadiga, já que aumenta o número de solicitações até que ocorra falha do material; mas para níveis de tensão mais altos, este aumento de rigidez torna-se prejudicial, pois o número de solicitações até que ocorra a falha do material diminui com o aumento do teor de PPA. 
Os resultados utilizados nesta análise servem para ilustrar que ligantes asfálticos distintos podem não se comportar da mesma forma à adição de PPA, tendo em vista que a adição de PPA foi mais expressiva para o LUBNOR em proporções baixas $(0,5 \%)$ e mais expressiva para o REDUC em proporções mais elevadas (1,0\% ou mais).

\section{Considerações finais}

O LUBNOR é um ligante asfáltico predominantemente naftênico. Segundo Orange (2004), o ácido polifosfórico tem impacto significativamente maior sobre as propriedades reológicas de ligantes asfálticos de natureza predominantemente naftênica. No entanto, foi observado que o LUBNOR é mais sensível à adição de PPA apenas para teores mais baixos (inferiores a 1,0\%), visto que as propriedades do LUBNOR + 1,5\% PPA e do LUBNOR + 2,0\% são semelhantes. Em alguns casos, a adição de 2,0\% de PPA ao LUBNOR prejudicou o percentual de recuperação em relação à adição de 1,5\% de PPA. Embora tenha sido verificado que o PPA seja capaz de promover melhorias significativas nas propriedades reológicas do LUBNOR, suspeita-se que teores altos de PPA venham a saturar este ligante asfáltico. Teores de PPA acima do teor onde ocorre a saturação da mistura LUBNOR+PPA não induzem melhorias ou podem prejudicar algumas das suas propriedades reológicas.

O REDUC é um ligante predominantemente aromático, logo, segundo Orange (2004), a adição de PPA não teria impacto tão significativo sobre as suas propriedades reológicas. No entanto, foi observado que o REDUC é mais sensível à adições de teores altos PPA. O REDUC puro apresenta propriedade reológicas inferiores ao LUBNOR puro, logo, sua resistência à deformação permanente e à fadiga são menores. No entanto, a diferença entre as propriedades reológicas do REDUC e do LUBNOR diminui com a adição de PPA, especialmente nos casos onde a adição de PPA deixa de surtir efeito nas propriedades do LUBNOR e continua promovendo melhorias nas propriedades do REDUC.

A sensibilidade dos ligantes asfálticos a adição de PPA varia com o teor de PPA adicionado e é diferente para cada propriedade. Para o grau de desempenho, o efeito da adição de PPA é mais expressivo no LUBNOR em todos os teores utilizados. Para a viscosidade, o LUBNOR é mais sensível a adição de PPA (até 1,5\%), enquanto o REDUC é mais sensível a adição de teores altos de PPA (2,0\%). Em termos de ganho de rigidez, percentual de recuperação e compliância não recuperável, o REDUC é mais sensível a adição de PPA para 
todas os teores de PPA. Em termos de fadiga, o LUBNOR é mais sensível para teores baixos de PPA $(0,5 \%)$ e o REDUC é mais sensível para teores altos de PPA (1,0\% ou mais).

O efeito da adição de PPA é claramente influenciado pela composição química dos ligantes asfálticos e o mecanismo predominante de reação entre o PPA e o ligante asfáltico varia de acordo com as frações SARA do ligante asfáltico. Com base nos valores do índice de instabilidade coloidal, que é uma ponderação das frações SARA dos ligantes asfálticos, pôdese observar que a adição de altos teores de PPA a um ligante asfáltico com alto índice de instabilidade coloidal (bem estruturado), como é o caso do LUBNOR, pode não surtir efeito tão expressivo como ocorre para ligantes asfálticos com índice de instabilidade coloidal mais baixos (como é o caso do REDUC). A adição de teores acima de 1,0\% de PPA ao LUBNOR reduz ligeiramente o índice de instabilidade coloidal ao passo que o índice de instabilidade coloidal do REDUC aumenta proporcionalmente ao teor de PPA adicionado (quando os teores de PPA são maiores que 1,0\%).

\section{Sugestões para pesquisas futuras}

Algumas sugestões de pesquisas futuras foram listadas para que se possa aumentar o conhecimento científico sobre o comportamento fluência-recuperação de ligantes asfálticos modificados. Estas sugestões de pesquisas incluem as seguintes:

- aprofundar o conhecimento da composição química dos ligantes asfálticos por meio: (a) da cromatografia de permeação em gel (cálculos das massas molares), (b) das transições vítreas, (c) de ensaios de determinação da presença de metais (possivelmente afetam o mecanismo de reação do PPA com o ligante asfáltico), (d) de análises térmicas (para determinação do comportamento térmico, da perda de massa, da energia de ativação dos processos de decomposição do ligante asfáltico, etc.) e (e) de técnicas espectrométricas (para a identificação dos principais grupos constituintes);

- utilizar ligantes asfálticos de outras fontes;

- preparar a mistura ligante + PPA com diferentes condições de processamento (tempo de mistura e temperatura);

- adicionar outros níveis de tensão às etapas do ensaio MSCR, de modo que a dependência dos ligantes asfálticos ao nível de tensão possa ser visualizada; 
- realizar o ensaio LAS em temperaturas mais baixas, de modo a verificar o efeito da adição de PPA sobre a tolerância à fadiga dos ligantes asfálticos em condições mais críticas em termos da rigidez do ligante asfáltico de base. 


\section{REFERÊNCIAS BIBLIOGRÁFICAS}

ABADIE, C. e D’ANGELO, J. A., (2012) Louisiana Approach to Binder Modification. Transportation Research Circular E-C160, 2012; p.151.

ANDERSON, M. et al. (2010) MSCR: a better tool for characterizing high temperature performance properties. Asphalt; 25(2): 15-16.18.21-3.

ANDERSON, D. A.; KENNEDY, T. W. (1993). Development of SHRP binder specification. Association of Asphalt Paving Technologists, v.62, p.481-507.

ANDERSON, D. A. et al. (1991). Physical properties of asphalt cement and the development of performance-related specifications. Association of Asphalt Paving Technologists, v.60, p.437-456.

ANDERSON, D. A. et al. (2001) Evaluation of fatigue criteria for asphalt binders. Transportation Research Record, No.1766, p.48-55.

ARNOLD, T. S. et al. (2012) Use of Phosphoric Acid as Modifier for Hot-Mix Asphalt. Transportation Research Circular E-C160, 2012; p.40-51.

ASPHALT INSTITUTE (2010a) Guidance on the use of the MSCR test with the AASHTO M320 specification. Asphalt Institute Guidance Document.

ASPHALT INSTITUTE (2010b) Implementation of the multiple stress creep recovery test and specification. Asphalt Institute Guidance Document.

BAHIA, H.; ANDERSON, R. (1995). Strategic highway research program binder rheological parameters: background and comparison with conventional properties. Transportation Research Record, Washington, n.1488, p.32-39.

BAHIA, H. U. et al. (2001) Characterization of Modified Asphalt Binders in Superpave Mix Design, NCHRP Report 459. Washington D.C.: National Cooperative Highway Research Program.

BAUMGARDNER, G. L. (2012) Why and How of Polyphosphoric acid Modification. An Industry Perspective. Transportation Research Circular E-C160, p.14-26.

BAUMGARDNER, G. L. et al. (2005) Polyphosphoric acid modified asphalt: proposed mechanisms. Journal of the Association of Asphalt Paving Technologists, v.74, p.283-305.

BERNNET, T.; MARTIN, J. V. (2012) Polyphosphoric Acid in Combination with StyreneButadiene-Styrene Block Copolymer. Transportation Research Circular E-C160, p.70-85.

BOLOTIN, V. (1999) Mechanics of Fatigue. CRC Mechanical Engineering Series, Editor Frank A. Kulachi, University of Minnesota, Minneapolis.

BONEMAZZI, F.; GIAVARINI, C. (1999) Shifting the Betumen Structure from Sol to Gel. Journal of Petroleum Science and Engineering., v.22. p.17-24. 
BRANTHAVER, J. F. et al. (1994) Binder Characterization and Evaluation - vol. 2 Chemistry, SHRP Report A-368.Washington D. C.: National Research Counc.

BRINGEL, R. M. (2007) Estudo Químico e Reológico de Ligantes Asfálticos Modificados por Polímeros e Aditivos. Dissertação de Mestrado, LMP/UFC, Fortaleza, CE.

BUNCHER, M. (2005). Polyphosphoric acid modification of asphalt. Asphalt Magazine. Fall, p.38-40.

CAO, W. et al. (2011) Experimental Study on Polyphosphoric Acid (PPA) Modified Asphalt Binders. Advanced Materials Research Vols. 152-153 p.288-294.

CHRISTENSEN, D. W.; ANDERSON, D. A. (1992(. Interpretation of dynamic mechanical test data for paving grade asphalt cements. Association of Asphalt Paving Technologists, v.61, p.67116.

CORBETT, L. W. (1969) Analytical Chemistry. 41, p.576-579.

D'ANGELO J. A. (2010) The multiple stress creep recovery (MSCR) procedure. Technical Brief prepared by the United States Department of Transportation, Federal Highway Administration.

D'ANGELO J. A. (2012) Effect of Polyphosphoric Acid on Asphalt Binder Properties. Transportation Research Circular E-C160, p.27-39.

DOMINGOS, M. D. I. (2011) Caracterização doo comportamento fluência-recuperação de ligantes asfálticos modificados virgens e envelhecidos. Tese de doutorado. Universidade de São Paulo. São Carlos, SP.

DOMINGOS, M. D. I.; FAXINA, A. L. a. (2011) Viscosidade rotacional de ligantes asfálticos modificados de mesmo grau de desempenho. In: XXV Congresso da Associação Nacional de Pesquisa e Ensino em Transportes, 2011, Belo Horizonte. XXV Congresso da Associação Nacional de Pesquisa e Ensino em Transportes, 2011.

DOMINGOS, M. D. I.; FAXINA, A. L. b. (2011) Caracterização do comportamento fluênciarecuperação de ligantes asfálticos modificados virgens e envelhecidos. In: XVI Congresso Iberolatinoamericado del Asfalto, 2011, Rio de Janeiro. XVI Congresso Iberolatinoamericado del Asfalto. v.1. p.746-757.

FAXINA, A. L; SUAREZ, D. A. A. (2011) Propiedades reológicas de ligantes asfálticos modificados vírgenes y envejecidos a corto plazo. In: 10o. Congreso Colombiano de Ingeniería de Tránsito y Transporte, 2011, Medellín. 10o. Congreso Colombiano de Ingeniería de Tránsito y Transporte.

FAXINA, A. L. (2010) Peculiaridades do comportamento reológico de ligantes asfálticos modificados de mesmo grau de desempenho. In: 40a. Reunião Anual de Pavimentação, 2010, Rio de Janeiro. 40a. Reunião Anual de Pavimentação.

FAXINA, A. L. (2011) Propriedades reológicas de ligantes asfálticos modificados virgens e envelhecidos a curto prazo. In: 17a. Reunião de Pavimentação Urbana, 2011, Porto Alegre. 17a. Reunião de Pavimentação Urbana. 
FEE, D. et al. (2010) Polyphosphoric Acid Modification of Asphalt. Journal of the Transportation Research Board., No. 2179, p.49-57.

FERNANDES, P. R. N. (2011) Avaliação do desempenho de ligante asfáltico modificado por poli (ácido fosfórico) (PPA) e efeitos da adição do líquido da casca da castanha de caju (LCC). Dissertação de mestrado. Universidade Federal do Ceará. Fortaleza, CE.

FILIPPIS, P. et al. (1995) Improving the ageing resistance of straight-run bitumens by addition of phosphorus compounds. Fuel. Vol. 74. No 6. p.836-841.

GAESTEL,C. et al. (1971) Contribution à la Connaissance des Proprietés des Bitumes Routiers. Bull Laboratoire des Ponts e Chaussés., v. 466, p.85-97.

GIAVARINI, C. et al. (2000). Macrostructure and rheological properties of chemically modified residues and bitumens. Energy and Fuels, v.14, p.495-502.

GIAVARINI, C. et al. (1996) Production of stable polyphopylene-modified bitumens, Fuel Vol. 75, n 6, p.681-186.

GRANDE, W. R. (2011) Efeitos da ca hidratada e do ácido polifosfórico nas propriedades mecânicas e suscetibilidade à umidade de misturas asfálticas densas. Universidade de São Paulo. São Carlos, SP.

HARVEY, J.; TSAI, B. W. (1997) Long-Term Oven-Aging Effects on Fatigue and Initial Stiffness of Asphalt Concrete. Transportation Research Record: Journal of the Transportation Research Board, No. 1590, p.89-98.

HINTZ, C. (2012) Understanding Mechanisms Leading to Asphalt Binder Fatigue. Ph.D Thesis. University of Wisconsin - Madison, Madison.

HINTZ, C. et al. (2011) Effect of Oxidative Aging on Binder Fatigue Peformance. Journal of the Association of Asphalt Paving Technologists, p.527-547.

HUANG S. et al. (2011) Rheological and Chemical Properties of Hydrated Lime and Polyphosphoric Acid-Modified Asphalt with Long-Term Aging. Journal of Materials in Civil Engeneering. p.628-637.

HUANG, S. et al. (2008) Long Term Aging Characteristics of Polyphosphoric Acid Modified Asphalts, Transportation Research Board.

JOHNSON, C. M. (2010) Estimating Asphalt Binder Fatigue Resistance using an Accelerated Test Method. Ph.D Thesis. University of Wisconsin - Madison, Madison.

KODRAT, I. et al. (2007). Comparison of polyphosphoric acid-modified asphalt binders with straight and polymer-modified materials. Transportation Research Record. Washington, n. 1988, p.47-55.

LEITE, L. F. et al. (2004). Efeito do Ácido Polifosfórico no Desempenho dos Ligantes Rodoviários. Panorama Nacional da Pesquisa em Transportes, ANPET, Rio de Janeiro, RJ, v. 1, p.40-51. 
LESUEUR, D. (2009) The colloidal structure of bitumen: Consequences on the rheology and on the mechanisms of bitumen modification. Advances in Colloid and Interface Sicence V. 145. p.42-82.

MALDONADO, R.; FEE, D. (2008) Bitumen modification with polyphosphoric acid, $4^{\text {th }}$ Euroasphalt \& Eurobitumen Congress, Copenhagen, Dinamarca.

MALDONADO, R. et al. (2012) The Effect of Processing Conditions on the Performance of Hibrid (SBS+PPA) Modified Binders. $5^{\text {th }}$ Eurasphalt \& Eurobitume Congress, Istambul.

MARTIN, J. V.; BAUMGARDNER, G. L. (2006) A New Method to Produce Polymer Modified Asphalt with Crumb Rubber and Polyphosphoric Acid: Combining Recycling and Performance, Asphalt Rubber Conference, p.903-930.

MARTONO, W. et al. (2007) Effect of testing geometry on measuring fatigue of asphalt binders and mastics. Journal of Materials in Civil Engineering, Vol.19, No.9, p.746-752.

MASSON, F. J. (2008) Brief Review of the Chemistry of Polyphosphoric Acid (PPA) and Bitumen. Energy \& Fuel. V. 22. No 4. p.2637-2640.

MORALES, M. G. et al. (2004) Viscous Properties and Microstructure of Recycled EVA Modified Bitumen. Fuel., v. 83, p.31-38.

ORANGE, G. et al. (2004) Chemical Modification of Bitumen throught Polyphosphoric Acid: Properties-microstructure Relationship, $3^{\text {rd }}$ Eurobitume \& Eurasphalt Congress, Viena, Austria, May 12-14, p.733-745.

POLACCO, G. et al. (2006). Relation between polymer architecture and monlinear viscoelastic behavior of modified asphalts. Current Opinion in Colloid and Interface Science, n.11, p.230-245.

SHELL. (2003) The Shell Bitumen Handbook., 5. ed. Cambridge.

SHENOY, A. (2001). Refinement of the Superpave specification parameter for performance grading of asphalt. Journal of Transportation Engineering. New York, v. 127, n. 5, p.357-362.

SHENOY, A. (2002). "Fatigue testing and evaluation of asphalt binders using the dynamic shear rheometer." Journal of Testing and Evaluation, Vol.30, No.4, p.303-312.

SHULGA, O. et al. (2012) Aplication of Polyphosphoric Acid for HMA Modification. US and European Experience. 5th Eurasphalt \& Eurobitume Congress, Istanbul, June 13 - 15th.

VALLERGA, B. et al. (1972) Effect of Asphalt Aging on the Fatigue Properties of Asphalt Concrete. Third International Conference on Asphalt Pavements, Ann Arbor, Michigan, p.595-617.

WESTERMAN, G. R.; D’ANGELO, J. A. (2012) Modified Asphalt Cement Use in Arkansas. Transportation Research Circular E-C160, 2012; p.108 